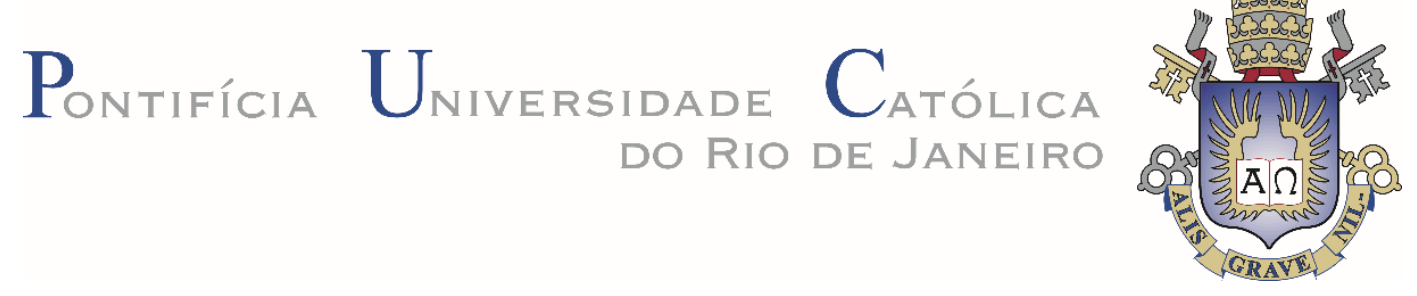

Kristian Andrade Paz de la Torre

\title{
Aplicação de lignina no solo para obtenção de benefícios ambientais
}

Dissertação apresentada como requisito parcial para obtenção do grau de Mestre pelo Programa de PósGraduação em Engenharia de Materiais e de Processos Químicos e Metalúrgicos do Departamento de Engenharia Química e de Materiais da PUC-Rio.

Orientador: Prof. Eduardo de Albuquerque Brocchi

Rio de Janeiro

Setembro de 2017 


\section{Kristian Andrade Paz de la Torre}

\section{Aplicação de lignina no solo para obtenção de benefícios ambientais}

Dissertação apresentada como requisito parcial para obtenção do grau de Mestre pelo Programa de PósGraduação em Engenharia de Materiais e de Processos Químicos e Metalúrgicos do Departamento de Engenharia Química e de Materiais da PUC-Rio. Aprovada pela Comissão Examinadora abaixo assinada.

Prof. Eduardo de Albuquerque Brocchi

Orientador e Presidente

Departamento de Engenharia Química e de Materiais - PUC-Rio

Prof. Raul de Almeida Nunes

Departamento de Engenharia Química e de Materiais - PUC-Rio

Dr. David Vilas Boas de Campos

Empresa Brasileira de Pesquisa Agropecuária - Embrapa Solos

Prof. Marcio da Silveira Carvalho Coordenador Setorial do Centro Técnico Científico - PUC-Rio

Rio de Janeiro, 25 de setembro de 2017 
Todos os direitos reservados. É proibida a reprodução total ou parcial do trabalho sem autorização da universidade, do autor e do orientador.

\section{Kristian Andrade Paz de la Torre}

Graduou-se em Engenharia Ambiental e Sanitária pela Pontifícia Universidade Católica, Rio de Janeiro, em 2013.

Ficha Catalográfica

Torre, Kristian Andrade Paz de la

Aplicação de lignina no solo para obtenção de benefícios ambientais / Kristian Andrade Paz de la Torre ; orientador: Eduardo de Albuquerque Brocchi.-2017.

147 f. : il. color. ; $30 \mathrm{~cm}$

Dissertação (mestrado)-Pontifícia Universidade Católica do Rio de Janeiro, Departamento de Engenharia Química e de Materiais, 2017.

Inclui bibliografia

1. Engenharia de Materiais - Teses. 2. Engenharia Química Teses. 3. Solo. 4. Fertilidade. 5. Erosão. 6. Lignina. I. Brocchi, Eduardo de Albuquerque. II. Pontifícia Universidade Católica do Rio de Janeiro. Departamento de Engenharia Química e de Materiais. III. Título.

CDD: 620.11 


\section{Agradecimentos}

Agradeço a Deus, em primeiro lugar, pela total ajuda na feitura deste trabalho, em todas as atividades de minha carreira profissional e em todos os demais momentos de minha vida.

Agradeço também a minha mãe, Célia, e minha irmã, Bianca, pelo apoio incondicional à minha carreira.

Ao meu professor e orientador Eduardo, pela transmissão de conhecimentos durante as aulas e pela orientação na execução deste trabalho.

Aos professores Raul, Cecília e Ana Rosa, pela orientação dada.

A todos os demais professores que tive ao longo do mestrado.

Ao CNPq, pela bolsa de fomento que recebi.

À PUC-Rio, pelos auxílios concedidos.

Aos técnicos de laboratório Henrique, Josué, Amaury e demais que me auxiliaram nos experimentos.

Ao pesquisador David, pelo auxílio na escrita do trabalho e por prover experimentos cruciais para o mesmo, motivo este pelo qual também agradeço a toda a Embrapa Solos.

À empresa fabricante de celulose e ao seu engenheiro com quem fiz o contato, pelo fornecimento de material orgânico indispensável a este trabalho.

A todos os demais funcionários da PUC-Rio que contribuíram em minha carreira.

Aos meus colegas de curso, pelo apoio e companhia em diversos momentos de estudo e lazer.

Aos vários colegas de trabalho que tive ao longo de minha carreira, pelas contribuições em minha formação.

Agradeço, por fim, a todos os demais familiares, amigos e outras pessoas que, de alguma forma, contribuíram para o sucesso dessa minha jornada. 


\section{Resumo}

Torre, Kristian Andrade Paz de la; Brocchi, Eduardo de Albuquerque. Aplicação de lignina no solo para obtenção de benefícios ambientais. Rio de Janeiro, 2017. 147p. Dissertação de Mestrado - Departamento de Engenharia Química e de Materiais, Pontifícia Universidade Católica do Rio de Janeiro.

A fertilidade dos solos tem uma enorme importância para o meio ambiente, especialmente na produção de alimentos. Considerando-se isso, o presente trabalho buscou obter benefícios ambientais a partir da aplicação de um resíduo orgânico, rico em lignina, sobre o solo. Por meio dessa ação, buscou-se tornar o solo mais resistente à erosão e mais capaz de armazenar água e nutrientes. É importante citar, ainda, que o emprego de um resíduo orgânico configura um reaproveitamento de rejeito e possibilita o armazenamento de carbono. $O$ procedimento teve início, então, com a obtenção de um composto rico em lignina. Em seguida, foi feita sua oxidação. Subsequentemente, esse material foi caracterizado, por termogravimetria (TG), espectroscopia no infravermelho por transformada de Fourier (FTIR), microscopia eletrônica de varredura (MEV) e espectroscopia de raios $\mathrm{x}$ por energia dispersiva (EDS). Então, fez-se a inoculação do composto em um solo, seguida pela determinação dos limites de Atterberg e Capacidade de Troca Catiônica (CTC). Um dos resultados foi a obtenção de um composto rico em lignina a partir de bagaço de cana-de-açúcar, mas com rendimento de cerca de $10 \%$. Dando continuidade, usou-se um resíduo industrial de produção de celulose, cuja funcionalização com ácido acético apresentou o melhor rendimento. De acordo com a microscopia, o resíduo não funcionalizado exibiu notáveis rugosidade e superfície de contato, o que foi ainda otimizado pelo ácido acético. O EDS apontou a presença de carbono, oxigênio e enxofre. O FTIR indicou a existência de grupos oxigenados tanto antes quanto depois das funcionalizações. O limite de liquidez aumentou, bem como a acidez causada pelo íon hídron e a capacidade de troca de sódio, cálcio e potássio.

\section{Palavras-Chave}

Solo; fertilidade; erosão; lignina. 


\section{Abstract}

Torre, Kristian Andrade Paz de la; Brocchi, Eduardo de Albuquerque (Advisor). Application of lignin in the soil for obtaining environmental benefits. Rio de Janeiro, 2017. 147p. Dissertação de Mestrado Departamento de Engenharia Química e de Materiais, Pontifícia Universidade Católica do Rio de Janeiro.

Soil fertility is of enormous importance to the environment, especially in food production. Considering this, the present work sought to obtain environmental benefits from the application of an organic residue, rich in lignin, in the soil. Through this action, the aim was to make the soil more resistant to erosion and more capable of storing water and nutrients. It is important to mention, also, that the application of an organic residue constitutes a reuse of waste and enables the storage of carbon. The procedure then started with obtaining a lignin-rich compound. After, it's oxidation was made. Subsequently, this material was characterized by thermogravimetry (TG), Fourier transform infrared spectroscopy (FTIR), scanning electron microscopy (SEM) and dispersive energy $\mathrm{x}$-ray spectroscopy (EDS). Then, the compound was inoculated into a soil, followed by determination of the Atterberg Limits and Cation Exchange Capacity (CTC). One of the results was to obtain a lignin-rich compound from sugarcane bagasse, but with yield of about $10 \%$. Continuing, an industrial cellulose production residue was used, whose functionalization with acetic acid presented the best yield when compared to with other acids. According to the microscopy, the non-functionalized residue exhibited remarkable roughness and contact surface, which was further optimized by the acetic acid. The EDS pointed to the presence of carbon, oxygen and sulfur. The FTIR indicated the existence of oxygen groups both before and after the functionalizations. The liquidity limit increased, as well as the acidity caused by the hydron and the capacity to exchange sodium, calcium and potassium.

\section{Keywords}

Soil; fertility; erosion; lignin. 


\section{Sumário}

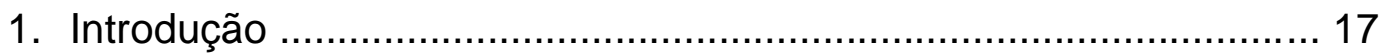

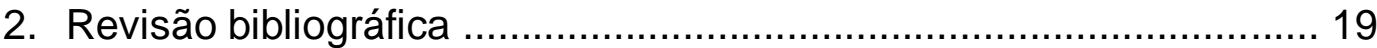

2.1. Definições de solo ............................................................ 19

2.2. Funções do solo ............................................................. 20

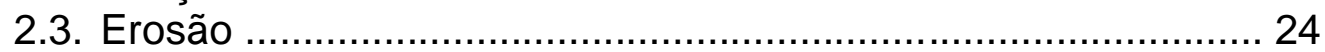

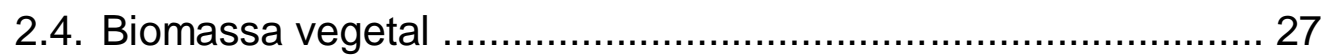

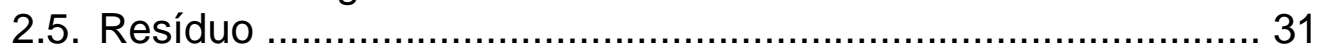

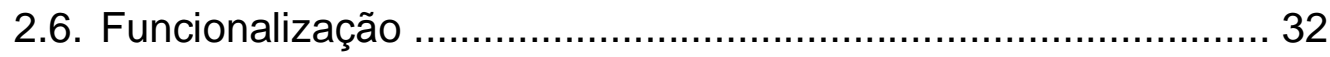

2.7. Excesso de gases com carbono na atmosfera .......................... 33

2.8. Histórico ……................................................................... 35

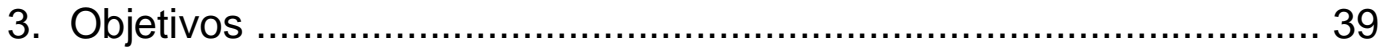

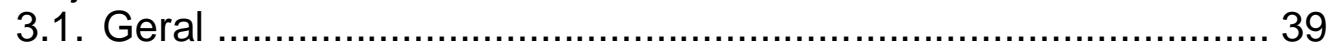

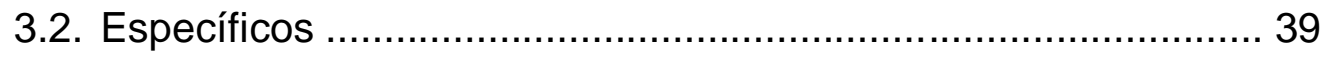

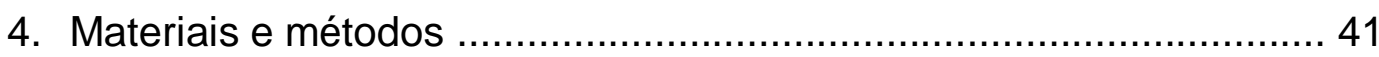

4.1. Obtenção de composto rico em lignina ................................... 41

4.2. Funcionalização do composto rico em lignina ............................ 45

4.3. Termogravimetria (TG) ………........................................... 51

4.4. Microscopia eletrônica de varredura (MEV) e Espectroscopia de Raios X por Energia Dispersiva (EDS) ............................... 52

4.5. Espectroscopia no infravermelho por transformada de Fourier (FTIR) ............................................................. 53

4.6. Caracterização mecânica do solo ........................................... 55

4.7. Capacidade de troca catiônica (CTC) ……………………....... 65

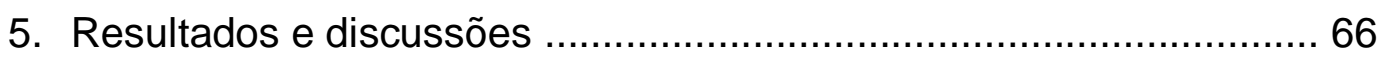

5.1. Obtenção de composto rico em lignina ………………............ 66

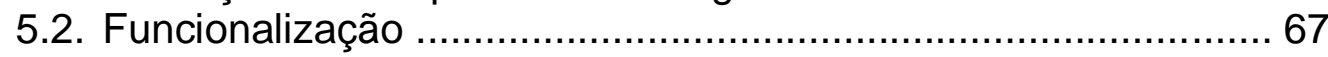

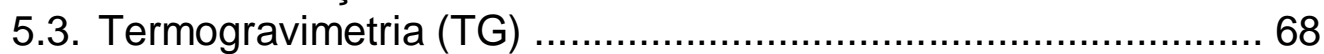

5.4. Microscopia eletrônica de varredura (MEV) e Espectroscopia de Raios X por Energia Dispersiva (EDS) ............................... 76

5.5. Espectroscopia no infravermelho por transformada de

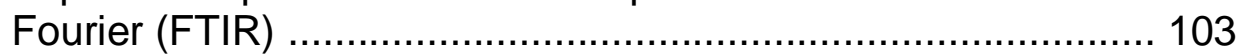

5.6. Caracterização mecânica do solo ......................................... 112

5.7. Capacidade de troca catiônica (CTC) …………………........ 125

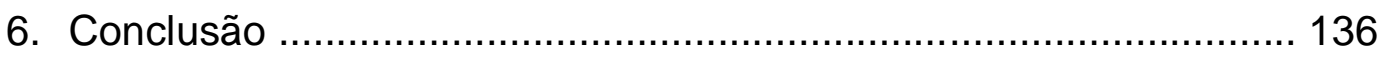

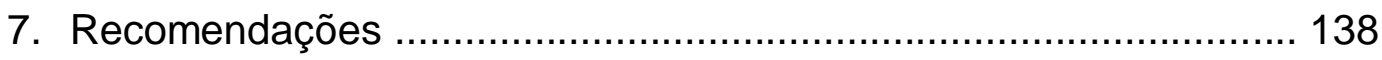

8. Referências bibliográficas ……................................................. 140

9. Apêndice - Plano de amostras ................................................. 146 


\section{Lista de figuras}

Figura 1 - llustração dos Limites de Atterberg ..................................... 27

Figura 2 - Precursores dos fenilpropanóides da lignina ........................ 28

Figura 3 - Estrutura molecular da lignina de faia .................................. 29

Figura 4 - llustração de material lignocelulósico (http://portfolio.

scistyle .com/Lignocellulose, acessado em 14/06/2016) ...................... 31

Figura 5 - Bagaço de cana envolvido por papel filtro ........................... 42

Figura 6 - Bagaço livre de extrativos reagindo com ácido sulfúrico,

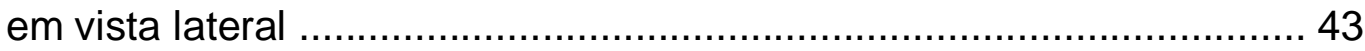

Figura 7 - Bagaço livre de extrativos reagindo com ácido sulfúrico,

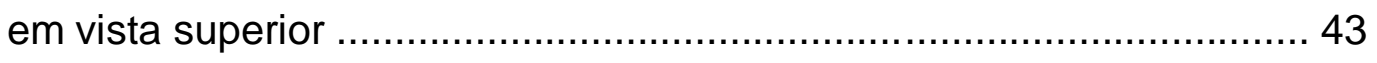

Figura 8 - Resultado da secagem do material ..................................... 44

Figura 9 - Projeção da mistura de solução ácida e resíduo ................... 46

Figura 10 - Sistema de mistura da solução ácida ao resíduo ................ 47

Figura 11 - Sistema de refluxo aplicado à mistura de lignina $\mathrm{e}$

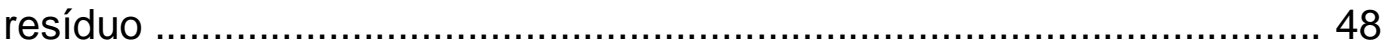

Figura 12 - Solução ao fim da centrifugação ........................................ 49

Figura 13 - Suspensão do composto sólido com água, encaminhada

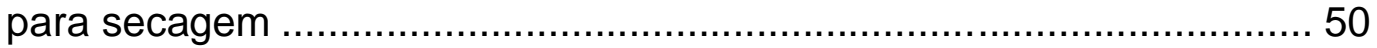

Figura 14 - Resultado da secagem ............................................. 50

Figura 15 - llustração da balança termogravimétrica da marca

Setaram, modelo Setsys Evolution (http://www.setaram.com/wp

-content/uploads/2015/01/SETSYS-Evolution-closed1-185x230.jpg, acessado em 18/07/2017) ............................................................ 51

Figura 16 - Equipamento de FTIR da marca PerkinElmer, modelo

Frontier 54

Figura 17 - Prensa para ensaio de FTIR .......................................... 54

Figura 18 - Solo após secagem em estufa, a $50^{\circ} \mathrm{C}$, durante $24 \mathrm{~h} \mathrm{..........} 56$

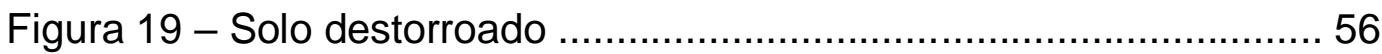

Figura 20 - Pilha de peneiras em agitador automático ........................... 58 
Figura 21 - Mistura de solo e defloculante em misturador automático ... 58

Figura 22 - Provetas no ensaio de sedimentação 58

Figura 23 - Homogeneização do solo para ensaio de limite

de plasticidade 60

Figura 24 - Ensaio de limite de plasticidade 61

Figura 25 - Ensaio de limite de liquidez

Figura 26 - Homogeneização de temperatura no ensaio de massa específica dos grãos 63

Figura 27 - Bagaço de cana-de-açúcar ampliado x120 77

Figura 28 - Bagaço de cana-de-açúcar ampliado x500 78

Figura 29 - Bagaço de cana-de-açúcar ampliado x120 em 2ª região 79

Figura 30 - Produto do processo Klason sobre o bagaço de

cana-de-açúcar ampliado X120

Figura 31 - Produto do processo Klason sobre o bagaço de cana-de-açúcar ampliado x1500

Figura 32 - Produto do processo Klason sobre o bagaço de cana-de-açúcar ampliado x1000 82

Figura 33 - Resíduo de produção de celulose ampliado x120 83

Figura 34 - Resíduo de produção de celulose ampliado x10000 84

Figura 35 - Resíduo de produção de celulose ampliado x3000 85

Figura 36 - Resíduo de produção de celulose ampliado x20000 85

Figura 37 - Resíduo de produção de celulose funcionalizado por ácido nítrico e ampliado x120 86

Figura 38 - Resíduo de produção de celulose funcionalizado por ácido nítrico e ampliado $\times 1000$

Figura 39 - Resíduo de produção de celulose funcionalizado por ácido nítrico e ampliado x10000 88

Figura 40 - Resíduo de produção de celulose funcionalizado por ácido fosfórico e ampliado $\times 120$ 89

Figura 41 - Resíduo de produção de celulose funcionalizado por ácido fosfórico e ampliado $\times 3000$ 90

Figura 42 - Resíduo de produção de celulose funcionalizado por 
ácido fosfórico e ampliado $\times 30000$

Figura 43 - Resíduo de produção de celulose funcionalizado por ácido fosfórico e ampliado x30000 em 2ª região 92

Figura 44 - Resíduo de produção de celulose funcionalizado por ácido acético e ampliado x120 93

Figura 45 - Resíduo de produção de celulose funcionalizado por ácido acético e ampliado x10000 94

Figura 46 - Resíduo de produção de celulose funcionalizado por ácido acético e ampliado $\times 1000$

Figura 47 - Resíduo de produção de celulose funcionalizado por ácido acético e ampliado $\times 1000$ em $2^{2}$ região 96

Figura 48 - Resíduo de produção de celulose funcionalizado por ácido acético e ampliado $\times 3000$

Figura 49 - Resíduo de produção de celulose funcionalizado por ácido acético e ampliado x20000 97

Figura 50 - Superfície da pastilha de resíduo de produção de celulose ampliada $\times 100$ 99 


\section{Lista de tabelas}

Tabela 1 - Resultado gravimétrico da obtenção do composto rico em lignina 66

Tabela 2 - Resultado gravimétrico da funcionalização do resíduo 67

Tabela 3 - Composição do bagaço de cana-de-açúcar interpretada a partir do termograma 69

Tabela 4 - Composição do produto do processo Klason sobre o bagaço de cana-de-açúcar interpretada a partir do termograma 71

Tabela 5 - Composição do resíduo de produção de celulose

interpretada a partir do termograma

Tabela 6 - Resultado de EDS do resíduo de produção de celulose ..... 100

Tabela 7 - Resultado de EDS do resíduo de produção de

celulose funcionalizado por ácido nítrico

Tabela 8 - Resultado de EDS do resíduo de produção de

celulose funcionalizado por ácido fosfórico

Tabela 9 - Resultado de EDS do resíduo de produção de

celulose funcionalizado por ácido acético 103

Tabela 10 - Granulometria do solo

Tabela 11 - Umidade higroscópica do solo 113

Tabela 12 - Amostra total seca 114

Tabela 13 - Peneiramento da amostra total

Tabela 14 - Peneiramento da amostra parcial 115

Tabela 15 - Sedimentação 
Tabela 16 - Massa específica dos grãos

Tabela 17 - Resumo dos limites de Atterberg das amostras de solo

com $0 \%, 1 \%, 5 \%$ e $10 \%$ de RPC

Tabela 18 - Limites de Atterberg do solo puro 118

Tabela 19 - Limite de plasticidade do solo puro 118

Tabela 20 - Limite de liquidez do solo puro 118

Tabela 21 - Coeficientes do gráfico 16

Tabela 22 - Limites de Atterberg do solo com 1\% de resíduo de

produção de celulose

Tabela 23 - Limite de plasticidade do solo com 1\% de resíduo

de produção de celulose

Tabela 24 - Limite de liquidez do solo com 1\% de resíduo de

produção de celulose 120

Tabela 25 - Coeficientes do gráfico 17

Tabela 26 - Limites de Atterberg do solo com 5\% de resíduo de

produção de celulose

Tabela 27 - Limite de plasticidade do solo com 5\% de resíduo

de produção de celulose

Tabela 28 - Limite de liquidez do solo com 1\% de resíduo de

produção de celulose 122

Tabela 29 - Coeficientes do gráfico 18 123

Tabela 30 - Limites de Atterberg do solo com 10\% de

resíduo de produção de celulose 123

Tabela 31 - Limite de plasticidade do solo com 10\% de 
resíduo de produção de celulose 123

Tabela 32 - Limite de liquidez do solo com 1\% de resíduo de

produção de celulose 124

Tabela 33 - Coeficientes do gráfico 19 124

Tabela 34 - Valores em triplicata para o cálculo da capacidade de troca catiônica das amostras de solo com 0\%, 1\%, 5\% e 10\% de RPC

Tabela 35 - Valores para o cálculo da capacidade de troca catiônica das amostras de solo com $0 \%, 1 \%, 5 \%$ e $10 \%$ de RPC 126

Tabela 36 - Percentual de cada cátion por amostra 130

Tabela 37 - Siglas do plano de amostras 140

Tabela 38 - Amostras 140

Tabela 39 - Massa total de amostras por ensaio 141 


\section{Lista de gráficos}

Gráfico 1 - Termograma do bagaço de cana-de-açúcar ....................... 69

Gráfico 2 - Termograma diferencial do bagaço de cana-de-açúcar ....... 70

Gráfico 3 - Termograma do produto do processo Klason sobre o

bagaço de cana-de-açúcar

Gráfico 4 - Termograma diferencial do produto do processo Klason

sobre o bagaço de cana-de-açúcar ..................................................... 72

Gráfico 5 - Termograma do resíduo de produção de celulose ............... 73

Gráfico 6 - Termograma diferencial do resíduo de produção de

celulose

75

Gráfico 7 - Resultado de EDS do resíduo de produção de celulose .... 100

Gráfico 8 - Resultado de EDS do resíduo de produção de celulose

funcionalizado por ácido nítrico

Gráfico 9 - Resultado de EDS do resíduo de produção de celulose funcionalizado por ácido fosfórico

Gráfico 10 - Resultado de EDS do resíduo de produção de celulose funcionalizado por ácido acético 103

Gráfico 11 - Absorbância x Comprimento de Onda da análise FTIR

do resíduo de produção de celulose 104

Gráfico 12 - Absorbância x Comprimento de Onda da análise FTIR do resíduo de produção de celulose funcionalizado por ácido nítrico

Gráfico 13 - Absorbância x Comprimento de Onda da análise FTIR do resíduo de produção de celulose funcionalizado por ácido fosfórico 
Gráfico 14 - Absorbância x Comprimento de Onda da análise FTIR do resíduo de produção de celulose funcionalizado por ácido acético

Gráfico 15 - Porcentagem de grãos que passam x Diâmetro dos grãos

Gráfico 16 - Umidade x Golpes no teste de limite de liquidez do solo puro 119

Gráfico 17 - Umidade x Golpes no teste de limite de liquidez do solo com $1 \%$ de resíduo de produção de celulose

Gráfico 18 - Umidade x Golpes no teste de limite de liquidez do solo com $5 \%$ de resíduo de produção de celulose

Gráfico 19 - Umidade x Golpes no teste de limite de liquidez do solo com $10 \%$ de resíduo de produção de celulose

Gráfico 20 - CTC Total a pH 7 em amostras de solo com teores de

RPC de $0 \%, 1 \%, 5 \%$ e $10 \%$

Gráfico 19 - Acidez potencial em amostras de solo com teores de RPC de $0 \%, 1 \%, 5 \%$ e $10 \%$

Gráfico 20 - Soma de Bases Trocáveis em amostras de solo com teores de RPC de $0 \%, 1 \%, 5 \%$ e $10 \%$ 128

Gráfico 21 - Valor A em amostras de solo com teores de RPC de 0\%, $1 \%, 5 \%$ e $10 \%$ 129

Gráfico 22 - Valor V em amostras de solo com teores de RPC de 0\%, $1 \%, 5 \%$ e $10 \%$ 130

Gráfico 23 - Sódio em amostras de solo com teores de RPC de 0\%, $1 \%, 5 \%$ e $10 \%$ 
Gráfico 24 - Alumínio em amostras de solo com teores de RPC de $0 \%, 1 \%, 5 \%$ e $10 \%$

Gráfico 25 - Hídron em amostras de solo com teores de RPC de 0\%,

$1 \%, 5 \%$ e $10 \%$

Gráfico 26 - Cálcio em amostras de solo com teores de RPC de 0\%,

$1 \%, 5 \%$ e $10 \%$

Gráfico 27 - Magnésio em amostras de solo com teores de RPC de $0 \%, 1 \%, 5 \%$ e $10 \%$ 134

Gráfico 28 - Potássio em amostras de solo com teores de RPC de $0 \%, 1 \%, 5 \%$ e $10 \%$ 134 


\section{1.}

\section{Introdução}

A fertilidade dos solos é de enorme importância para a sustentabilidade da produção primária e, em particular, da produção de alimentos, exercendo função indispensável para os seres vivos dos níveis subsequentes das cadeias tróficas. Dessa forma, é relevante acrescentar ao solo substâncias que o tornem mais fértil.

Ao escolher a substância para essa finalidade, é interessante considerar alguma que, nas atividades de processamento de materiais, seja encarada como rejeito. Isso porque, em tais atividades, apesar de serem obtidos alguns produtos com finalidade importante e conhecida; são gerados outros, que não são o objetivo e recebem, então, a alcunha de resíduo. Quando um resíduo é simplesmente lançado em algum lugar, ele tende a criar desequilíbrios ecológicos. Diferentemente, se é incorporado como matéria-prima em outro processo, obtêm-se dois vistosos benefícios, que são o de evitar os impactos ambientais de uma disposição direta e, ainda, reduzir a quantidade de insumos a serem usados para abastecer o processo.

No caso dos solos, então, um resíduo que se apresenta como bom candidato para uso, por ser abundante e natural, é a biomassa. Ela é uma matéria remanescente de diversos processos industriais, apresentando-se como um bom candidato ao condicionamento de solos. Sua composição química é, majoritariamente, celulose, hemicelulose e lignina.

Diante disso, no presente trabalho, optou-se por observar possíveis benefícios ambientais decorrentes do uso da lignina, por meio da aplicação de resíduos com alto teor desse componente. Tal material foi então aplicado sobre o solo, atuando como um condicionador do mesmo, e também oxidado, para análise de uma possível melhor adequação de suas características a essa função.

Dessa forma, faz-se importante apresentar, inicialmente, uma série de definições, sobre as quais versará o capítulo de revisão bibliográfica. Ao fim dessa apresentação, elucidar-se-á o objetivo desta pesquisa, explicando-se mais detalhadamente os materiais a serem testados e os benefícios esperados. 
Então, o texto terá início com a definição do termo solo, padronizando o conceito usado neste trabalho. Em seguida, serão apresentadas diversas funções do mesmo para os seres vivos, dado que o manejo desse recurso nesta pesquisa visa a potencializar alguns desses serviços ambientais. Subsequentemente, será detalhado o termo erosão, por ser um fenômeno de grande importância no tema e estar relacionado ao objetivo do presente trabalho. Depois, serão apresentados os componentes das biomassas, visto que o material a ser misturado ao solo é dessa natureza. Apresentar-se-á, ainda, o conceito adotado para o termo resíduo, pois a biomassa a ser usada é residual de determinados processos. A definição de funcionalização será mostrada logo depois, visto que esse processo será feito sobre os resíduos de biomassa; e o capítulo termina discorrendo sobre os impactos ambientais do excesso de carbono na atmosfera, uma vez que a aplicação de biomassa ao solo visa também a atenuar esse problema. 


\section{2.}

\section{Revisão bibliográfica}

\section{1}

\section{Definições de solo}

O termo solo, por referir-se a um sistema complexo e de quantidade abundante no planeta, recebe variadas definições, dependendo dos objetivos principais que cada profissional tem ao lidar com o material. Assim, os seguintes conceitos foram listados por Lepsch (2002).

Os geólogos o descrevem como parte de eventos geológicos do chamado "ciclo geológico". Um engenheiro de trânsito, por sua vez, usa-o para se referir apenas ao nível mais baixo de altura, sobre o qual ocorrem deslocamentos. Um engenheiro de minas, diferentemente, pode vê-lo como o material que cobre minérios e necessita ser retirado. Engenheiros civis podem o considerar um material de construção, usado para erguer aterros, barragens e outras edificações. Ecólogos podem defini-lo como uma parte do ambiente que é condicionada por organismos vivos e também os influencia. Historiadores e arqueólogos o têm como um "gravador do passado". Para engenheiros agrônomos, o solo é tratado mais como a matéria capaz de fazer crescerem plantas.

Para engenheiros ambientais, todas essas definições são consideradas, buscando-se uma compreensão integrada do sistema. É fundamental destacar, ainda, a definição dos pedólogos, que também inclui todas as supracitadas e procura o observar como um objeto em si, o que é importante para avaliar as suas funções. Isso porque a pedologia é justamente a ciência que estuda o solo, dentro do seu conceito total, básico e essencial.

Então, no presente trabalho, cabe definir o solo de uma forma que abranja a todos esses aspectos. Para tanto, adotou-se a definição do autor Pinto (2006). Logo, o termo solo pode ser descrito como um conjunto composto por partículas sólidas oriundas da decomposição de uma rocha e de matéria orgânica; pelos espaços intermediários entre elas; e pelos fluidos, tanto líquidos quanto gasosos, 
que ocupam esses espaços. Os fluidos mais comuns são a água e o ar, mas podem ser diversos outros. Os solos diferenciam-se pelo tamanho e pela composição química dos grãos, sendo esta dependente da natureza da rocha matriz.

\section{2}

\section{Funções do solo}

Findas as definições, é importante explicitar as diversas funções que o solo exerce para os seres vivos. Seu estudo também é dividido entre as áreas do conhecimento, com distintos objetivos principais, mas a sapiência de todos os papéis do solo é fundamental para compreender sua relevância e também as metas deste trabalho. Assim, vale apresentar as funções listadas por Brady et al.(2013).

Uma das funções mais claras é a de sustentação mecânica, tanto para o crescimento de plantas quanto para o estabelecimento de construções antrópicas. O solo atua como apoio tanto para raízes quanto para o caule e demais áreas expostas dos vegetais, funcionando como uma base física. Da mesma forma, é nele que se escoram as fundações, paredes, pilares e quaisquer partes de edificações humanas.

Ainda no escopo das obras, deve-se citar que o solo pode ser usado como material de construção. Nesse caso, ele passa a constituir aterros, barragens, estradas e açudes, por exemplo. Para tal finalidade, ele é frequentemente misturado a outras substâncias, como o cimento, adquirindo propriedades mais adequadas.

Além disso, o solo tem uma outra função de grande importância. Trata-se do armazenamento de água, que fica disponível nos poros, podendo ser fornecida às plantas até mesmo durante períodos sem chuva, desde que a profundidade do solo seja suficiente para reter um volume aquoso adequado. Para efeitos de cálculo, define-se a capacidade de retenção de água como a "capacidade de um determinado material reter água, expresso pelo percentual de água retida em relação à massa total do material" (Instrução Normativa 35, 2006). A absorção da água pelas raízes é fundamental para as plantas, pela 
participação da molécula $\mathrm{H}_{2} \mathrm{O}$ em reações metabólicas - como a fotossíntese -, pelo transporte interno de substâncias via fluxo de seiva e pelo resfriamento da superfície foliar por transpiração, dentre diversas outras utilidades.

Vale ressaltar que a água do solo é extraída não apenas por plantas, mas também por outros seres, incluindo os humanos. Basta observar a consecução de água em aquíferos, que corroboram a atuação do solo no abastecimento público de água.

Ainda discorrendo sobre a capacidade de armazenamento, é necessário citar os gases, que, apesar de serem absorvidos nas folhas diretamente do ar, são fornecidos às raízes apenas pelos poros do solo. Nesse grupo, destacam-se o oxigênio, usado na respiração; e o gás carbônico, precursor da fotossíntese.

Também de acordo com Lepsch (2002), o solo atua, ainda, como armazém de outros nutrientes além da água e dos gases, pois retém sais minerais e outras substâncias, disponíveis aderidos às partículas sólidas ou mesmo dissolvidos na água intersticial. Existem 15 nutrientes essenciais, subdivididos em 2 grupos: macronutrientes, que são os absorvidos em quantidades relativamente grandes; e micronutrientes, usados em quantidades muito pequenas, mas, ainda assim, essenciais. O primeiro, com 9 representantes, é composto por carbono, oxigênio, hidrogênio, nitrogênio, fósforo, potássio, cálcio, magnésio e enxofre. O segundo possui também 9, sendo boro, cloro, cobre, ferro, manganês, molibdênio, níquel, cobalto e zinco. Há, ainda, outros elementos considerados benéficos, como silício, sódio e selênio.

Em consonância com a supracitada função de armazém de nutrientes, é válido estabelecer o conceito de fertilidade do solo, pois ele resulta justamente desse papel. Fertilidade é a capacidade de um solo fornecer nutrientes, em quantidade, forma e ambiente adequados, às plantas que nele se estabelecem. Para isso, o ambiente deve apresentar condições adequadas de temperatura, umidade e aeração; as formas dos nutrientes devem ser as disponíveis para a absorção radicular e a quantidade de todos os distintos nutrientes, sem exceção, deve ser a adequada para o metabolismo do vegetal. Essas quantidades seguem a "Lei do mínimo", estabelecida por Justus von Liebig (1840), e que significa que o crescimento vegetal é limitado pelo nutriente presente em menor quantidade, ainda que os demais estejam disponíveis em enormes suprimentos, pois todos são fundamentais, de modo que a escassez de apenas um deles já resulta na limitação do desenvolvimento do organismo (Lepsch, 2002). 
A fim de quantificar a fertilidade do solo, estabeleceu-se o conceito de Capacidade de Troca Catiônica (CTC). Então, sua explicação será feita a seguir, baseada no autor Ronquim (2010).

Para a adequada compreensão, deve-se primeiro saber que a superfície de algumas das partículas sólidas dos solos possui carga elétrica, sendo capaz de atrair íons e moléculas polarizadas, por meio de ligações reversíveis. Frequentemente, a superfície tem cargas negativas, de modo a atrair cátions. Então, pode-se mensurar a Capacidade de Troca Catiônica, que é a quantidade total dos cátions $\mathrm{Ca}^{+2}, \mathrm{Mg}^{+2}, \mathrm{~K}^{+}, \mathrm{H}^{+}$e $\mathrm{Al}^{+3}$ que pode ser retida em condição permutável.

O valor da CTC é expresso em número de mol por unidade de volume. No Estado de SP, por exemplo, o padrão é mmolc/ $\mathrm{dm}^{3}$ (milimols de carga por decímetro cúbico de solo) (Raij et al., 1996). Em outras áreas do Brasil, diferentemente, usa-se cmolc/dm ${ }^{3}$ (centimols de carga por decímetro cúbico de solo) ou ou $\mathrm{cmolc} / \mathrm{cm}^{3}$ (centimols de carga por centímetro cúbico de solo) (Donagemma et al., 2011).

Tal conceito, porém, tem subdivisões, que auxiliam em sua correlação com a fertilidade. Uma delas denomina-se "Soma de Bases Trocáveis" (SB), sendo composta por:

Valor $\mathrm{S}=\mathrm{SB}=\mathrm{Ca}^{+2}+\mathrm{Mg}^{+2}+\mathrm{K}^{+}$

Ao incluir o íon alumínio, tem-se a CTC Efetiva:

CTC Efetiva $=\mathrm{SB}+\mathrm{Al}^{+3}$

Por fim, ao somar todos os cátions, medidos em $\mathrm{pH}$ neutro $(\mathrm{pH}=7)$, tem-se a CTC Total a $\mathrm{pH}$ 7:

Valor $\mathrm{T}=\mathrm{CTC}$ Total a $\mathrm{pH} 7=\mathrm{CTC}$ Efetiva $+\mathrm{H}^{+}$

Esse estudo compartimentado é importante porque apenas a SB é considerada um contribuinte relevante para a fertilidade, visto que os cátions que a constituem são importantes nutrientes para as plantas. Diferentemente, o $\mathrm{Al}^{+3}$ e $\circ \mathrm{H}^{+}$, se muito abundantes, tornam $\circ \mathrm{pH}$ do solo excessivamente ácido e, consequentemente, inadequado para o desenvolvimento vegetal. Então, para que se tenha um eficaz indicador da fertilidade geral do solo, estabeleceu-se o conceito de "Saturação por Bases" (V\%): 
Valor $\mathrm{V}=\mathrm{V} \%=\frac{\mathrm{SB}}{\mathrm{CTC} \text { Total a } \mathrm{pH} 7} \times 100$

De acordo com ele, pode-se classificar o solo em eutrófico (fértil), no qual V\% $>=50 \%$, ou distrófico (pouco fértil), quando $\mathrm{V} \%<50 \%$.

Instituiu-se, ainda, a "Saturação por Alumínio" (m\%):

$\% \mathrm{Al}=\mathrm{m} \%=\frac{\mathrm{Al}}{\mathrm{CTC} \text { Total a pH } 7} \times 100$, onde Al é a concentração de $\mathrm{Al}^{+3}$.

Se $\mathrm{Al}^{+3}$ trocável $>=3 \mathrm{mmolc} / \mathrm{dm}^{3}$ e $\mathrm{m} \%>=50 \%$, diz-se que o solo é álico (muito pobre).

Nos solos em que a CTC é baixa, não se deve fazer adubação em uma grande quantidade de uma só vez, pois o excesso seria perdido por lixiviação. Da mesma forma, quando a retenção de $\mathrm{H}^{+}$trocável for pequena, não é recomendado que a calagem seja intensa.

Na maioria das vezes, um valor $\mathrm{V} \%$ entre $50 \%$ e $80 \%$ e pH entre 6,0 e 6,5 resultam em boa produtividade (Ronquim, 2010).

Há ainda o indicador "Acidez Potencial", que reúne os 2 cátions que contribuem para a redução de $\mathrm{pH}$ :

Acidez Potencial $=\mathrm{Al}^{+3}+\mathrm{H}^{+}$

Com isso, pode-se também expressar a CTC Total a pH 7 de outra maneira:

Valor $\mathrm{T}=\mathrm{CTC}$ Total a $\mathrm{pH} 7=$ Acidez Potencial $+\mathrm{SB}$

No presente trabalho, instituiu-se também o Valor $\mathrm{A}$, análogo ao Valor $\mathrm{V}$, mas representativo da acidez:

Valor $\mathrm{A}=\frac{\text { Acidez Potencial }}{\text { CTC Total a pH } 7} \times 100$

Assim sendo, um dos problemas que um solo pode apresentar é a baixa fertilidade, causada justamente pela falta de nutrientes em quantidade, forma e ambiente adequados. Logo, em solos com essa limitação, é válido adicionar substâncias que aumentem sua capacidade de reter a água e os demais minerais.

Outra função do solo é a proteção das plantas contra substâncias tóxicas. Isso se dá por meio da ventilação com gases, da decomposição ou adsorção de toxinas orgânicas e da supressão de organismos produtores das substâncias 
tóxicas. Similarmente, o solo pode abrigar organismos produtores de substâncias que estimulam o vigor vegetal.

O solo também protege os vegetais contra variações de temperatura, visto que atua como um isolante térmico para as raízes e para os microrganismos que residem no subsolo. Assim, ele evita alterações metabólicas danosas.

Mais uma função do solo que merece citação é a de reciclador de matérias-primas. Tal papel se dá pela assimilação de resíduos orgânicos, com a conversão em formas minerais aproveitáveis pelas plantas e a liberação do carbono na forma de gás, de modo a disponibilizá-lo para a fotossíntese e, com isso, dar prosseguimento ao ciclo natural.

Por fim, pode-se comentar sobre o solo como habitat para diversos organismos. Isso inclui não apenas os vegetais superiores, mas também diversas bactérias, protozoários e pequenos animais, cuja sobrevivência depende do correto abrigo no solo e de nutrientes que nele estão disponíveis.

\section{3}

\section{Erosão}

Um dos principais problemas que atinge o solo se intitula erosão. Então, cabe detalhar o tema, baseando-se em Bertoni et al. (2010).

Para efeitos de definição, pode-se dizer que a erosão é o processo de desprendimento das partículas sólidas do solo causado pela água e pelo vento. A força de arraste que uma corrente de ar ou uma enxurrada de água exerce sobre os grãos é capaz de os deslocar por grandes distâncias, reduzindo a espessura do solo disponível em determinado local.

No caso de erosão pela água, formam-se, ainda, canais de escoamento preferencial da enxurrada. Eles dão origem a sulcos que, ao aumentarem de tamanho, tornam-se voçorocas, as quais podem chegar a mais de uma centena de metros em comprimento e dezenas em profundidade.

De acordo com a FAO (Food and Agriculture Organization of the United Nations), conforme descrito por FAO e ITPS (2015), as mais confiáveis estimativas apontam que a erosão pela água ocasiona perdas de solo entre $20 \mathrm{e}$ 
$30 \mathrm{Gt} / \mathrm{ano}$, em todo o mundo. A eólica, por sua vez, tem taxa entre 500 e 3320 Tg/ano (0,5 e 3,32 Gt/ano, respectivamente). Tais números indicam a grande magnitude do problema.

Em diversas áreas, a taxa de erosão é maior que a de formação de novos solos. Nesses casos, pode-se considerar que o solo está sendo minerado, devendo ser visto como um recurso natural não-renovável (FAO e ITPS, 2015).

Bertoni et al. (2010) elucida que tal perda de solo propriamente dito acarreta, ainda, a perda de fertilidade da terra, mesmo quando remanesce alguma quantidade. Isso ocorre porque a retirada das camadas superiores principalmente do horizonte $A$ - do solo implica, concomitantemente, na saída de nutrientes, tanto aderidos às partículas quanto dissolvidos na água intersticial. Conforme dito por Mafra (2010), experimentos de campo têm indicado que o solo erodido é mais rico em nutrientes do que o que sofreu erosão, o que corrobora a visão de que, mesmo quando o solo permanece em quantidades suficientes para o cultivo agrícola, a perda na fertilidade é notável.

Ainda de acordo com Bertoni et al. (2010), ao se observar o exemplo de uma cultura de milho, vê-se que a redução de $5 \mathrm{~cm}$ de solo resulta em queda de $15 \%$ da produção. Se a perda for de $10 \mathrm{~cm}$, a redução produtiva é de $22 \%$; se for de $15 \mathrm{~cm}, 30 \%$; para $20 \mathrm{~cm}, 41 \%$; de $25 \mathrm{~cm}, 57 \%$; e, se a perda chegar a 30 $\mathrm{cm}$ do material, a diminuição chega a $75 \%$ da produtividade.

A erosão também causa empobrecimento da qualidade dos produtos agrícolas. Quando os nutrientes do solo se tornam escassos por causa da erosão, os alimentos produzidos tendem a apresentar carência de alguns elementos nutritivos (Bertoni et al. 2010).

É preciso ressaltar, também, que a erosão pode constituir um problema não apenas para a área de onde o solo saiu, mas também para o local onde ele se deposita após o transporte. Uma das consequências nessa linha, descrita por Mezine et al. (2016), é o assoreamento de corpos d'água, que representa a deposição de materiais sólidos no fundo desses corpos, resultando na redução da profundidade e, por vezes, no alargamento do leito, de modo a inundar áreas antes emersas. Além disso, as partículas depositadas na água, ao ficar em suspensão, afetam sua turbidez, reduzindo a disponibilidade de luz para a fotossíntese de microalgas e vegetais aquáticos. $O$ arraste de solos, adubos e agrotóxicos ainda acarreta mudanças na microflora aquática, atingindo, através da cadeia alimentar, diversos outros níveis tróficos. Logo, a erosão resulta em 
prejuízos para a qualidade das águas, impactando áreas diversas daquela onde ocorreu a perda do solo.

Para que um solo fique menos sujeito à erosão, é interessante observar como seu comportamento varia em função da umidade, de acordo com o apresentado pelo autor Pinto (2006). Cabe dizer, aqui, que a umidade de um solo é o quociente entre a massa de água e a massa de sólidos, conforme a equação a seguir:

$$
\mathrm{W}=\frac{\mathrm{mw}}{\mathrm{ms}}
$$

Onde $\mathrm{w}=$ umidade, $\mathrm{mw}=$ massa de água e $\mathrm{ms}=$ massa de sólidos .

A influência da umidade sobre o comportamento mecânico é descrita pelos Limites de Atterberg, que são o Limite de Liquidez (LL) e o Limite de Plasticidade (LP). Esses valores são medidos na fração fina do solo, passante na peneira Mesh 40 (0,42 mm), devido à sua alta superfície específica. Tais conceitos foram criados a partir da observação de que, quando um solo dessa granulometria está muito úmido, comporta-se como um líquido; quando perde água, torna-se plástico; e, quando perde ainda mais umidade, passa a ser quebradiço. Assim, instituiu-se o termo Limite de Liquidez para o teor de umidade acima do qual o solo tem comportamento mecânico similar ao de um líquido. Analogamente, o Limite de Plasticidade é a umidade acima da qual ele se assemelha a um material plástico, tendo o aspecto de um sólido maleável. Abaixo desse valor de umidade, o solo desagrega-se facilmente ao ser manuseado, dizendo-se que o mesmo está quebradiço. A diferença entre os valores do LL e LP chama-se Índice de Plasticidade (IP). A figura 1 ilustra tais definições. 


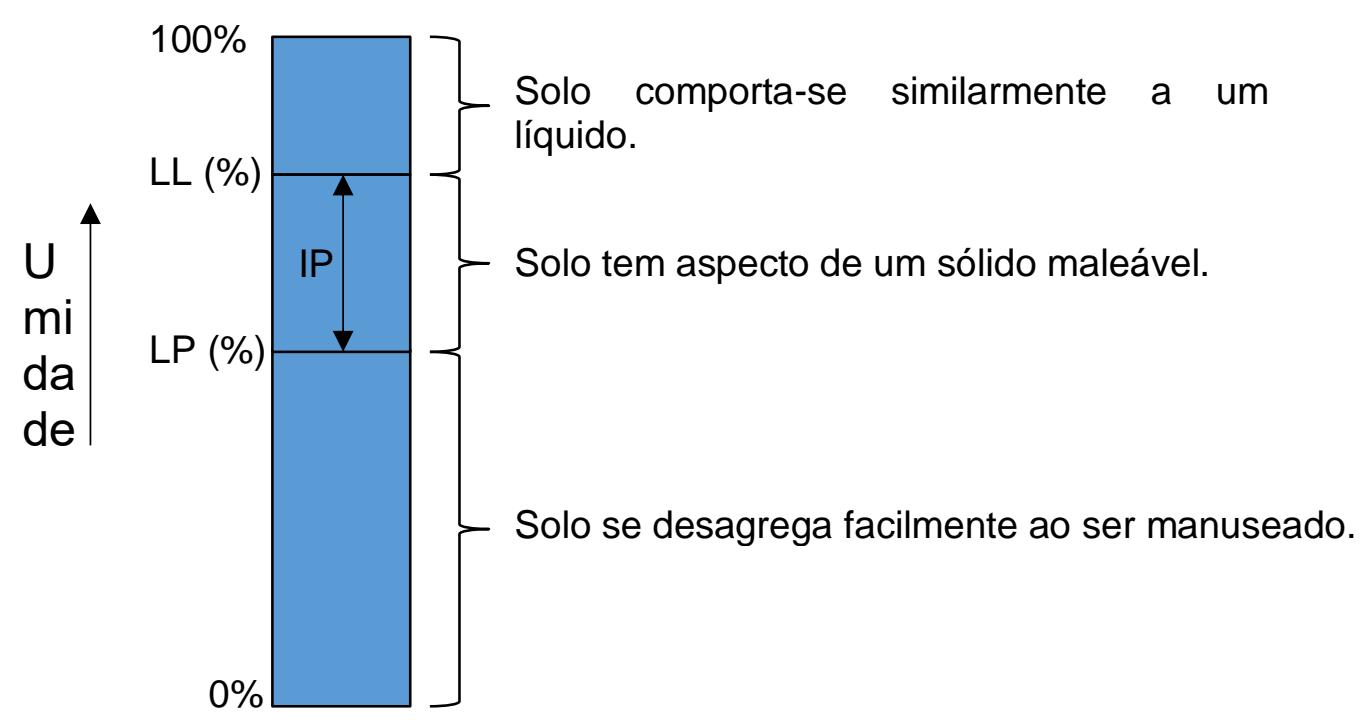

Figura 1 - llustração dos Limites de Atterberg

De acordo com Morgan et al. (1984), o solo com umidade acima do LL pode começar a fluir, sendo desprendido junto com a enxurrada e, dessa forma, sendo erodido. Em umidades abaixo desse limite, porém, a água pode atuar como um elemento agregador das partículas, dificultando a ação de agentes erosivos. Então, dentro do IP, o solo torna-se mais resistente à erosão. Abaixo do LP, porém, as partículas tendem a se desagregar mais facilmente, podendo ser arrastadas.

Nota-se, portanto, que um solo com elevado LL, baixo LP e, por consequência, amplo IP é mais resistente à erosão. Logo, o acréscimo ao solo de substâncias que tenham esse efeito se mostra uma medida promissora.

\section{4}

\section{Biomassa vegetal}

A biomassa vegetal é composta, em grande parte, por lignina, celulose e hemicelulose. Cada um desses constituintes será melhor descrito a seguir.

O termo lignina designa um polímero amorfo cujos monômeros são os fenilpropanóides que têm como precursores o p-coumarila, o coniferila e o sinapila (figura 2). A fração aromática de cada um dos três chama-se, 
respectivamente, p-hidroxifenila $(H)$, guaiacila $(G)$, e siringila $(S)$; sendo as ligninas classificadas de acordo com essa distinção (Buranov, 2008; Lewis et al., 1990).
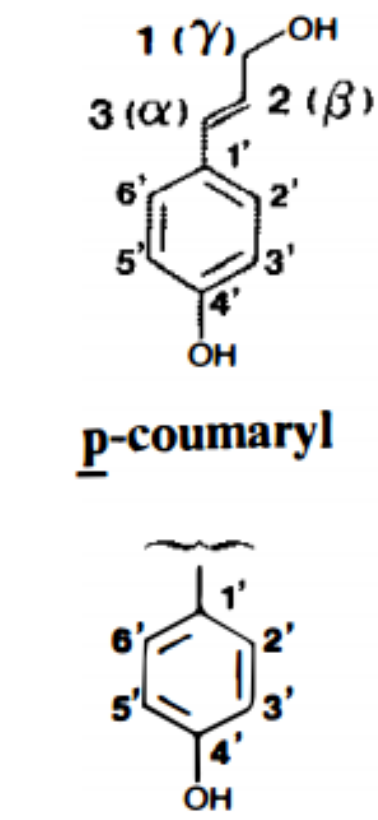

p-hydroxyphenyl (H)<smiles>COc1cc(/C=C/CO)ccc1O</smiles>

coniferyl<smiles>CCc1ccc(O)c(OC)c1</smiles>

guaiacyl (G)<smiles>COc1cc(/C=C/CO)cc(OC)c1O</smiles>
sinapyl<smiles>COc1cc(C)cc(OC)c1O</smiles>

syringyl (S)

Figura 2 - Precursores dos fenilpropanóides da lignina

A título de exemplo elucidativo, tem-se a estrutura da lignina de faia (figura 3). 


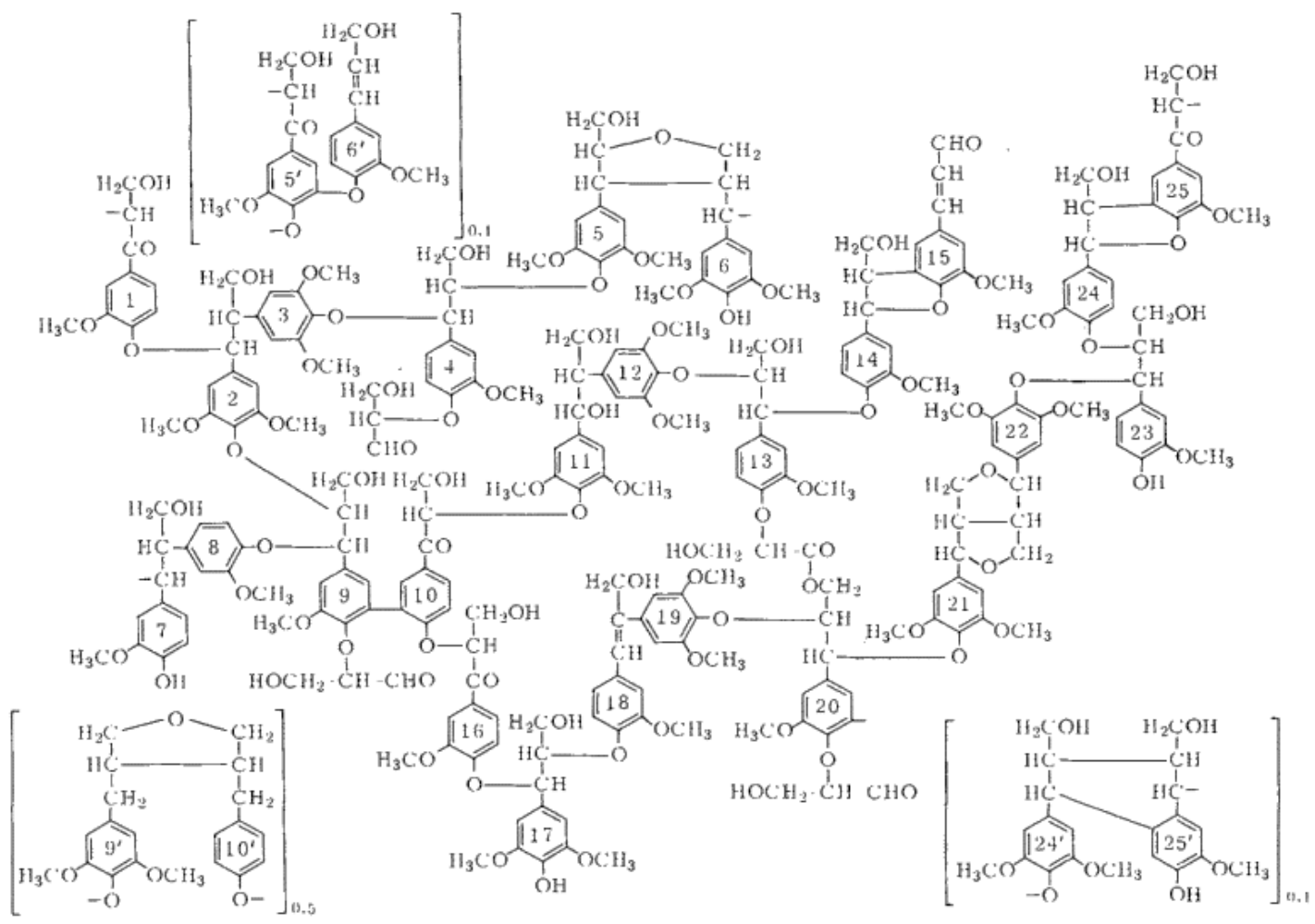

Figura 3 - Estrutura molecular da lignina de faia

Tal esquema mostra o encadeamento de 25 unidades de propanóide, das quais seis $(5 / 6,9 / 10,24 / 25)$ podem ser substituídas pelo dilignol, destacado entre colchetes (Nimz, 1974). Tal fórmula indica que as ligninas, apesar de terem monômeros bem definidos, apresentam estrutura polimérica bastante complexa.

A lignina é um componente de tecidos dos vegetais. Seu nome vem do termo em latim "lignum", que significa madeira. Porém, ela é encontrada também em plantas não lenhosas (Lewis et al., 1990). Em geral, as ligninas de madeiras duras ou angiospermas são do tipo $G$ e $S$, as de madeiras moles ou gimnospermas são do tipo $\mathrm{G}$ e as de gramíneas abrangem $\mathrm{G}, \mathrm{S}$ e H. Todavia, certas espécies de gimnospermas e gramíneas apresentam grande quantia de $G$ e S (Chen, 1991).

As principais funções dessa substância para as plantas são a de prover rigidez mecânica, transporte interno de água e nutrientes e proteção contra o ataque de microrganismos (Buranov et al., 2008).

Em termos estatísticos, as ligninas são o terceiro mais abundante polímero natural do planeta, ficando atrás apenas da celulose e da hemicelulose (Buranov 
et al., 2008). Sua quantidade, de acordo com Argyropoulos et al. (1998), é estimada em 300 bilhões de toneladas métricas no mundo, com produção pela natureza de 20 bilhões de toneladas métricas por ano.

Nos organismos vegetais, as ligninas apresentam-se associadas a moléculas de celulose e hemicelulose (Fengel et al., 1984; Badhan et al., 2007). Devido a isso, é importante conceituar essas duas outras substâncias, a fim de melhor embasar o presente trabalho.

A celulose é um polímero linear, com estrutura parcialmente cristalina e parcialmente amorfa (Laureano-Perez, 2005), composto por monômeros de dglicose associados por ligações $\beta-1,4$ glicosídicas (Fengel et al., 1984). Trata-se do polímero natural renovável mais abundante da Terra (Silva et al., 2009).

A hemicelulose, diferentemente, é um carboidrato complexo formado por diversos polímeros, como pentoses (como xilose e arabinose), hexoses (como manose, glicose e galactose) e ácidos de açúcar (Hendriks et al., 2009). Seu peso molecular é menor que o da celulose (Fengel et al., 1984). Ela exerce a função de conectar a celulose à lignina e conferir maior rigidez a toda a rede (Laureano-Perez, 2005). Dentre essas três substâncias, a hemicelulose é a mais sensível a sofrer mudanças químicas induzidas por variações térmicas (Hendriks et al., 2009).

Além dos três componentes supracitados, a biomassa lignocelulósica contém materiais denominados extrativos. Dentre eles, podem-se destacar os açúcares simples, ácidos graxos, amido, ceras, cinzas, compostos fenólicos, gomas, óleos essenciais, pectinas, proteínas, saponinas e terpenos. Elas são importantes para o metabolismo vegetal e proteção contra pragas, mas inibem processos de conversão da biomassa, sendo então, muitas vezes, retiradas antes dos processos químicos de separação (Fengel et al., 1984).

A associação entre lignina, celulose e hemicelulose pode ser simbolizada pela figura 4. 


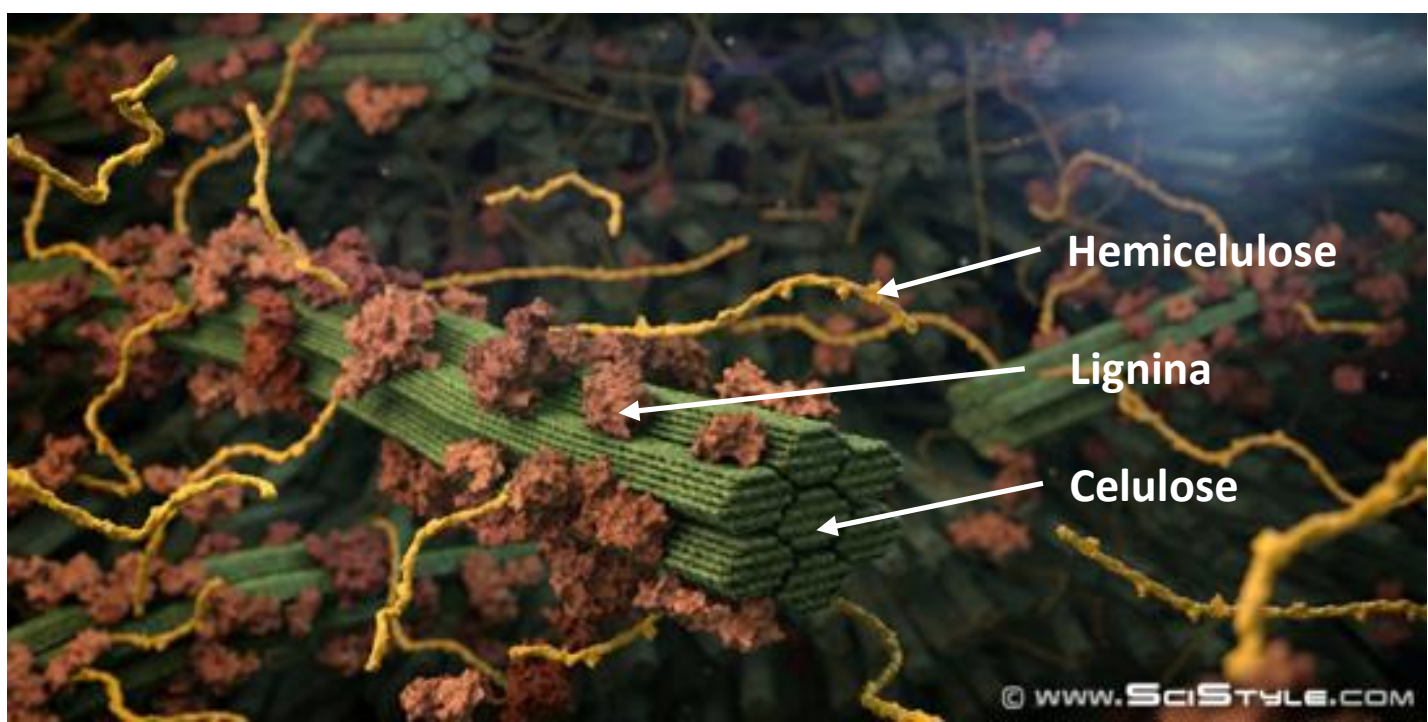

Figura 4 - llustração de material lignocelulósico (http://portfolio.scistyle.com/Lignocellulose, acessado em 14/06/2016).

\section{5}

\section{Resíduo}

Para a adequada compreensão dos objetivos deste trabalho, faz-se importante, também, definir o conceito adotado para o termo resíduo. De acordo com Ferreira (2001), resíduo é o que resta de qualquer substância, resto. Portanto, na cadeia de processamento de materiais, optou-se, neste trabalho, por dar esse nome aos produtos que não são o objetivo principal da atividade, mas que são gerados ao longo do processo.

Assim, eles tendem a ser descartados ou, preferencialmente, reaproveitados como insumo de outras atividades. Entretanto, quando um resíduo é simplesmente lançado em algum lugar, ele tende a criar desequilíbrios ecológicos. Diferentemente, se é incorporado como matéria-prima em outro processo, obtêm-se dois vistosos benefícios, que são o de evitar os impactos ambientais de uma disposição direta e, ainda, reduzir a quantidade de insumos a serem usados para abastecer o processo. Logo, é de enorme relevância promover pesquisas de novos usos para materiais residuais, estabelecendo-se, com isso, utilidades pioneiras, agregação de valor econômico ou funções mais únicas ou de maior importância que as já conhecidas. 


\section{6}

\section{Funcionalização}

Sobre a química de superfícies, é válido apresentar algumas informações, baseadas em McCreery et al. (2012).

As propriedades químicas da superfície de um material são fundamentais para definir a interação do mesmo com o ambiente à sua volta. Isso ocorre porque a área superficial é a primeira camada a ser "vista" pelas moléculas do espaço exterior, de modo que diversos processos podem ocorrer nesse contato. Os grupos funcionais presentes nessa superfície podem ter caráter hidrofílico, hidrofóbico, ácido, quelante, entre outros; definindo as relações que ocorrerão na interface com outras substâncias.

A fim de alterar essas propriedades, existem os processos de modificação química de superfícies. Dentre eles, destaca-se a funcionalização, que nada mais é que a alteração de grupos funcionais presentes na mesma, de modo a Ihe conferir características distintas das originais e mais adequadas a uma finalidade pretendida. Para tanto, é comum a incorporação de átomos de uma substância exterior, o que se processa quando as forças de adesão, que são as vistas entre um átomo ou molécula da superfície a ser modificada e um átomo ou molécula do material modificador; são mais fortes que as de coesão, que são entre dois átomos ou moléculas do mesmo material modificador. Nessas circunstâncias, os átomos ou moléculas modificadoras passam a fazer parte da superfície, alterando seus grupos funcionais e, consequentemente, suas propriedades químicas.

De acordo com Leite (2013) e Dick et al. (2016), no caso de materiais compostos majoritariamente por carbono, um processo possível é a oxidação por solução ácida. Nela, o contato com o ácido resulta na incorporação de oxigênio à matriz, originando grupos funcionais do tipo carboxila $(-\mathrm{COOH})$ e hidroxila $(-\mathrm{OH})$, tanto nos radicais alquila quanto no carbono de anéis aromáticos.

Como foi descrito neste trabalho, a lignina é composta, significativamente, por carbono. Assim, espera-se que a funcionalização da mesma com ácido tenha os efeitos supracitados. 
Conforme dito por Doumer et al. (2016), as carboxilas e hidroxilas obtidas pelo processo contêm, em seu átomo de oxigênio, um par de elétrons livres. Dessa forma, podem formar um complexo coordenado com espécies químicas de carga positiva. Consequentemente, é possível sua atuação como agente quelante de cátions metálicos, o que permite a adsorção de nutrientes desse tipo, como os íons $\mathrm{K}^{+}, \mathrm{Ca}^{+2}$ e $\mathrm{Mg}^{+2}$. Logo, a inserção no solo de biomassa funcionalizada pode incrementar a CTC.

Além disso, o oxigênio também pode adsorver água, com ligações de hidrogênio. Logo, ao ser adicionada ao solo, a biomassa funcionalizada pode ter o benéfico papel de elevar a retenção de água.

Ainda sobre o incremento sortivo, é importante citar que ele se deve também a uma outra consequência do tratamento com ácido, citada por Bhatnagar et al. (2010), que é o alargamento dos poros. Tal mudança física aumenta a superfície de contato do material com os cátions e com a água, possibilitando uma maior adesão.

Diante dessas características, a biomassa funcionalizada tem potencial para ser considerada um condicionador do solo. Isso porque, de acordo com a Instrução Normativa 35/2006 (Ministério Da Agricultura, Pecuária E Abastecimento; 2006), esse título é dado a um "produto que promove a melhoria das propriedades físicas, físico-químicas ou atividade biológica do solo, podendo recuperar solos degradados ou desequilibrados nutricionalmente". Ainda segundo o documento, o produto "deve apresentar as seguintes garantias de especificações mínimas para o solo": capacidade de retenção de água de 60\% e capacidade de troca catiônica de 200 mmolc / kg.

\section{7}

\section{Excesso de gases com carbono na atmosfera}

Aquecimento Global, ou Efeito Estufa Acentuado, é o termo cunhado para designar a elevação da temperatura atmosférica média da Terra. Segundo apontam pesquisas, essa tendência de aumento é natural, apesar de ainda não ser claro o seu motivo. Porém, nas últimas décadas, tem sido verificado um aumento insustentavelmente rápido nas médias térmicas do planeta, o que se 
deve não a um processo natural, e sim a um Aquecimento Global Antrópico, que, como o próprio nome sugere, é causado por atividades humanas (IPCC, 2014).

Para a adequada compreensão das causas desse problema, é relevante citar que a atmosfera da Terra é composta, em parte, por gases que contêm carbono, a exemplo do $\mathrm{CO}_{2}$ (gás carbônico) e $\mathrm{CH}_{4}$ (metano). Essa presença é de enorme importância para os seres vivos, por possibilitar processos de obtenção de energia, como a fotossíntese, que demanda $\mathrm{CO}_{2}$, e a respiração metanotrófica, que oxida o $\mathrm{CH}_{4}$. Além disso, eles exercem a função de "gasesestufa", que são capazes de regular a temperatura do planeta. Tal regulação ocorre devido ao Efeito Estufa, explicado a seguir.

Após parte da luz proveniente do sol atravessar a atmosfera, atingir a superfície da Terra e a aquecer, ocorre um resfriamento por meio da liberação dessa energia como espectro infra-vermelho, o qual flui, então, no sentido de sair da Terra. Porém, alguns gases da atmosfera - os gases-estufa - possuem a capacidade de refletir o calor ascendente, fazendo, assim, com que uma parte significativa deste fique retida na atmosfera. Com isso, a temperatura do planeta permanece, em condições naturais, em uma média de $15^{\circ} \mathrm{C}$, o que facilita a sobrevivência de diversos organismos, fazendo do Efeito Estufa um fenômeno indispensável à manutenção das atuais formas de vida do planeta.

No entanto, é importante ressaltar que, em função de diversas atividades humanas, como o acelerado desmatamento e a queima de combustíveis fósseis; a quantidade de gases com carbono tem aumentado na atmosfera, e, apesar de ser necessário que eles estejam no ar, a sua presença em excesso acarreta graves malefícios.

Um dos problemas gerados pela concentração excessiva de carbono na atmosfera é o Aquecimento Global Antrópico. De acordo com o IPCC (2011), este nada mais é do que o aumento da retenção, na atmosfera, do calor irradiado pela Terra, o que se deve à maior quantidade de gases-estufa no ar. Com isso, a temperatura média de todo o planeta acaba por se elevar, e o aumento é ainda mais intenso nas áreas em que os gases são mais emitidos, como as zonas industriais. Tal elevação térmica resulta em uma série de problemas ambientais.

Além do referido aquecimento, o excesso de gás carbônico na atmosfera acarreta, ainda, o problema da Acidificação de Corpos Líquidos. Isso porque o 
$\mathrm{CO}_{2}$ se dissolve em oceanos, rios e demais ambientes aquáticos e é capaz de reagir com as moléculas de água, por meio do seguinte mecanismo:

$$
\mathrm{H}_{2} \mathrm{O}_{(\mathrm{l})}+\mathrm{CO}_{2(\mathrm{~g})}->\mathrm{H}^{+}{ }_{(\mathrm{aq})}+\mathrm{HCO}_{3}^{-}{ }_{(\mathrm{aq})}
$$

Logo, tem-se a produção de $\mathrm{H}^{+}$e a consequente acidificação do meio. Tal mudança de $\mathrm{pH}$ induzida por atividades antrópicas também cria diversos danos ambientais.

A fim de combater os problemas do excesso de carbono na atmosfera, é importante o processo de Sequestro de Carbono, descrito por Carvalho et al. (2010). Ele consiste na fixação, em compostos sólidos, do carbono proveniente de compostos gasosos, a fim de reduzir a presença de gases com carbono na atmosfera e, por conseguinte, combater os problemas de aquecimento e acidificação supracitados.

Uma das formas mais simples e naturais de sequestrar o carbono é por meio do crescimento vegetal, visto que, no processo de fotossíntese, as plantas captam o carbono do $\mathrm{CO}_{2}$ e o fixam sob a forma de matéria orgânica. Porém, para que essa fixação seja mais efetiva, é útil que essa matéria não seja inteiramente decomposta, nem por processos naturais e nem por queima antrópica, pois isso faria o carbono retornar à atmosfera. Então, é válido que a biomassa, mesmo após o término do ciclo de vida da planta, fique retida no ecossistema. Essa retenção pode ser feita, por exemplo, tratando-se a matéria para evitar sua decomposição e a acrescentando ao solo.

\section{8}

\section{Histórico}

Findas as definições, é válido apresentar um breve histórico, a fim de chamar a atenção para a antiguidade da ciência dos solos e ressaltar ainda mais a importância da mesma. Para tanto, cabe apontar alguns eventos, descritos por Lepsch em 2002.

Os estudos sobre solos são documentados pela humanidade há milênios. Por exemplo, na China, há 6600 anos, as terras do país foram divididas em 9 classes, de acordo com a produtividade, para que os tamanhos das propriedades e o valor dos impostos fossem baseados nesses critérios. Isso 
aponta o quão é antigo o discernimento sobre a qualidade dos solos, especialmente no que tange ao seu papel como meio para o crescimento de vegetais.

Há cerca de 2500 anos, os trabalhos de Hipócrates traçam uma analogia em que o solo está para a planta assim como o estômago está para os animais. Tal conceito se explica porque, assim como o estômago processa alimentos para uma posterior absorção, fundamental ao crescimento e manutenção do corpo; também o solo fornece nutrientes necessários para que as plantas cresçam e frutifiquem.

Há 2000 anos, Columela relacionou a cor dos solos à fertilidade, apontando que os mais escuros seriam os melhores. Tal conceito vai ao encontro dos de hoje, em que a matéria orgânica, responsável pela coloração escura, é um dos fatores que torna um solo mais fértil.

Em 1563, Bernard Palissy redigiu um tratado sobre solos, descrevendo-os como fonte de nutrientes minerais para as plantas. Tal conceito, apesar de correto, permaneceu desconhecido por muito tempo. Por exemplo, em 1629, o alquimista holandês van Helmont afirmou que os vegetais se nutriam apenas do gás carbônico do ar e da água do solo. Esse conceito, apesar trazer informações corretas, ainda não é completo, pois há diversos outros nutrientes indispensáveis à vida das plantas.

No início do século XIX, Tahaer e Von Wullfen criaram a "Teoria do húmus", de acordo com a qual os vegetais assimilariam os restos orgânicos diretamente do solo. Ela foi importante no estabelecimento desse termo no meio científico, ainda que necessitasse ser complementada.

O químico Justus von Liebig, em 1840, demonstrou que as plantas não se alimentavam diretamente das substâncias orgânicas, e sim de elementos e compostos minerais, água e gás carbônico, sendo o húmus um estágio intermediário entre a matéria orgânica e os nutrientes minerais. Tal teoria foi cientificamente revolucionária, estabelecendo a base para técnicas de fertilização do solo.

O naturalista russo V. V. Dokouchaiev, em 1877, estudou os efeitos de uma seca sobre os solos da Ucrânia. Anos depois, também observou o solo de Gorki, de clima mais frio e úmido. Nesses trabalhos, ele correlacionou o solo aos diferentes tipos de clima, incluindo na ciência dos solos uma importante variável. 
Além disso, detectou uma sucessão de camadas horizontais compondo o solo, de modo a reconhecer a diferença composicional ao longo da profundidade. Tais diferenças foram atribuídas às diversas variáveis que moldam o solo, como o próprio clima. Com isso, Dokouchaiev estabeleceu muitas das bases da ciência dos solos, proporcionando contribuições que permanecem até a atualidade.

Além desses fatos descritos por Lepsch, é importante citar outro, mais recente. Como um desdobramento da temática da matéria orgânica no solo como fonte de nutrientes minerais, tem-se o trabalho de Glaser et al. (2012), em que foi descrito um solo da Floresta Amazônica. Trata-se da "Terra Preta de Índio", material rico em matéria orgânica, nutrientes e fragmentos de cerâmica indígena produzidos há séculos, sendo esta característica indicativa de que tal solo é antropogênico. Essa riqueza de nutrientes deriva da elevada Capacidade de Troca Catiônica da matéria orgânica desse solo. Tal estudo foi importante para ratificar a correlação entre a matéria orgânica e a fertilidade, dando margem a testes futuros de mistura de substâncias orgânicas ao solo com a finalidade de aumentar sua oferta de nutrientes. Testes desse tipo foram feitos no presente trabalho, conforme ficará claro mais adiante.

Ainda sobre o incremento da fertilidade por meio da aplicação de matéria orgânica, tem-se o trabalho de Miranda et al. (2017). Nele, o carvão vegetal foi usado para elevar a capacidade de troca catiônica em culturas de arroz e feijãocaupi, reforçando a aplicabilidade da matéria orgânica para esse fim. Foram notados aumentos na retenção de potássio trocável e de nitrogênio.

Outro trabalho que comprova o papel da matéria orgânica na elevação da fertilidade é o de Madari et al. (2010). Vê-se aqui o uso de biomassa carbonizada como fonte de carbono pirogênico, incorporada ao solo com enxada rotativa. Tal condicionamento elevou tanto a disponibilidade de cátions no solo quanto a produtividade de plantações de arroz, corroborando o caráter benéfico do material introduzido.

Cabe citar, ainda, o uso de matéria orgânica como amenizante em solos contaminados, por meio da imobilização dos contaminantes a partir da adsorção. Isso foi estudado por Santos et al. (2015), aplicando-se carvão vegetal e ácidos húmicos a um solo, no qual havia chumbo. Apesar de não visar à fertilidade, como é o caso do presente trabalho, essa ação ratifica a vocação da matéria orgânica como adsorvente condicionante de solos. 
A fim de melhor explicitar os usos que atualmente são feitos com os materiais estudados neste trabalho, é fundamental destacar o destino comum do licor negro da indústria de celulose. Conforme apresentado por Santos (2008), tal efluente é frequentemente queimado para geração de energia nas próprias plantas industriais, havendo também trabalhos de oxidação pelo processo de gasificação, a fim de otimizar a energia fornecida. Contudo, por ser uma queima, tal procedimento emite gases com carbono para a atmosfera, de modo a ser potencialmente poluidor. Ainda que o carbono emitido tenha sido antes absorvido pela biomassa vegetal, seu retorno à atmosfera desperdiça a oportunidade de um sequestro de carbono mais duradouro. Assim, a assimilação da matéria orgânica do licor negro, no estado sólido, ao solo combate o excesso de carbono no ar, de modo a criar um benefício ambiental.

Diante dessa observação de trabalhos já publicados, nota-se que é comum o condicionamento de solos por matéria orgânica na forma de carvão. Entretanto, não foram encontrados na literatura aplicações de resíduos ricos em lignina que não tenham sido carbonizados, sendo mais comum o seu uso como fonte de energia a partir de combustão. Assim, o presente trabalho propôs-se a testar compostos ricos em lignina, provenientes do licor negro, como condicionadores do solo; bem como estudar mecanismos de funcionalização dessa matéria orgânica. Também foi analisada a obtenção de matéria rica em lignina a partir de resíduos de biomassa, para uso análogo ao do resíduo sólido de licor negro. 


\section{3.}

\section{Objetivos}

\section{1}

\section{Geral}

O presente trabalho tem o objetivo de produzir benefícios ao meio ambiente a partir da aplicação do resíduo de produção de celulose (RPC), proveniente do licor negro e rico em lignina, sobre um solo. Tais ganhos são diversificados, conforme será detalhado adiante, tendo como ponto em comum o fato de representar uma retenção de matéria em forma e local mais adequados à qualidade ambiental. Para tanto, buscou-se caracterizar o RPC e avaliar a sua aplicação no solo em relação às características físicas e químicas do resíduo.

\section{2}

\section{Específicos}

As referidas retenções são de água, de solo, de cátions nutrientes, de carbono e de um resíduo, de acordo com os seguintes detalhes. Assim, buscaram-se as metas a seguir.

Aumentar da retenção de água do solo. Estima-se que o composto rico em lignina, especialmente quando funcionalizado, atue como um eficaz adsorvente para as moléculas do líquido, elevando o volume de água armazenado no solo e, assim, permitindo-o melhor hidratar os vegetais nele residentes.

Elevar a resistência do solo à erosão, como consequência da supracitada retenção de água, de modo a possibilitar a retenção do próprio solo no seu local de origem. Isso será buscado por meio da elevação do Limite de Liquidez e redução do Limite de Plasticidade, com a consequente ampliação do Índice de Plasticidade, que torna os grãos mais coesos dentro de uma faixa maior de umidade. 
Verificar o aumento da retenção no solo de cátions que sirvam como nutrientes para as plantas. Isso tende a ocorrer por causa de um aumento na Capacidade de Troca Catiônica, resultante da adsorção dos íons na superfície da lignina, com consequente incremento da fertilidade.

Armazenar o carbono na forma sólida, visto que a lignina contém esse elemento em sua composição. Assim, ao manter o carbono sólido dentro da lignina em vez de o transformar em gás por meio de uma queima para geração de energia, promove-se uma operação de Sequestro de Carbono. Consequentemente, combate-se o excesso de gases com carbono na atmosfera, evitando-se o Aquecimento Global e a Acidificação dos Oceanos.

Reter um resíduo em um contexto mais adequado. Isso porque o material usado é um resíduo da produção industrial de celulose, e seu emprego no solo evita que ele seja descartado de maneira poluente, dando-Ihe uma função mais nobre. Simultaneamente, essa aplicação poupa o uso de outras matérias-primas que poderiam ser requeridas para condicionar o solo, proporcionando uma economia de materiais que configura mais um notável benefício ambiental. 


\section{4.}

\section{Materiais e Métodos}

Para alcançar os objetivos deste trabalho, usaram-se dois materiais primários: o bagaço de cana-de-açúcar $(B C A)$ e o resíduo de produção de celulose (RPC).

O BCA foi proveniente da produção de caldo de cana, comercializado em uma feira na Praça Santos Dumont, bairro da Gávea, Rio de Janeiro-RJ. Sua aplicação foi como matéria a ser modificada pelo processo Klason, o que foi detalhado na seção "Materiais e Métodos - Obtenção do composto rico em lignina". Contudo, devido ao baixo rendimento do processo, as etapas subsequentes da pesquisa, correspondentes à funcionalização e à aplicação em um solo, foram feitas com o RPC.

O RPC foi proveniente do resíduo licor negro da fabricação de celulose, doado para esta pesquisa por uma empresa do ramo. Ele tem o aspecto de um pó e é rico em lignina, de modo a atender às expectativas de material necessário a este trabalho.

\section{1}

\section{Obtenção do composto rico em lignina a partir do bagaço de cana}

A obtenção de lignina a partir de bagaço de cana-de-açúcar foi feita de acordo com o método Klason. A intenção inicial do processo seria avaliar não só sua viabilidade, mas também sua produtividade, para que, possivelmente, toda a lignina usada nos testes subsequentes fosse originária desse mecanismo.

Seguindo o método, primeiramente, buscou-se retirar os extrativos da biomassa. Para tanto, $200 \mathrm{~mL}$ de solução de $95 \%$ de etanol foram acondicionados em um frasco Erlenmeyer, que foi então colocado sobre uma manta térmica. Paralelamente, $10 \mathrm{~g}$ de bagaço foram divididos em 3 porções iguais, sendo cada uma envolvida em papel filtro, conforme a figura 5. Então, colocaram-se os 3 conjuntos no interior de um Extrator Sohxlet, que foi depois 
acoplado sobre o Erlemeyer que continha o etanol. Por fim, o tubo de circulação de água foi posto na parte superior do extrator, montando-se o típico sistema de extração Sohxlet.

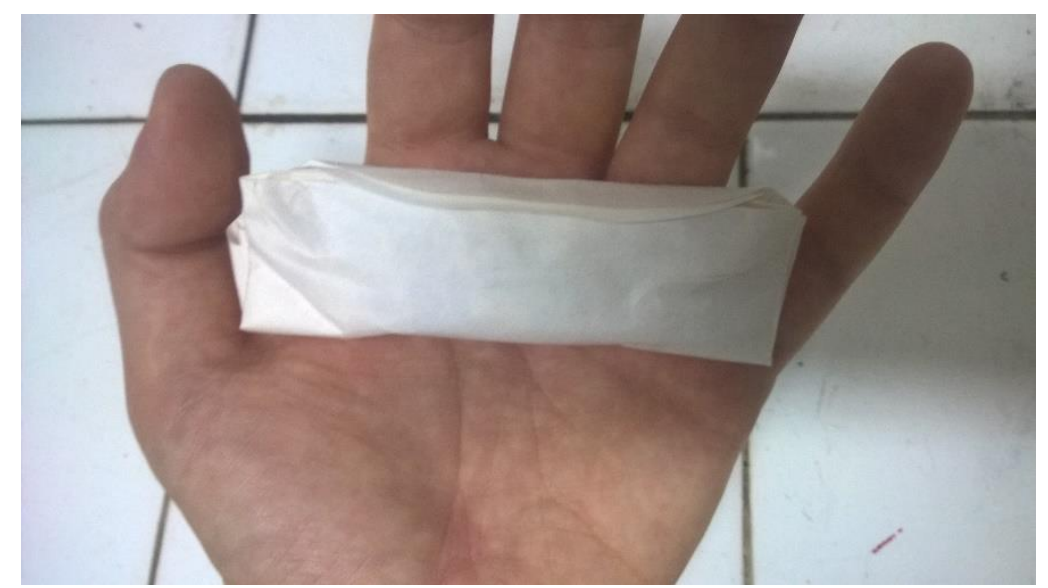

Figura 5 - Bagaço de cana envolvido por papel filtro

Dando prosseguimento ao ensaio, iniciou-se a circulação da água da torneira, para resfriamento contínuo da parte mais alta do sistema. Logo depois, a manta foi ativada, de modo a aquecer o etanol até sua ebulição. Isso resultou na subida de vapor do álcool até o extrator, no topo do qual houve a condensação e o consequente gotejamento sobre o bagaço. Esse mecanismo de refluxo foi mantido por 1h, contada a partir do início da ebulição.

Ao fim dessa etapa, o bagaço, já livre dos extrativos, foi direcionado para separação da lignina. Para tanto, ele foi acondicionado em um béquer de $1 \mathrm{~L}$. Então, misturou-se à biomassa $200 \mathrm{~mL}$ de uma solução de ácido sulfúrico $65 \%$, e se aguardou 1h, durante a qual ocorreu a reação de separação. As figuras 6 e 7 elucidam essa etapa. 


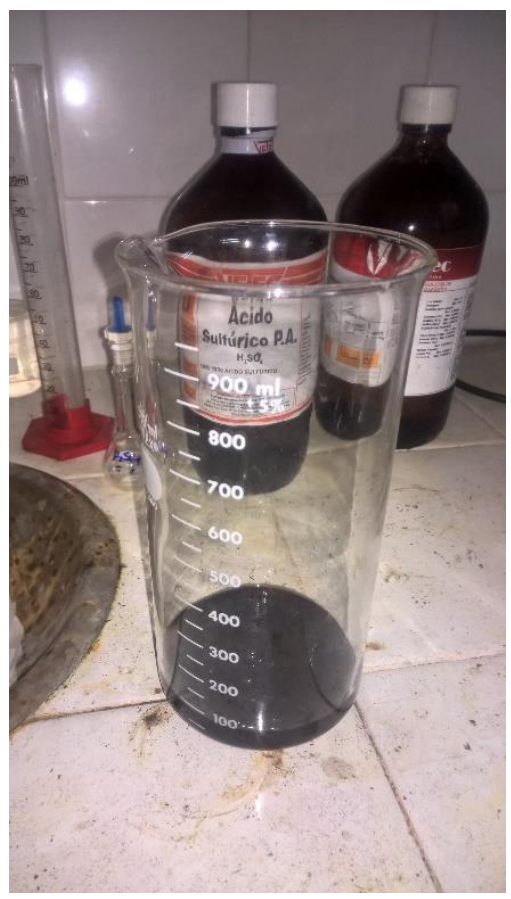

Figura 6 - Bagaço livre de extrativos reagindo com ácido sulfúrico, em vista lateral

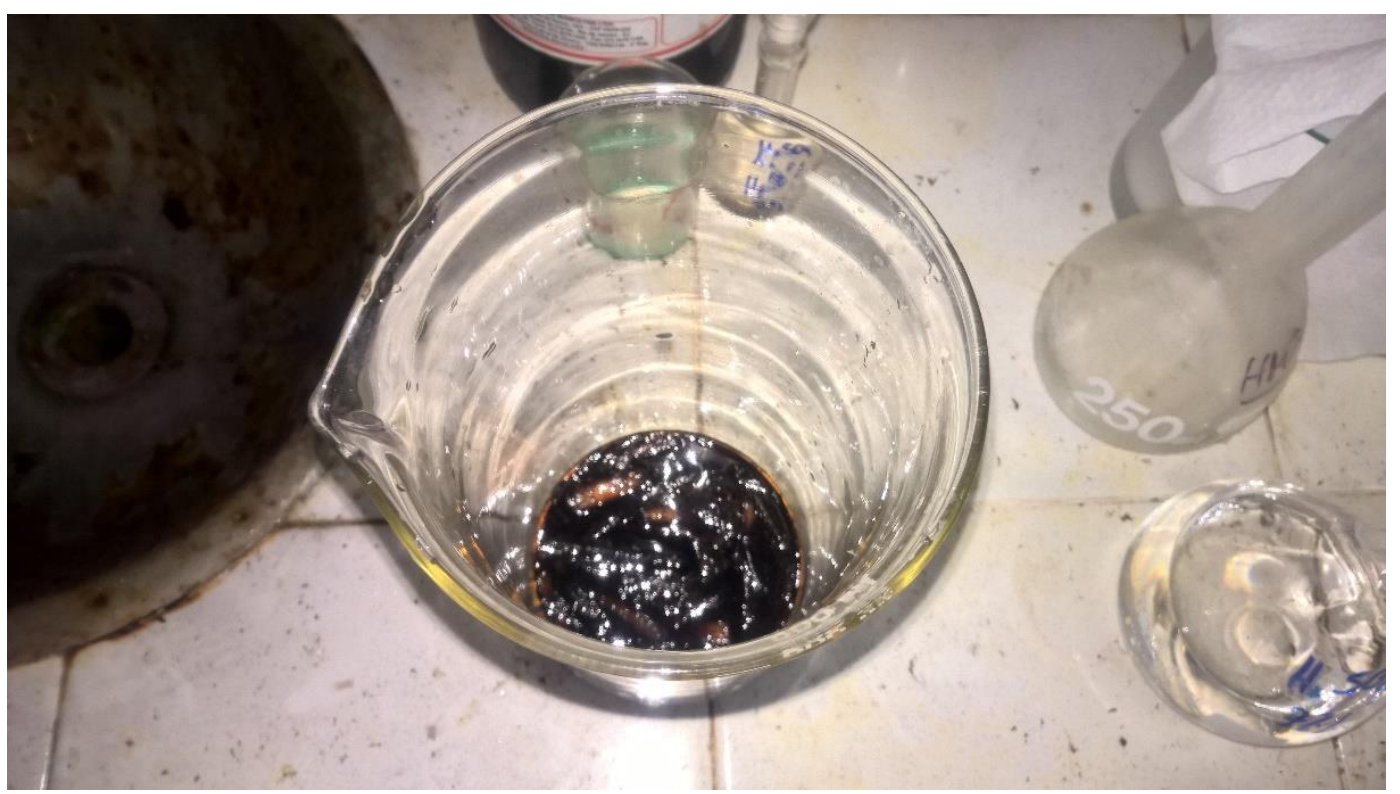

Figura 7 - Bagaço livre de extrativos reagindo com ácido sulfúrico, em vista superior

Findo esse tempo, acrescentou-se água destilada, para diluição, até o volume total do béquer. Em seguida, o conjunto foi filtrado, a vácuo. A montagem 
do sistema de filtração foi feita com uma bomba de sucção, um frasco de armadilha, um frasco Erlenmeyer para recolhimento do líquido filtrado, um funil de Buchner e papel de filtro comercial de café (selecionado por seu grande tamanho de poro, suficiente para reter a amostra sem tornar o processo demasiadamente demorado).

Após a separação completa entre o líquido e a lignina sólida resultante, executou-se a lavagem da mesma. Para tanto, bastou adicionar água destilada, no próprio funil onde ela estava retida, até total encobrimento; e acionar novamente a bomba para uma nova separação entre sólido e líquido. Tal sequência de operações foi feita diversas vezes, sempre com medição do pH em um pHmetro, até que o líquido resultante ficasse com pH estável.

Terminada a lavagem, o material sólido foi raspado, com auxílio de uma espátula, e colocado sobre um cadinho cerâmico. Então, fez-se uma secagem de $24 \mathrm{~h}$ em estufa, a $120^{\circ} \mathrm{C}$. O resultado foi o exibido na figura 8 .

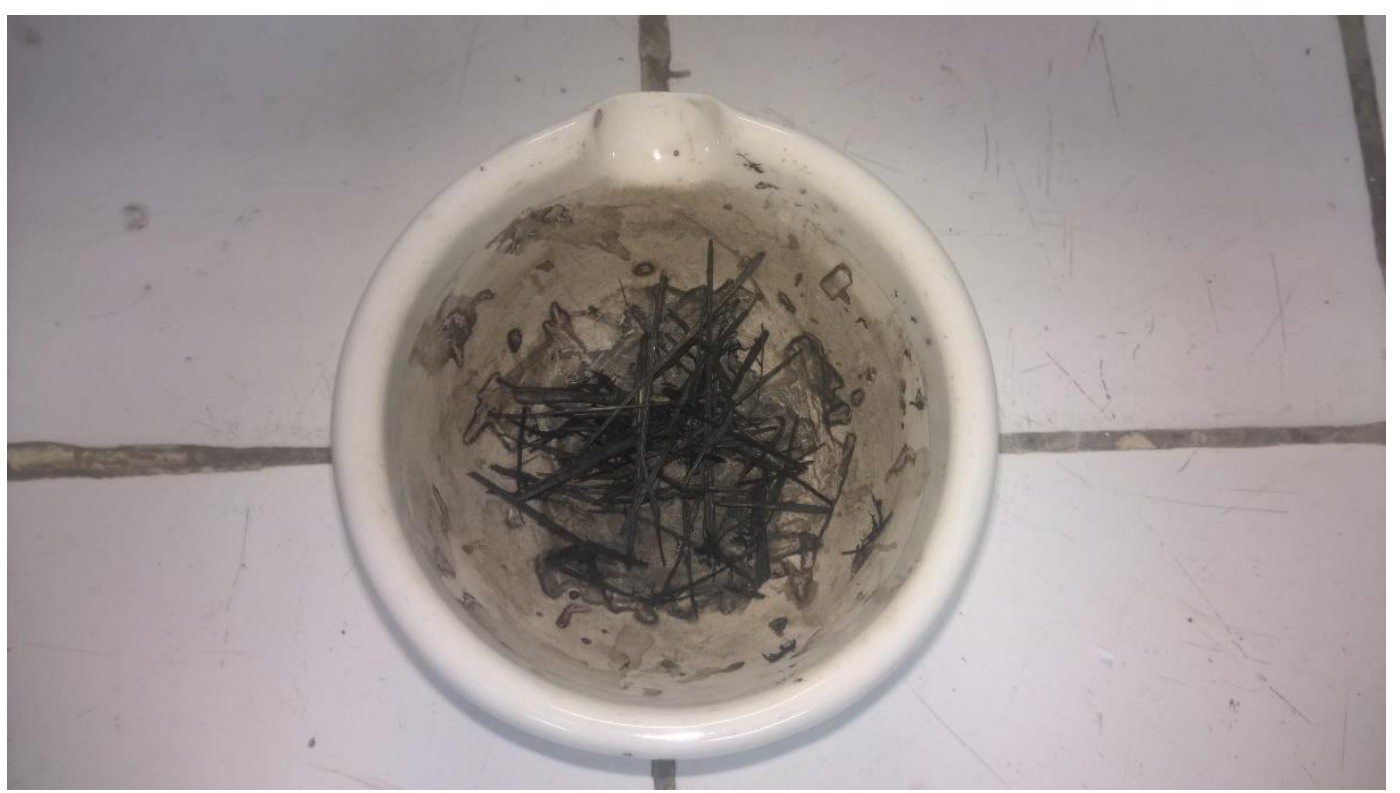

Figura 8 - Resultado da secagem do material

A última etapa foi a simples pesagem do material produzido, para comparação gravimétrica e consequente obtenção do rendimento do processo. 


\section{2}

\section{Funcionalização do composto rico em lignina}

Para a funcionalização do resíduo de produção de celulose (RPC), que foi o composto rico em lignina adotado para os testes, testaram-se oxidações com 3 ácidos distintos: nítrico $\left(\mathrm{HNO}_{3}\right)$, fosfórico $\left(\mathrm{H}_{3} \mathrm{PO}_{4}\right)$ e acético $\left(\mathrm{CH}_{3} \mathrm{COOH}\right)$. A escolha de tais agentes oxidantes deveu-se à preexistência de trabalhos publicados com esse procedimento feito sobre carvões, de modo que a atuação similar sobre o resíduo seria provável. A rota em si foi adaptada de Trompowsky et al. (2005).

O procedimento a seguir foi executado mais de uma vez, com quase todos os parâmetros repetidos identicamente, com a única diferença sendo o tipo de ácido usado.

Primeiramente, colocou-se um balão volumétrico, com um funil acoplado, sobre uma balança, adotando-se o peso desse conjunto como tara do equipamento. Então, pesaram-se $2 \mathrm{~g}$ de lignina.

Em seguida, dentro de um béquer, preparou-se uma solução de $25 \%$ do ácido em questão.

Com esses dois reagentes prontos, tentou-se fazer apenas a adição simples da solução ácida ao resíduo, dentro do balão. Porém, tal ação mostrouse inadequada, pois resultou em uma reação fortemente exotérmica, de modo que a mistura se projetou para fora do vidro (figura 9). Então, foi importante o registro de que o procedimento não deveria ser feito dessa maneira. 


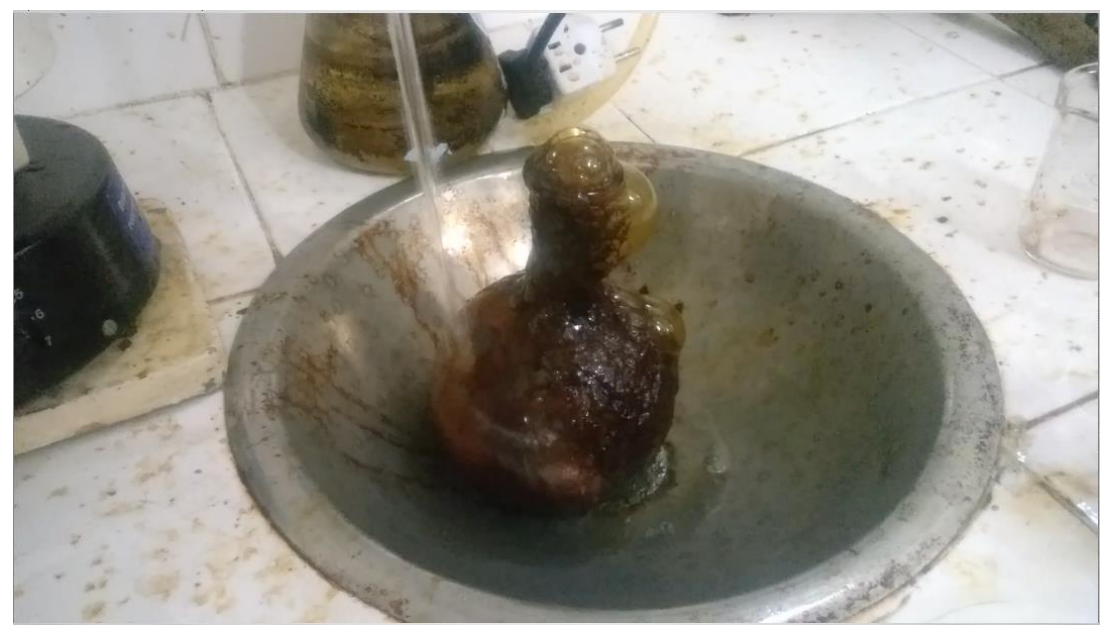

Figura 9 - Projeção da mistura de solução ácida e resíduo

Para evitar o problema supracitado, foram tomadas 3 precauções. A primeira foi garantir que a quantidade de lignina usada não fosse grande demais, motivo pelo qual se adotaram apenas $2 \mathrm{~g}$. A segunda foi fazer a mistura por gotejamento, colocando-se a solução ácida em um balão suspenso adequado para tal. A terceira e mais importante medida foi preparar um banho de gelo para o balão onde ocorreria a mistura dos reagentes. Para isto, usou-se um béquer de $1 \mathrm{~L}$, dentro do qual coubesse o balão, adicionou-se água até uma pequena altura, de modo que o balão não ficasse flutuando, e se acrescentaram cubos de gelo à água. $\mathrm{O}$ resultado foi o conjunto exibido na figura 10: 


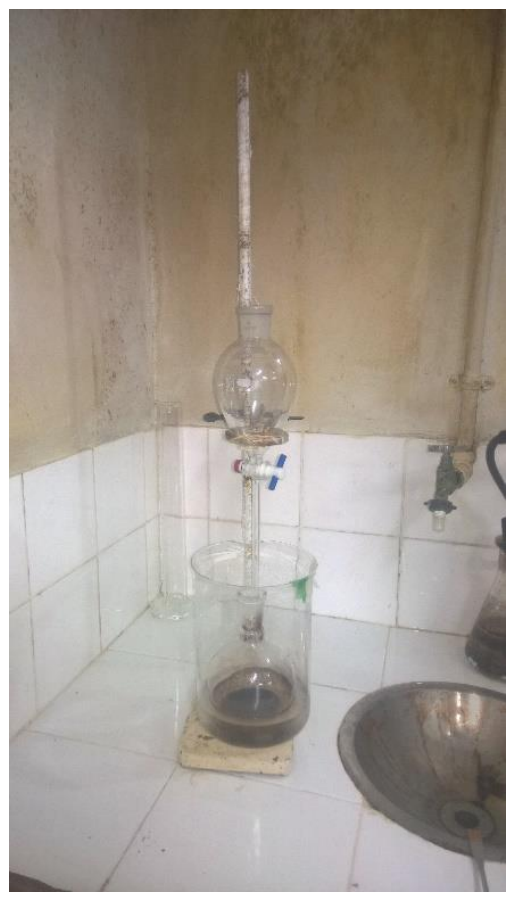

Figura 10 - Sistema de mistura da solução ácida ao resíduo

Após a finalização do gotejamento e a espera de que a reação se estabilizasse, o balão com a mistura foi retirado do béquer, para ir à etapa seguinte, de refluxo. Para ela, usou-se uma chapa de aquecimento e um recirculador de vidro, no qual água da torneira passava para garantir o arrefecimento. $\mathrm{O}$ resultado foi o aparato da figura 11 : 


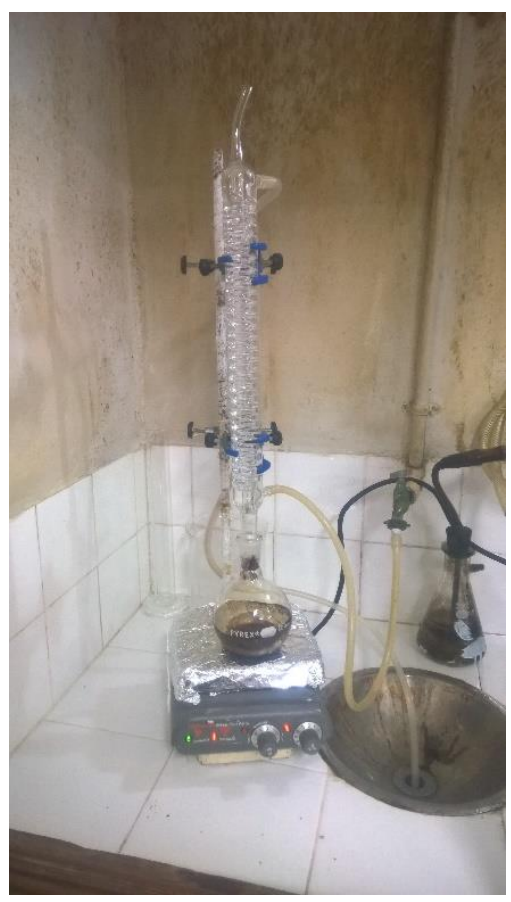

Figura 11 - Sistema de refluxo aplicado à mistura de lignina e resíduo

Em testes preliminares, buscou-se a ebulição da solução. Porém, isso também resultou na projeção, mostrando-se indevido. Então, usou-se a temperatura de $40^{\circ} \mathrm{C}$, sob refluxo, durante $4 \mathrm{~h}$. Ao fim desse período, desligou-se a chapa e se aguardou o resfriamento do balão.

A etapa subsequente consistiu na recuperação do material sólido, buscando-se separá-lo da solução ácida. Para tanto, a filtração a vácuo pareceu ineficiente, tanto por demandar mais tempo quanto por resultar em perdas de material durante o manuseio. Então, adotou-se a estratégia da centrifugação.

Para isso, foi usada a Centrífuga Digital Microprocessada Cientec CT6000. A solução de ácido e lignina foi acondicionada em 4 tubos Falcon, com volume complementado com água destilada para evitar desequilíbrio no peso. A centrifugação foi feita na velocidade de 3000 RPM, durante 10 minutos. A figura 12 ilustra o aspecto de uma das soluções ao fim do processo. 


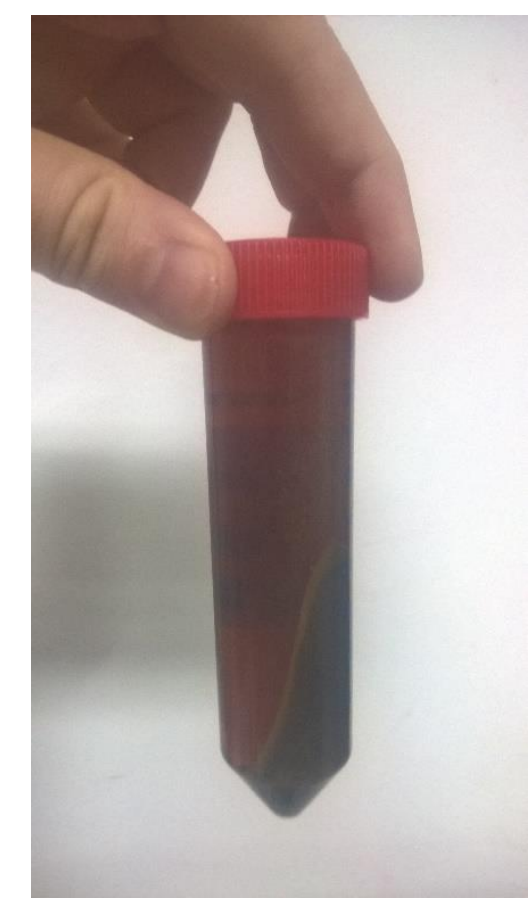

Figura 12 - Solução ao fim da centrifugação

Após isso, o líquido sobrenadante foi vertido sobre um béquer, para descarte.

Subsequentemente, fez-se a lavagem do material depositado em cada tubo Falcon. Para isso, o volume de cada tubo foi completado com água destilada e o conjunto foi agitado manualmente. Então, novamente, optou-se por fazer centrifugação, de modo a recuperar a lignina após esse contato com a água e a consequente purificação. A única diferença foi que, ao final da centrifugação, parte do sobrenadante foi coletada em um pequeno béquer para a determinação de $\mathrm{pH}$ com um pHmetro, e apenas o restante foi dirigido ao béquer maior, de descarte.

Para a adequada purificação do composto funcionalizado, essa sequência de lavagem e medição do $\mathrm{pH}$ foi repetida diversas vezes, até que $\mathrm{opH}$ se estabilizasse.

Finalizadas as lavagens, uma pequena suspensão do composto sólido com água foi colocada em um cadinho de porcelana, para secagem total em estufa, a $120^{\circ} \mathrm{C}$. As figuras 13 e 14 ilustram o início e o fim da secagem, respectivamente: 


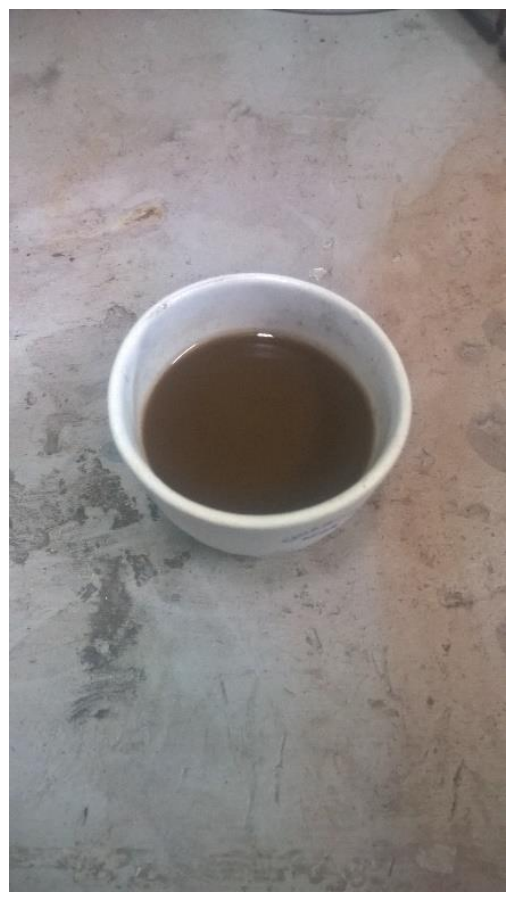

Figura 13 - Suspensão do composto sólido com água, encaminhada para

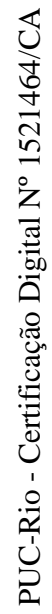
secagem

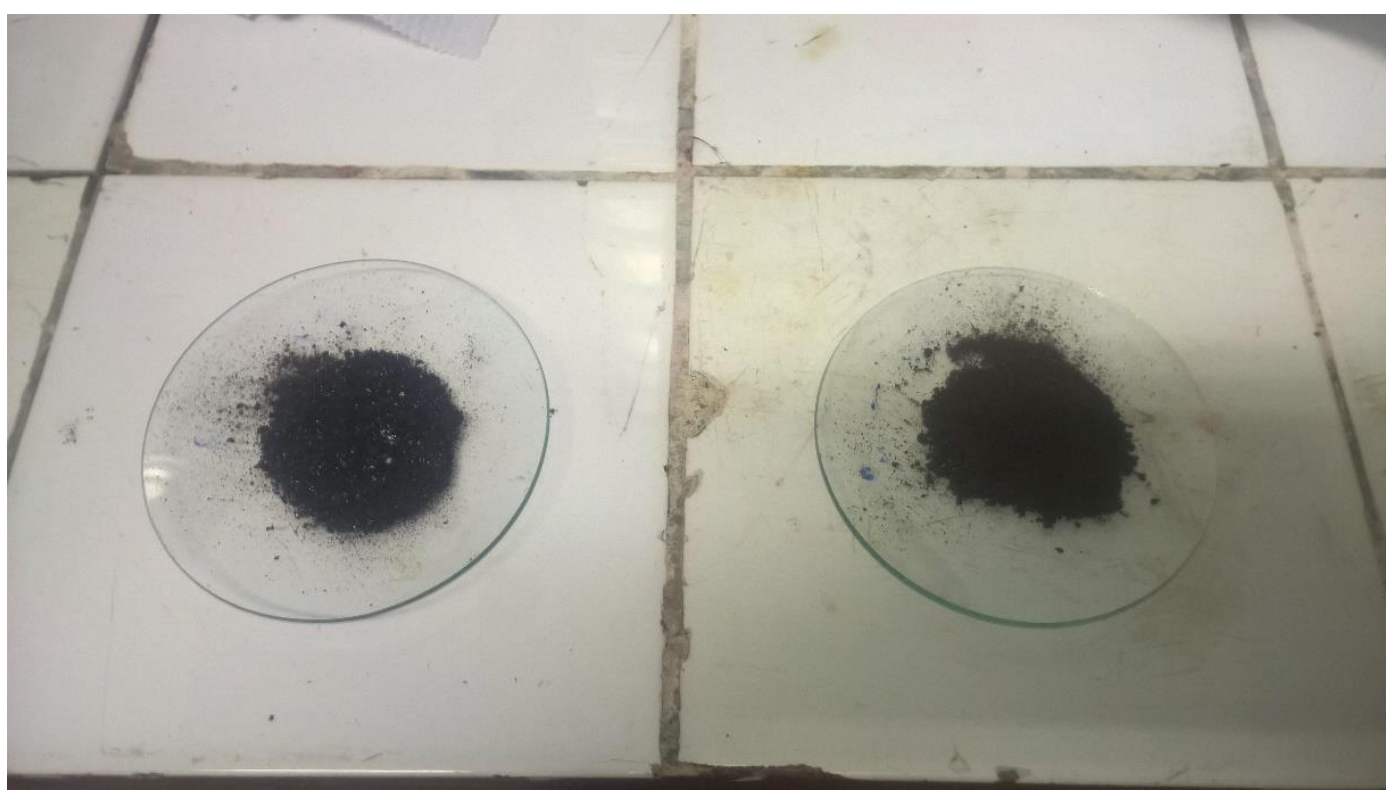

Figura 14 - Resultado da secagem

Por fim, o material sólido das paredes do cadinho foi raspado, colocado sobre um vidro de relógio e pesado, determinando-se, assim, o teor de recuperação de composto funcionalizado no processo. 


\section{3}

\section{Termogravimetria (TG)}

A análise termogravimétrica foi usada para observar a composição do Resíduo de Produção de Celulose (RPC), do Produto do Processo Klason sobre - Bagaço de Cana-de-Açúcar (PKBCA) e do Bagaço de Cana-de-Açúcar (BCA) original. Com isso, buscou-se determinar a porcentagem de cinzas, lignina e do conjunto celulose e hemicelulose em cada uma das 3 amostras.

Para tanto, usou-se uma balança termogravimétrica da marca Setaram, modelo Setsys Evolution, ilustrada na figura 15:

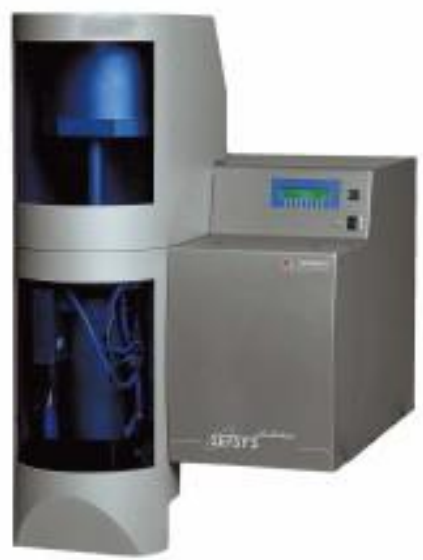

Figura 15 - Ilustração da balança termogravimétrica da marca Setaram, modelo Setsys Evolution (http://www.setaram.com/wp-content/uploads/2015/01/SETSYS -Evolution-closed1-185x230.jpg, acessado em 18/07/2017)

Os parâmetros do ensaio foram estes:

- Taxa de aquecimento: $10^{\circ} \mathrm{C} / \mathrm{min}$

- Temperatura final: $900^{\circ} \mathrm{C}$

- Gás injetado: Nitrogênio

- Fluxo de gás: $100 \mathrm{~mL} / \mathrm{min}$ 


\section{4 \\ Microscopia Eletrônica de Varredura (MEV) e Espectroscopia de Raios X por Energia Dispersiva (EDS)}

Para uma melhor caracterização de materiais usados neste trabalho, optou-se por usar as técnicas Microscopia Eletrônica de Varredura (MEV) e Espectroscopia de Raios X por Energia Dispersiva (EDS). A primeira teve por objetivo observar com mais detalhes $o$ aspecto dos materiais e identificar, se possível, suas rugosidade e porosidade, que seriam propriedades benéficas aos mecanismos de adsorção, que se esperam do material. A segunda, por sua vez, visa a informar os elementos químicos presentes. Ambas as técnicas são feitas no mesmo equipamento, sendo esse o motivo de serem abordadas simultaneamente neste texto.

Foram analisadas 6 amostras:

- Bagaço de cana-de-açúcar (BCA)

- Produto do Processo Klason sobre o Bagaço de Cana-de-Açúcar (PKBCA)

- Resíduo de Produção de Celulose (RPC)

- Resíduo de Produção de Celulose Funcionalizado por Ácido Nítrico (RPCAN)

- Resíduo de Produção de Celulose Funcionalizado por Ácido Fosfórico (RPCAF)

- Resíduo de Produção de Celulose Funcionalizado por Ácido Acético (RPCAA)

A análise das amostras BCA e PKBCA foi feita no Microscópio de Bancada Hitachi TM1000, enquanto as demais foram no Microscópio de Bancada Hitachi TM3000 e no EDS Swift ED3000. Ademais, novas imagens do RPC e do RPCAA foram feitas, no Microscópio JEOL JSM 6701F, do tipo MEV-FEG; pois pareceu importante fazer imagens mais detalhadas do material original, RPC, e do que mais apresentou alterações na superfície após o tratamento com ácido, que foi o RPCAA.

Previamente às análises, as amostras foram secas em estufa, a $100^{\circ} \mathrm{C}$, durante $6 \mathrm{~h}$. Isso foi feito para evitar que a umidade interferisse nos estudos. 
Então, para cada amostra, uma pequena quantidade foi colocada sobre uma fita de carbono e introduzida no equipamento.

No MEV, buscou-se o máximo aumento possível sem que se perdesse a qualidade da imagem. Para ilustrar o material de forma mais completa, registraram-se também imagens com ampliações menores que a máxima, formando-se um conjunto de figuras para cada amostra.

O EDS foi feito logo depois do MEV. Caso o feixe de elétrons do equipamento interagisse com a fita de carbono e com o porta-amostras que estavam sob o material, a leitura seria errônea, pois os elementos dessas 2 regiões não devem ser medidos, devendo apenas constar no resultado os elementos da amostra. Para evitar esse problema, as amostras foram convertidas em pastilhas, usando-se uma prensa, de modo que o volume de interação da análise ficasse contido apenas na pastilha, não interagindo com as regiões indesejadas que ficam abaixo dela. Como as amostras eram homogêneas, estima-se que o resultado para pontos específicos represente bem a totalidade do material.

\section{5}

\section{Espectroscopia no infravermelho por transformada de Fourier (FTIR)}

Fizeram-se análises de espectroscopia no infravermelho por transformada de Fourier (ou FTIR, conforme o nome em inglês "Fourier transform infrared Spectroscopy") sobre 4 diferentes materiais: o Resíduo de Produção de Celulose (RPC) e suas variantes funcionalizadas por ácido nítrico (RPCAN), ácido fosfórico (RPCAF) e ácido acético (RPCAA). O objetivo foi detectar, na superfície da matéria, os grupos funcionais oxigenados carboxila, carbonila e hidroxila.

O equipamento usado foi da marca PerkinElmer, modelo Frontier, exibido na figura 16. 


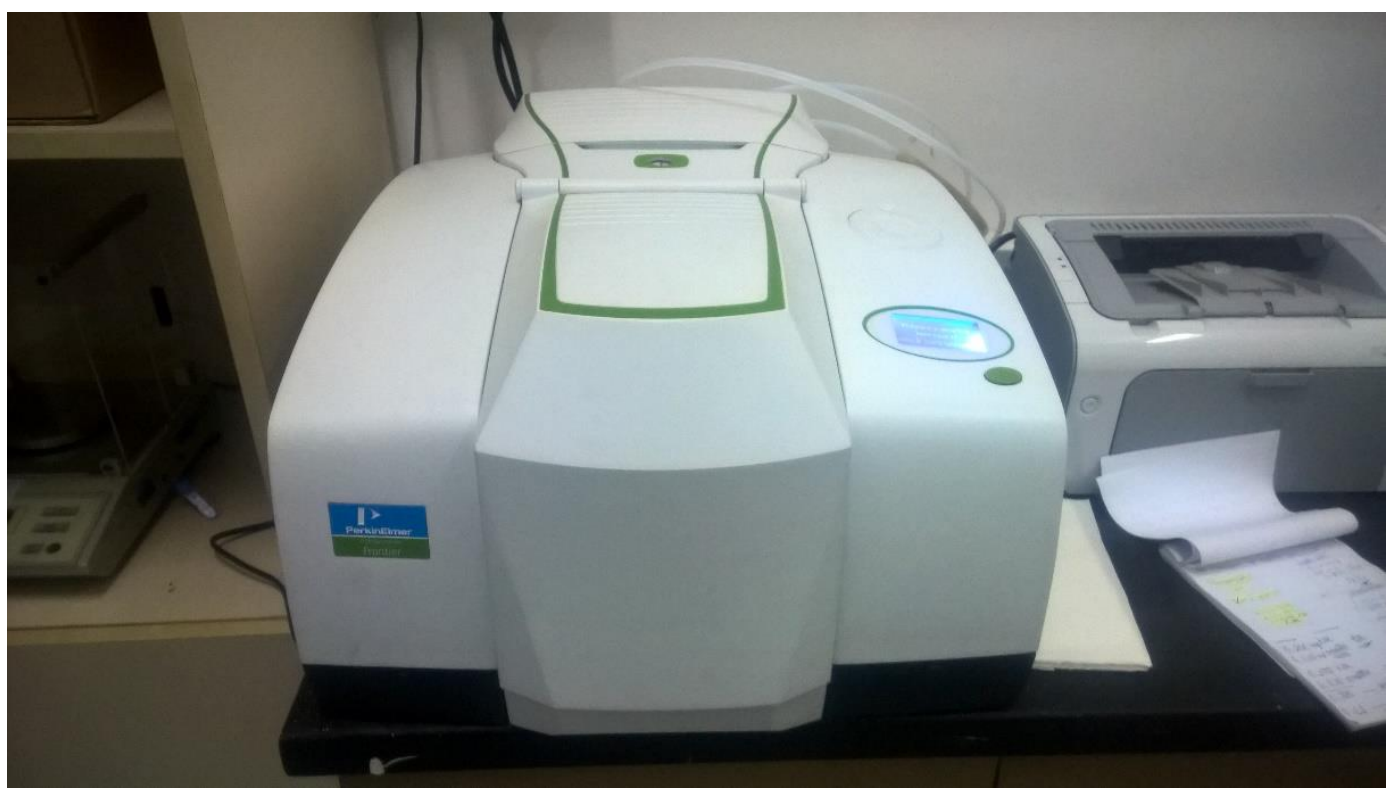

Figura 16 - Equipamento de FTIR da marca PerkinEImer, modelo Frontier.

Para cada amostra, o ensaio teve início com a pesagem de $190 \mathrm{mg}$ de brometo de potássio $(\mathrm{KBr})$. Em seguida, acrescentou-se $10 \mathrm{mg}$ do material a ser analisado, de modo que a massa da mistura totalizasse $200 \mathrm{mg}$.

Subsequentemente, a mistura foi homogeneizada manualmente, com auxílio de um pilão, e encaminhada para uma prensa, conforme a figura 17.

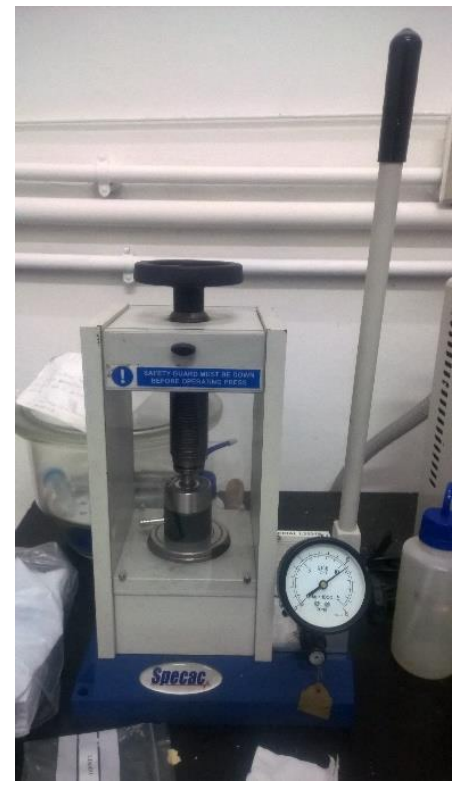

Figura 17 - Prensa para ensaio de FTIR 
Tal etapa resultou em uma pastilha sólida, que foi colocada dentro do equipamento, para se efetuar a leitura de FTIR propriamente dita.

\section{6}

\section{Caracterização mecânica do solo}

\subsection{1}

\section{Obtenção}

O solo usado nos experimentos foi extraído de um terreno do Campus da Pontifícia Universidade Católica do Rio de Janeiro, no local de latitude $22^{\circ} 58^{\prime}$ 52.482 " S e longitude $43^{\circ} 14^{\prime} 1.892$ " W. O procedimento consistiu em golpear o solo com uma picareta até obter amostras provenientes de uma profundidade aproximada de $10 \mathrm{~cm}$ e, logo em seguida, colocá-lo em sacos de plástico transparente, com auxílio de uma pá.

\subsection{2 \\ Preparo}

Já no laboratório, uma travessa metálica foi forrada com papel de jornal e o solo foi inteiramente disposto sobre a mesma. Então, fez-se um primeiro destorroamento, usando-se apenas as mãos, a fim de desagregar as partículas, facilitando-se procedimentos posteriores. Em seguida, o material foi seco em estufa, a $50^{\circ} \mathrm{C}$, durante $24 \mathrm{~h}$, obtendo-se o conjunto da figura 18 . 


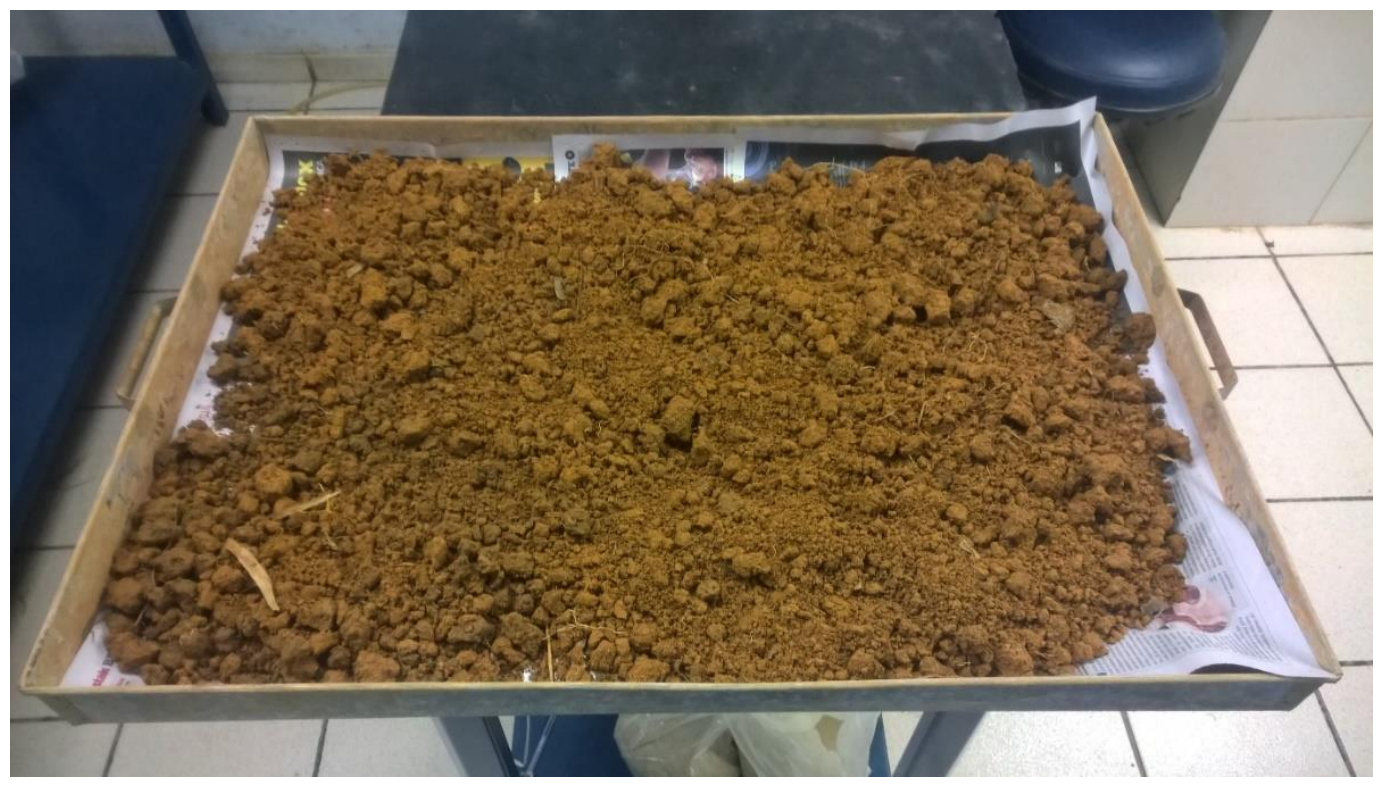

Figura 18 - Solo após secagem em estufa, a $50^{\circ} \mathrm{C}$, durante $24 \mathrm{~h}$.

Terminada a secagem, foi feito um segundo e definitivo destorroamento, aplicando-se golpes com um pilão, em ritmo lento o suficiente para evitar que os grãos do solo se quebrassem, a fim de se preservar suas características granulométricas naturais (figura 19).

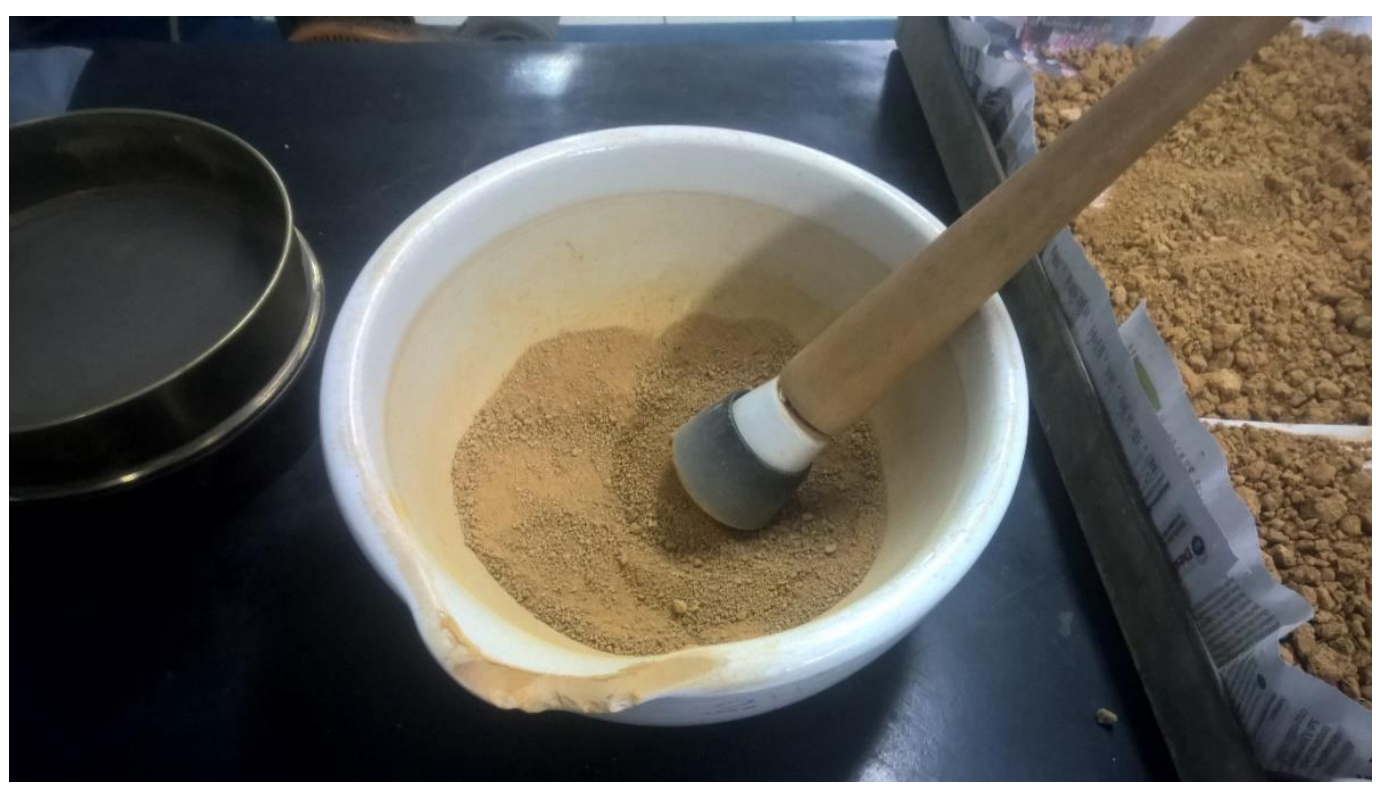

Figura 19 - Solo destorroado 


\subsection{3}

\section{Granulometria}

A descrição da granulometria do solo baseou-se na Norma Técnica NBR 7181. Primeiro, foram usadas 10 peneiras de diferentes tamanhos de malha, variando de Mesh $1 \frac{1}{2}(38,10 \mathrm{~mm})$ até Mesh $40(0,42 \mathrm{~mm})$, conforme a tabela 13, apresentada na seção Resultados. Depois, para observar as partículas mais finas, usou-se o procedimento de sedimentação, explicado mais adiante.

Inicialmente, pesaram-se $1560 \mathrm{~g}$ de solo destorroado. Subsequentemente, foi feita a pesagem individual de cada peneira, vazia. Registrados os valores, as peneiras foram empilhadas, com uma disposição sucessiva da com menor tamanho de poro (Mesh 40) no fundo até a de maior tamanho de poro (Mesh 1 $1 / 2$ ) no topo. O solo foi despejado no topo dessa pilha e o conjunto foi colocado em um agitador automático (figura 20) durante 15 minutos.

Por fim, as peneiras foram separadas e se pesou cada conjunto de "peneira + solo retido". Por subtração entre o peso desses conjuntos e das peneiras vazias, conheceu-se a massa de solo de cada faixa granulométrica.

Para conhecer a distribuição granulométrica dos grãos mais finos que 0,42 mm; que não ficam retidos em nenhuma das peneiras supracitadas, usou-se o procedimento de sedimentação. Para isso, o solo destorroado foi passado pela peneira Mesh 40, obtendo-se uma amostra de $50 \mathrm{~g}$. Ela foi misturada a $125 \mathrm{~mL}$ de solução do defloculante hexametafosfato de sódio, usando-se um misturador automático (figura 21) durante 10 minutos. 


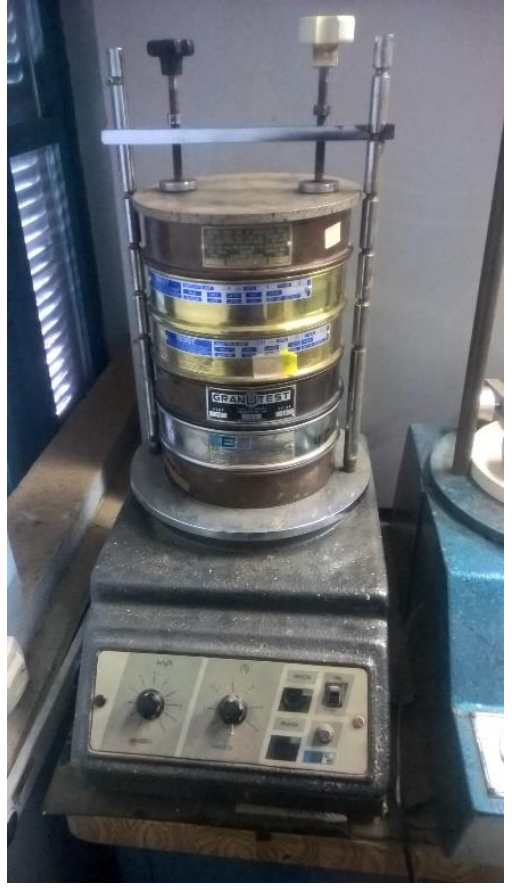

Figura 20 - Pilha de peneiras em agitador automático.

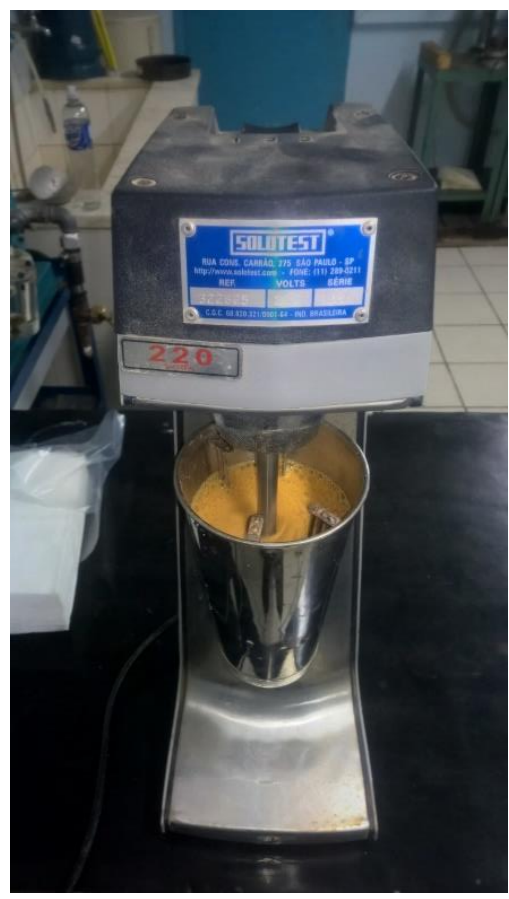

Figura 21 - Mistura de solo e defloculante em misturador automático.

Essa mistura foi colocada em uma proveta de $1000 \mathrm{~mL}$, completando-se esse volume com água destilada. Em uma outra proveta, colocaram-se apenas $1000 \mathrm{~mL}$ de água destilada, um termômetro e um densímetro (figura 22).

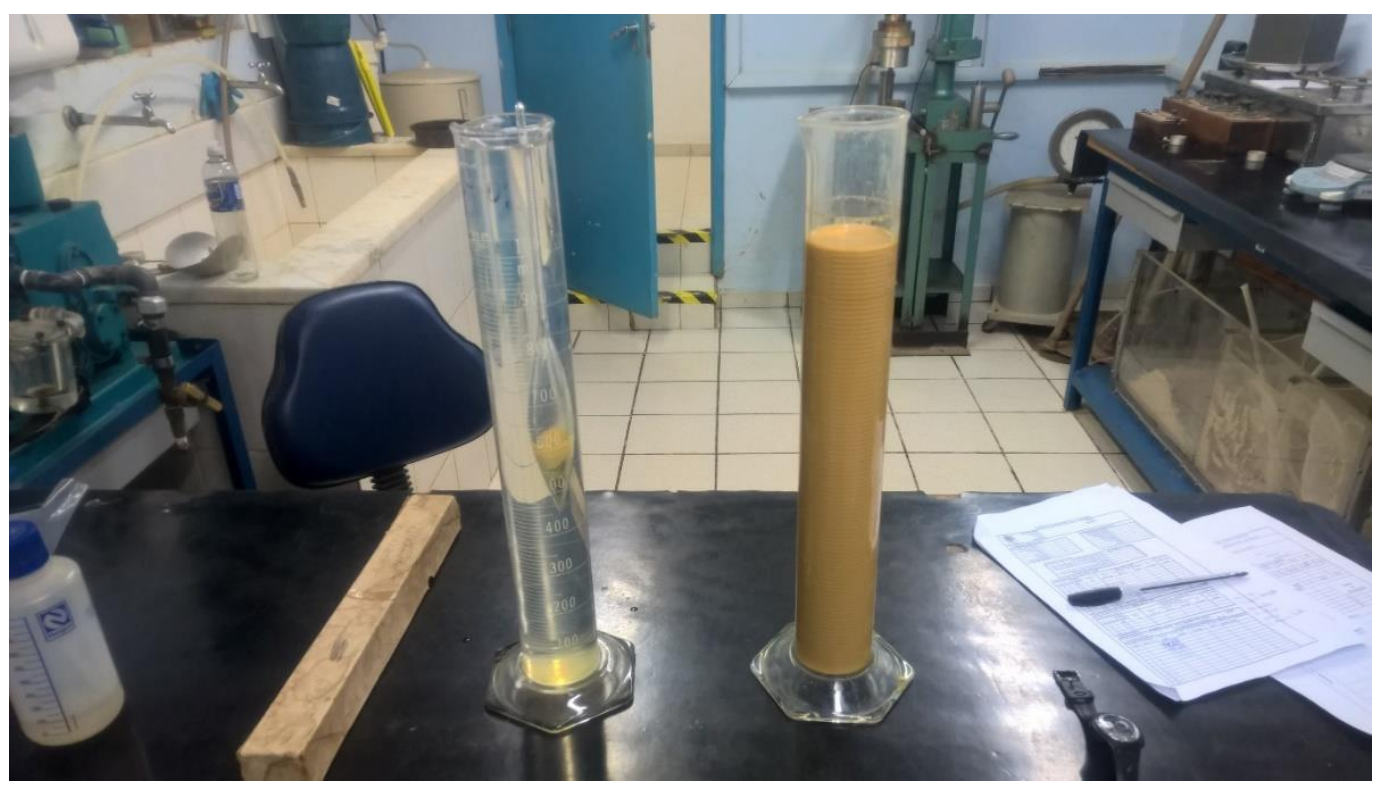

Figura 22 - Provetas no ensaio de sedimentação 
A bureta com o solo foi então tampada com papel-filme e agitada, manualmente, sendo alternadamente virada em $180^{\circ}$, de modo que o topo passasse a ser o fundo, e retornada à posição original. Esse processo durou 1 minuto, e, ao seu fim, retirou-se o papel-filme.

Então, colocou-se o densímetro na solução com solo, aguardando-se um tempo de estabilização de $30 \mathrm{~s}$, ao fim do qual se anotou a leitura da densidade. Em seguida, o densímetro foi devolvido para a bureta que continha apenas água destilada. A leitura seguinte, na bureta com solo, foi feita após mais $30 \mathrm{~s}$ (sendo esse tempo anotado como $1 \mathrm{~min}$, visto que a nomenclatura se refere ao tempo total transcorrido desde o início do ensaio). Sucessivamente, obtiveram-se 12 leituras, com a última sendo após 24 horas, conforme a tabela 15 da seção Resultados.

Após a última leitura, a solução com solo foi despejada sobre uma peneira Mesh 200 (0,074 mm), descartando-se o material passante. O conteúdo retido foi lavado, usando-se água corrente sobre a própria peneira, até que o líquido que saía da mesma tivesse aspecto límpido, indicando que não havia mais material a ser retirado por lavagem. Os grãos remanescentes na peneira foram, então, secos na estufa de $100{ }^{\circ} \mathrm{C}$ por $24 \mathrm{~h}$ e passados por uma sequência das peneiras Mesh 60, 100 e 200 (conforme a tabela 14 da seção Resultados), em procedimento análogo ao feito com 10 peneiras, explicado anteriormente.

\subsection{4}

\section{Umidade}

A determinação da umidade seguiu o Anexo da a Norma Técnica NBR 6457. Foram feitas as pesagens de uma cápsula vazia e da mesma cápsula preenchida pelo solo destorroado. Após isso, o conjunto foi seco em estufa a $100{ }^{\circ} \mathrm{C}$ por $24 \mathrm{~h}$. Por fim, pesou-se novamente o conjunto. $\mathrm{O}$ valor da umidade foi dado pelo quociente entre a massa de água, correspondente à diferença entre a massa do conjunto antes e após a secagem, e a massa de sólidos, expressa pela subtração entre a massa do conjunto após a secagem e a massa da cápsula vazia. 


\subsection{5}

\section{Limite de plasticidade}

A determinação do limite de plasticidade do solo seguiu a Norma Técnica NBR 7180 (ABNT, Rio de Janeiro, 1984). Primeiramente, um montante do solo destorroado atravessou a peneira Mesh 40, obtendo-se $1500 \mathrm{~g}$ de material passante. Então, foi tomada uma amostra de $200 \mathrm{~g}$, colocada sobre uma concha metálica. Acrescentou-se água, em cerca de $10 \mathrm{~mL}$, ao solo, e a mistura foi homogeneizada com auxílio de uma espátula (figura 23).

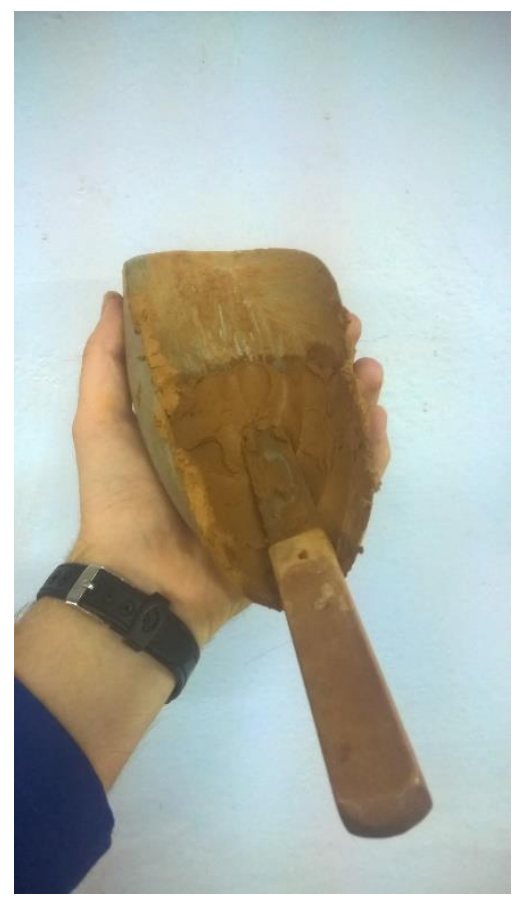

Figura 23 - Homogeneização do solo para ensaio de limite de plasticidade

Após isso, uma porção da mistura foi colocada sobre uma placa de vidro e, com as mãos, moldou-se um fino rolo, o qual foi comparado a um gabarito metálico (figura 24). Quando o rolo tornava-se mais fino que o gabarito sem que houvesse ruptura no solo, a amostra era devolvida à concha, e todo o solo era rolado sobre a palma da mão, para que a umidade fosse reduzida, e novamente homogeneizado com a espátula. Após isso, fazia-se novamente o fino rolo de solo, repetindo-se o procedimento supracitado. Nas vezes em que, diferentemente, o rolo rompia-se antes de chegar à espessura do gabarito, a 
amostra retornava à concha e o solo recebia mais água, era novamente homogeneizado com a espátula e se reiniciava o procedimento de o rolar sobre a placa de vidro e comparar com o gabarito.

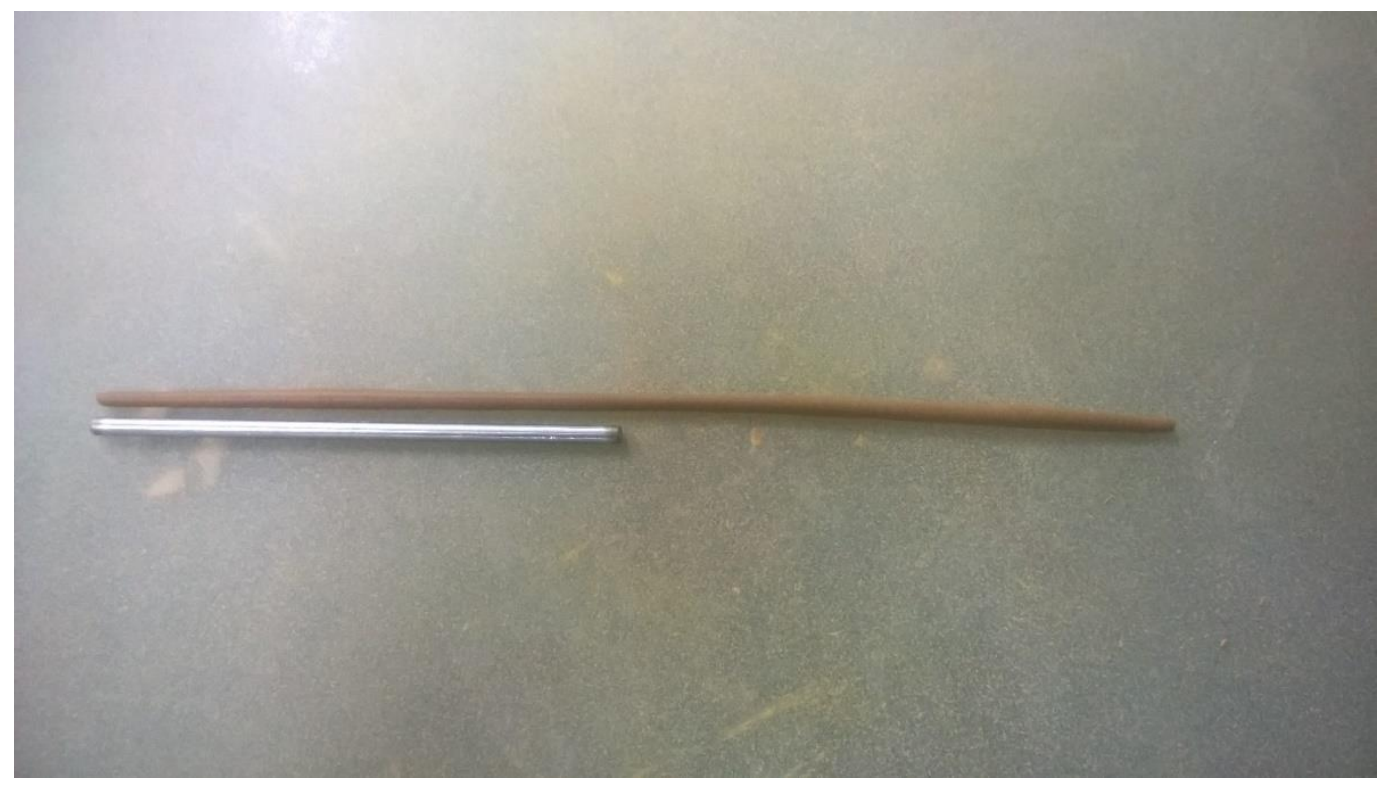

Figura 24 - Ensaio de limite de plasticidade

No final do processo, obteve-se um rolo de solo de espessura idêntica à do gabarito. Nessa situação, o rolo foi dividido em três partes e cada uma foi acondicionada em uma cápsula metálica. Cada uma dessas partes teve sua umidade determinada, conforme o procedimento anteriormente explicado, e a média dos três valores de umidade corresponde ao limite de plasticidade.

\subsection{6}

\section{Limite de liquidez}

O ensaio do limite de liquidez baseou-se na Norma Técnica NBR 6459 (ABNT, Rio de Janeiro, 1984). O solo usado foi o remanescente do teste de plasticidade, visto que, por definição, o limite de liquidez corresponde a uma umidade maior que a do limite de plasticidade (Pinto, 2006), sendo prudente iniciar o incremento de água a partir da amostra que está na umidade do limite de plasticidade. Assim, acrescentou-se mais água, em volume próximo a $10 \mathrm{~mL}$, 
ao solo, e o conjunto foi homogeneizado pela espátula. Em seguida, a mistura foi posta no prato do equipamento especificado pela NBR 6459 (ABNT, Rio de Janeiro, 1984), e foi feito um corte no solo com um cinzel (figura 25). No presente trabalho, o equipamento era automático, dando golpes no prato de maneira autônoma. Então, foi anotado o número de golpes necessário para que as duas metades do solo se tocassem, e uma amostra retirada da região central, no contato entre as metades, foi encaminhada para determinação da umidade. Tal sequência de operações foi repetida até que se obtivessem cinco valores de umidade, uniformemente distribuídos na faixa de 10 a 50 golpes. Caso fosse necessário obter um valor de umidade com número de golpes menor que o recém medido, o solo recebia mais água e uma nova sequência dessas operações era feita. Caso fosse necessário um maior número de golpes, a mistura era seca sendo rolada com as mãos ou recebendo mais solo e a nova sequência era realizada.

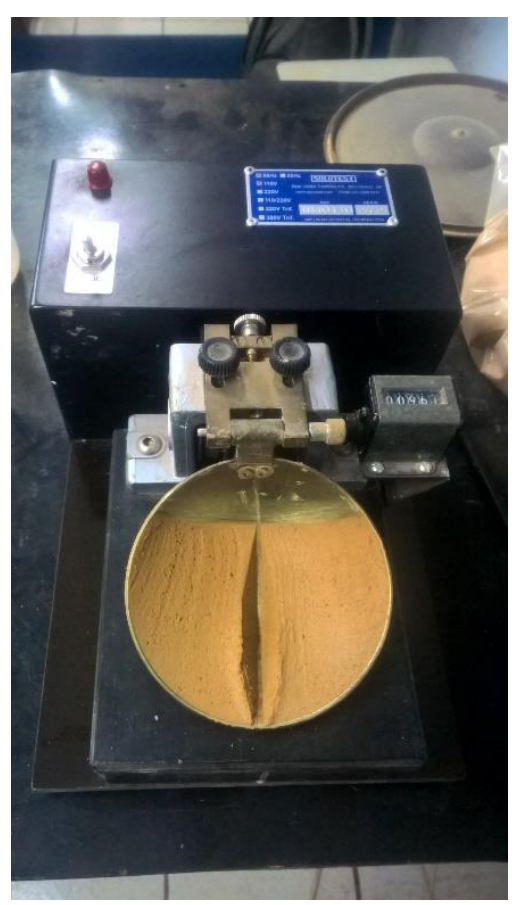

Figura 25 - Ensaio de limite de liquidez

A umidade média, obtida pelo gráfico descrito na Norma, no qual cada ponto corresponde a um par de número de golpes, no eixo horizontal; e umidade, no eixo vertical; representa o limite de liquidez. 


\subsection{7}

\section{Massa específica dos grãos}

O estudo da massa específica dos grãos do solo seguiu a Norma Técnica NBR 6508. Tomaram-se três amostras de $25 \mathrm{~g}$ do solo seco e destorroado, sendo cada uma posta dentro de um balão volumétrico de $250 \mathrm{~mL}$. Cada recipiente foi preenchido, com água destilada, até seu volume máximo.

Então, usou-se um sistema de vácuo, a fim de retirar as bolhas de ar ocluso presentes nos poros do solo. Aplicou-se o vácuo sobre cada balão volumétrico, com agitação manual e constante. Cada processo durou até que não houvesse mais saída visível de bolhas de ar e fosse possível ouvir um som das partículas sólidas colidindo com as paredes do frasco, tendo o tempo total sido $10 \mathrm{~min}$.

Em seguida, os três balões foram simultaneamente alocados em um recipiente com água, no qual estava posicionado um termômetro (figura 26). A finalidade disso foi estabilizar a temperatura dos grãos e da água, no valor que o termômetro indicava. Para tanto, o tempo transcorrido foi de $1 \mathrm{~h}$.

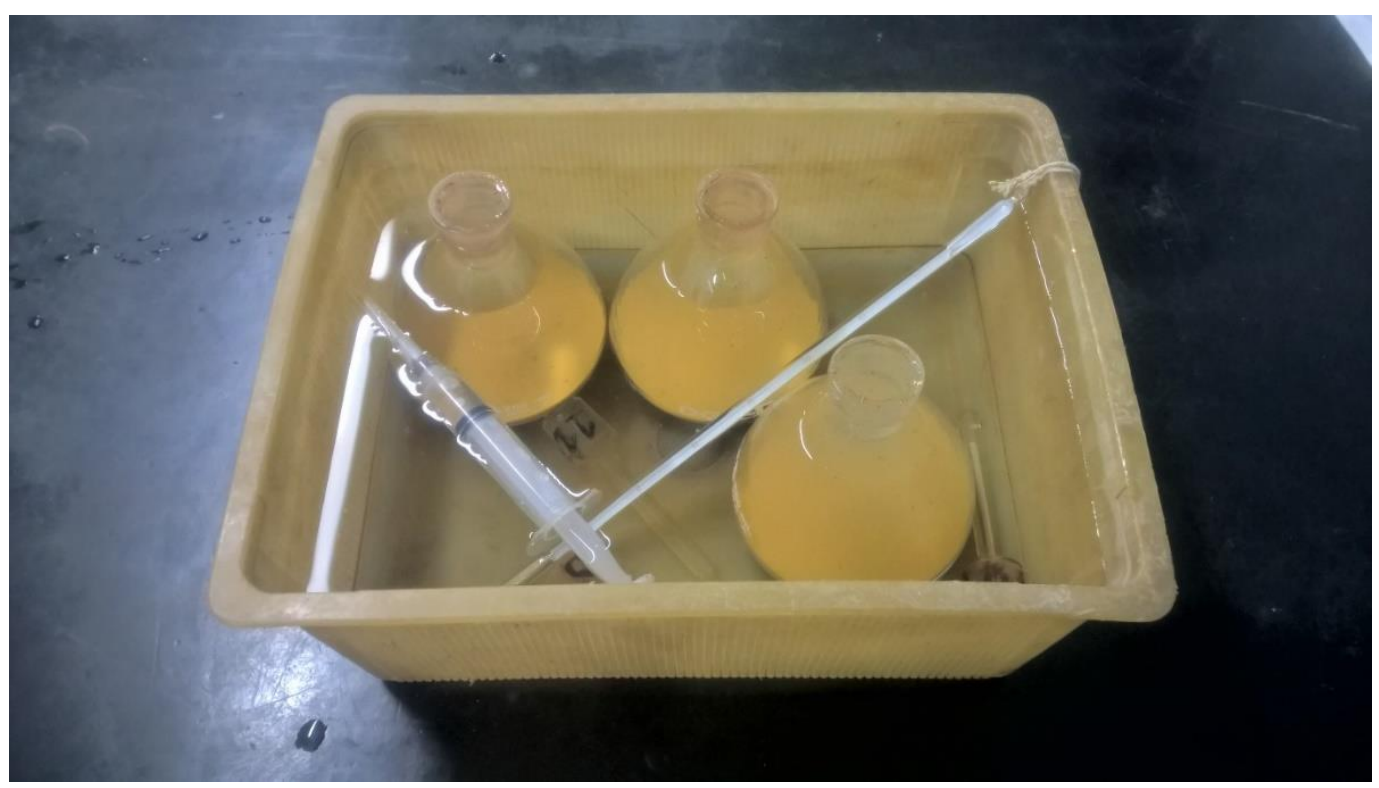

Figura 26 - Homogeneização de temperatura no ensaio de massa específica dos grãos 
Então, pesou-se cada conjunto de "balão + sólidos + água". Logo depois, os balões foram esvaziados e preenchidos unicamente com água destilada, proveniente do recipiente onde foi feita a supracitada estabilização de temperatura. Cada conjunto de "balão + água" foi pesado.

O valor da massa específica dos grãos corresponde ao quociente entre a massa dos grãos e o volume dos grãos.

$m e_{g}=m_{g} / v_{g}$

Onde $\mathrm{me}_{\mathrm{g}}=$ massa específica dos grãos, $\mathrm{m}_{\mathrm{g}}=$ massa dos grãos e $\mathrm{v}_{\mathrm{g}}=$ volume dos grãos.

O numerador é a própria massa total de solo seco e destorroado, de $25 \mathrm{~g}$, pois considera-se que o mesmo não contém água, por ter sido seco, e o ar não tem peso, de modo que a massa total é composta unicamente pela das partículas sólidas. O cálculo do denominador, porém, é mais complexo. Para isso, considerando-se o momento em que o balão está preenchido apenas por água, deve-se determinar qual é o volume do líquido que corresponde exatamente ao volume antes preenchido pelos sólidos. Tal volume é, por definição, o quociente entre a massa da água que ocupa esse volume e a massa específica da água na temperatura do ensaio. O valor dessa massa específica é tabelado, sendo de 0,997300 na temperatura do experimento, de $24{ }^{\circ} \mathrm{C}$. Para encontrar a massa da água, deve-se observar que a diferença entre as massas dos conjuntos "balão + sólidos + água" e "balão + água" representa o quanto os sólidos pesam a mais que a água ocupante do mesmo volume. Sabendo disso, basta subtrair a massa total dos grãos, de $25 \mathrm{~g}$, dessa diferença entre os conjuntos, de modo a extrair a massa extra dos sólidos e ter, dessa forma, a massa da água. Tendo a massa e a massa específica da água que ocupa o mesmo volume que os grãos, conhece-se seu volume, e, sabendo-se que ele é o mesmo dos sólidos, tem-se o volume dos sólidos. Então, basta dividir a massa dos sólidos pelo volume dos sólidos para conhecer a massa específica dos sólidos.

Portanto, para maior facilidade de uso, pode-se reescrever a equação para o cálculo da massa específica dos grãos do solo da seguinte maneira:

$$
m e_{g}=m_{s s d} /\left(\left(m_{s s d}-\left(m_{b+s+a}-m_{b+a}\right)\right) /\left(m_{a}\right)\right)
$$

Onde $\mathrm{me}_{\mathrm{g}}=$ massa específica dos grãos, $\mathrm{m}_{\mathrm{ssd}}=$ massa do solo seco e destorroado, $\mathrm{m}_{\mathrm{b}+\mathrm{s}+\mathrm{a}}=$ massa do conjunto "balão + sólidos + água", $\mathrm{m}_{\mathrm{b}+\mathrm{a}}=$ massa 
do conjunto "balão + água", me $_{\mathrm{a}}=$ massa específica da água na temperatura local.

\section{7}

\section{Capacidade de Troca Catiônica (CTC)}

A análise laboratorial da Capacidade de Troca Catiônica (CTC) foi feita como um indicador de fertilidade, comparando-se o solo puro com as misturas do mesmo com o Resíduo de Produção de Celulose (RPC), rico em lignina. Assim, usaram-se 4 tipos de amostra:

- Solo puro

- Solo com $1 \%$ de RPC em massa

- Solo com 5\% de RPC em massa

- Solo com $10 \%$ de RPC em massa

Tais amostras são detalhadas na seção Apêndice - Plano de Amostras.

Para maior confiabilidade nos dados, cada tipo de amostra foi testado em triplicata. Dessa forma, foram 12 testes ao todo.

Os ensaios foram realizados nos laboratórios da Embrapa Solos, situados no Rio de Janeiro-RJ. Então, seguiram a metodologia própria do órgão, disponível em detalhes no artigo de Donagemma et. al (2011).

Com isso, conhece-se a quantidade que o solo é capaz de fornecer de cada cátion aos vegetais, compondo-se as diversas informações da CTC, conforme o explicado na introdução deste trabalho. 


\section{5.}

\section{Resultados e Discussões}

\section{1}

\section{Obtenção do composto rico em lignina}

A rota química de obtenção, a partir do bagaço-de-cana, do composto rico em lignina resultou em um material sólido, já ilustrado pela figura 8 no fim da seção 4.1 .

Os valores da massa inicial, correspondente ao bagaço de cana-deaçúcar; da massa final, que é o composto rico em lignina; e do rendimento, que é o quociente entre as massas final e inicial, foram os seguintes:

\section{Massa Inicial (g) Massa Final (g) Rendimento}

10,00

1,01

$10,1 \%$

Tabela 1 - Resultado gravimétrico da obtenção do composto rico em lignina

Cada execução do processo demandou 1 dia de trabalho. Então, em face da baixa produtividade por dia trabalhado, da periculosidade do manejo de ácido sulfúrico e da necessidade de $104 \mathrm{~g}$ do composto para os ensaios de Limites de Atterberg e Capacidade de Troca Catiônica, conforme o Plano de Amostras; o processo foi considerado inadequado para abastecer as etapas subsequentes da pesquisa.

Por causa disso, optou-se por adquirir, por meio de doação de uma fabricante de celulose, um resíduo de produção de celulose rico em lignina. Esse material foi encaminhado aos testes de funcionalização por ácido, conforme descrito na seção 4.1.2. 


\section{2}

\section{Funcionalização da lignina}

A rota química de funcionalização do resíduo de produção de celulose (RPC) resultou em um material sólido, já ilustrado pela figura 14 no fim da seção 4.2 .

Para cada ácido usado, os valores da massa inicial, correspondente ao RPC; da massa final, que é o resíduo funcionalizado; e do rendimento, que é o quociente entre as massas final e inicial, foram os seguintes:

\begin{tabular}{|c|c|c|c|}
\hline Ácido & Massa Inicial (g) & Massa Final (g) & Rendimento \\
\hline Nítrico & 2,00 & 0,100 & $5,0 \%$ \\
\hline Fosfórico & 2,00 & 1,536 & $76,8 \%$ \\
\hline Acético & 2,00 & 0,983 & $49,2 \%$ \\
\hline
\end{tabular}

Tabela 2 - Resultado gravimétrico da funcionalização do resíduo

Assim, os únicos rendimentos considerados relevantes foram dos ácidos fosfórico e acético, visto que o do nítrico foi apenas de $5 \%$. Supõe-se que as perdas sejam devidas ao manuseio das soluções, sobretudo ao verter o líquido sobrenadante após as centrifugações; à dissolução do material; e à possível quebra do material pelo ácido. Nesta última suposição, o fato de o ácido nítrico ser o único dos 3 considerado um ácido forte pode ser a explicação para a mais intensa quebra.

Após essa análise gravimétrica, as amostras foram encaminhadas para a caracterização por microscopia (MEV) e infravermelho (FTIR).

Cada funcionalização demandou 1 dia de trabalho. Assim, considerando o alto tempo necessário para obter a quantidade suficiente para os ensaios de Limites de Atterberg e Capacidade de Troca Catiônica, não apenas as amostras do resíduo funcionalizado foram encaminhadas para a caracterização por microscopia (MEV) e infravermelho (FTIR), mas também as do resíduo original. Com isso, além de se observar se o material funcionalizado teria características promissoras para o uso como adsorvente, observou-se se o resíduo não 
funcionalizado já parecia suficiente para isso, de modo que os testes subsequentes poderiam ser feitos apenas com ele. Então, as amostras foram conduzidas para esses 2 tipos de ensaio.

\section{3}

\section{Termogravimetria (TG)}

Os ensaios de decomposição térmica das amostras resultaram em tabelas, nas quais se tinham diversas linhas e estas 4 colunas: temperatura, tempo, massa em porcentagem e massa em miligramas. Assim, foi possível conhecer o padrão de perda de massa de cada material. Para tanto, os dados foram convertidos em gráficos.

No caso do Resíduo de Produção de Celulose (RPC), proveniente do licor negro da fabricação de celulose a partir do eucalipto, foi também obtida a curva de termogravimetria diferencial (DTG), que correlaciona as temperaturas, no eixo das abscissas, à derivada matemática de cada ponto do gráfico de TG, no eixo das ordenadas, de modo a indicar com mais facilidade as temperaturas de mais intensa perda de massa.

A partir do traçado de cada um e da comparação com a literatura tocante ao tema, consultada nos trabalhos de Navarro (2011) e Gonçalves (2016), foram estimadas as composições de cada amostra em relação a umidade, cinzas, lignina e conjunto de celulose e hemicelulose; chegando-se às tabelas mostradas a seguir.

\subsection{1}

\section{Bagaço de cana-de açúcar (BCA)}

\section{- Curva de TG}

Massa Inicial: 21,26 mg 


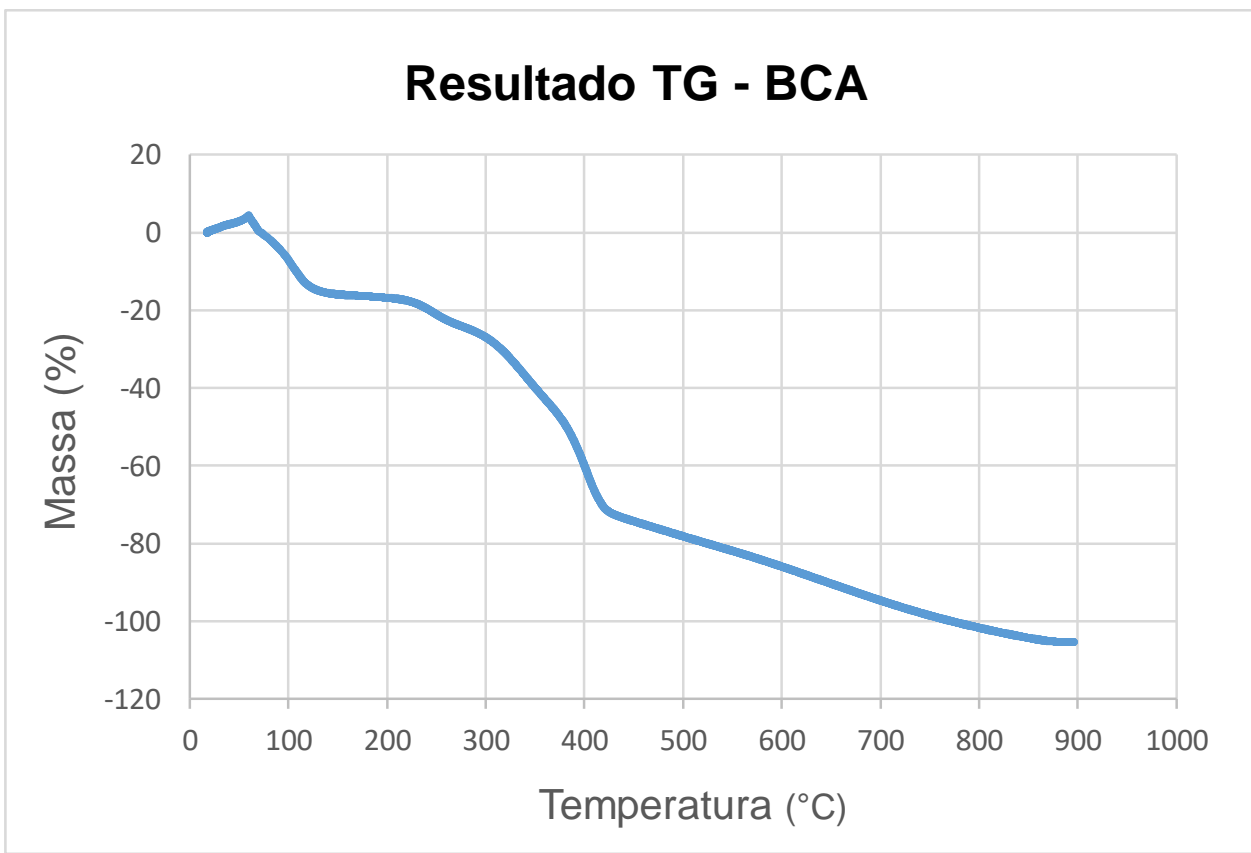

Gráfico 1 - Termograma do bagaço de cana-de-açúcar

\begin{tabular}{|l|r|}
\hline Componente & Massa (\%) \\
\hline Umidade & $14 \%$ \\
\hline Celulose e Hemicelulose & $58 \%$ \\
\hline Lignina & $28 \%$ \\
\hline Cinzas & $0 \%$ \\
\hline Total & $100 \%$ \\
\hline
\end{tabular}

Tabela 3 - Composição do bagaço de cana-de-açúcar interpretada a partir do termograma

Nesse termograma, podem-se observar 3 etapas distintas de decomposição.

A $1^{\text {a }}$ etapa está compreendida entre $0^{\circ} \mathrm{C}$ e cerca de $120^{\circ} \mathrm{C}$. Nota-se um comportamento atípico, pois há ganho de massa até certo instante, o que contraria a tendência de perda contínua de massa causada por ensaios de decomposição térmica. Isso sugere uma instabilidade no equipamento nesses primeiros momentos, de modo que, nos dois ensaios subsequentes, optou-se por excluir as temperaturas iniciais, de modo a ignorar essa faixa de aparente ganho de massa. 
No entanto, tal sequência de subida e descida da massa não afeta a interpretação dos resultados, dado que a variação vertical do gráfico é medida apenas pela subtração dos valores inicial, que é $0 \%$; e final, que foi de $-14 \%$, o que já possibilita estimar a quantidade de umidade perdida nesse período.

A $2^{2}$ etapa abrange a faixa até $426{ }^{\circ} \mathrm{C}$. De acordo com a literatura, essa parte indica o teor de celulose e hemicelulose, que foi então anotado na tabela.

Como não houve porcentagem remanescente após o fim do ensaio, parece que não havia cinzas, sendo todo o conteúdo restante composto por lignina. Então, tal valor foi também registrado na tabela.

\section{- Curva de DTG}

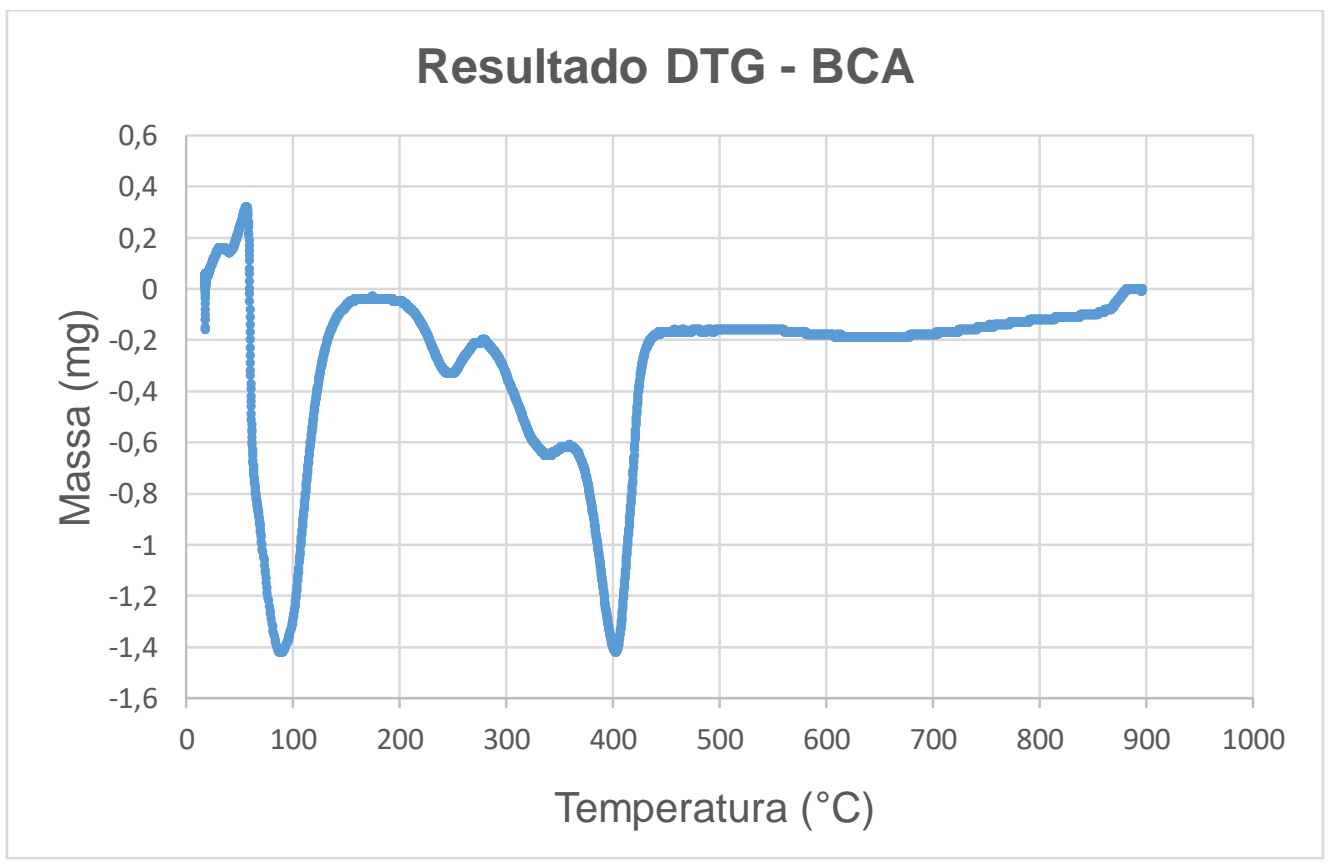

Gráfico 2 - Termograma diferencial do bagaço de cana-de-açúcar

Tal gráfico exibiu 3 regiões principais de máxima perda de massa. A primeira, que tem fim próximo a $100^{\circ} \mathrm{C}$, parece ser devida à perda de umidade. $\mathrm{A}$ segunda, que vai até $400^{\circ} \mathrm{C}$, aparenta ser a de perda de celulose e hemicelulose. A terceira, de $400^{\circ} \mathrm{C}$ em diante, pode ser devida à perda de lignina. 


\section{3 .2}

Produto do Processo Klason sobre o Bagaço de Cana-de-açúcar (PKBCA)

- Curva de TG

Massa Inicial: 73,31 mg

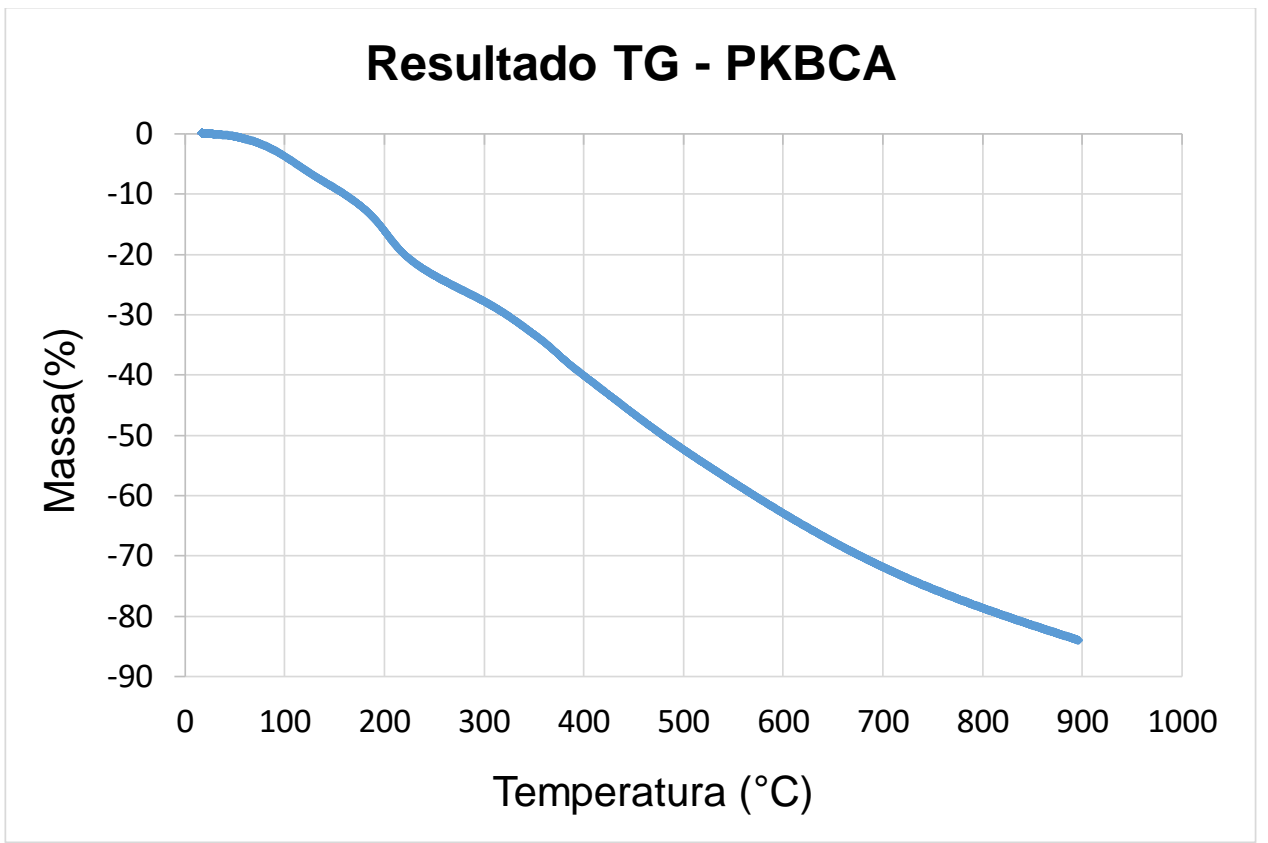

Gráfico 3 - Termograma do produto do processo Klason sobre o bagaço de cana-de-açúcar

\begin{tabular}{|l|r|}
\hline Componente & Massa (\%) \\
\hline Umidade & $6 \%$ \\
\hline Celulose e Hemicelulose & $17 \%$ \\
\hline Lignina & $62 \%$ \\
\hline Cinzas & $16 \%$ \\
\hline Total & $100 \%$ \\
\hline
\end{tabular}

Tabela 4 - Composição do produto do processo Klason sobre o bagaço de canade-açúcar interpretada a partir do termograma 
Aqui, novamente, há 3 faixas distintas de comportamento, correspondentes aos mesmos elementos do bagaço de cana. Deve-se citar, contudo, que esse gráfico se diferencia por não indicar a perda de 100\% da massa, apontando assim a existência de cinzas na amostra.

A $1^{\text {a }}$ etapa, que vai até $120^{\circ} \mathrm{C}$, sugere a existência de $6 \%$ de umidade.

Apesar de ser uma curva muito mais regular que a do bagaço, o gráfico revelou uma certa mudança de comportamento após $230{ }^{\circ} \mathrm{C}$, sugerindo que nesse ponto termine a faixa de celulose e hemicelulose.

A lignina, então, corresponde ao material decomposto desse limite até o fim, abrangendo uma ampla faixa de temperatura. Isso condiz com o esperado, visto que a amostra provém da conversão do bagaço pelo método Klason, de modo a ter um alto teor de lignina.

Por fim, o teor de cinzas é a fração mássica remanescente após a temperatura de $900^{\circ} \mathrm{C}$, que encerra o termograma.

\section{- Curva de DTG}

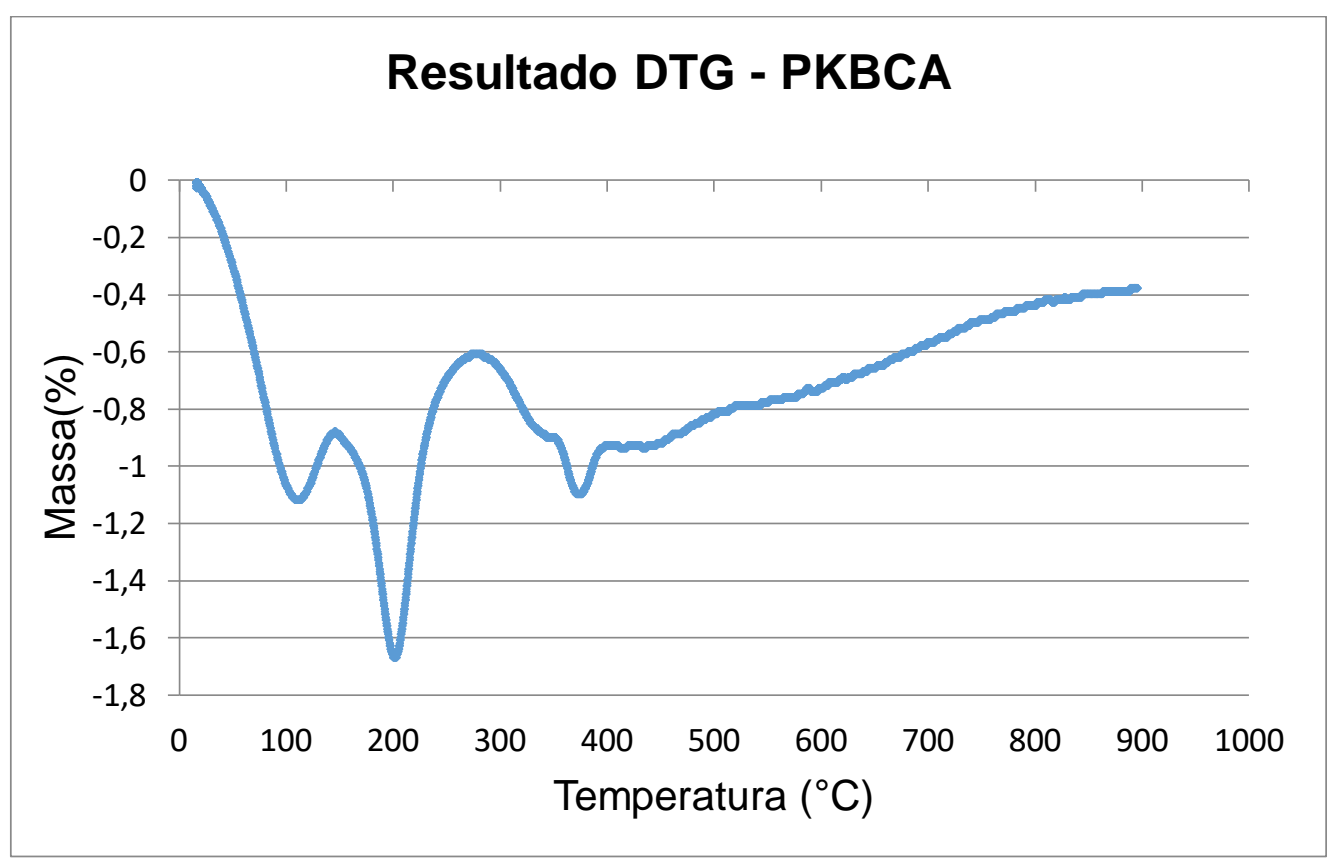

Gráfico 4 - Termograma diferencial do produto do processo Klason sobre o bagaço de cana-de-açúcar 
Tal gráfico exibiu 4 regiões principais de máxima perda de massa. A primeira, antes de $100^{\circ} \mathrm{C}$, parece ser devida a uma perda na umidade. A segunda, com pico em $120^{\circ} \mathrm{C}$, parece ser a de máxima perda de umidade. A terceira, entre $200^{\circ} \mathrm{C}$ e $400^{\circ} \mathrm{C}$, pode ser a de perda de lignina. A quarta, de $400^{\circ} \mathrm{C}$ em diante, possivelmente revela perda de mais lignina.

\subsection{3}

\section{Resíduo de Produção de Celulose (RPC)}

\section{- Curva de TG}

Massa Inicial: 49,5 mg

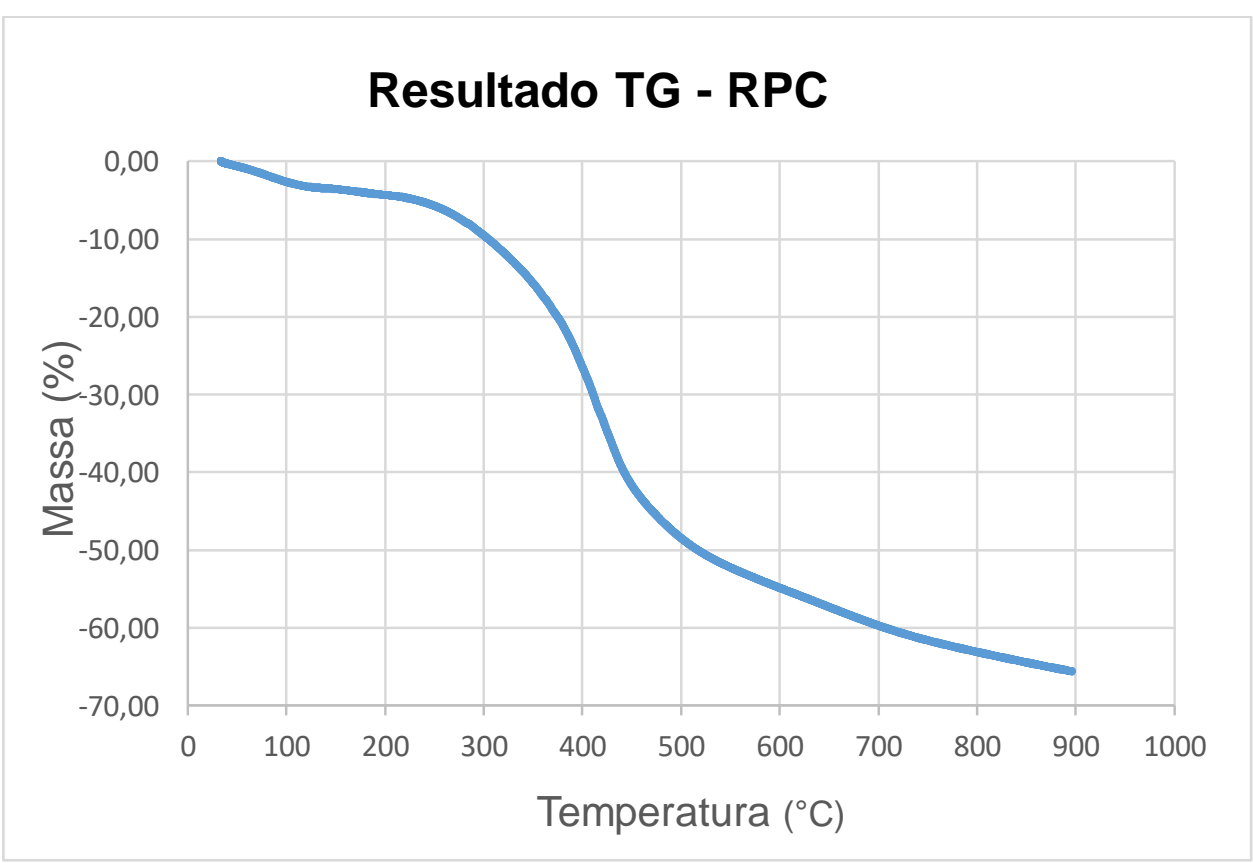

Gráfico 5 - Termograma do resíduo de produção de celulose

\begin{tabular}{|l|r|}
\hline Componente & Massa (\%) \\
\hline Umidade & $3 \%$ \\
\hline Celulose e Hemicelulose & $37 \%$ \\
\hline Lignina & $25 \%$ \\
\hline Cinzas & $34 \%$ \\
\hline
\end{tabular}




\section{\begin{tabular}{|l|r|} 
Total & $100 \%$ \\
\hline
\end{tabular}}

Tabela 5 - Composição do resíduo de produção de celulose interpretada a partir do termograma

A interpretação foi análoga à dos outros 2 gráficos, resultando também em 3 faixas e mais um teor de cinzas.

A $1^{\underline{a}}$ etapa, até cerca de $120^{\circ} \mathrm{C}$, mostra o teor de água.

A $2^{\mathrm{a}}$ etapa, que esse estende até cerca de $420^{\circ} \mathrm{C}$, revela o conteúdo de celulose e hemicelulose.

A partir dessa temperatura, pôde-se medir a quantidade de lignina, observando-se a curva até seu fim.

Subtraindo-se a massa total das 3 etapas dos $100 \%$ de massa existentes, obteve-se o teor de cinzas da amostra.

Tal análise diferenciou-se um pouco do esperado, por revelar um teor de lignina mais baixo que o da soma de celulose e hemicelulose. Isso aponta que o material não deve ser chamado diretamente de lignina de eucalipto, sendo mais conveniente a alcunha de Resíduo de Produção de Celulose a partir do eucalipto. Porém, o teor de cinzas mostrou-se muito mais elevado que no bagaço puro, o que se deve, provavelmente, ao carbono fixo. Assim, tal material apresenta-se como mais estável quimicamente do que a biomassa original, o que justifica seu uso no condicionamento de solos.

\section{- Curva de DTG}




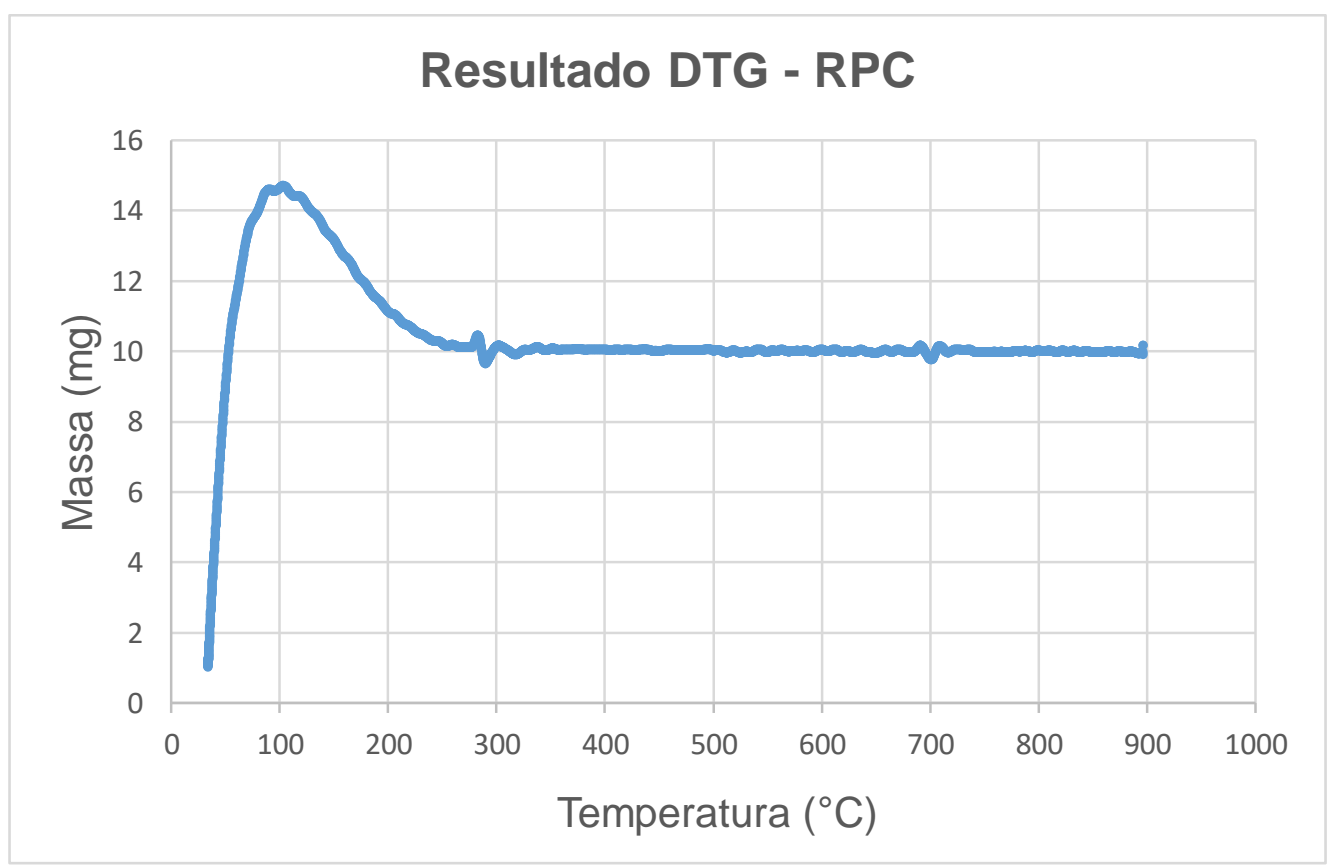

Gráfico 6 - Termograma diferencial do resíduo de produção de celulose

A curva de DTG não exibiu muitos pontos de máxima perda de massa, sugerindo um processo com notável regularidade. O único ponto de máximo relevante foi aos $100{ }^{\circ} \mathrm{C}$, ocasionado, provavelmente, pela acentuada perda de umidade.

\section{3 .4}

Considerações

A partir da análise termogravimétrica das 3 amostras, conclui-se que o BCA se destaca por não apresentar cinzas, tendo apenas umidade, celulose, hemicelulose e lignina; e por ter predomínio de celulose e hemicelulose.

A amostra PKBCA apresenta elevado teor de lignina, exibindo também quantidade considerável de cinzas.

O material RPC contém o mais elevado teor de cinzas, mas também exibe grandes quantidades de lignina, celulose e hemicelulose. 


\section{4 \\ Microscopia Eletrônica de Varredura (MEV) e Espectroscopia de Raios X por Energia Dispersiva (EDS)}

\section{4 .1}

\section{Microscopia Eletrônica de Varredura (MEV)}

O uso do Microscópio Eletrônico de Varredura (MEV) proporcionou as imagens mostradas a seguir.

Cabe dizer, inicialmente, que o material analisado não se mostrou um bom condutor de elétrons, de modo que os reteve fortemente durante a varredura, o que pode criar pontos inteiramente brancos na imagem e, consequentemente, prejudicar a visibilidade. Tal fato impediu que houvesse uma concentração muito grande dos elétrons em uma região que fosse muito específica, de forma que não foi possível ampliar muito as imagens em alguns casos.

Foi testada a obtenção de diversas imagens. Porém, para tornar esta apresentação mais concisa, apenas as mais relevantes de cada amostra serão exibidas.

\subsubsection{1}

\section{Bagaço de cana-de-açúcar (BCA)}

A imagem a seguir (figura 27) exibe uma região da amostra na qual pode ser visto um grão isolado. O aumento usado foi de 120 vezes (x120). 


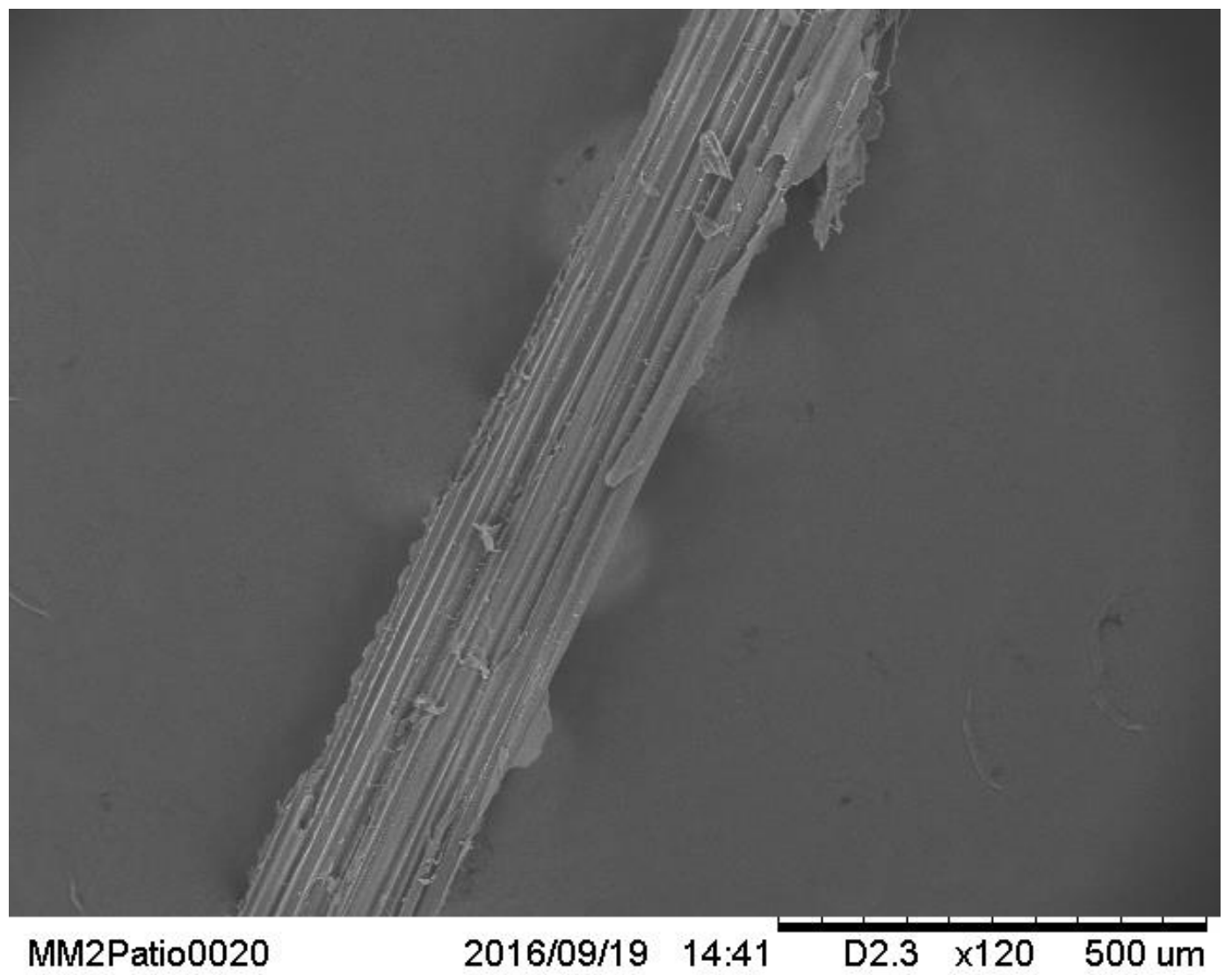

Figura 27 - Bagaço de cana-de-açúcar ampliado x120

Nela, pode-se ter uma noção inicial do aspecto do material. É importante observar que a superfície tem uma orientação em uma direção bem definida, sendo bastante lisa ao longo de cada fibra. As rugosidades ficam apenas entre uma fibra e outra, na direção perpendicular a elas.

A figura 28 mostra a mesma região, aumentada $\times 500$. 


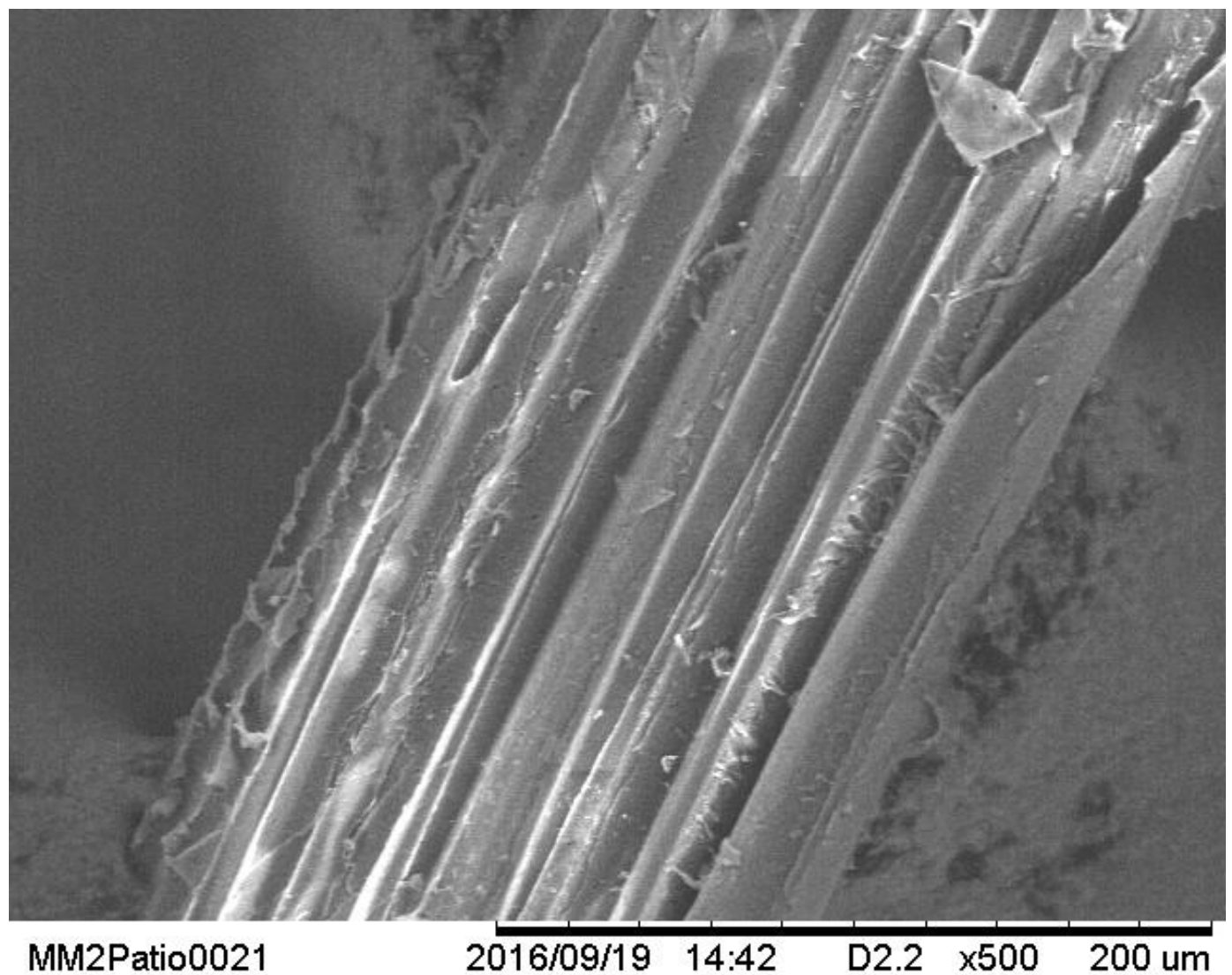

Figura 28 - Bagaço de cana-de-açúcar ampliado ×500

Nela, fica ainda mais notável que a superfície é predominantemente lisa. Isso sugere que a relação superfície-volume não seja muito alta, de modo que o contato do material com o meio externo não é muito grande.

A figura 29 mostra uma região diferente, também x120. 


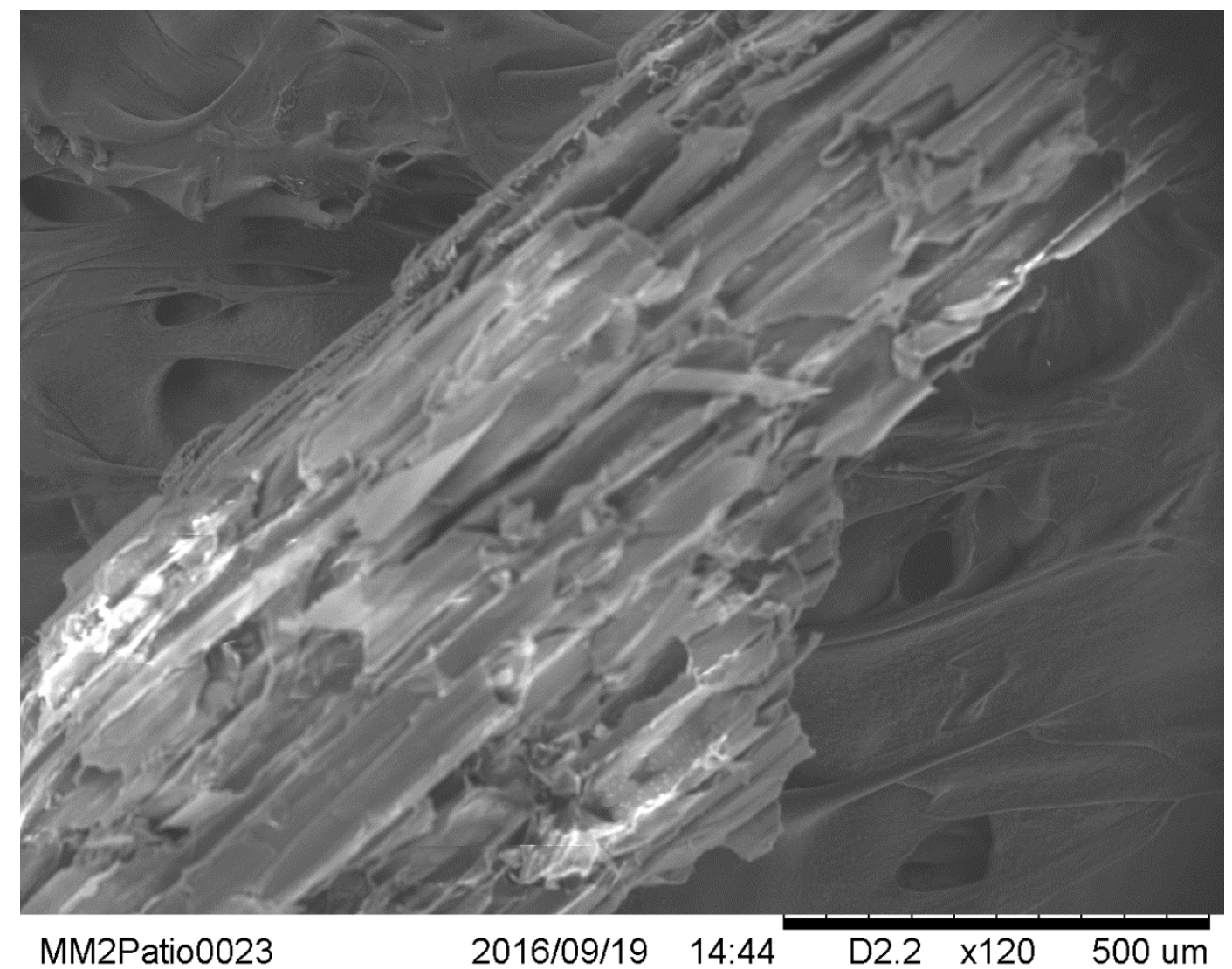

Figura 29 - Bagaço de cana-de-açúcar ampliado x120 em 2ª região

Apesar de um pouco mais irregular, a superfície assemelha-se muito à da primeira imagem (figura 28).

Assim, pode-se concluir que o bagaço de cana original tem superfície orientada de forma unidirecional e muito lisa. Esta última característica sugere baixa relação superfície-volume e pouco atrito com materiais que desloquem no contato com o grão. Logo, o bagaço, nesse estado, parece inadequado à adsorção de substâncias. 


\subsubsection{2}

\section{Produto do Processo Klason sobre o Bagaço de Cana-de-Açúcar (PKBCA)}

A primeira imagem (figura 30) mostra alguns grãos do material, com aumento $\times 120$.

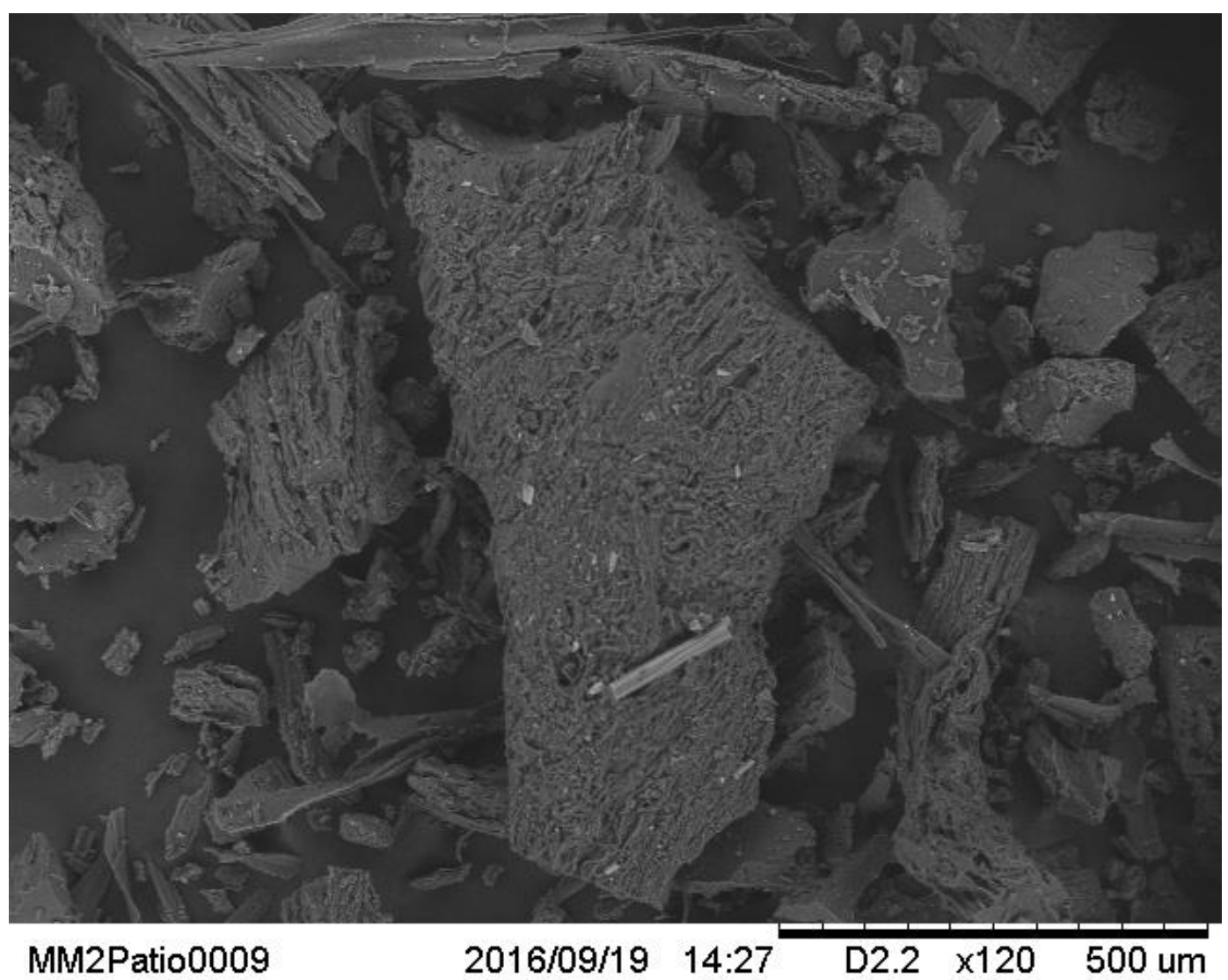

Figura 30 - Produto do processo Klason sobre o bagaço de cana-de-açúcar ampliado $\times 120$

Nela, pode-se ter uma noção inicial da amostra. Nota-se uma direção preferencial das fibras, mas os sulcos entre elas parecem mais numerosos e profundos do que no bagaço original. Além disso, alguns dos grãos não exibem orientação tão bem definida nas fibras, tendo uma rugosidade muito mais perceptível. Chama também a atenção o grande grão central e a irregularidade 
de sua superfície. Por isso, o mesmo foi ampliado até x1500, resultando na figura 31 .

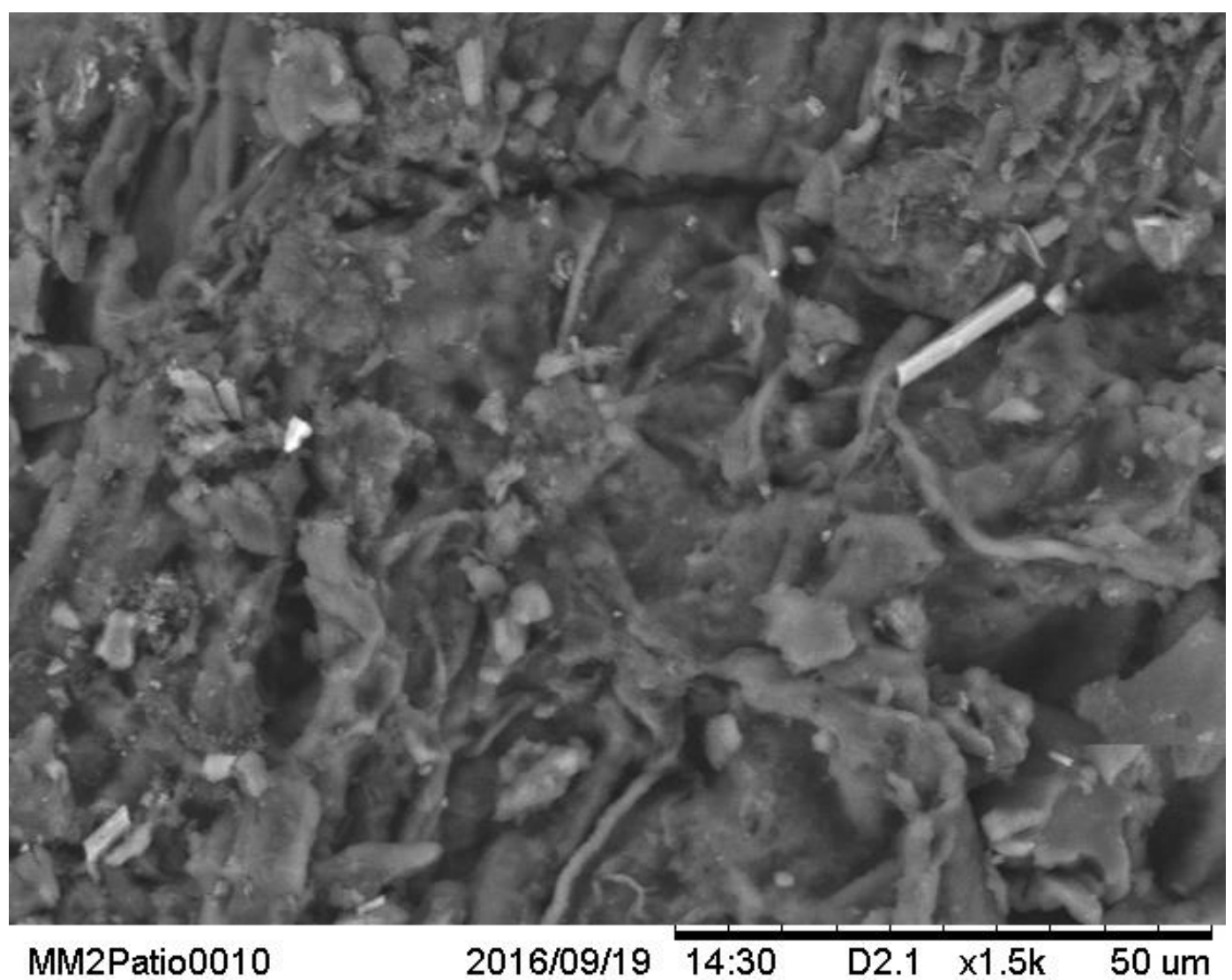

Figura 31 - Produto do processo Klason sobre o bagaço de cana-de-açúcar ampliado $\times 1500$

Tal figura denota a rugosidade da superfície do material e o fato de as fibras não estarem tão claramente orientadas em uma só direção. A rugosidade sugere uma grande relação superfície-volume e, consequentemente, uma maior área de contato do material com o meio externo.

A figura 32, com aumento de $\times 1000$, ilustra o grão menor presente à direita e acima do grão da figura 30 . 


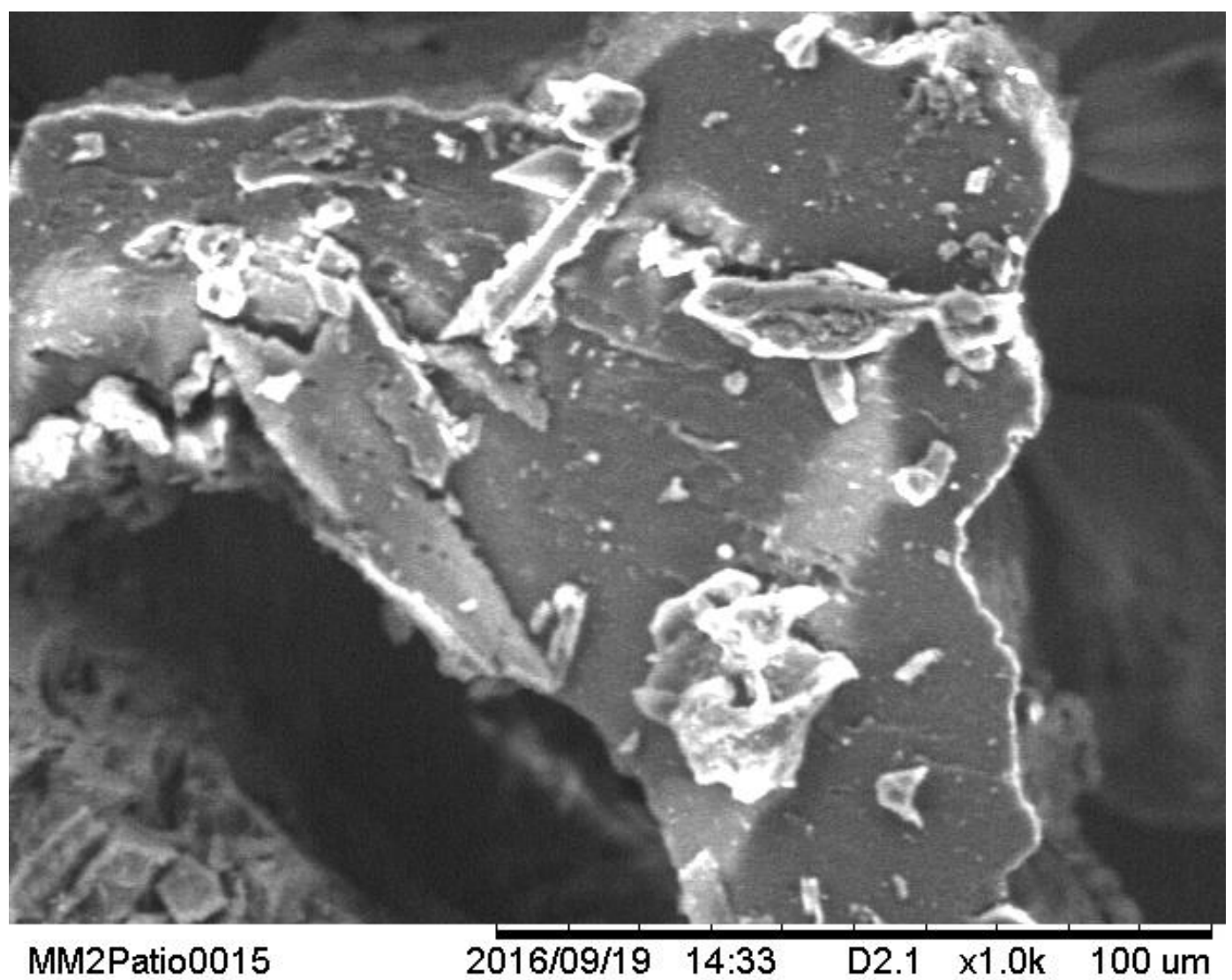

Figura 32 - Produto do processo Klason sobre o bagaço de cana-de-açúcar ampliado $\times 1000$

Esse grão parece ser uma secção transversal das fibras, pois não exibe a orientação das mesmas. Sua superfície mostra-se mais lisa, o que sugere que, mesmo com o tratamento Klason, a rugosidade dessa secção não foi aumentada de forma que seja perceptível nesse grau de ampliação.

Dessa forma, nota-se que o produto do processo Klason sobre o bagaço resulta em um material com superfície distinta da original. A mais notável diferença é a grande rugosidade vista nas secções longitudinais das fibras, tanto entre uma fibra e outra quanto na direção que as acompanha. Nas secções transversais, porém, veem-se superfícies muito lisas. Devido às partes rugosas, todavia, pode-se inferir que tanto a relação superfície-volume do material quanto o atrito com substâncias que se desloquem no contato com a superfície sejam maiores que no caso do bagaço original. Logo, o uso do produto do processo Klason como adsorvente parece mais eficaz. 


\subsubsection{3}

\section{Resíduo de Produção de Celulose (RPC)}

A imagem a seguir (figura 33) foi feita com aumento $\times 120$.

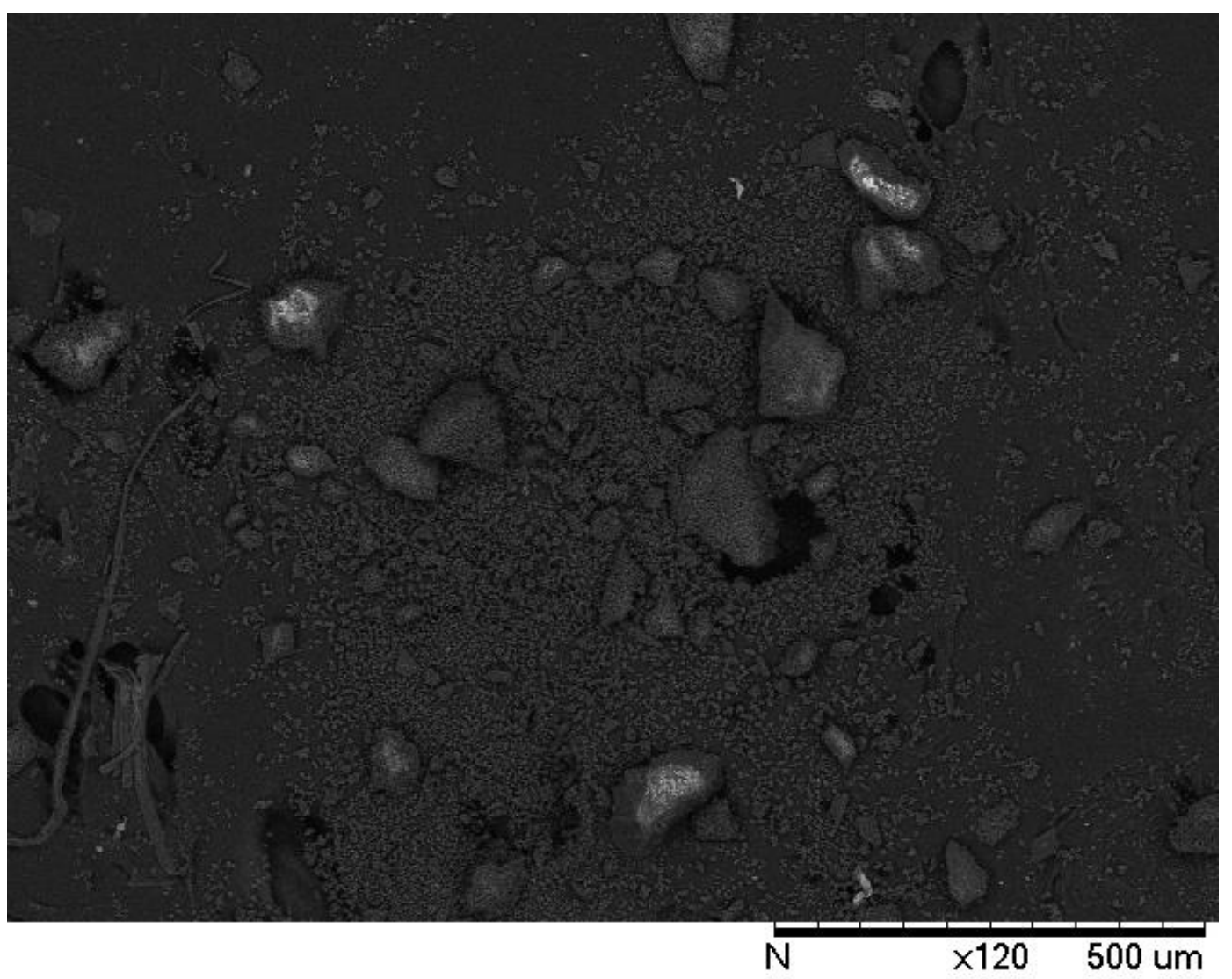

Figura 33 - Resíduo de produção de celulose ampliado x120

Nela, podem-se ver alguns objetos coesos maiores, mas também diversos grãos menores espalhados sobre a placa. Isso sugere que os maiores blocos sejam aglomerados dos menores, devendo-se fazer uma maior ampliação para obter melhores conclusões.

A figura 34 exibe uma ampliação $\times 10000$ da anterior, buscando-se focar nos menores grãos. 


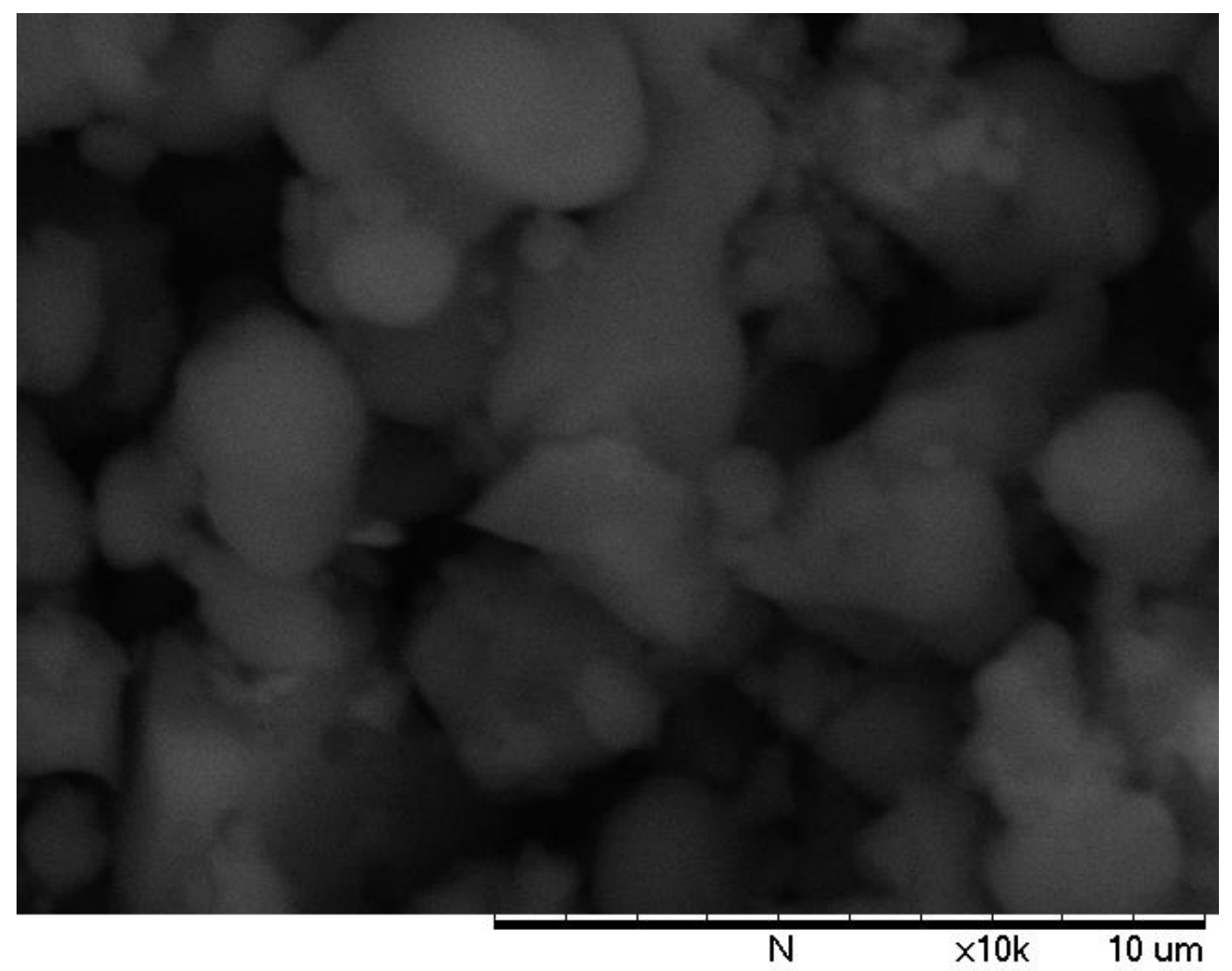

Figura 34 - Resíduo de produção de celulose ampliado x10000

Observando as feições dos grãos, tem-se que eles estão mais cominuídos que os vistos nas outras amostras. Além disso, a superfície não tem fibras em uma direção bem definida e exibe alguma rugosidade. 


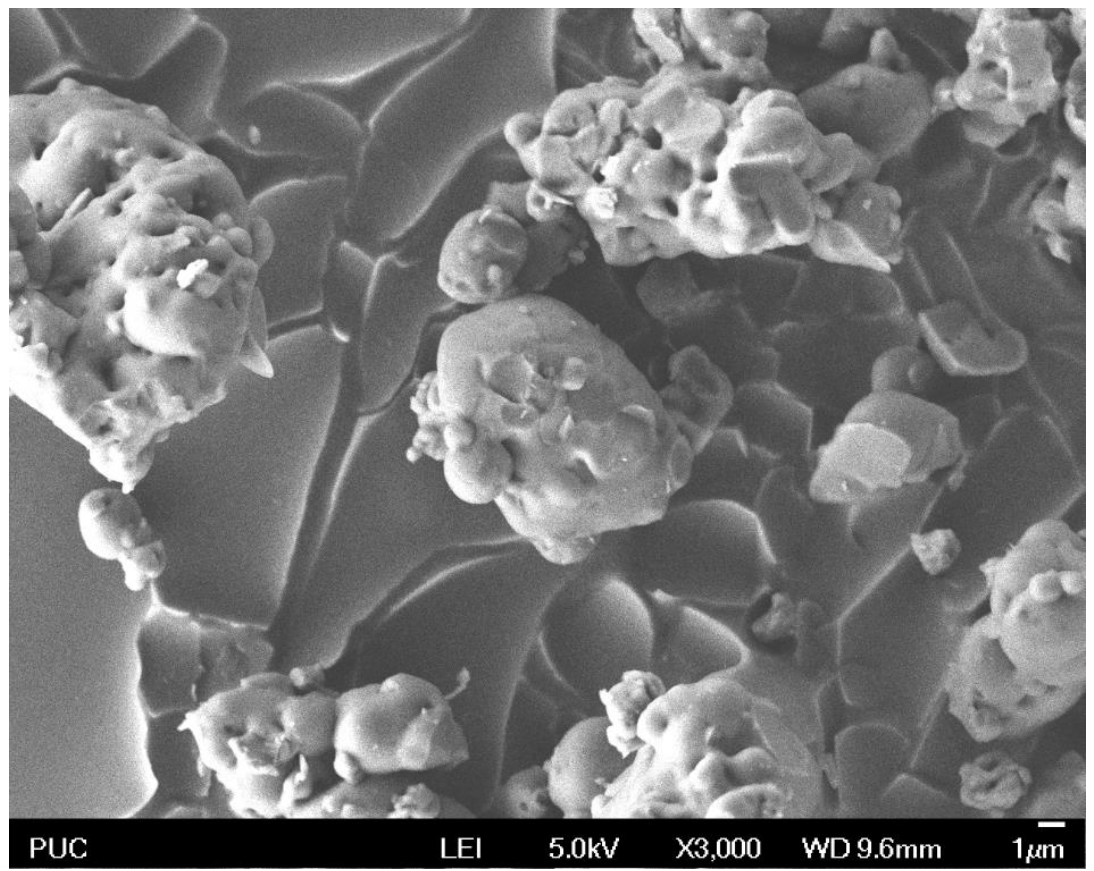

Figura 35 - Resíduo de produção de celulose ampliado x3000

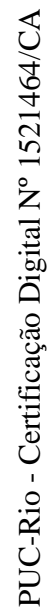

Tal imagem, obtida em outro equipamento, com tecnologia MEV-FEG, exibe o resíduo com maior nitidez, e está de acordo com os comentários feitos a partir das outras imagens.

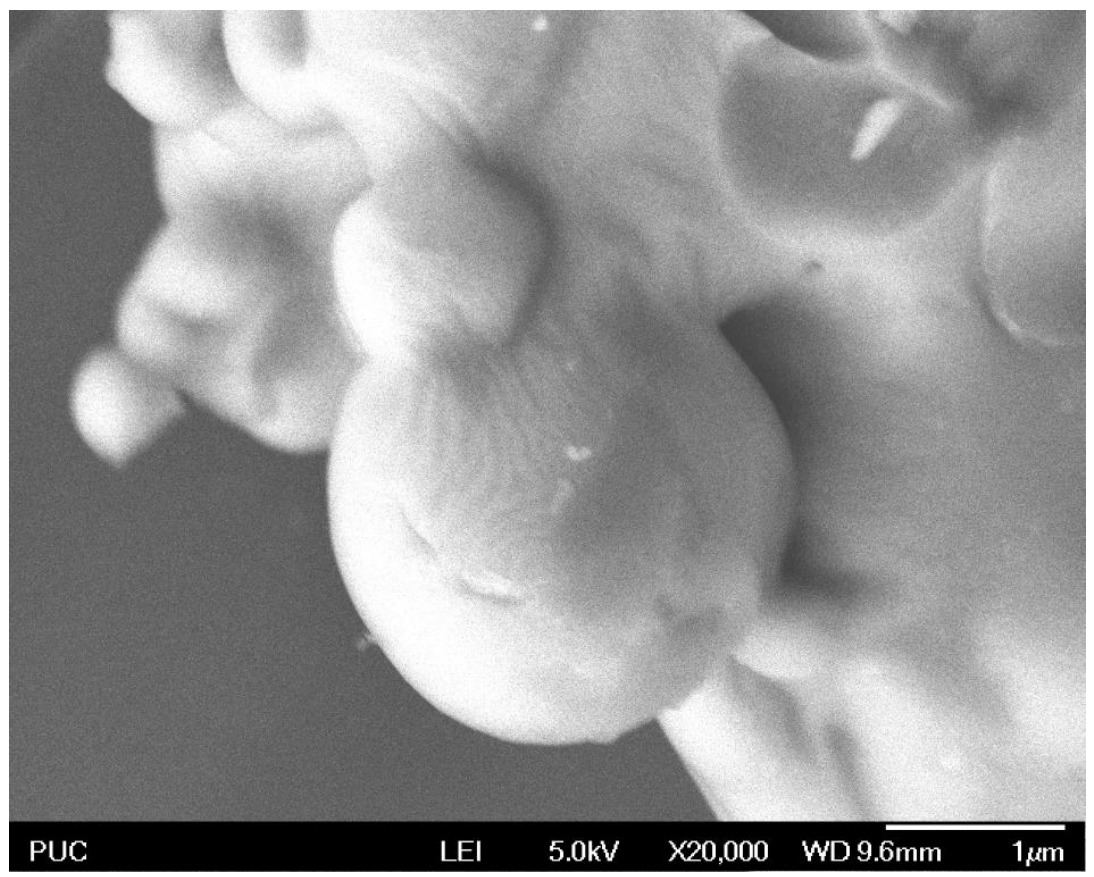

Figura 36 - Resíduo de produção de celulose ampliado ×20000 
Nela, vê-se uma ampliação da figura 35, de modo a se confirmar o que foi dito anteriormente.

Diante dessas imagens, conclui-se que tal resíduo tem grãos menores que os de outras amostras, sem uma direção definida de fibras e com uma rugosidade perceptível. A fina granulometria e a alta rugosidade sugerem grandes relação superfície-volume e atrito no contato com o meio externo, o que indica tendência de bom funcionamento como adsorvente.

\subsubsection{4}

Resíduo de Produção de Celulose Funcionalizado por Ácido Nítrico (RPCAN)

A figura 37 teve ampliação x120.

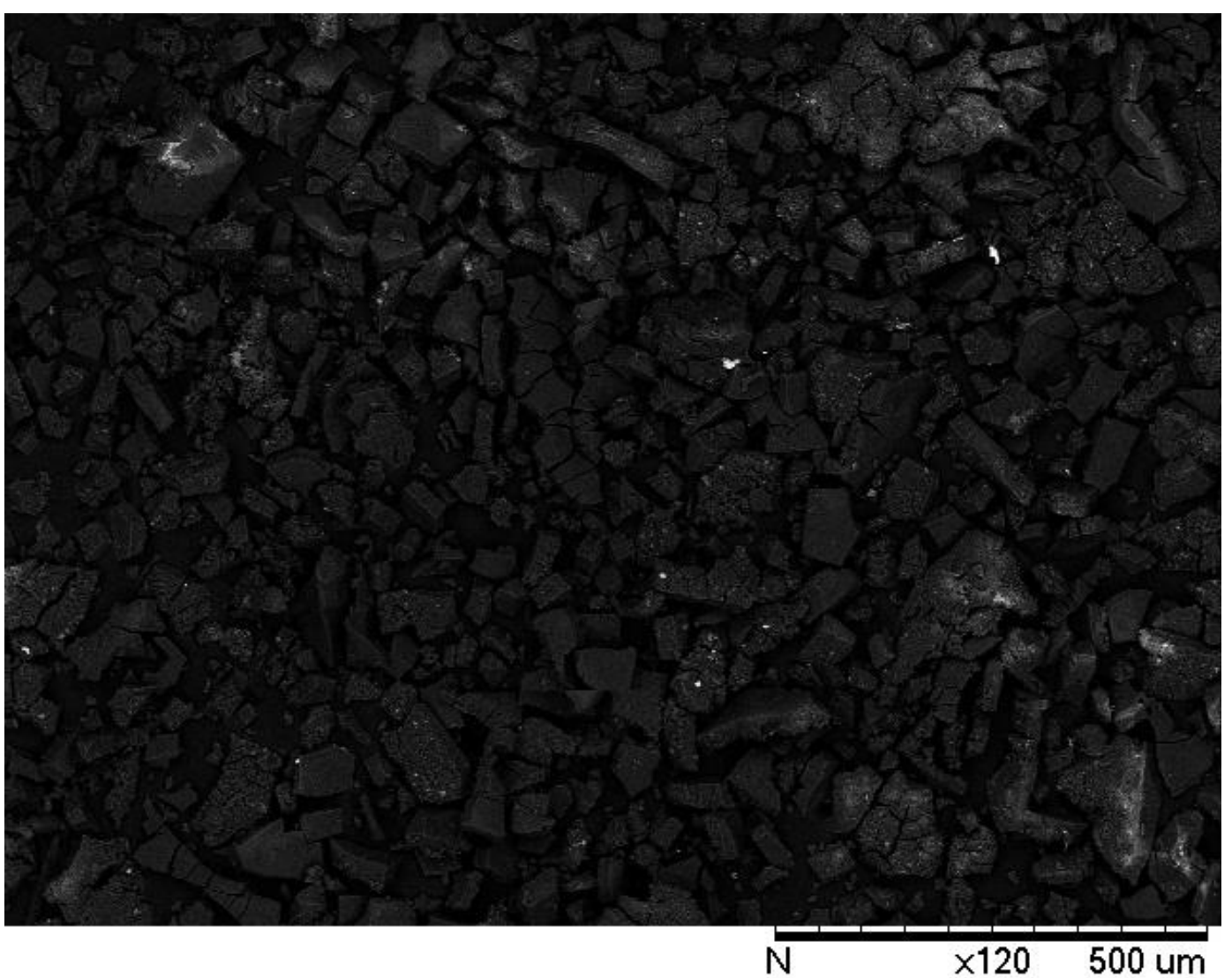


Figura 37 - Resíduo de produção de celulose funcionalizado por ácido nítrico e ampliado $\times 120$

Nela tem-se uma noção geral dos grãos. Eles parecem ter ganho uma maior coesão durante o processo de funcionalização, pois aparentam ter se afastado depois por meio de rachaduras.

A figura 38 expõe mais uma região, com aumento x1000.

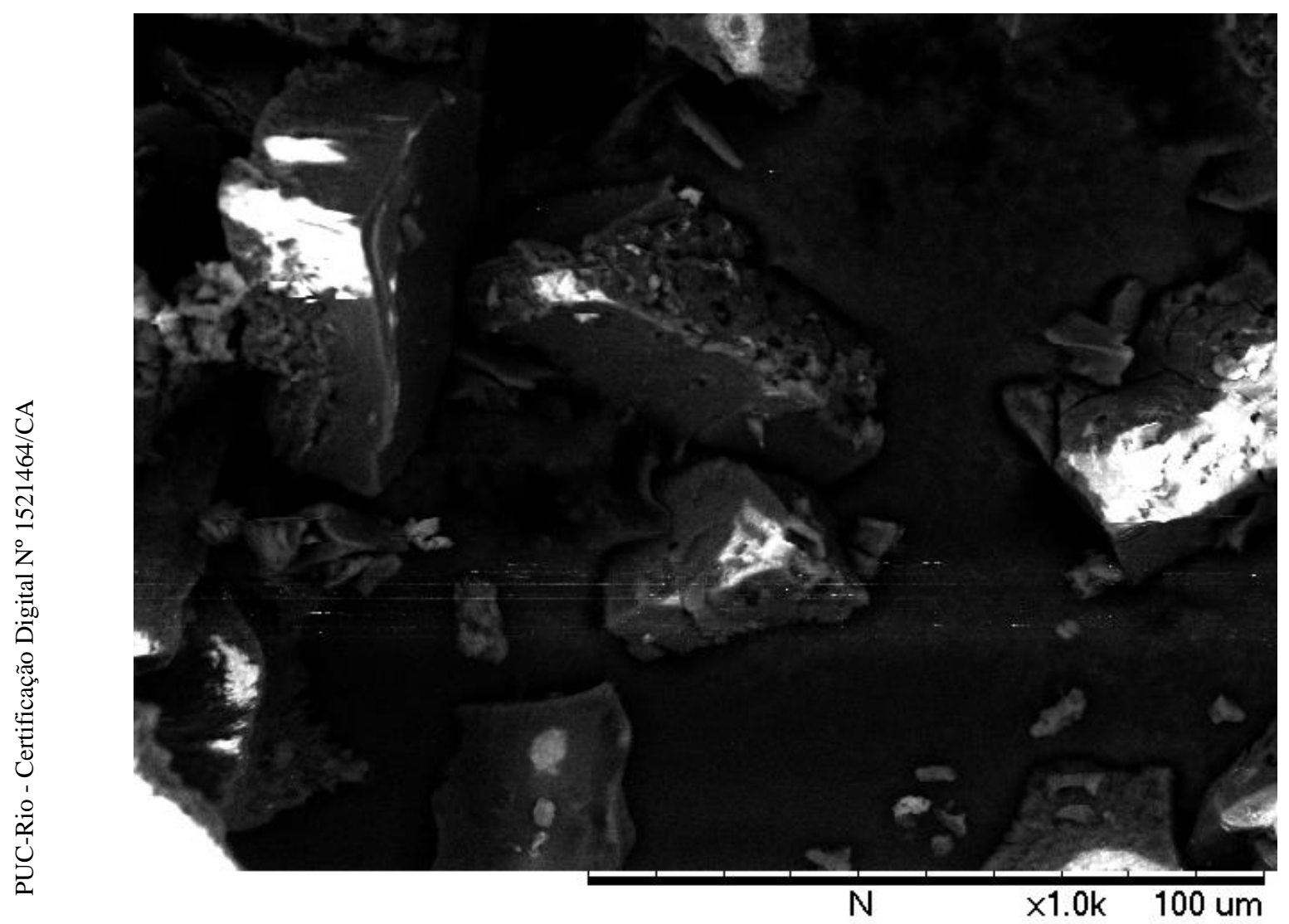

Figura 38 - Resíduo de produção de celulose funcionalizado por ácido nítrico e ampliado x1000

Nela, notam-se alta rugosidade da superfície e ausência de uma direção predominante de fibras. Além disso, percebe-se que o tratamento com $\mathrm{HNO}_{3}$ pode ter conferido uma maior porosidade ao material, observando-se o grão situado no centro da imagem, levemente acima.

A figura 39, apesar de não muito nítida, exibe um grão ampliado x10000. 


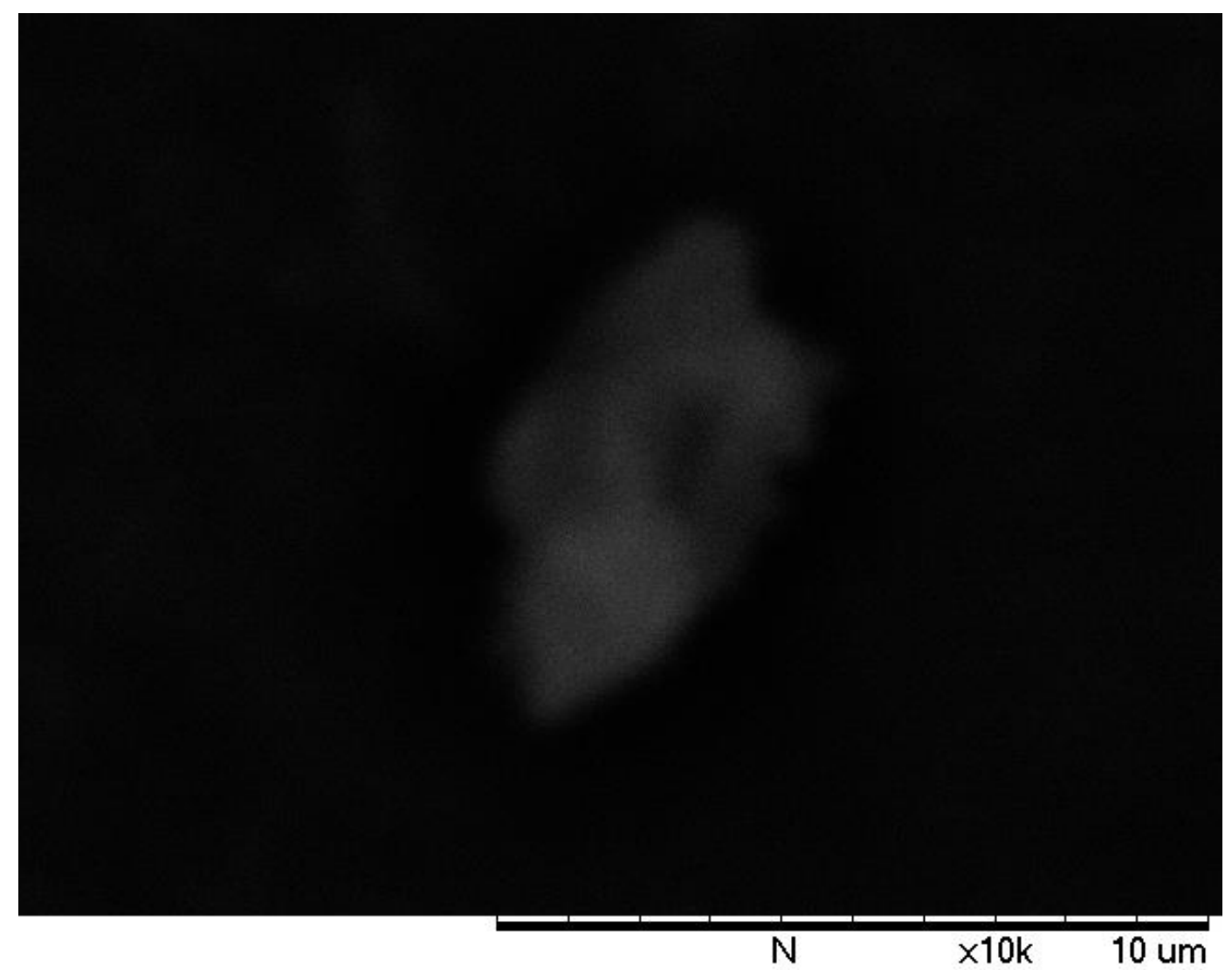

Figura 39 - Resíduo de produção de celulose funcionalizado por ácido nítrico e ampliado $\times 10000$

Nele, aparenta haver rugosidade e porosidade consideráveis.

Assim, nota-se que os grãos têm grande rugosidade, maior porosidade que no material antes da funcionalização, ausência de direção preferencial de fibras e, aparentemente, uma maior coesão entre si. A rugosidade e a porosidade sugerem grande relação entre a superfície e o volume, que resulta em propriedades de bom adsorvente, mas a coesão que parece ter surgido pode dificultar o contato do material com o exterior, visto que a superfície livre se tornou menor e a força de atração entre partículas do próprio material pode ser muito maior do que a de atração com elementos externos, como água e sais. 


\subsubsection{5}

\section{Resíduo de Produção de Celulose Funcionalizado por Ácido Fosfórico (RPCAF)}

A figura 40 teve ampliação x120.

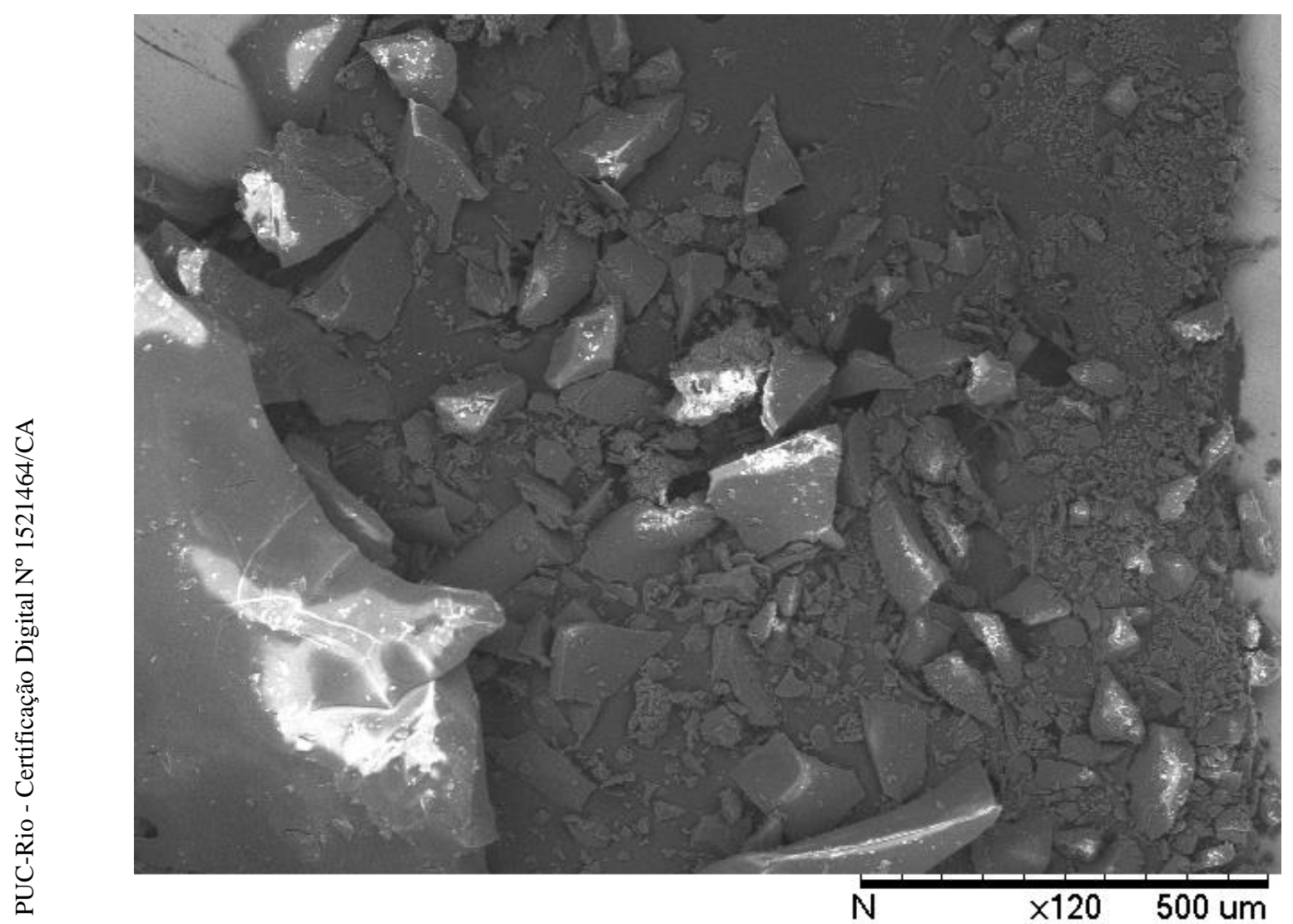

Figura 40 - Resíduo de produção de celulose funcionalizado por ácido fosfórico e ampliado $\times 120$

Ela exibe um panorama geral do material, permitindo, ainda, notar que não há muita rugosidade nem direção preferencial das fibras.

Selecionou-se um grão e se obteve a figura 41, com aproximação x3000, e a figura 42 , com $\times 30000$. 


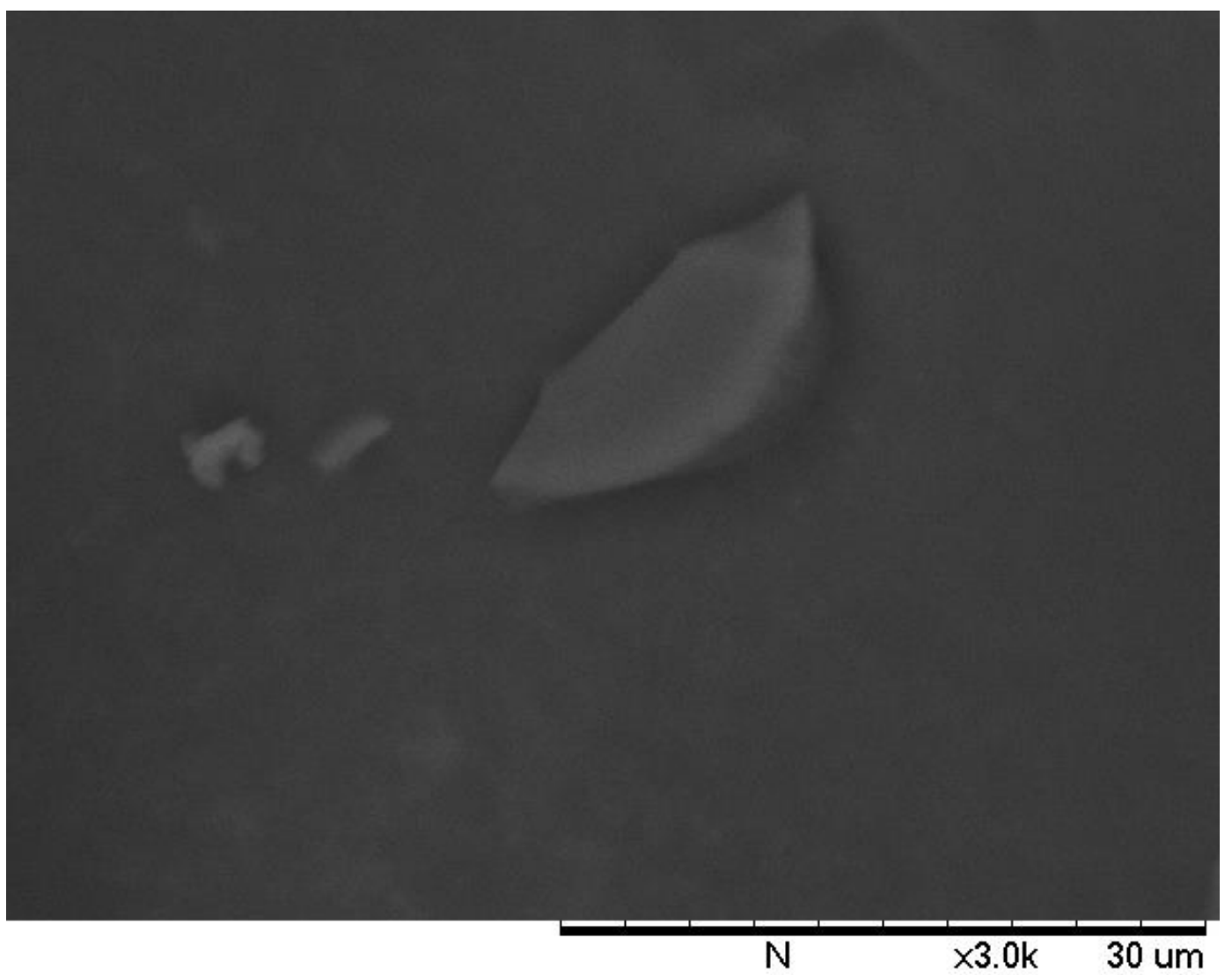

Figura 41 - Resíduo de produção de celulose funcionalizado por ácido fosfórico e ampliado $\times 3000$ 


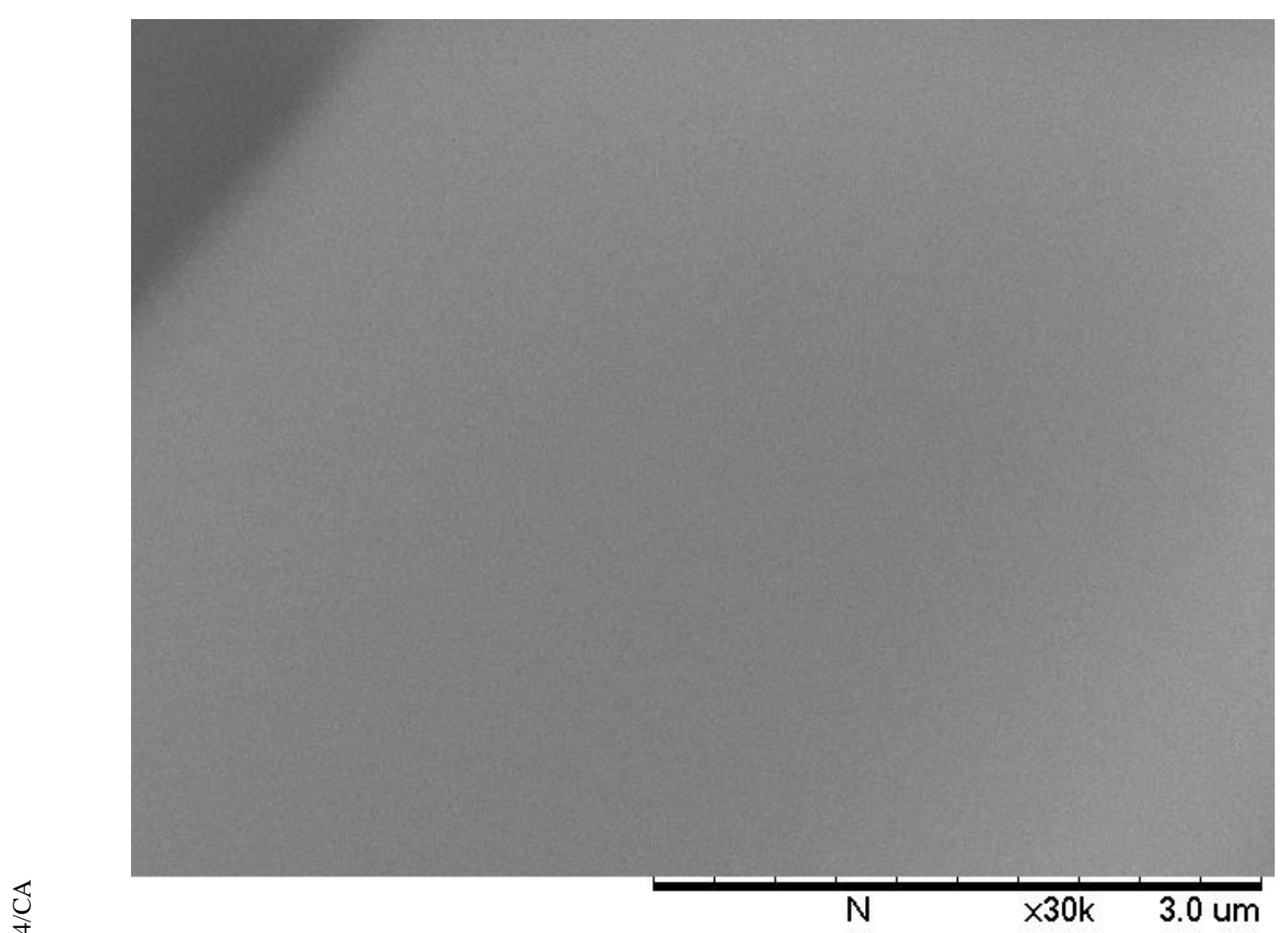

Figura 42 - Resíduo de produção de celulose funcionalizado por ácido fosfórico e ampliado $\times 30000$

Em tais imagens, o grão aparenta ter permanecido liso.

A figura 43 traz outro grão com ampliação x30000. 


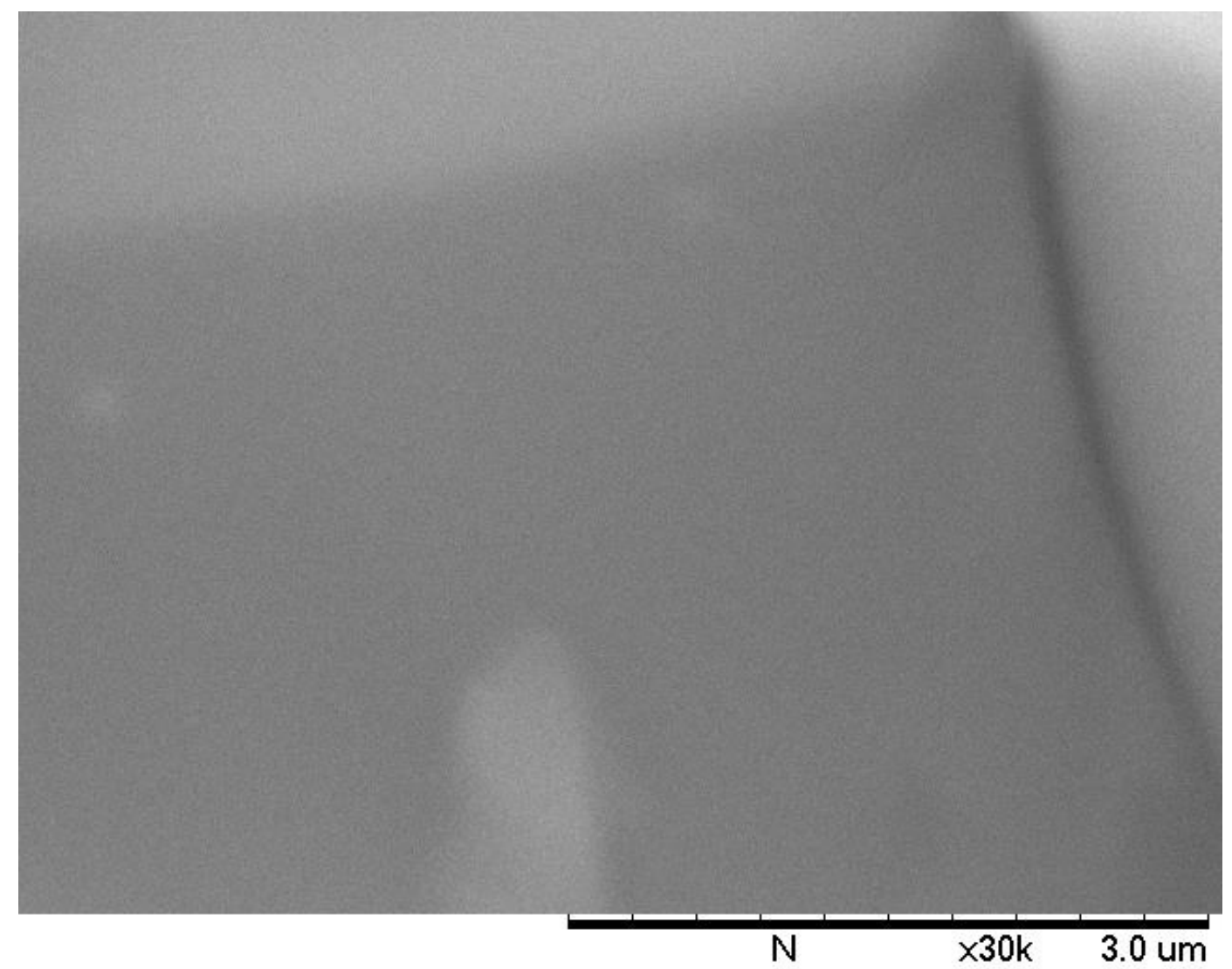

Figura 43 - Resíduo de produção de celulose funcionalizado por ácido fosfórico e ampliado x30000 em $2^{2}$ região

Ela ressalta quão lisa ficou a superfície do material.

Tais figuras revelaram um material com pouca rugosidade, baixa porosidade e sem direção preferencial das fibras. Essas duas primeiras características sugerem que não seja um bom adsorvente, pois não houve incremento da superfície de contato.

\subsubsection{6}

Resíduo de Produção de Celulose Funcionalizado por Ácido Acético (RPCAA)

A figura 44 foi feita com ampliação x120. 


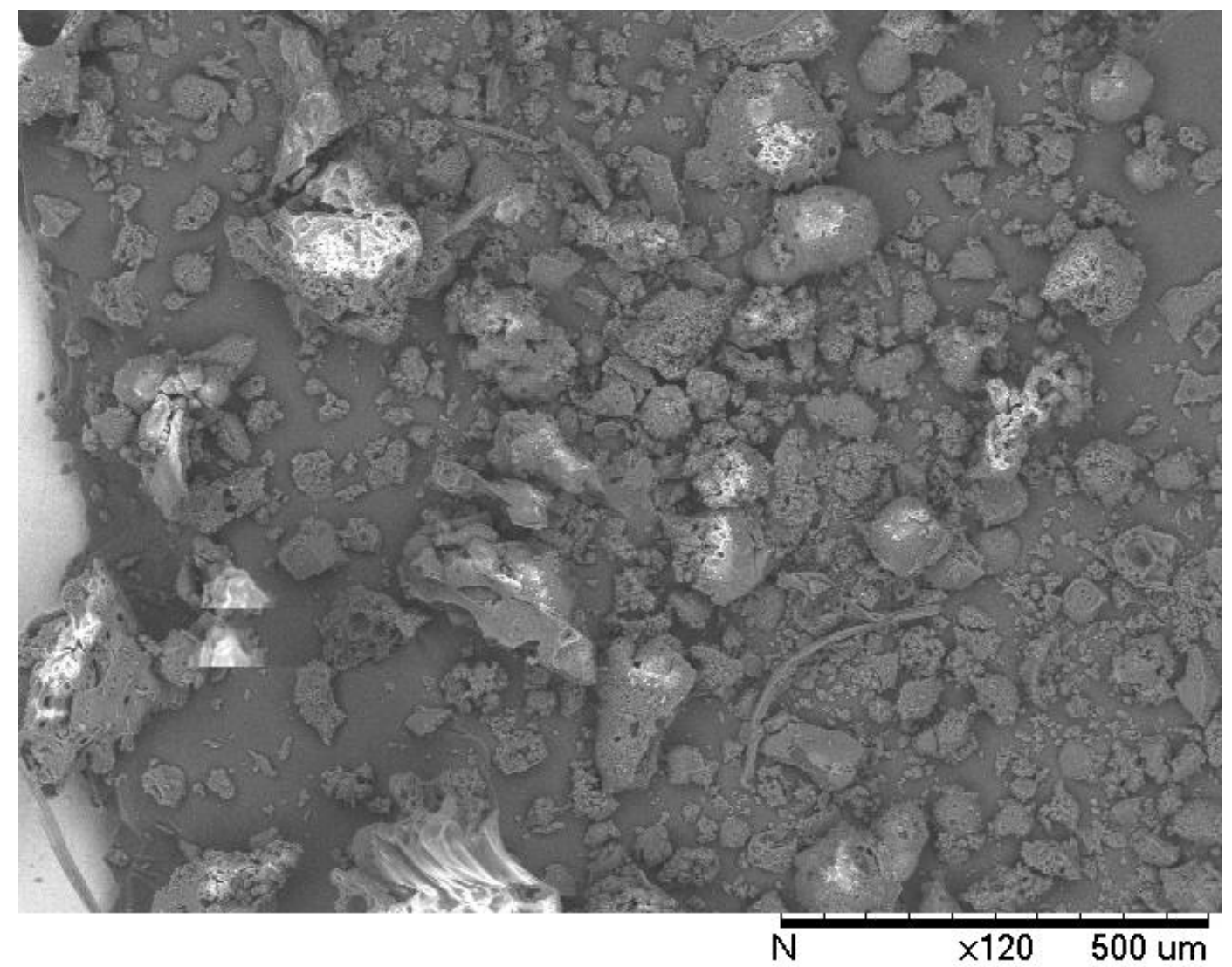

Figura 44 - Resíduo de produção de celulose funcionalizado por ácido acético e ampliado $\times 120$

Nela, além da visão geral do material, pode-se observar que o tratamento com ácido acético fez surgirem poros. Para um maior detalhamento, fez-se a ampliação x10000, originando-se a figura 45. 


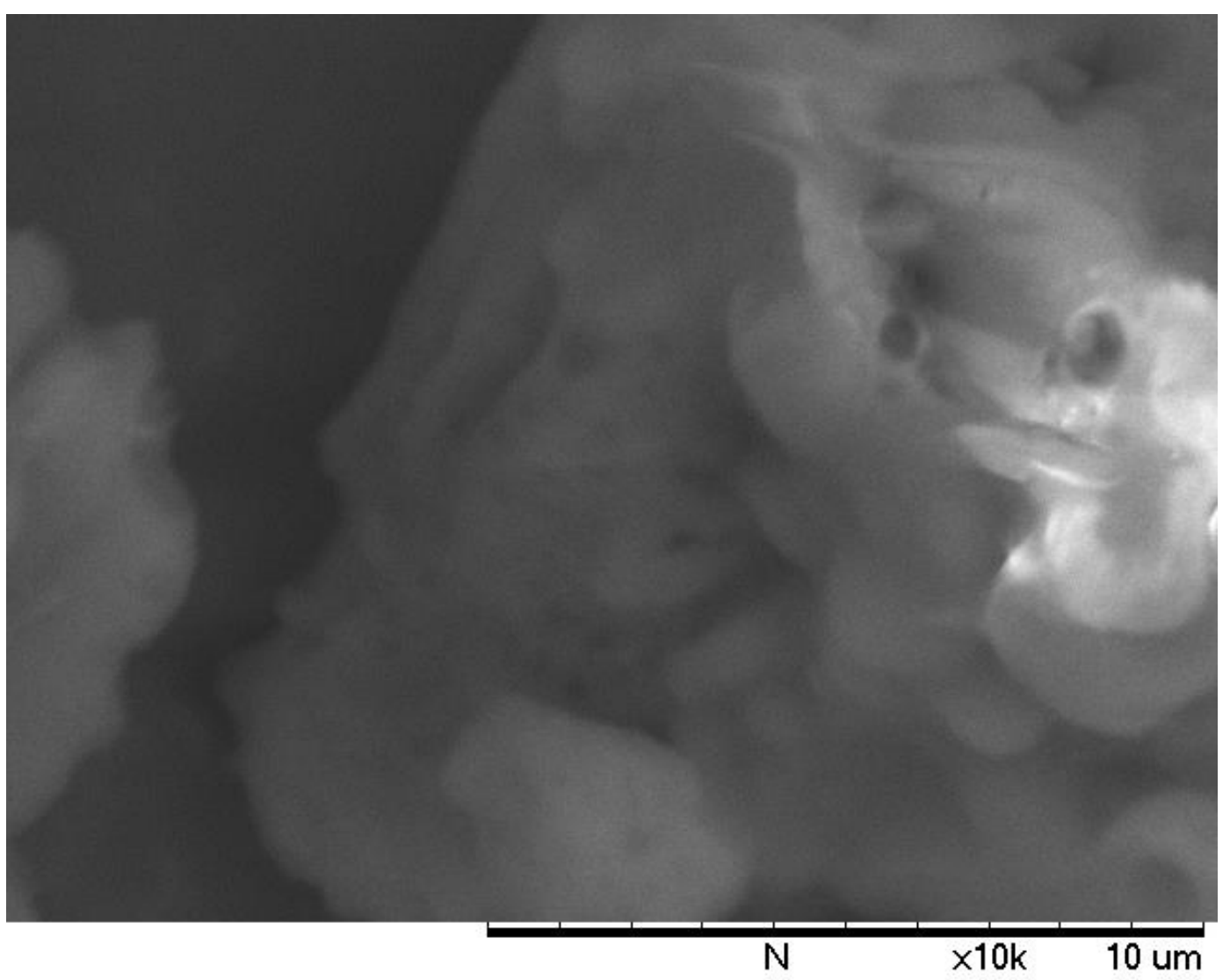

Figura 45 - Resíduo de produção de celulose funcionalizado por ácido acético e ampliado x10000

Nela, notam-se a alta rugosidade, a ausência de direção preferencial de fibras e a grande porosidade, com o surgimento de diversos buracos de aspecto redondo sobre a superfície.

Escolheu-se ainda um grão de outra região, montando-se a figura 46 , de ampliação x1000. 


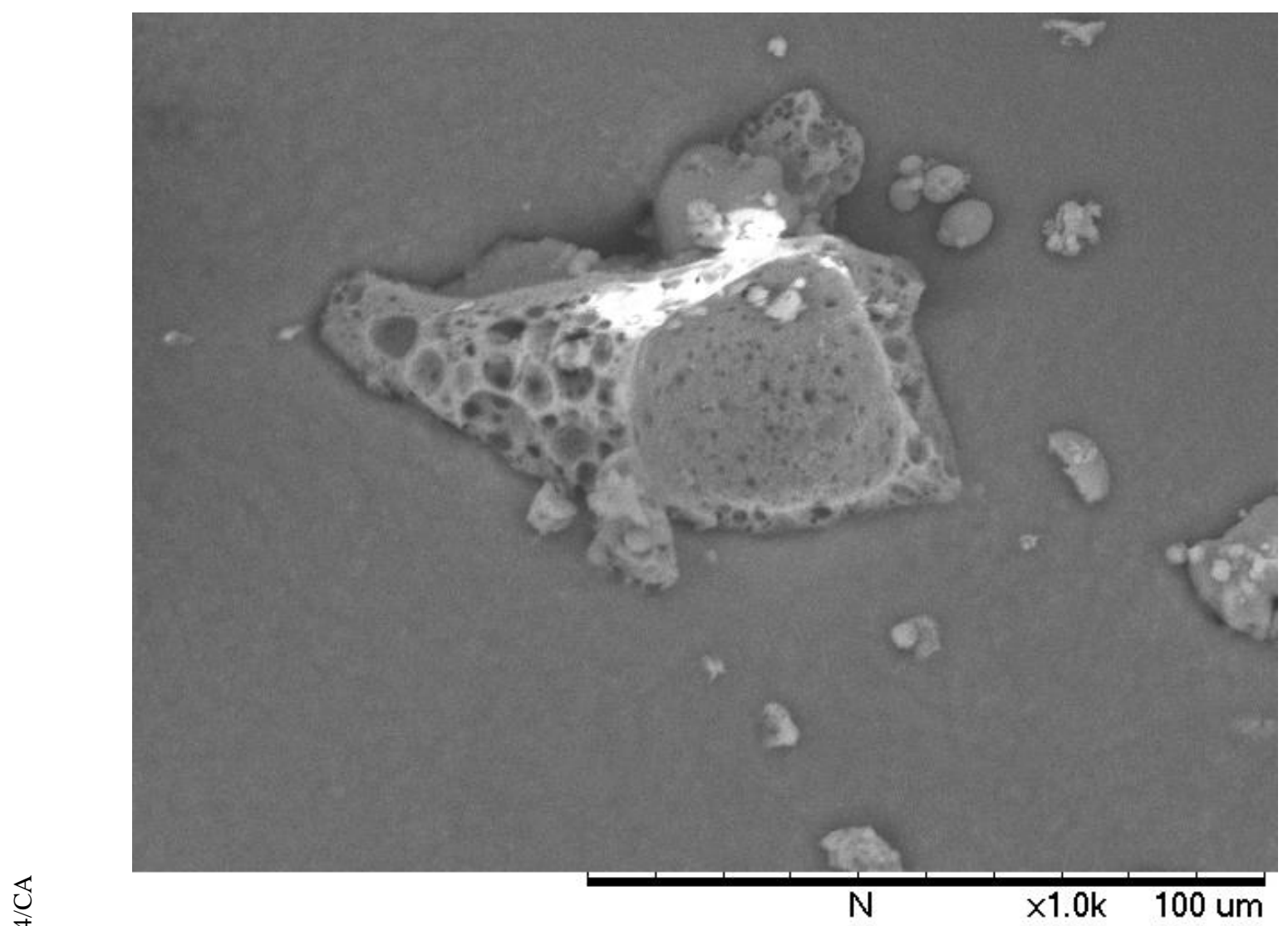

Figura 46 - Resíduo de produção de celulose funcionalizado por ácido acético e ampliado $\times 1000$

Nota-se a grande porosidade do material. Devido ao formato arredondado dos poros e à ausência dos mesmos nas outras amostras, infere-se que seu surgimento decorra da funcionalização com ácido acético.

A partir de um grão de outra região, obteve-se também a figura 47 , de aumento $\times 1000$. 


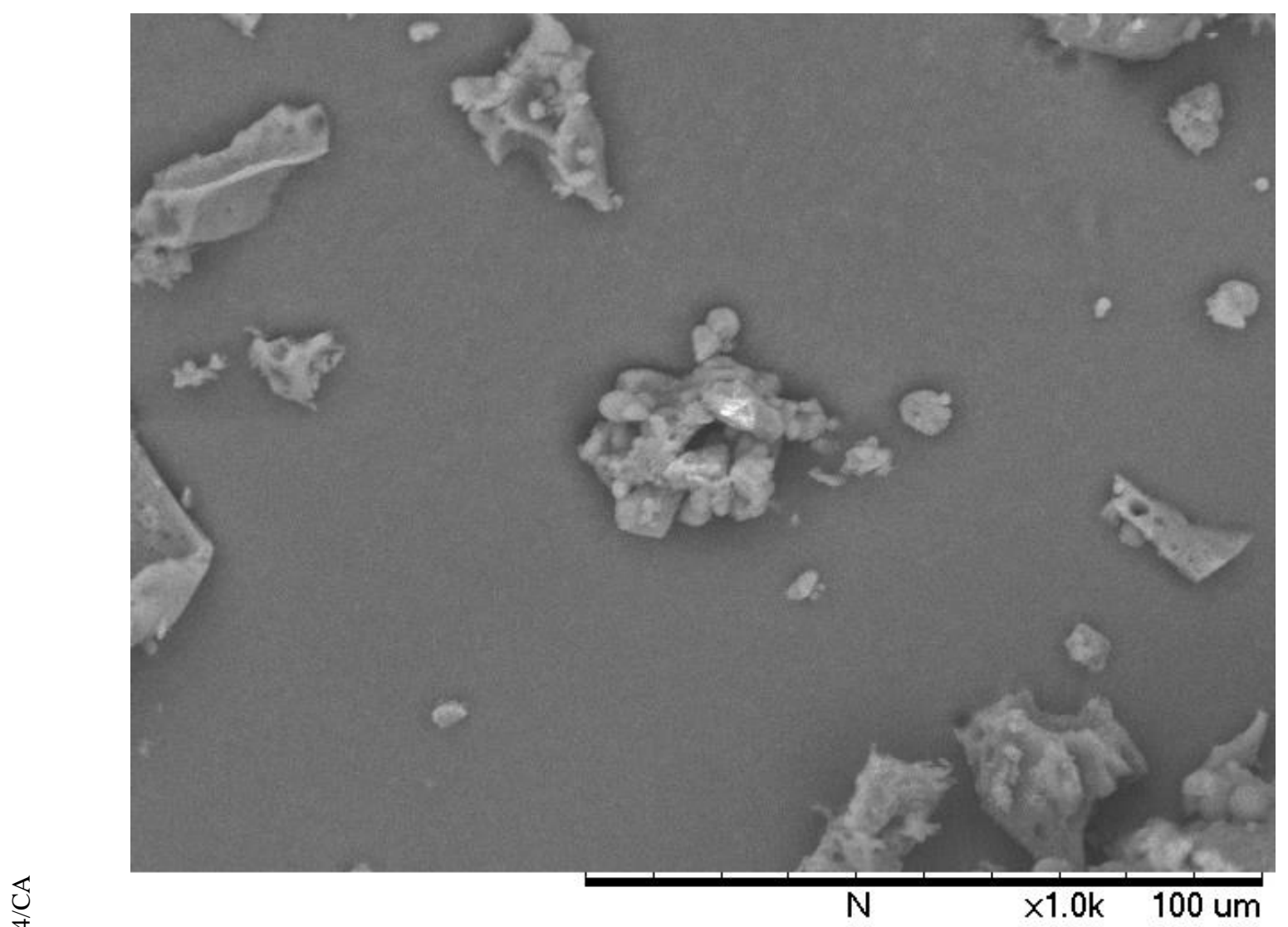

Figura 47 - Resíduo de produção de celulose funcionalizado por ácido acético e ampliado x1000 em $2^{2}$ região

Nele, embora a porosidade não seja tão evidente, pode-se notar grande rugosidade. 


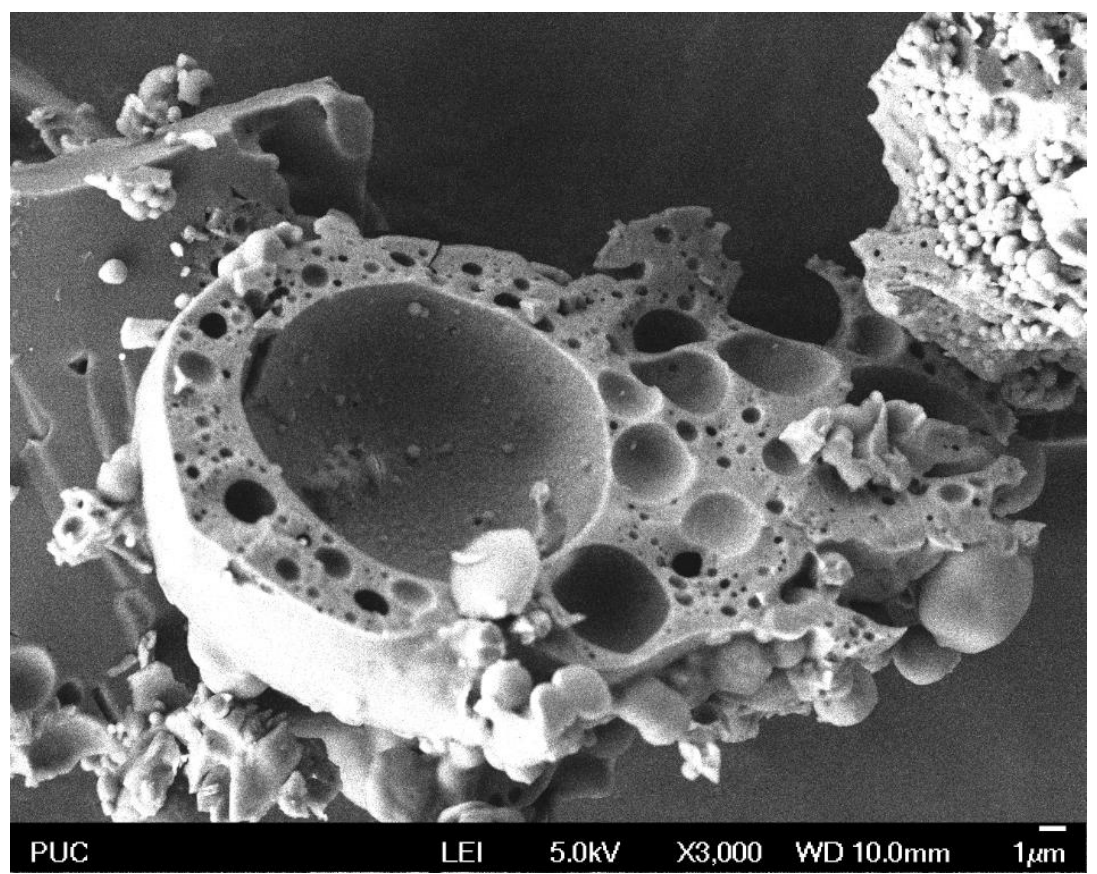

Figura 48 - Resíduo de produção de celulose funcionalizado por ácido acético e ampliado $\times 3000$

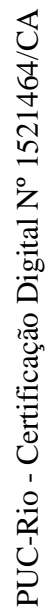

Tal imagem, obtida em outro equipamento, com tecnologia MEV-FEG, corrobora o surgimento de poros.

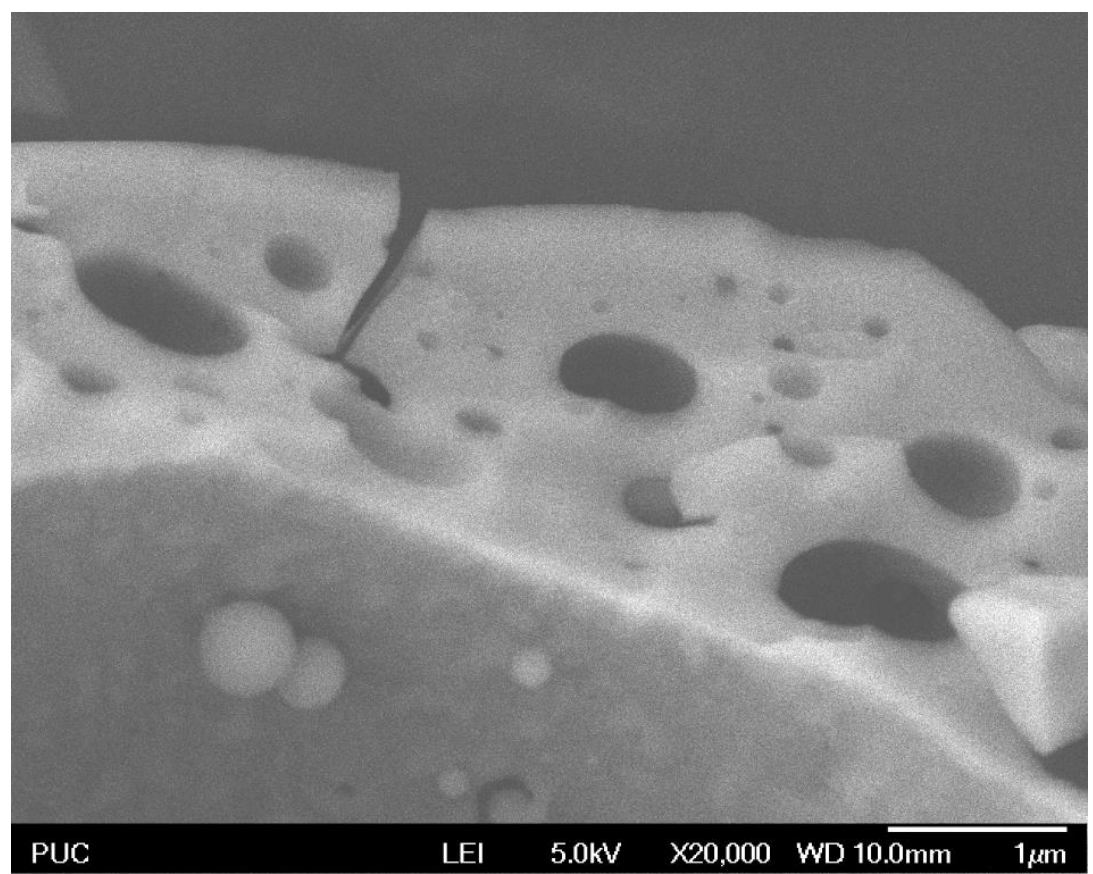


Figura 49 - Resíduo de produção de celulose funcionalizado por ácido acético e ampliado $\mathrm{x} 20000$

Essa figura mostra em maior ampliação os poros vistos na figura 48, confirmando os comentários já tecidos acerca da amostra.

Assim, percebem-se a ausência de direção preferencial das fibras, bem como as grandes rugosidade e porosidade na amostra. Estas duas últimas características sugerem que o material tenha uma elevada relação superfícievolume, o que favorece seu uso como adsorvente. A rugosidade, além disso, tende a elevar o atrito com materiais externos, o que também contribui para o mecanismo de adsorção.

\section{4 .2}

\section{Espectroscopia de Raio X por Energia Dispersiva (EDS)}

Nas análises de EDS foi possível identificar alguns dos elementos químicos que compõem os materiais, o que possibilita uma melhor compreensão de sua natureza.

Os elementos detectados com maior destaque foram o carbono, o oxigênio e o enxofre. Os 2 primeiros são naturalmente presentes na estrutura molecular da biomassa. Porém, o oxigênio serve também como parâmetro para inferir a quão oxidada ela foi, compreendendo-se melhor a eficácia dos processos de funcionalização. O enxofre, diferentemente, não é natural da composição da biomassa, e foi detectado em resíduos que não foram tratados com compostos contendo enxofre. Assim, infere-se que a produção do material a partir do licor negro tenha envolvido o uso de compostos com enxofre, como o ácido sulfúrico, e haja uma presença residual dessa substância nas amostras.

Portanto, o EDS faz mais sentido para os materiais que passaram por funcionalização, pois a revelação do teor de oxigênio auxilia na interpretação da eficácia. A técnica foi usada apenas com as amostras de RPC, RPCAN, RPCAF e RPCAA. 
Para cada amostra obteve-se um gráfico, uma tabela e a imagem onde foi feita a medição. Como as 4 imagens são muito similares, por terem sido feitas em pastilhas em vez do pó original, exibe-se aqui apenas uma (figura 50), correspondente ao RPC não funcionalizado.

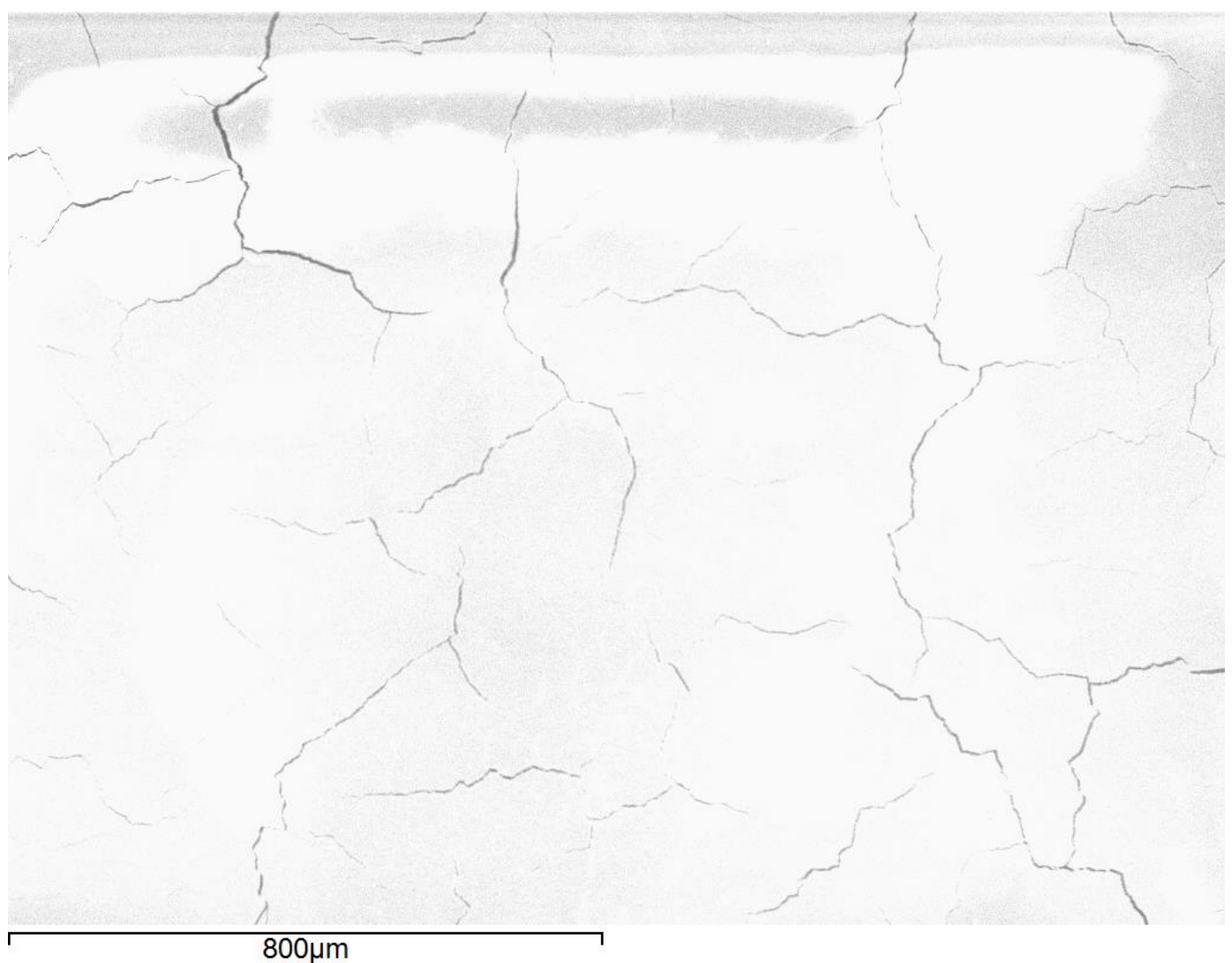

Figura 50 - Superfície da pastilha de resíduo de produção de celulose ampliada $\times 100$

\subsubsection{1}

\section{Resíduo de Produção de Celulose (RPC)}




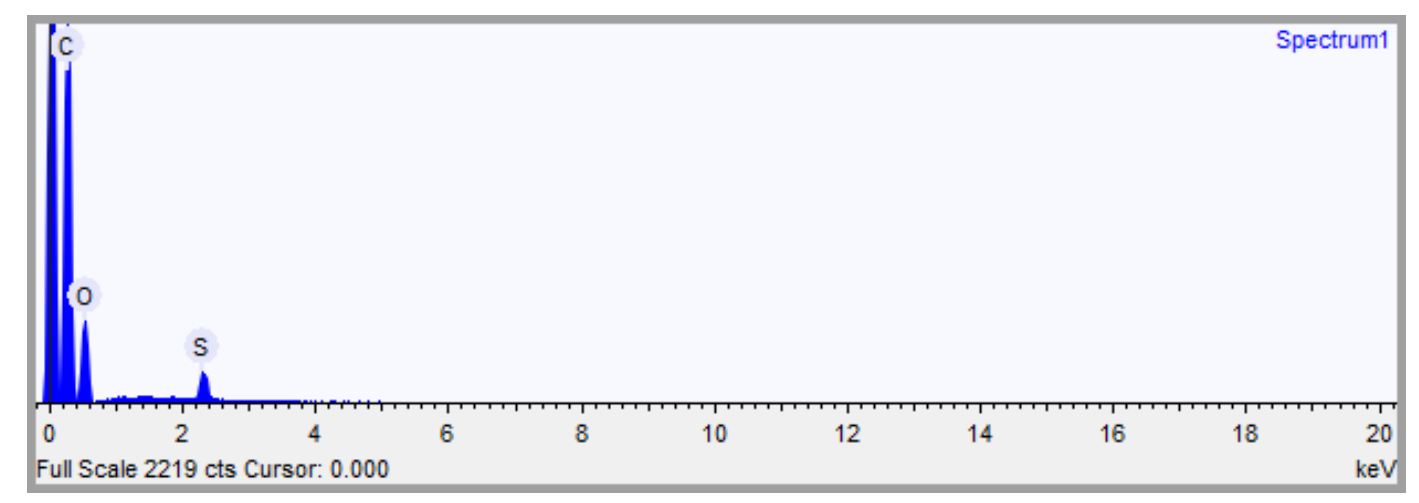

Gráfico 7 - Resultado de EDS do resíduo de produção de celulose

\begin{tabular}{llll}
\hline Elemento & Peso \% & Peso \% o & Atômica \% \\
\hline Carbono & 66.109 & 0.677 & 72.759 \\
Oxigênio & 32.052 & 0.683 & 26.483 \\
Enxofre & 1.840 & 0.094 & 0.758 \\
\hline
\end{tabular}

Tabela 6 - Resultado de EDS do resíduo de produção de celulose

Destaca-se a porcentagem atômica de carbono, cuja presença era esperada, visto que a amostra é de matéria orgânica. Nota-se também um teor de oxigênio, com presença também natural. A quantidade de enxofre não é natural da matéria lignocelulósica, sendo sua presença provavelmente devida a reações da matéria-prima com outros produtos que contêm enxofre, como o ácido sulfúrico, em processos que resultaram no resíduo analisado.

\subsubsection{2}

Resíduo de Produção de Celulose Funcionalizado por Ácido Nítrico (RPCAN) 


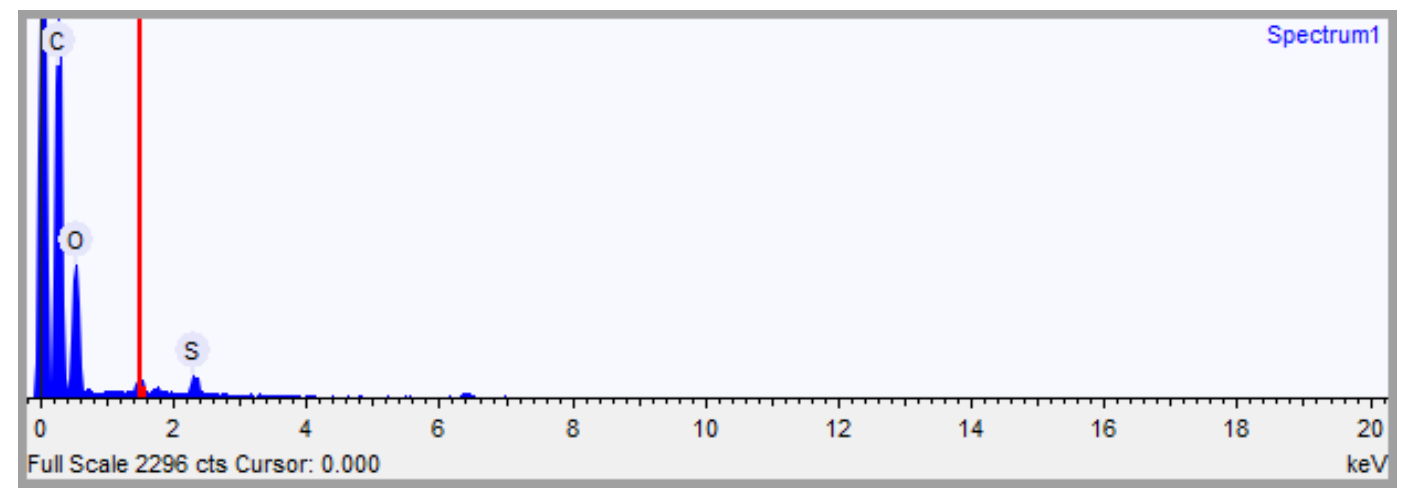

Gráfico 8 - Resultado de EDS do resíduo de produção de celulose funcionalizado por ácido nítrico

\begin{tabular}{llll}
\hline Elemento & Peso \% & Peso \% o & Atômica \% \\
\hline Carbono & 58.672 & 0.625 & 65.706 \\
Oxigênio & 40.256 & 0.629 & 33.844 \\
Enxofre & 1.072 & 0.073 & 0.450 \\
\hline
\end{tabular}

Tabela 7 - Resultado de EDS do resíduo de produção de celulose funcionalizado por ácido nítrico

Apareceram carbono, oxigênio e enxofre, atendendo ao esperado. O maior teor de oxigênio em relação ao RPC original sugere que o tratamento com $\mathrm{HNO}_{3}$ realmente resultou em oxidação.

\subsubsection{3}

Resíduo de Produção de Celulose Funcionalizado por Ácido Fosfórico (RPCAF) 


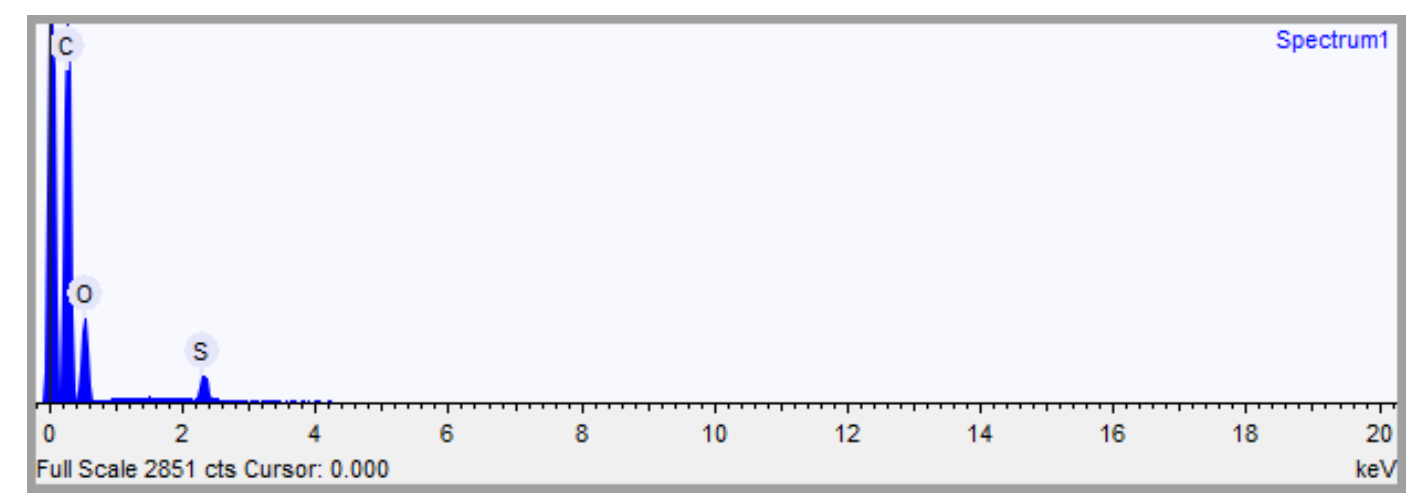

Gráfico 9 - Resultado de EDS do resíduo de produção de celulose funcionalizado por ácido fosfórico

\begin{tabular}{llll}
\hline Elemento & Peso \% & Peso \% o & Atômica \% \\
\hline Carbono & 65.741 & 0.598 & 72.339 \\
Oxigênio & 32.715 & 0.603 & 27.025 \\
Enxofre & 1.544 & 0.076 & 0.636 \\
\hline
\end{tabular}

Tabela 8 - Resultado de EDS do resíduo de produção de celulose funcionalizado por ácido fosfórico

Apenas carbono, oxigênio e enxofre. O menor aumento na fração de oxigênio sugere que a funcionalização não foi tão intensa quanto a do ácido nítrico.

\subsubsection{4}

Resíduo de Produção de Celulose Funcionalizado por Ácido Acético (RPCAA) 


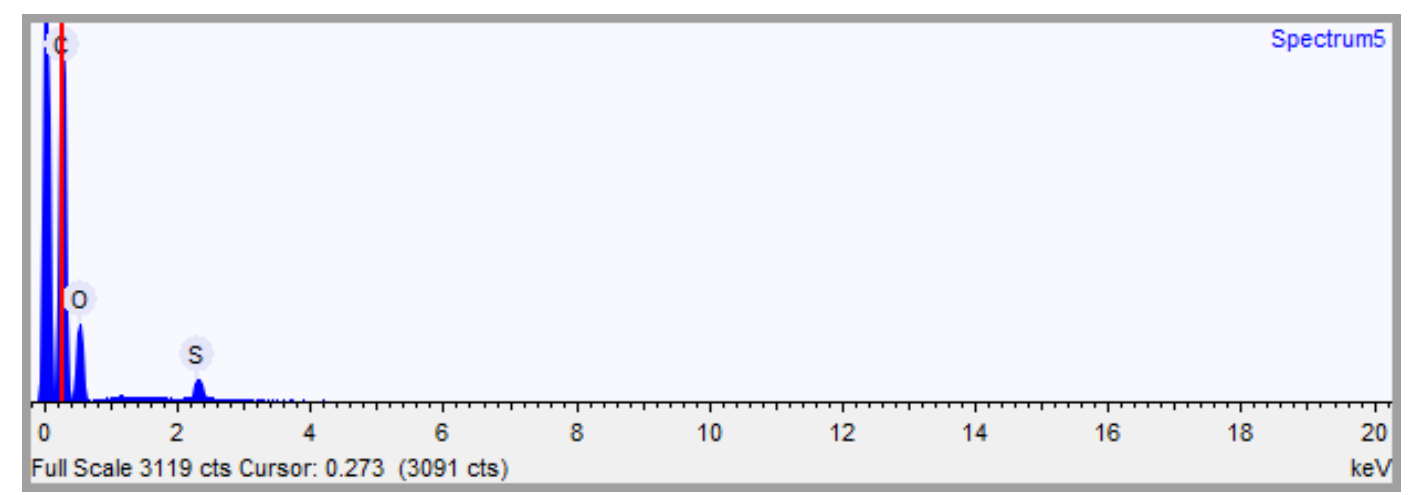

Gráfico 10 - Resultado de EDS do resíduo de produção de celulose funcionalizado por ácido acético

\begin{tabular}{llll}
\hline Elemento & Peso \% & Peso \% o & Atômica \% \\
\hline Carbono & 66.101 & 0.586 & 72.626 \\
Oxigênio & 32.479 & 0.591 & 26.790 \\
Enxofre & 1.420 & 0.074 & 0.584 \\
\hline
\end{tabular}

Tabela 9 - Resultado de EDS do resíduo de produção de celulose funcionalizado por ácido acético

Também apenas carbono, oxigênio e enxofre. O teor de oxigênio ficou apenas um pouco maior, o que torna necessárias outras técnicas (como o FTIR) para se estimar a eficácia da funcionalização. O enxofre apresentou redução, provavelmente devida ao efeito de lavagem exercido pelo tratamento com ácido.

\section{5}

\section{Espectroscopia no infravermelho por transformada de Fourier (FTIR)}

A análise de Espectroscopia no infravermelho por transformada de Fourier (FTIR) forneceu um gráfico para cada amostra, no qual o eixo das abscissas corresponde ao comprimento de onda, $\mathrm{em} \mathrm{cm}^{-1}$; e o das ordenadas expressa a absorbância apresentada pelo material para cada comprimento de onda. $O$ software PerkinElmer Spectrum, instalado no próprio computador associado ao 
detector do FTIR, forneceu 3 dados: as tabelas com os dados para esses gráficos, as informações de picos de absorbância e os próprios gráficos. Porém, para maior clareza, os gráficos foram refeitos no software Origin, a partir das referidas tabelas.

Comparando os picos de absorbância à literatura, foi possível apontar os prováveis grupos funcionais de cada material.

\section{5 .1}

\section{Resíduo de Produção de Celulose (RPC)}

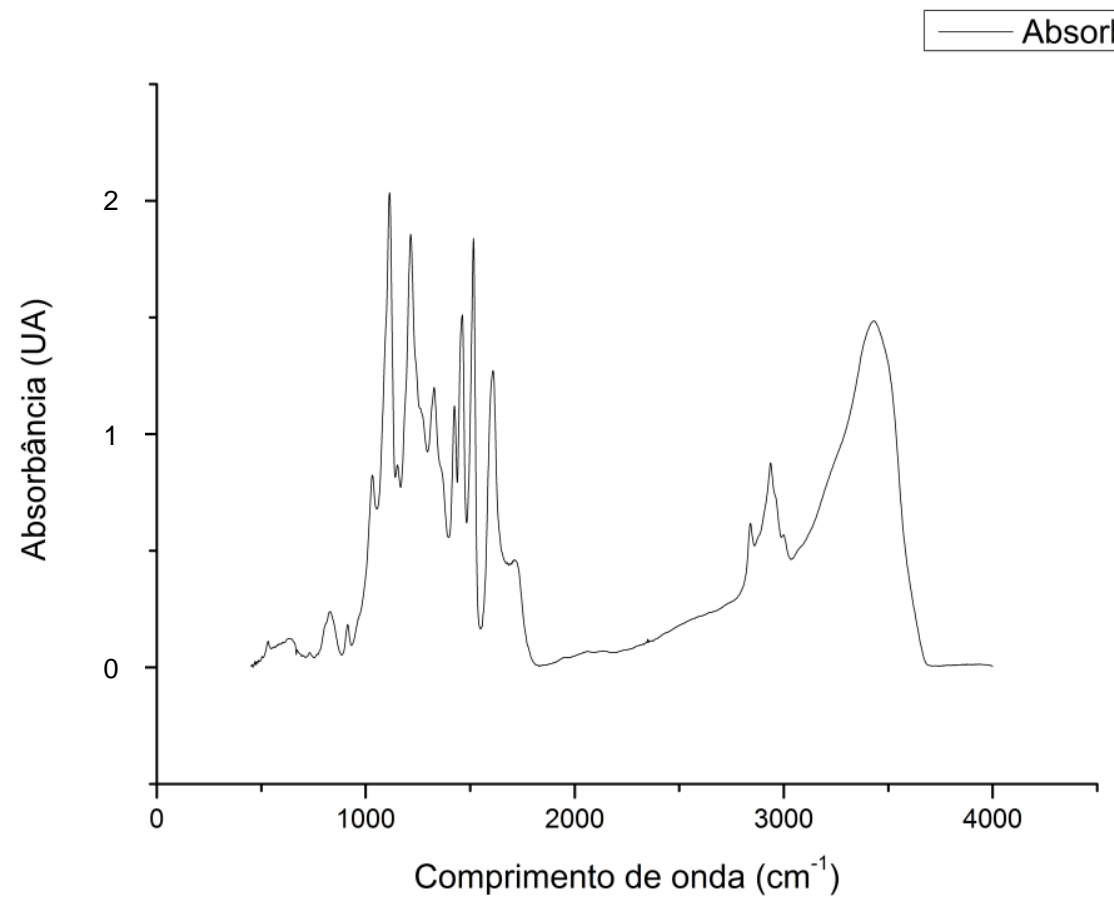

Gráfico 11 - Absorbância x Comprimento de Onda da análise FTIR do resíduo de produção de celulose

Lista de picos:

\begin{tabular}{|l|}
\hline 3431 \\
\hline 2998 \\
\hline 2937 \\
\hline
\end{tabular}




\begin{tabular}{|l|}
\hline 2840 \\
\hline 1712 \\
\hline 1610 \\
\hline 1516 \\
\hline 1462 \\
\hline 1425 \\
\hline 1327 \\
\hline 1215 \\
\hline 1152 \\
\hline 1114 \\
\hline 1032 \\
\hline 914 \\
\hline 829 \\
\hline 732 \\
\hline 631 \\
\hline 530 \\
\hline
\end{tabular}

$\mathrm{Na}$ interpretação dos resultados, um dos picos que chama a atenção é o de $3431 \mathrm{~cm}^{-1}$. De acordo com a literatura, tal faixa corresponde à hidroxila $(\mathrm{OH})$ alcoólica e fenólica. Isso indica que o material pode estar parcialmente oxidado, apesar de ainda não ter passado por tratamento com ácido. Logo, ele já pode ser visto como um candidato ao uso como adsorvente em solos. Contudo, mostra-se necessário interpretar ainda outros picos desse material e, naturalmente, comparar todos aos picos das demais amostras, quer foram tratadas por ácido, para conhecimento mais amplo dos materiais e inferência quantitativa do nível de oxidação.

Outro pico notável, apesar de com menor amplitude, é o de 2998. Ele pode ser associado a ligações $\mathrm{C}-\mathrm{H}$ aromáticas. Isso era esperado, visto que a lignina possui anéis de benzeno em sua composição. Todavia, isso não revela nenhuma característica de adsorvente, sendo apenas um dado a ser registrado e considerado coerente.

Os picos de 2937 e 2840 podem ser traduzidos como C-H alifático. Tal tipo de ligação também não surpreende, pois tanto a celulose e a hemicelulose possuem cadeias não-aromáticas e a própria lignina as tem, associadas aos anéis aromáticos. Então, tem-se aqui mais um dado coerente, apesar de não trazer informações sobre as propriedades de adsorvente. 
O de 1712 pode ser apontado como carboxila $(\mathrm{COOH})$ e carbonila $(\mathrm{C}=\mathrm{O})$ não conjugada. Esses grupos, novamente, podem ser indicativos da oxidação do material, tendendo a torná-lo um bom adsorvente.

O valor de 1610 pode ser aproximado para ligações do tipo $C=C$ aromática e $\mathrm{C}=\mathrm{O}$, repetindo os resultados revelados por outros picos já citados. O de 1516, igualmente, aponta $\mathrm{C}=\mathrm{C}$.

Os comprimentos de 1462 e 1425 são ditos como C-H em grupos metílicos, o que também é esperado na matéria orgânica observada.

Em 1327, têm-se ésteres e orto-arila. Assim, novamente, vê-se a oxidação indicativa de propriedades de adsorção.

O pico de 1215 associa-se a ligações C-O, assim como o 1152 e o 1114, identificados como C-O de álcool secundário. Novamente, vê-se um grupo indicativo de oxidação.

Os demais picos de 1032, 914, 829, 732, 631 e 530 parecem ser devidos a ligações $\mathrm{C}-\mathrm{H}$, não trazendo informações adicionais às já apresentadas.

\section{5 .2}

Resíduo de Produção de Celulose funcionalizado por ácido nítrico (RPCAN) 


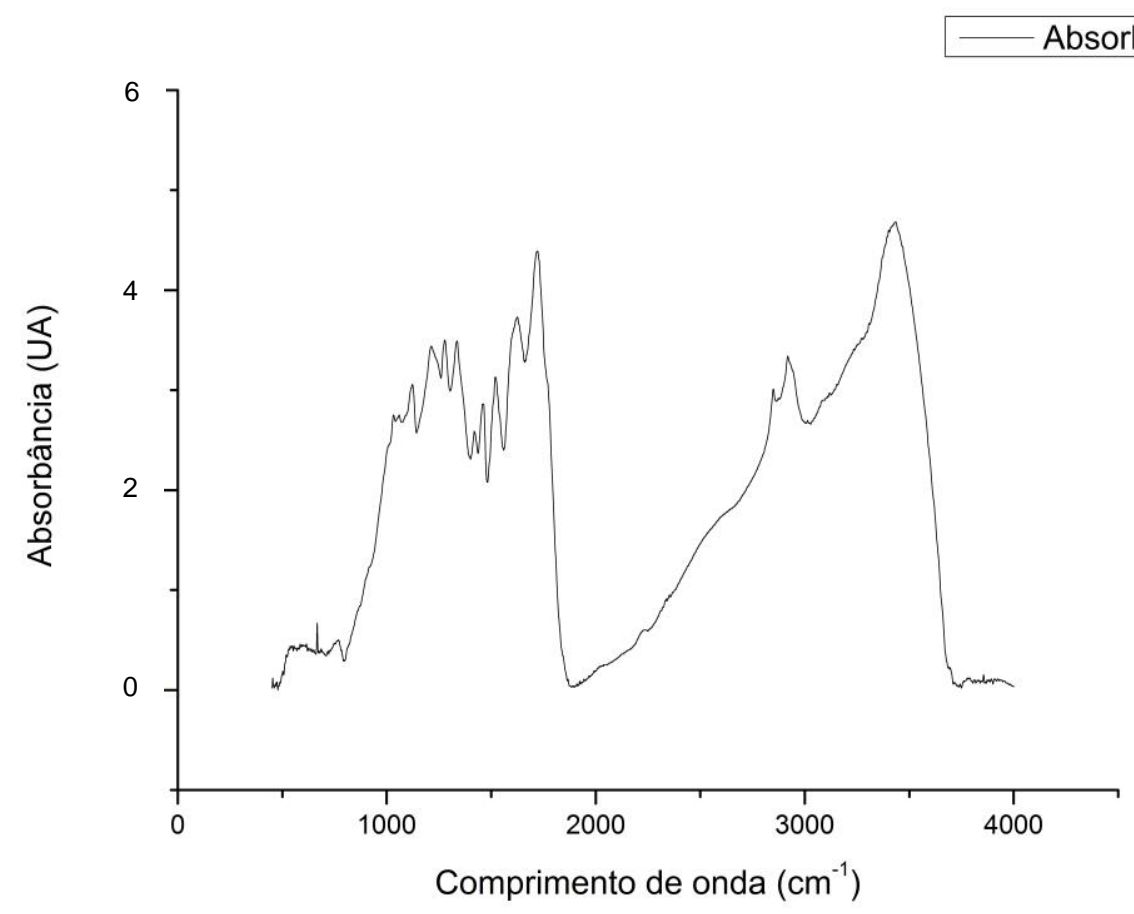

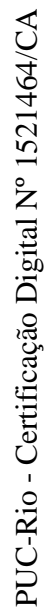

Gráfico 12 - Absorbância x Comprimento de Onda da análise FTIR do resíduo de produção de celulose funcionalizado por ácido nítrico

Lista de picos:

\section{Comprimento de Onda}

\begin{tabular}{|c|}
\hline 3435 \\
\hline 2918 \\
\hline 2850 \\
\hline 1722 \\
\hline 1625 \\
\hline 1520 \\
\hline 1460 \\
\hline 1419 \\
\hline 1335 \\
\hline 1278 \\
\hline 1214 \\
\hline 1123 \\
\hline 1061 \\
\hline 1032 \\
\hline 668 \\
\hline
\end{tabular}


Assim como no RPC, o primeiro pico, em 3435, também parece associado a radicais $\mathrm{OH}$. Da mesma forma, isso sugere que o material venha a ser um bom adsorvente.

Os de 2918 e 2850 associam-se ao C-H aromático. Chama a atenção, contudo, a ausência do pico em 2998, que foi visto no RPC e indicaria C-H aromático. Assim, supõe-se que algumas cadeias aromáticas tenham sido rompidas pelo tratamento com ácido, de modo que novos ligantes, possivelmente oxigenados, podem ter surgido.

O pico de 1722 parece indicar carboxila e o $\mathrm{C}=\mathrm{O}$ conjugado; os de 1625, $\mathrm{C}=\mathrm{C}$ aromática e $\mathrm{C}=\mathrm{O}$; o 1520, C=C; 1460 e 1419, C-H em grupos metílicos; 1335, ésteres e orto-arila; 1278 e 1214, C-O; 1123, C-O de álcoois secundários; e os demais, 1032 e 668, C-H.

Assim, a maior parte dos picos trouxe o mesmo resultado do resíduo não tratado por ácido.

\section{5 .3}

Resíduo de Produção de Celulose funcionalizado por ácido fosfórico (RPCAF) 


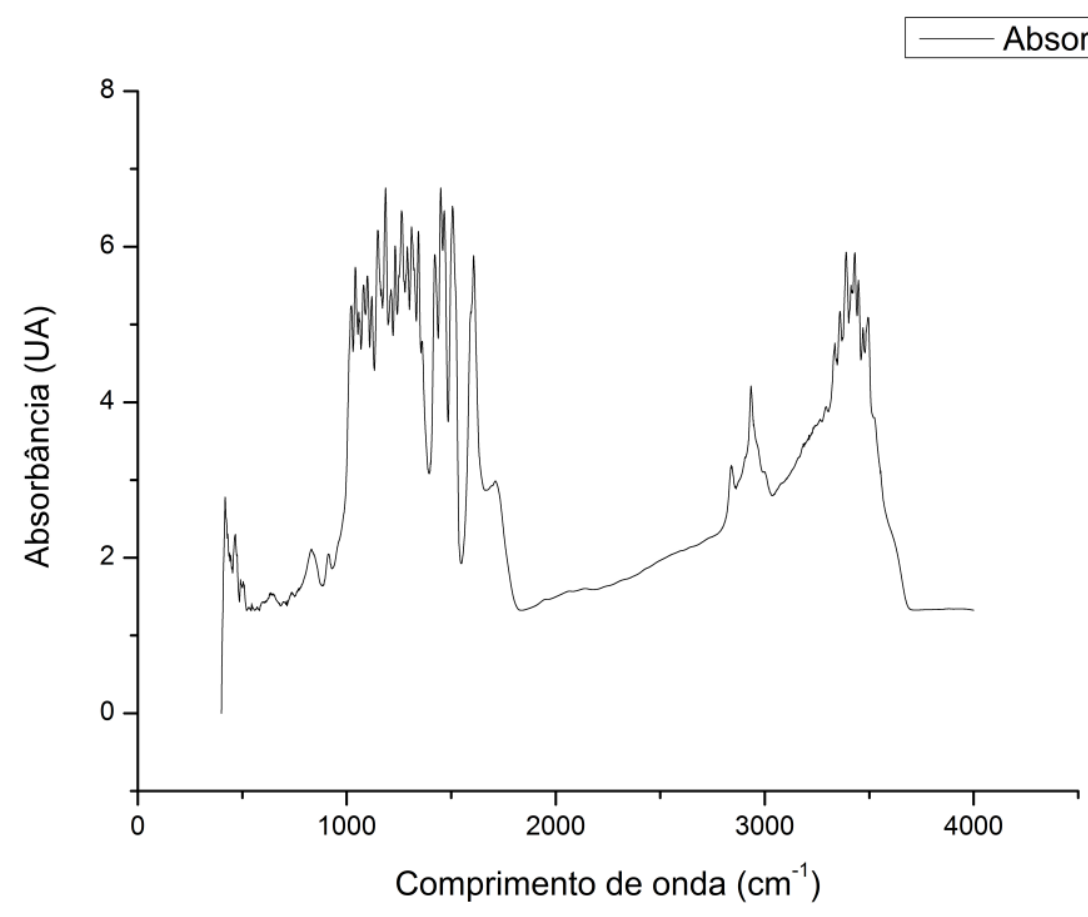

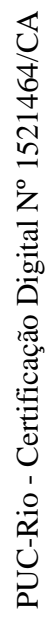

Gráfico 13 - Absorbância x Comprimento de Onda da análise FTIR do resíduo de produção de celulose funcionalizado por ácido fosfórico

Lista de picos:

\begin{tabular}{|c|}
\hline Comprimento de Onda \\
\hline 3496 \\
\hline 3470 \\
\hline 3448 \\
\hline 3431 \\
\hline 3412 \\
\hline 3389 \\
\hline 3359 \\
\hline 3335 \\
\hline 3295 \\
\hline 3005 \\
\hline 2934 \\
\hline 2840 \\
\hline 1711 \\
\hline 1607 \\
\hline 1506 \\
\hline 1467 \\
\hline
\end{tabular}




\begin{tabular}{|c|}
\hline 1450 \\
\hline 1421 \\
\hline 1361 \\
\hline 1343 \\
\hline 1311 \\
\hline 1290 \\
\hline 1263 \\
\hline 1232 \\
\hline 1212 \\
\hline 1186 \\
\hline 1165 \\
\hline 1148 \\
\hline 1120 \\
\hline 1098 \\
\hline 1080 \\
\hline 1058 \\
\hline 1041 \\
\hline 1020 \\
\hline 912 \\
\hline 831 \\
\hline 739 \\
\hline 645 \\
\hline 504 \\
\hline 491 \\
\hline 467 \\
\hline
\end{tabular}

Apesar do maior número de picos, sua tradução revelou os mesmos grupos funcionais do RPC, conforme será listado a seguir.

Os picos entre 3496 e 3295 indicam OH alcoólico e fenólico; 3005, C-H aromática; 2934 e 2840, C-H alifática; 1711, C=O não conjugada; 1607, C=C aromática e $\mathrm{C}=\mathrm{O} ; 1506, \mathrm{C}=\mathrm{C} ; 1467$ a 1421, C-H de grupos metílicos; 1361 a 1212, ésteres e orto-arila; 1186 a 1120, C-O de álcoois secundários; e 1098 a $418 ; \mathrm{C}-\mathrm{H}$.

\section{5 .4}

Resíduo de Produção de Celulose funcionalizado por ácido acético (RPCAA) 


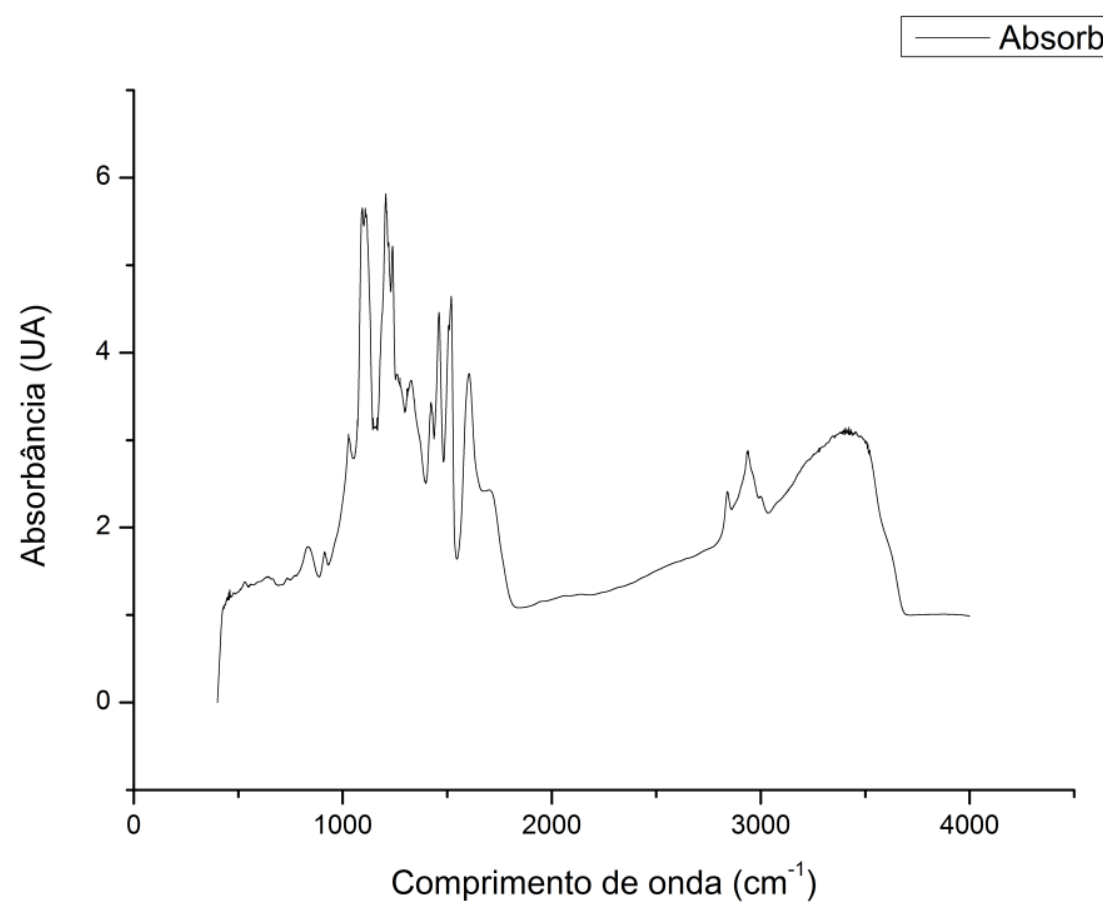

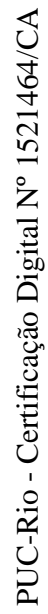

Gráfico 14 - Absorbância x Comprimento de Onda da análise FTIR do resíduo de produção de celulose funcionalizado por ácido acético

Lista de picos:

Comprimento de Onda

\begin{tabular}{|l|}
\hline 3504 \\
\hline 3422 \\
\hline 3390 \\
\hline 2997 \\
\hline 2939 \\
\hline 2839 \\
\hline 1701 \\
\hline 1604 \\
\hline 1519 \\
\hline 1507 \\
\hline 1461 \\
\hline 1421 \\
\hline 1326 \\
\hline 1262 \\
\hline 1239 \\
\hline 1206 \\
\hline
\end{tabular}




\begin{tabular}{|c|}
\hline 1113 \\
\hline 1108 \\
\hline 1094 \\
\hline 1028 \\
\hline 914 \\
\hline 837 \\
\hline 733 \\
\hline 644 \\
\hline 558 \\
\hline 532 \\
\hline 463 \\
\hline
\end{tabular}

Novamente, o gráfico sugeriu os mesmos grupos funcionais do RPC.

Os picos de 3504 a 3390 apontam para OH alcoólico e fenólico; o 2997, C$\mathrm{H}$ aromática; 2939 e 2839, C-H alifática; 1701, carboxila e $\mathrm{C}=\mathrm{O}$ não conjugada; 1604, $\mathrm{C}=\mathrm{C}$ aromática e $\mathrm{C}=\mathrm{O} ; 1507, \mathrm{C}=\mathrm{C} ; 1461$ e 1421, C-H de grupos metílicos; 1326 a 1239, ésteres e orto-arila; 1206, C-O; 1113 a 1028, C-O de álcoois secundários; e 914 a 463, C-H.

\section{6}

\section{Caracterização mecânica do solo}

\section{6 .1}

\section{Granulometria}

A granulometria foi testada apenas para o solo puro, visto que tal propriedade não é função da composição química do material, mas apenas do tamanho de grãos escolhido. Dessa forma, a substituição de parte dos grãos de solo por grãos de RPC não resulta em alterações padronizadas da granulometria, e sim em mudanças arbitrárias, de modo que a repetição dos ensaios não traria conclusões sobre um padrão de mudanças causado pela adição de RPC ao solo.

O resumo dos dados obtidos foi o seguinte: 


\begin{tabular}{|l|r|}
\hline Pedregulho Grosso & $0,0 \%$ \\
\hline Pedregulho Médio & $0,3 \%$ \\
\hline Pedregulho Fino & $0,7 \%$ \\
\hline Areia Grossa & $7,7 \%$ \\
\hline Areia Média & $14,9 \%$ \\
\hline Areia Fina & $12,8 \%$ \\
\hline Silte & $6,2 \%$ \\
\hline Argila & $57,5 \%$ \\
\hline
\end{tabular}

Tabela 10 - Granulometria do solo

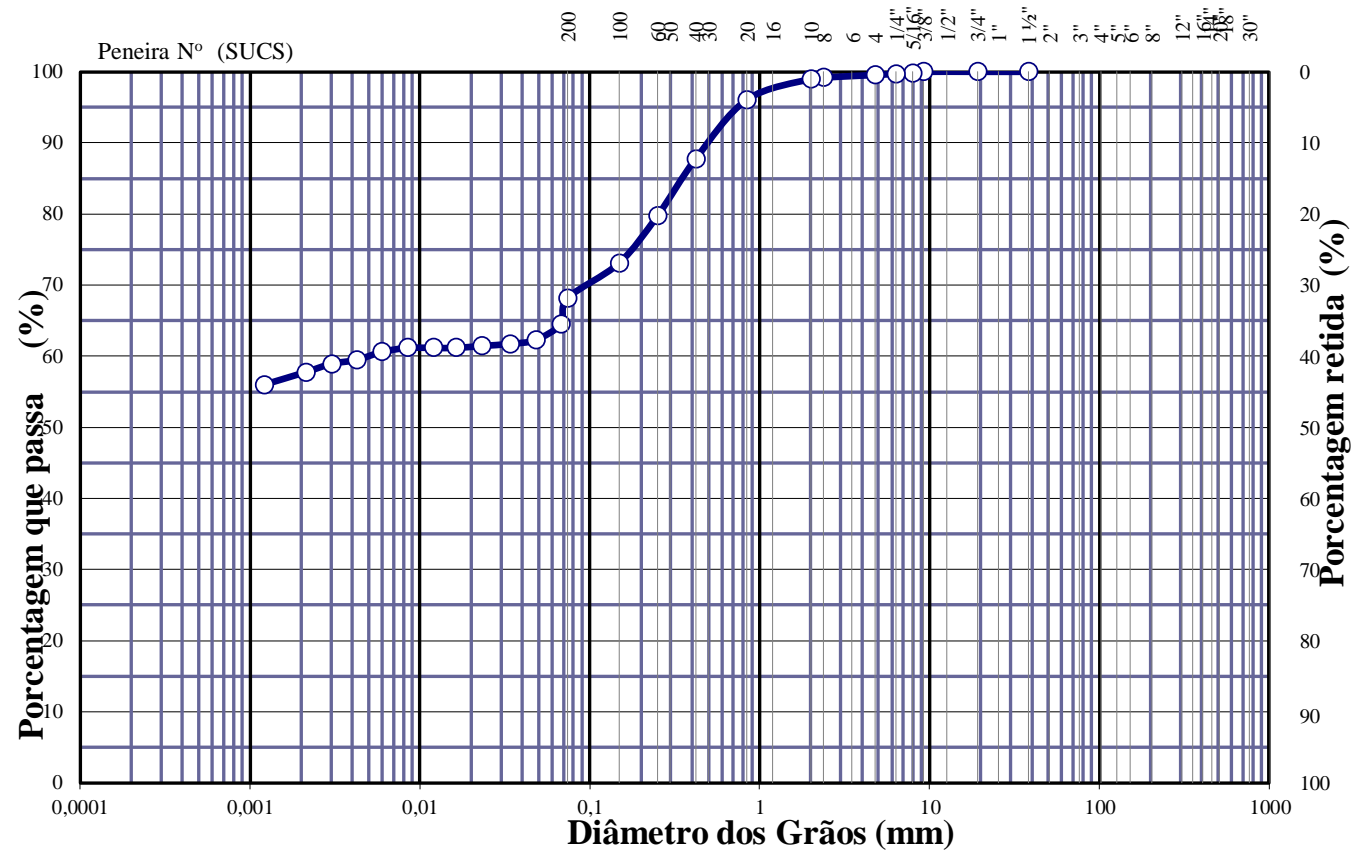

Gráfico 15 - Porcentagem de grãos que passam x Diâmetro dos grãos

Os dados mais detalhados são os seguintes:

Umidade Higroscópica

\begin{tabular}{|rrr||}
\hline Massa caps.+solo+água $=$ & 19,80 & $\mathrm{~g}$ \\
\hline Massa cap.+solo $=$ & 19,67 & $\mathrm{~g}$ \\
\hline Massa água $=$ & 0,13 & $\mathrm{~g}$ \\
\hline Tara $=$ & 8,38 & $\mathrm{~g}$ \\
\hline
\end{tabular}




\begin{tabular}{rcc||} 
Massa solo $=$ & 11,29 & $\mathrm{~g}$ \\
\hline Umidade $=$ & 1,15 & $\%$ \\
\hline Fator de correção $=$ & 0,99 \\
\hline Cápsula no. $=$ & 5 \\
\hline
\end{tabular}

Tabela 11 - Umidade higroscópica do solo

\section{Amostra Total Seca}

\begin{tabular}{|rrr||}
\hline Massa da amostra seca ao ar $=$ & 1560 & G \\
\hline Massa da amostra seca na estufa retida na \# 40 $=$ & 189,12 & G \\
\hline Massa da amostra seca ao ar passando na \# 40 $=$ & 1370,88 & G \\
\hline Massa da água $=$ & 15,61 & G \\
\hline Massa da amos. seca na estufa passando \# 40 $=$ & 1355,27 & G \\
\hline Massa da amostra total seca na estufa $=$ & 1544,39 & $\mathrm{G}$ \\
\hline
\end{tabular}

Tabela 12 - Amostra total seca

\section{Peneiramento da Amostra Total}

\begin{tabular}{|c|c|c|c|c|c|c|c|}
\hline \multicolumn{3}{|c|}{ Peneira } & \multicolumn{4}{|c|}{ Material retido } & \multirow{3}{*}{$\begin{array}{c}\% \text { da Am. } \\
\text { total que } \\
\text { passa } \\
\end{array}$} \\
\hline \multicolumn{2}{|c|}{ Abertura da malha } & \multirow{2}{*}{$\begin{array}{c}\text { Massa } \\
\text { (g) }\end{array}$} & \multirow{2}{*}{$\begin{array}{c}\text { Massa } \\
\text { total (g) }\end{array}$} & \multirow{2}{*}{$\begin{array}{c}\text { Massa do } \\
\text { solo (g) }\end{array}$} & \multirow{2}{*}{$\begin{array}{c}\% \text { da Am. } \\
\text { Total }\end{array}$} & \multirow{2}{*}{$\begin{array}{c}\% \\
\text { Acumul. }\end{array}$} & \\
\hline$\#$ & Mm & & & & & & \\
\hline $11 / 2$ & 38,10 & 0,00 & 0,00 & 0,00 & 0 & 0 & 100,00 \\
\hline $3 / 4$ & 19,10 & 0,00 & 0,00 & 0,00 & 0 & 0 & 100,00 \\
\hline $3 / 8$ & 9,25 & 501,92 & 501,92 & 0,00 & 0 & 0 & 100,00 \\
\hline $5 / 16$ & 7,93 & 517,39 & 520,07 & 2,68 & 0 & 0 & 99,83 \\
\hline $1 / 4$ & 6,35 & 510,60 & 512,45 & 1,85 & 0 & 0 & 99,71 \\
\hline 4 & 4,76 & 477,14 & 479,57 & 2,43 & 0 & 0 & 99,55 \\
\hline 8 & 2,38 & 422,76 & 428,23 & 5,47 & 0 & 1 & 99,20 \\
\hline 10 & 2,00 & 371,45 & 374,40 & 2,95 & 0 & 1 & 99,00 \\
\hline 20 & 0,84 & 479,94 & 525,24 & 45,30 & 3 & 4 & 96,07 \\
\hline 40 & 0,42 & 413,60 & 542,04 & 128,44 & 8,32 & 12,25 & 87,75 \\
\hline
\end{tabular}

Tabela 13 - Peneiramento da amostra total 
Peneiramento da Amostra Parcial

\begin{tabular}{|c|c|c|c|c|c|c|c|}
\hline \multicolumn{3}{|c|}{ M. am. seca ao ar $=\quad 50,00$} & \multicolumn{3}{|c|}{ g Massa da am. parcial corr. $=$} & 49,43 & $\mathbf{G}$ \\
\hline \multicolumn{3}{|c|}{ Peneira } & \multicolumn{4}{|c|}{ Material retido } & \multirow{3}{*}{$\begin{array}{c}\% \text { da Am. } \\
\text { total que } \\
\text { passa } \\
\end{array}$} \\
\hline \multicolumn{2}{|c|}{ Abertura da malha } & \multirow{2}{*}{$\begin{array}{c}\text { Massa } \\
(\mathrm{g}) \\
\end{array}$} & \multirow{2}{*}{$\begin{array}{c}\text { Massa } \\
\text { total (g) }\end{array}$} & \multirow{2}{*}{$\begin{array}{c}\text { Massa do } \\
\text { solo (g) } \\
\end{array}$} & \multirow{2}{*}{$\begin{array}{c}\% \text { da Am. } \\
\text { Parcial } \\
\end{array}$} & \multirow{2}{*}{$\begin{array}{c}\% \\
\text { Acumul. }\end{array}$} & \\
\hline$\#$ & Mm & & & & & & \\
\hline 60 & 0,250 & 346,78 & 351,30 & 4,52 & 9,14 & 9,14 & 79,73 \\
\hline 100 & 0,149 & 327,30 & 331,03 & 3,73 & 7,55 & 16,69 & 73,11 \\
\hline 200 & 0,074 & 322,48 & 325,27 & 2,79 & 5,64 & 22,33 & 68,16 \\
\hline
\end{tabular}

Tabela 14 - Peneiramento da amostra parcial

\section{Sedimentação}

\begin{tabular}{|c|c|c|c|c|c|c|c|}
\hline \multicolumn{2}{|c|}{$\begin{array}{c}\text { № do densímetro = } \\
\text { Correção inicial = }\end{array}$} & \multirow{2}{*}{$\begin{array}{c}2353-03 \\
2,00 \\
\begin{array}{c}\text { Leit.do } \\
\text { dens. }\end{array}\end{array}$} & \multicolumn{3}{|c|}{$\begin{array}{c}\text { Massa específica dos grãos= } \\
\text { Correção devido ao menisco }=\end{array}$} & \multirow{2}{*}{$\begin{array}{c}2,723 \\
1,00 \\
\text { Altura de } \\
\text { queda }(\mathrm{cm})\end{array}$} & \multirow{2}{*}{$\begin{array}{c}\mathbf{g} / \mathrm{cm}^{3} \\
\text { Diâmetro } \\
(\mathbf{m m})\end{array}$} \\
\hline $\begin{array}{l}\text { Tempo } \\
(\min )\end{array}$ & $\begin{array}{l}\text { Tempera- } \\
\text { tura }\left({ }^{\circ} \mathrm{C}\right)\end{array}$ & & $\begin{array}{l}\text { Leit. cor- } \\
\text { rigida }\end{array}$ & $\begin{array}{c}\% \text { da Am. } \\
\text { Parcial }\end{array}$ & $\begin{array}{c}\% \text { da Am. } \\
\text { total }\end{array}$ & & \\
\hline 0,5 & 22,0 & 24,7 & 23,03 & 73,543 & 64,538 & 13,34 & 0,06742 \\
\hline 1 & 22,0 & 23,9 & 22,23 & 70,982 & 62,290 & 13,51 & 0,04797 \\
\hline 2 & 22,0 & 23,7 & 22,03 & 70,341 & 61,728 & 13,55 & 0,03398 \\
\hline 4 & 22,0 & 23,6 & 21,93 & 70,021 & 61,447 & 12,55 & 0,02312 \\
\hline 8 & 22,0 & 23,5 & 21,83 & 69,701 & 61,166 & 12,57 & 0,01636 \\
\hline 15 & 22,0 & 23,5 & 21,83 & 69,701 & 61,166 & 12,57 & 0,01195 \\
\hline 30 & 22,0 & 23,5 & 21,83 & 69,701 & 61,166 & 12,57 & 0,00845 \\
\hline 60 & 22,0 & 23,3 & 21,63 & 69,061 & 60,604 & 12,61 & 0,00599 \\
\hline 120 & 22,0 & 22,9 & 21,23 & 67,780 & 59,480 & 12,70 & 0,00425 \\
\hline 240 & 22,0 & 22,7 & 21,03 & 67,139 & 58,918 & 12,74 & 0,00301 \\
\hline 480 & 22,5 & 22,2 & 20,61 & 65,814 & 57,755 & 12,85 & 0,00212 \\
\hline 1440 & 24,2 & 21,2 & 19,99 & 63,810 & 55,996 & 13,06 & 0,00121 \\
\hline
\end{tabular}

Tabela 15 - Sedimentação

Ao observar a análise granulométrica do solo puro, o que mais chama a atenção é a ampla predominância da fração argila. Isso ratifica a adequação de tal solo aos objetivos do trabalho, visto que, nessa faixa, ele possui maior porosidade, sendo propício ao armazenamento de água e outros nutrientes; e 
maior relação superfície-volume, o que favorece mecanismos de adsorção, devido ao maior contato dos grãos com as substâncias a serem aderidas.

A granulometria da lignina foi restrita arbitrariamente à passante na peneira Mesh 40 (0,042 mm), a fim de ser compatível com a usada nos ensaios de plasticidade e liquidez das normas técnicas usadas. Assim, o tamanho dos grãos não é relevante para as conclusões deste material no escopo da pesquisa.

\section{6 .2}

\section{Massa Específica dos Grãos}

Tal propriedade também foi testada somente para o solo original, apenas para trazer maior objetividade na descrição do solo testado e criar um melhor parâmetro de comparação para eventuais testes futuros com outros solos. O resultado foi:

\begin{tabular}{|l|r|}
\hline Massa Específica dos grãos & 2,72 \\
\hline
\end{tabular}

Os dados detalhados são:

\begin{tabular}{|c|c|c|c|c|c|c|}
\hline $\begin{array}{c}\text { Balão } \\
\text { volumétrico }\end{array}$ & $\begin{array}{c}\text { Volume } \\
\text { Nominal } \\
\left(\mathrm{cm}^{3}\right)\end{array}$ & $\begin{array}{c}\text { Temperatura } \\
\left({ }^{\circ} \mathrm{C}\right)\end{array}$ & $\begin{array}{c}\text { Massa de } \\
\text { sólidos }(\mathrm{g})\end{array}$ & $\begin{array}{c}\text { Massa de } \\
\text { picnômetro }+ \\
\text { água + solo } \\
(\mathrm{g})\end{array}$ & $\begin{array}{c}\text { Massa de } \\
\text { picnômetro }+ \\
\text { água }(\mathrm{g})\end{array}$ & $\begin{array}{c}\text { Massa } \\
\text { Específica } \\
\text { dos grãos } \\
\left(\mathrm{g} / \mathrm{cm}^{3}\right)\end{array}$ \\
\hline a & 250 & 24 & 25 & 334,38 & 318,58 & 2,7101 \\
\hline b & 250 & 24 & 25 & 338,09 & 322,21 & 2,7338 \\
\hline c & 250 & 24 & 25 & 337,61 & 321,76 & 2,7249 \\
\hline Média & & & & & & 2,7229 \\
\hline
\end{tabular}

Tabela 16 - Massa específica dos grãos

A massa específica dos grãos, no valor de 2,72; é típica de minerais de quartzo. Logo, fica registrado que os testes do RPC foram feitos com esse material, podendo diferir de experimentos feitos com solos de outra mineralogia. 


\section{6 .3}

\section{Limites de Atterberg}

Tais limites foram calculados para 4 tipos de amostra: solo puro, solo com $1 \%$ de RPC, solo com 5\% de RPC e solo com 10\% de RPC. Também foi avaliada a plasticidade do RPC puro. Essa variedade de testes foi feita para se observar o efeito do RPC sobre a plasticidade e liquidez do solo.

Para efeitos de comparação, a tabela com os resultados em cada amostra é a seguinte, considerando-se:

$\mathrm{SP}=$ Solo puro

$\mathrm{SCn}=$ Solo com composto (RPC) na porcentagem $\mathrm{n}$.

\begin{tabular}{|l|c|c|c|c|}
\hline & SP & SC1 & SC5 & SC10 \\
\hline Limite de Plasticidade & $31,26 \%$ & $27,82 \%$ & $31,93 \%$ & $31,40 \%$ \\
\hline Limite de Liquidez & $55,17 \%$ & $60,83 \%$ & $60,07 \%$ & $65,42 \%$ \\
\hline Índice de Plasticidade & $23,91 \%$ & $33,01 \%$ & $28,14 \%$ & $34,01 \%$ \\
\hline
\end{tabular}

Tabela 17 - Resumo dos limites de Atterberg das amostras de solo com 0\%, 1\%, $5 \%$ e $10 \%$ de RPC.

Para uma maior explicação, os resultados de cada amostra serão exibidos a seguir.

\subsubsection{1}

\section{RPC puro}

Não foi possível obter o cilindro de $3 \mathrm{~mm}$ de diâmetro. Nesse caso, de acordo com a NBR 7180, a amostra de lignina foi considerada como não apresentando limite de plasticidade.

Consequentemente, ela não foi testada para o limite de liquidez. 


\subsubsection{2}

\section{Solo puro}

O resumo dos limites foi o seguinte:

\begin{tabular}{|l|r|}
\hline Limite de Plasticidade & $31,26 \%$ \\
\hline Limite de Liquidez & $55,17 \%$ \\
\hline Índice de Plasticidade & $23,91 \%$ \\
\hline
\end{tabular}

Tabela 18 - Limites de Atterberg do solo puro

Detalhando-se os dados:

\section{Plasticidade}

\begin{tabular}{|r|c|c|c|c|}
\hline Amostra & $\begin{array}{c}\text { Massa de sólidos, } \\
\text { água e recipiente (g) }\end{array}$ & $\begin{array}{c}\text { Massa de sólidos } \\
\text { e recipiente }(\mathrm{g})\end{array}$ & $\begin{array}{c}\text { Massa do } \\
\text { recipiente }(\mathrm{g})\end{array}$ & Umidade \\
\hline 17 & 7,91 & 7,66 & 6,89 & $32,47 \%$ \\
\hline 131 & 8,17 & 7,88 & 7,00 & $32,95 \%$ \\
\hline 200 & 9,13 & 8,87 & 7,99 & $29,55 \%$ \\
\hline 159 & 7,02 & 6,82 & 6,21 & $32,79 \%$ \\
\hline 95 & 7,61 & 7,42 & 6,78 & $29,69 \%$ \\
\hline 132 & 7,87 & 7,62 & 6,79 & $30,12 \%$ \\
\hline Média & & & & $31,26 \%$ \\
\hline
\end{tabular}

Tabela 19 - Limite de plasticidade do solo puro

Liquidez

Massa de sólidos, $\quad$ Massa de

água e recipiente

(g) sólidos e recipiente $(g)$

\section{Massa do}

recipiente (g)

\begin{tabular}{|c|c|c|c|c|c|c|c|}
\hline 17 & 11,34 & 9,57 & 6,89 & $66,04 \%$ & 14 & 1,146128036 & $64,30 \%$ \\
\hline 5 & 12,85 & 10,56 & 6,68 & $59,02 \%$ & 20 & 1,301029996 & $58,69 \%$ \\
\hline
\end{tabular}




\begin{tabular}{|l|l|l|l|l|l|l|l|}
200 & 16,29 & 13,48 & 7,99 & $51,18 \%$ & 27 & 1,431363764 & $53,96 \%$ \\
\hline 132 & 15,52 & 12,60 & 6,79 & $50,26 \%$ & 30 & 1,477121255 & $52,30 \%$ \\
\hline 131 & 15,78 & 12,92 & 7,00 & $48,31 \%$ & 46 & 1,662757832 & $45,57 \%$ \\
\hline
\end{tabular}

Tabela 20 - Limite de liquidez do solo puro

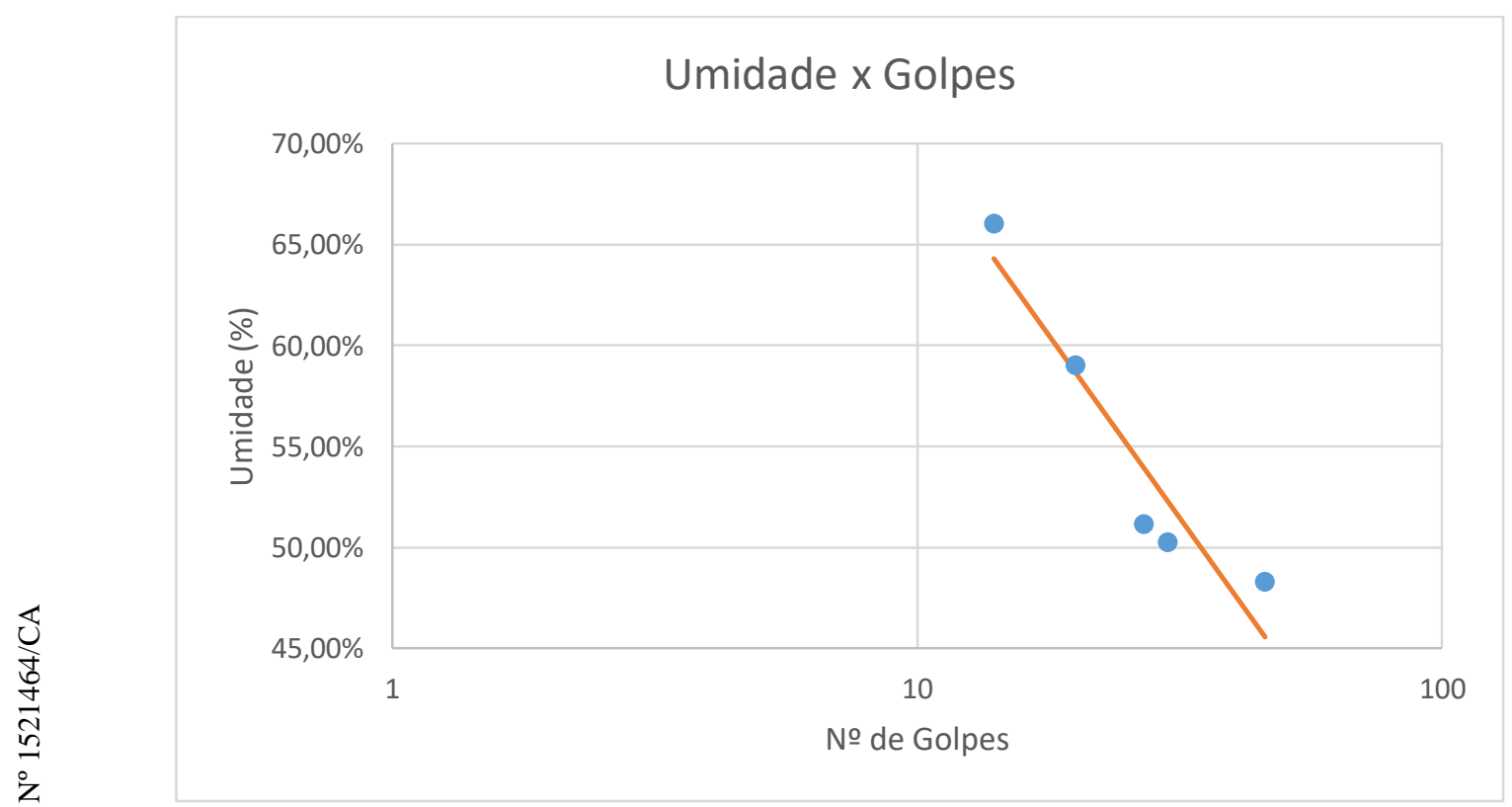

Gráfico 16 - Umidade x Golpes no teste de limite de liquidez do solo puro

\begin{tabular}{|l|r|}
\hline $\log (25)$ & 1,397940009 \\
\hline Coef Ang & $-0,362582673$ \\
\hline Coef Lin & 1,058586814 \\
\hline
\end{tabular}

Tabela 21 - Coeficientes do gráfico 16

\subsubsection{3}

Solo com $1 \%$ de RPC

\begin{tabular}{|l|r|}
\hline Limite de Plasticidade & $27,82 \%$ \\
\hline Limite de Liquidez & $60,83 \%$ \\
\hline Índice de Plasticidade & $33,01 \%$ \\
\hline
\end{tabular}


Tabela 22 - Limites de Atterberg do solo com 1\% de resíduo de produção de celulose

Plasticidade

\begin{tabular}{|r|c|c|c|c|}
\hline Amostra & $\begin{array}{c}\text { Massa de sólidos, } \\
\text { água e recipiente }(\mathrm{g})\end{array}$ & $\begin{array}{c}\text { Massa de sólidos } \\
\text { e recipiente }(\mathrm{g})\end{array}$ & $\begin{array}{c}\text { Massa do } \\
\text { recipiente }(\mathrm{g})\end{array}$ & Umidade \\
\hline 124 & 9,81 & 9,49 & 8,33 & $27,59 \%$ \\
\hline 22 & 9,19 & 8,81 & 7,44 & $27,74 \%$ \\
\hline 50 & 9,67 & 9,31 & 8,05 & $28,57 \%$ \\
\hline A124 & 7,81 & 7,41 & 5,95 & $27,40 \%$ \\
\hline Média & & & & $27,82 \%$ \\
\hline
\end{tabular}

Tabela 23 - Limite de plasticidade do solo com $1 \%$ de resíduo de produção de celulose

Liquidez

Massa de sólidos,

Massa de sólidos e (g) recipiente $(\mathrm{g})$

\section{Massa do} recipiente (g)

Umidade Golpes $\quad$ Log N

Umidade por

ostra água e recipiente

(g)

\begin{tabular}{l|l}
.77 & 9,7 \\
\hline 1
\end{tabular}

1

39

142

9,77

9,89

9,16

9,76

\begin{tabular}{|l|l|l|l|l|l|}
\hline 8,86 & 7,65 & $75,21 \%$ & 13 & 1,113943352 & $76,25 \%$ \\
\hline 9,01 & 7,75 & $69,84 \%$ & 18 & 1,255272505 & $68,58 \%$ \\
\hline 8,58 & 7,62 & $60,42 \%$ & 26 & 1,414973348 & $59,91 \%$ \\
\hline 8,87 & 7,12 & $50,86 \%$ & 37 & 1,568201724 & $51,59 \%$ \\
\hline
\end{tabular}

7,65

75,20

$7521 \%$

1,113943352

Regressão Linear

Tabela 24 - Limite de liquidez do solo com 1\% de resíduo de produção de celulose 


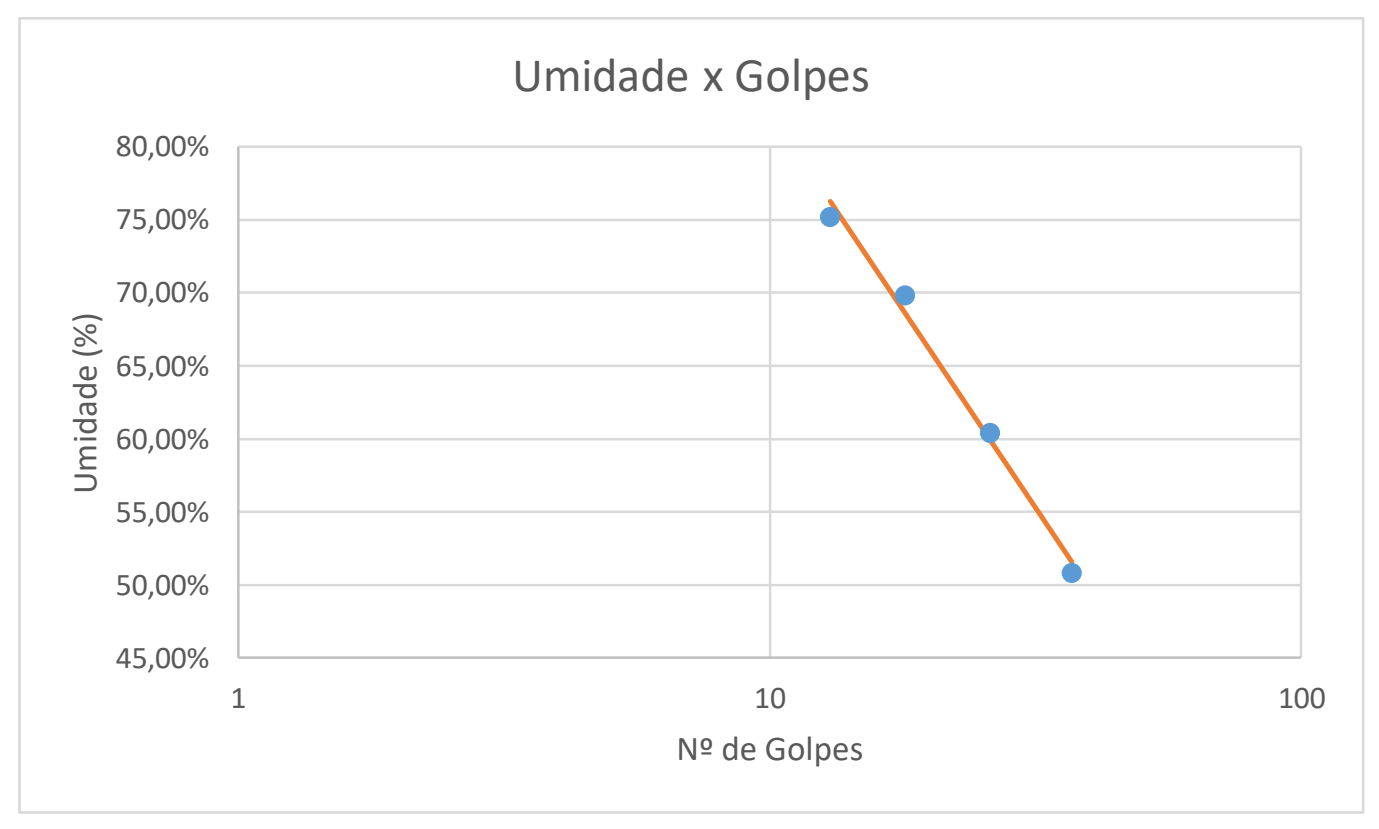

Gráfico 17 - Umidade x Golpes no teste de limite de liquidez do solo com 1\% de resíduo de produção de celulose

\begin{tabular}{|l|r|}
\hline $\log (25)$ & 1,397940009 \\
\hline Coef Ang & $-0,542889992$ \\
\hline Coef Lin & 1,367244095 \\
\hline
\end{tabular}

Tabela 25 - Coeficientes do gráfico 17

\subsubsection{4}

Solo com $5 \%$ de RPC

\begin{tabular}{|l|r|}
\hline Limite de Plasticidade & $31,93 \%$ \\
\hline Limite de Liquidez & $60,07 \%$ \\
\hline Índice de Plasticidade & $28,14 \%$ \\
\hline
\end{tabular}

Tabela 26 - Limites de Atterberg do solo com 5\% de resíduo de produção de celulose 
Plasticidade

\begin{tabular}{|r|c|c|c|c|}
\hline Amostra & $\begin{array}{c}\text { Massa de sólidos, } \\
\text { água e recipiente }(\mathrm{g})\end{array}$ & $\begin{array}{c}\text { Massa de sólidos } \\
\text { e recipiente }(\mathrm{g})\end{array}$ & $\begin{array}{c}\text { Massa do } \\
\text { recipiente }(\mathrm{g})\end{array}$ & Umidade \\
\hline 414 & 5,44 & 5,12 & 4,11 & $31,68 \%$ \\
\hline 17 & 8,05 & 7,77 & 6,88 & $31,46 \%$ \\
\hline 66 & 9,56 & 9,24 & 8,26 & $32,65 \%$ \\
\hline Média & & & & $31,93 \%$ \\
\hline
\end{tabular}

Tabela 27 - Limite de plasticidade do solo com 5\% de resíduo de produção de celulose

Liquidez

\begin{tabular}{|c|c|c|c|c|c|c|c|}
\hline Amostra & $\begin{array}{l}\text { Massa de sólidos, } \\
\text { água e recipiente } \\
\text { (g) }\end{array}$ & $\begin{array}{l}\text { Massa de } \\
\text { sólidos e } \\
\text { recipiente (g) }\end{array}$ & $\begin{array}{c}\text { Massa do } \\
\text { recipiente (g) }\end{array}$ & Umidade & Golpes & $\log N$ & $\begin{array}{c}\text { Umidade por } \\
\text { Regressão } \\
\text { Linear }\end{array}$ \\
\hline . 12 & 9,67 & 8,86 & 7,77 & $74,31 \%$ & 13 & 1,113943352 & $71,48 \%$ \\
\hline 5 & 9,84 & 8,89 & 7,34 & $61,29 \%$ & 21 & 1,322219295 & $63,11 \%$ \\
\hline$\vec{n} 82 \mathrm{~B}$ & 9,45 & 7,89 & 5,15 & $56,93 \%$ & 26 & 1,414973348 & $59,39 \%$ \\
\hline 2 & 11,30 & 10,34 & 8,44 & $50,53 \%$ & 39 & 1,591064607 & $52,32 \%$ \\
\hline 1 & 14,52 & 13,24 & 10,69 & $50,20 \%$ & 53 & 1,72427587 & $46,97 \%$ \\
\hline
\end{tabular}

Tabela 28 - Limite de liquidez do solo com 1\% de resíduo de produção de celulose

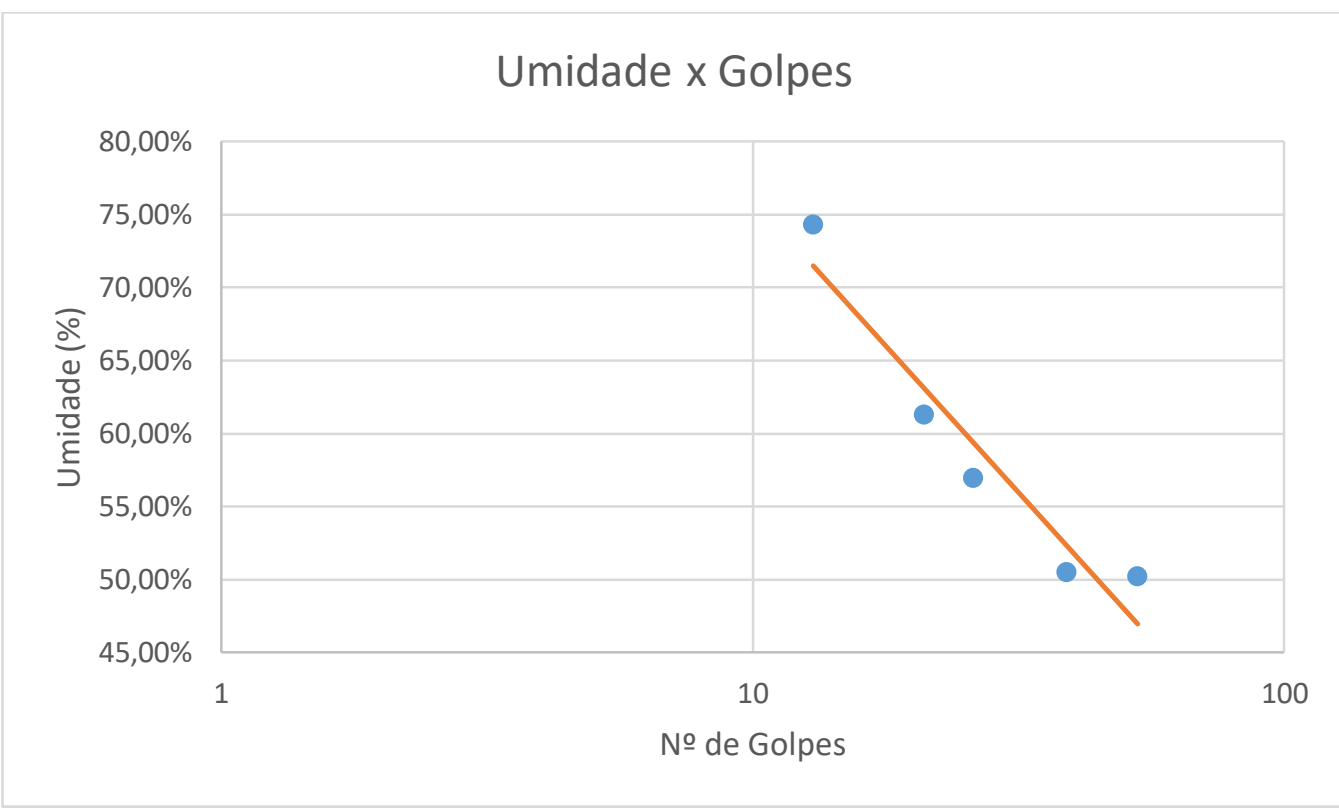


Gráfico 18 - Umidade x Golpes no teste de limite de liquidez do solo com 5\% de resíduo de produção de celulose

\begin{tabular}{|l|r|}
\hline $\log (25)$ & 1,397940009 \\
\hline Coef Ang & $-0,401618942$ \\
\hline Coef Lin & 1,162156439 \\
\hline
\end{tabular}

Tabela 29 - Coeficientes do gráfico 18

\subsubsection{5}

\section{Solo com $10 \%$ de RPC}

\begin{tabular}{|l|r|}
\hline Limite de Plasticidade & $31,40 \%$ \\
\hline Limite de Liquidez & $65,42 \%$ \\
\hline Índice de Plasticidade & $34,01 \%$ \\
\hline
\end{tabular}

Tabela 30 - Limites de Atterberg do solo com 10\% de resíduo de produção de celulose

Plasticidade

\begin{tabular}{|r|c|c|c|c|}
\hline Amostra & $\begin{array}{c}\text { Massa de sólidos, } \\
\text { água e recipiente }(\mathrm{g})\end{array}$ & $\begin{array}{c}\text { Massa de sólidos } \\
\text { e recipiente }(\mathrm{g})\end{array}$ & $\begin{array}{c}\text { Massa do } \\
\text { recipiente }(\mathrm{g})\end{array}$ & Umidade \\
\hline 146 & 9,16 & 8,94 & 8,20 & $29,73 \%$ \\
\hline 65 & 7,95 & 7,74 & 7,01 & $28,77 \%$ \\
\hline A138 & 7,07 & 6,82 & 6,12 & $35,71 \%$ \\
\hline Média & & & & $31,40 \%$ \\
\hline
\end{tabular}

Tabela 31 - Limite de plasticidade do solo com $10 \%$ de resíduo de produção de celulose

Liquidez 


\begin{tabular}{|c|c|c|c|c|c|c|c|}
\hline Amostra & $\begin{array}{c}\text { Massa de sólidos, } \\
\text { água e recipiente } \\
(\mathrm{g})\end{array}$ & $\begin{array}{c}\text { Massa de } \\
\text { sólidos e } \\
\text { recipiente }(\mathrm{g})\end{array}$ & $\begin{array}{c}\text { Massa do } \\
\text { recipiente }(\mathrm{g})\end{array}$ & Umidade & Golpes & Log N & $\begin{array}{c}\text { Umidade por } \\
\text { Regressão } \\
\text { Linear }\end{array}$ \\
\hline 124 & 9,98 & 9,26 & 8,32 & $76,60 \%$ & 13 & 1,113943352 & $75,76 \%$ \\
\hline A124 & 8,18 & 7,25 & 5,95 & $71,54 \%$ & 19 & 1,278753601 & $69,76 \%$ \\
\hline 22 & 9,82 & 8,93 & 7,43 & $59,33 \%$ & 29 & 1,462397998 & $63,07 \%$ \\
\hline 50 & 10,08 & 9,35 & 8,05 & $56,15 \%$ & 42 & 1,62324929 & $57,21 \%$ \\
\hline A084 & 8,68 & 7,77 & 6,02 & $52,00 \%$ & 67 & 1,826074803 & $49,83 \%$ \\
\hline
\end{tabular}

Tabela 32 - Limite de liquidez do solo com 1\% de resíduo de produção de celulose

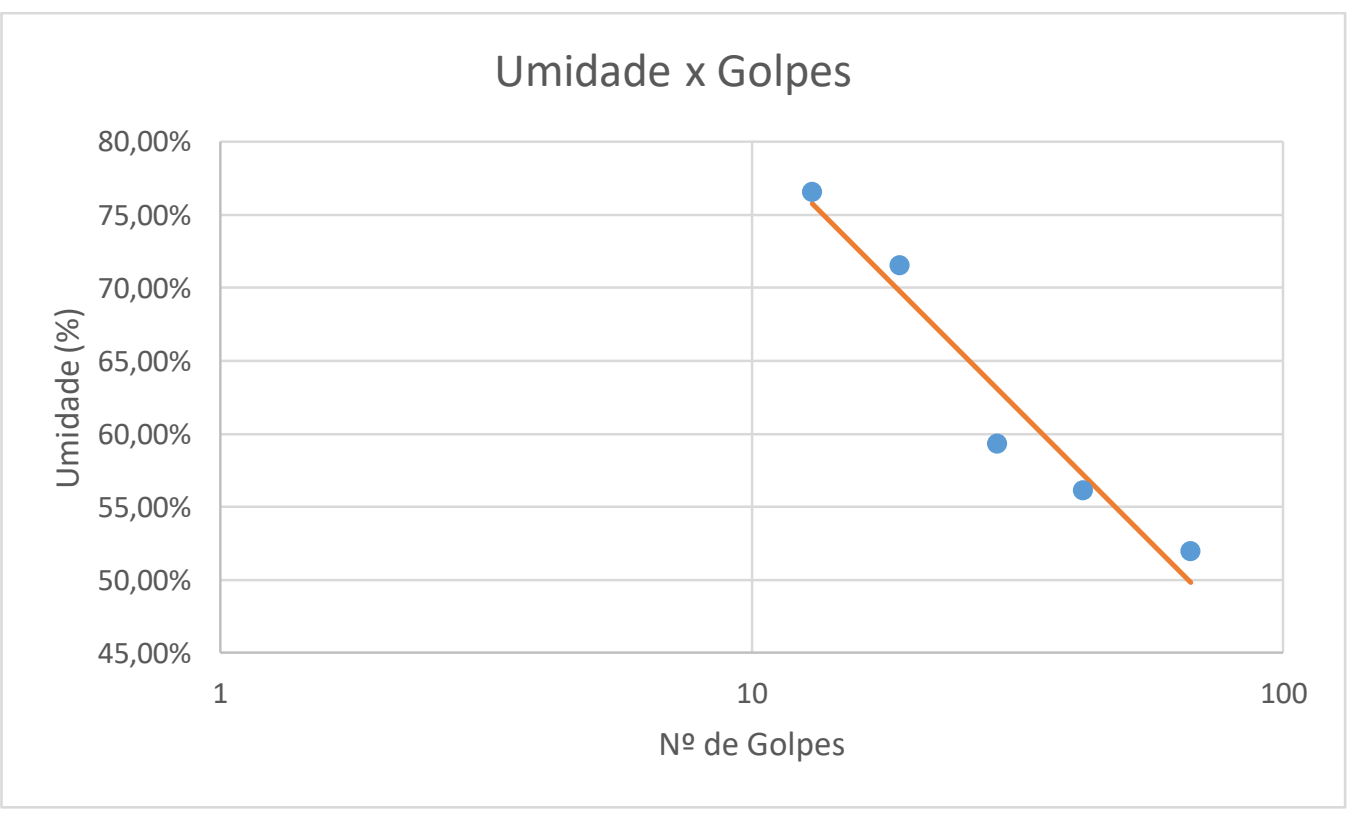

Gráfico 19 - Umidade x Golpes no teste de limite de liquidez do solo com 10\% de resíduo de produção de celulose

\begin{tabular}{|l|r|}
\hline $\log (25)$ & 1,397940009 \\
\hline Coef Ang & $-0,364104958$ \\
\hline Coef Lin & 1,163157809 \\
\hline
\end{tabular}

Tabela 33 - Coeficientes do gráfico 19

A plasticidade do solo puro apresentou um valor considerável e distante dos extremos de $0 \%$ e $100 \%$, exibindo-se como um adequado parâmetro para 
comparação com diferentes misturas. O RPC puro, por sua vez, mostrou não ter plasticidade, o que sugere que poderia reduzir o LP da mistura com o solo. Porém, nos teste de plasticidade das 3 misturas de solo com lignina, o valor ficou muito próximo daquele do solo puro, o que indicou que a adição de lignina, nos teores adotados, não influencia no limite de plasticidade do solo.

O limite de liquidez do solo puro também se configurou como um bom parâmetro inicial, por guardar considerável distância dos extremos. No teste do LL, viu-se que o acréscimo de lignina tende a aumentar o limite de liquidez do solo. Tal aumento pode ser benéfico ao meio ambiente, visto que protege o solo contra a erosão causada pela água, uma vez que o maior LL faz com que seja necessária uma maior entrada de água para que o conjunto passe a fluir e, por consequência, o solo seja perdido. Logo, os testes sugeriram que a mistura de lignina ao solo pode trazer a ele um benefício.

\section{7}

\section{Capacidade de Troca Catiônica}

Após a realização dos procedimentos descritos em "Materiais e Métodos", obtiveram-se os seguintes resultados e interpretações. A tabela 30 exibe o resultado de cada amostra, estando $\mathrm{Na}$ e $\mathrm{K}$ em $\mathrm{mg} / \mathrm{dm}^{3}$ e os demais em cmolc/dm .

\begin{tabular}{|c|c|c|c|c|c|c|c|c|c|c|c|}
\hline Amostra & $\begin{array}{l}\mathrm{Na} \\
(\mathrm{mg} / \\
\left.\mathrm{cm}^{3}\right)\end{array}$ & $\begin{array}{c}\mathrm{Al} \\
\left(\mathrm{cmolc}^{2} /\right. \\
\left.\mathrm{cm}^{3}\right)\end{array}$ & $\begin{array}{c}\mathrm{H}^{+} \\
\left(\mathrm{cmolc}^{2} /\right. \\
\left.\mathrm{cm}^{3}\right)\end{array}$ & $\begin{array}{c}\mathrm{Ca} \\
\left(\mathrm{cmolc}^{2}\right. \\
\left.\mathrm{cm}^{3}\right)\end{array}$ & $\begin{array}{c}\mathrm{Mg} \\
\left(\mathrm{cmolc}^{2} /\right. \\
\left.\mathrm{cm}^{3}\right)\end{array}$ & $\begin{array}{c}\mathrm{K} \\
(\mathrm{mg} / \\
\left.\mathrm{cm}^{3}\right)\end{array}$ & $\begin{array}{c}\text { Acidez } \\
\text { Potencial } \\
\left(\mathrm{cmolc}^{2}\right. \\
\left.\mathrm{cm}^{3}\right)\end{array}$ & $\begin{array}{c}\text { Valor } \\
\mathrm{S} \\
\left(\mathrm{cmolc}^{2} /\right. \\
\left.\mathrm{cm}^{3}\right)\end{array}$ & $\begin{array}{c}\text { Valor } \\
\mathrm{T} \\
\left(\mathrm{cmolc}^{2} /\right. \\
\left.\mathrm{cm}^{3}\right)\end{array}$ & $\begin{array}{c}\text { Valor } \\
\text { A } \\
\left(\mathrm{cmolc}^{2} /\right. \\
\left.\mathrm{cm}^{3}\right)\end{array}$ & $\begin{array}{c}\text { Valor } \\
\text { V } \\
\left(\mathrm{cmolc}^{2}\right. \\
\left.\mathrm{cm}^{3}\right)\end{array}$ \\
\hline $\begin{array}{l}\text { CTC- } \\
\text { SP-3 }\end{array}$ & 41,4 & 0,1 & 2,7 & 2,1 & 0,9 & 46,8 & 2,8 & 3,3 & 6,1 & $45,9 \%$ & $54,1 \%$ \\
\hline $\begin{array}{l}\text { CTC- } \\
\text { SP-2 }\end{array}$ & 41,4 & 0,1 & 2,7 & 1,8 & 1,1 & 46,8 & 2,8 & 3,2 & 6,0 & $46,7 \%$ & $53,3 \%$ \\
\hline $\begin{array}{l}\text { CTC- } \\
\text { SP-1 }\end{array}$ & 41,4 & 0,1 & 3,5 & 2,0 & 1,2 & 46,8 & 3,6 & 3,5 & 7,1 & $50,9 \%$ & $49,1 \%$ \\
\hline $\begin{array}{l}\text { CTC- } \\
\text { SL1-3 }\end{array}$ & 50,6 & 0,4 & 4,7 & 1,3 & 0,9 & 42,9 & 5,1 & 2,5 & 7,6 & $66,9 \%$ & $33,1 \%$ \\
\hline $\begin{array}{l}\text { CTC- } \\
\text { SL1-2 }\end{array}$ & 50,6 & 0,3 & 4,2 & 1,4 & 1,3 & 46,8 & 4,5 & 3,0 & 7,5 & $59,4 \%$ & $40,6 \%$ \\
\hline $\begin{array}{l}\text { CTC- } \\
\text { SL1-1 }\end{array}$ & 50,6 & 0,3 & 4,3 & 1,3 & 1,0 & 46,8 & 4,6 & 2,6 & 7,3 & $63,6 \%$ & $36,4 \%$ \\
\hline
\end{tabular}




\begin{tabular}{|c|c|c|c|c|c|c|c|c|c|c|c|}
$\begin{array}{c}\text { CTC- } \\
\text { SL5-3 }\end{array}$ & 121,9 & 0,6 & 4,7 & 2,1 & 0,9 & 58,5 & 5,3 & 3,7 & 9,0 & $58,9 \%$ & $41,1 \%$ \\
\hline $\begin{array}{c}\text { CTC- } \\
\text { SL5-2 }\end{array}$ & 121,9 & 0,5 & 4,0 & 1,8 & 1,1 & 58,5 & 4,5 & 3,6 & 8,0 & $55,4 \%$ & $44,6 \%$ \\
\hline $\begin{array}{c}\text { CTC- } \\
\text { SL5-1 }\end{array}$ & 119,6 & 0,6 & 4,2 & 1,9 & 0,9 & 58,5 & 4,8 & 3,5 & 8,3 & $58,0 \%$ & $42,0 \%$ \\
\hline $\begin{array}{c}\text { CTC- } \\
\text { SL10-3 }\end{array}$ & 207,0 & 0,4 & 5,5 & 2,9 & 1,7 & 85,8 & 5,9 & 5,7 & 11,7 & $50,9 \%$ & $49,1 \%$ \\
\hline $\begin{array}{c}\text { CTC- } \\
\text { SL10-2 }\end{array}$ & 207,0 & 0,3 & 4,5 & 2,9 & 1,8 & 85,8 & 4,8 & 5,8 & 10,6 & $45,1 \%$ & $54,9 \%$ \\
\hline $\begin{array}{c}\text { CTC- } \\
\text { SL10-1 }\end{array}$ & 230,0 & 0,4 & 4,9 & 3,5 & 0,9 & 85,8 & 5,3 & 5,6 & 10,9 & $48,4 \%$ & $51,6 \%$ \\
\hline
\end{tabular}

Tabela 34 - Valores em triplicata para o cálculo da capacidade de troca catiônica das amostras de solo com $0 \%, 1 \%, 5 \%$ e $10 \%$ de RPC

A tabela 31 mostra as médias para cada teor de mistura, unificando os valores obtidos em triplicata:

\begin{tabular}{|c|c|c|c|c|c|c|c|c|c|c|c|}
\hline ostra & $\begin{array}{l}\mathrm{Na} \\
(\mathrm{mg} / \\
\left.\mathrm{cm}^{3}\right)\end{array}$ & $\begin{array}{c}\mathrm{Al} \\
\left(\mathrm{cmolc}^{2} /\right. \\
\left.\mathrm{cm}^{3}\right)\end{array}$ & $\begin{array}{c}\mathrm{H}^{+} \\
\left(\mathrm{cmolc}^{2} /\right. \\
\left.\mathrm{cm}^{3}\right)\end{array}$ & $\begin{array}{c}\mathrm{Ca} \\
\left(\mathrm{cmolc}^{2} /\right. \\
\left.\mathrm{cm}^{3}\right)\end{array}$ & $\begin{array}{c}\mathrm{Mg} \\
\left(\mathrm{cmolc}^{2} /\right. \\
\left.\mathrm{cm}^{3}\right)\end{array}$ & $\begin{array}{c}\mathrm{K} \\
(\mathrm{mg} / \\
\left.\mathrm{cm}^{3}\right)\end{array}$ & \begin{tabular}{|c|} 
Acidez \\
Potencial \\
$(\mathrm{cmolc} /$ \\
$\left.\mathrm{cm}^{3}\right)$ \\
\end{tabular} & \begin{tabular}{|c} 
Valor \\
$\mathrm{S}$ \\
$\left(\mathrm{cmolc}^{2} /\right.$ \\
$\left.\mathrm{cm}^{3}\right)$ \\
\end{tabular} & $\begin{array}{c}\text { Valor } \\
\mathrm{T} \\
\left(\mathrm{cmol}^{2} /\right. \\
\left.\mathrm{cm}^{3}\right) \\
\end{array}$ & \begin{tabular}{|c|} 
Valor \\
A \\
$\left(\mathrm{cmolc}^{2}\right.$ \\
$\left.\mathrm{cm}^{3}\right)$ \\
\end{tabular} & $\begin{array}{c}\text { Valor } \\
\text { V } \\
\left(\mathrm{cmolc}^{2} /\right. \\
\left.\mathrm{cm}^{3}\right) \\
\end{array}$ \\
\hline j-SP & 41,4 & 0,1 & 3,0 & 2,0 & 1,1 & 46,8 & 3,1 & 3,3 & 6,4 & $47,9 \%$ & $52,1 \%$ \\
\hline 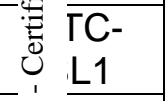 & 50,6 & 0,3 & 4,4 & 1,3 & 1,1 & 45,5 & 4,7 & 2,7 & 7,5 & $54,8 \%$ & $36,7 \%$ \\
\hline 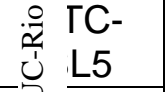 & 121,1 & 0,6 & 4,3 & 1,9 & 1,0 & 58,5 & 4,8 & 3,6 & 8,4 & $59,1 \%$ & $42,6 \%$ \\
\hline $\begin{array}{l}\overline{Q_{-}} \overline{\Gamma C-} \\
\text { SL10 }\end{array}$ & 214,7 & 0,4 & 5,0 & 3,1 & 1,5 & 85,8 & 5,3 & 5,7 & 11,1 & $63,3 \%$ & $51,8 \%$ \\
\hline
\end{tabular}

Tabela 35 - Valores para o cálculo da capacidade de troca catiônica das amostras de solo com $0 \%, 1 \%, 5 \%$ e $10 \%$ de RPC

Para maior clareza na análise, cada coluna da tabela, representativa de uma variável, foi transformada em um gráfico, que inclui também a barra de erro de cada amostra. Assim, têm-se as interpretações a seguir. 


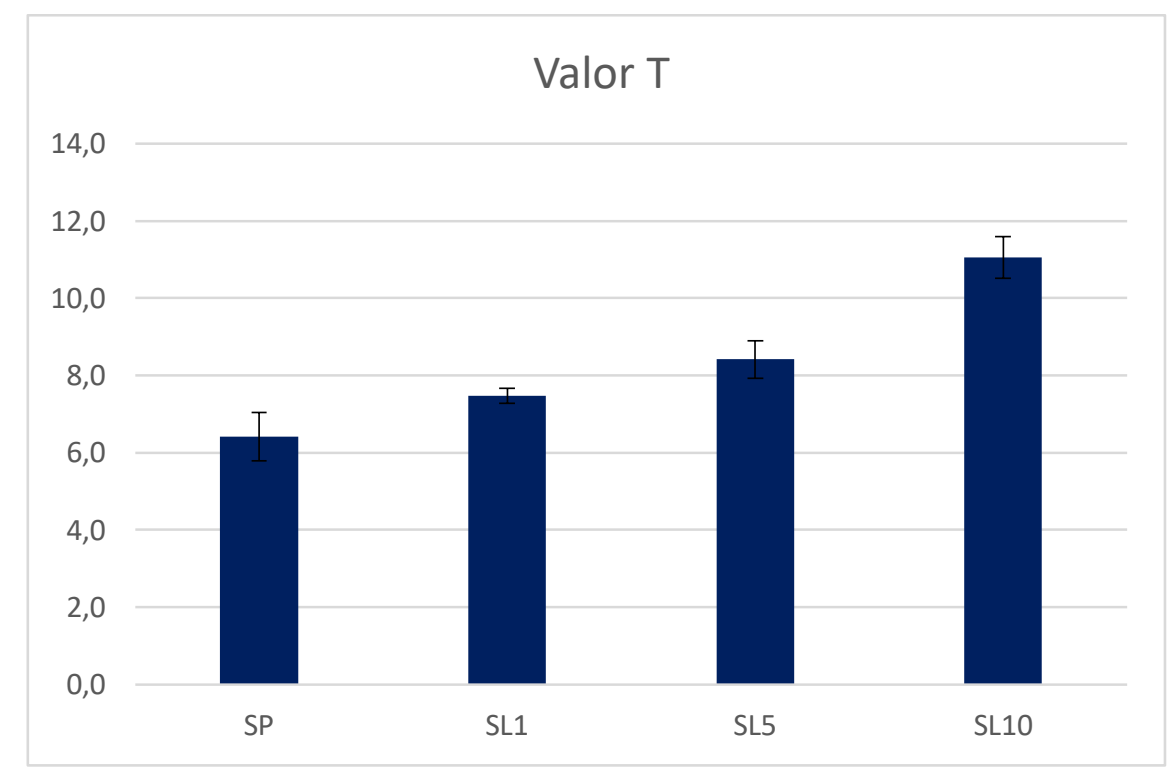

Gráfico 20 - CTC Total a pH 7 em amostras de solo com teores de RPC de $0 \%$, $1 \%, 5 \%$ e $10 \%$

Esse valor é a CTC propriamente dita, exibindo a soma das demais variáveis e dando uma imagem geral da capacidade de troca do solo. Ele aumentou continuamente de acordo com a substituição de parte do solo pelo Resíduo de Produção de Celulose (RPC), o que sugere que este faz a CTC aumentar.

Porém, esse dado por si só não pode ser considerado como um benefício, pois, de acordo com as definições supracitadas, tal valor inclui tanto cátions benéficos à fertilidade, que são $\mathrm{K}, \mathrm{Mg}$ e $\mathrm{Ca}$ (Valor $\mathrm{S}$ ); quanto os prejudiciais, que são $\mathrm{H}^{+}$e $\mathrm{Al}$ (Acidez Potencial). Assim, foi necessária a observação das variáveis isoladamente, conforme os próximos gráficos. 


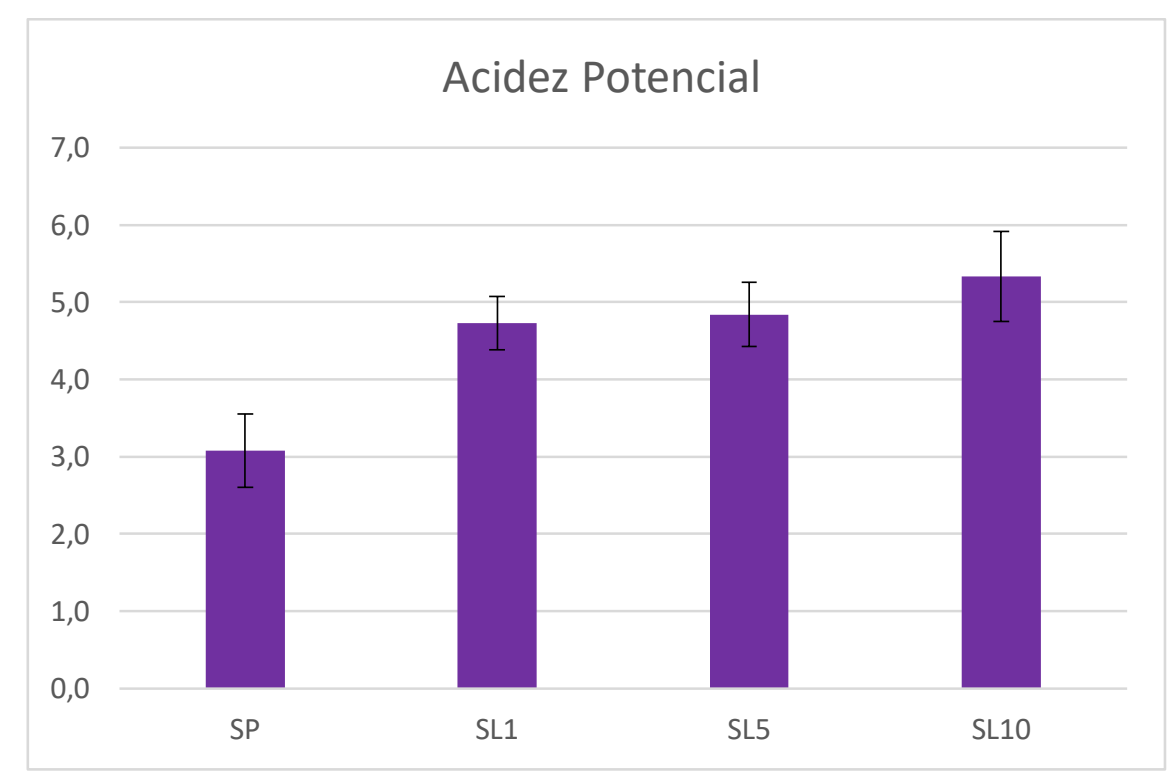

Gráfico 19 - Acidez potencial em amostras de solo com teores de RPC de 0\%, $1 \%, 5 \%$ e $10 \%$

Nesse gráfico, representativo dos cátions prejudiciais à fertilidade, nota-se a clara tendência de aumento de acidez ocasionada pelo acréscimo de RPC. Isso indica que o solo pode não ter sido beneficiado, caso a acidez tenha subido mais que o Valor S. É importante ressaltar, todavia, que a acidez, embora seja prejudicial, pode ser corrigida por meio da calagem do solo. Dessa forma, um valor alto da mesma não constitui um problema que impossibilite o uso do RPC.

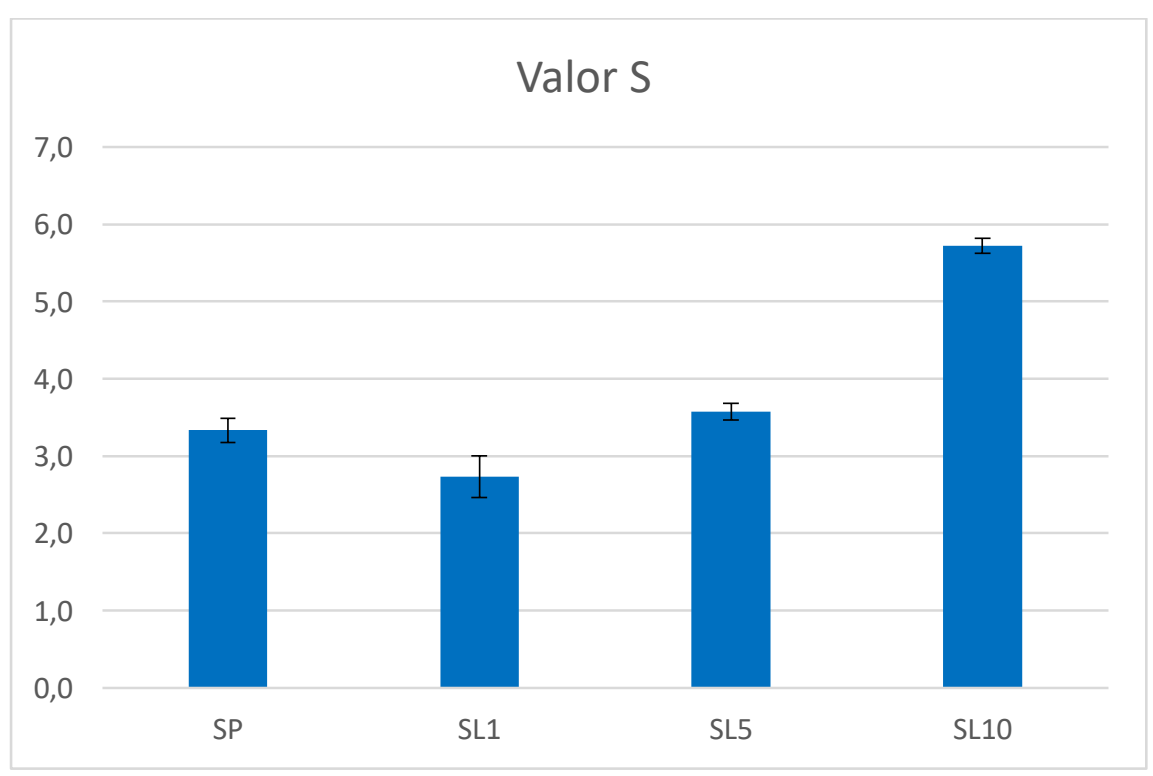


Gráfico 20 - Soma de Bases Trocáveis em amostras de solo com teores de RPC de $0 \%, 1 \%, 5 \%$ e $10 \%$

Tal gráfico exibe apenas a soma dos cátions que beneficiam a fertilidade. Apesar da queda inesperada entre o solo puro e o de $1 \%$, notou-se um contínuo aumento nos teores $5 \%$ e $10 \%$, o que sugere que o RPC beneficiou o solo. No entanto, os valores mostraram-se mais baixos que os da Acidez Potencial, de modo que o resultado geral não foi bom para a fertilidade. Isso fica mais claro ao ver os gráficos 17 e 18, que correlacionam os valores à CTC Total a pH 7 .

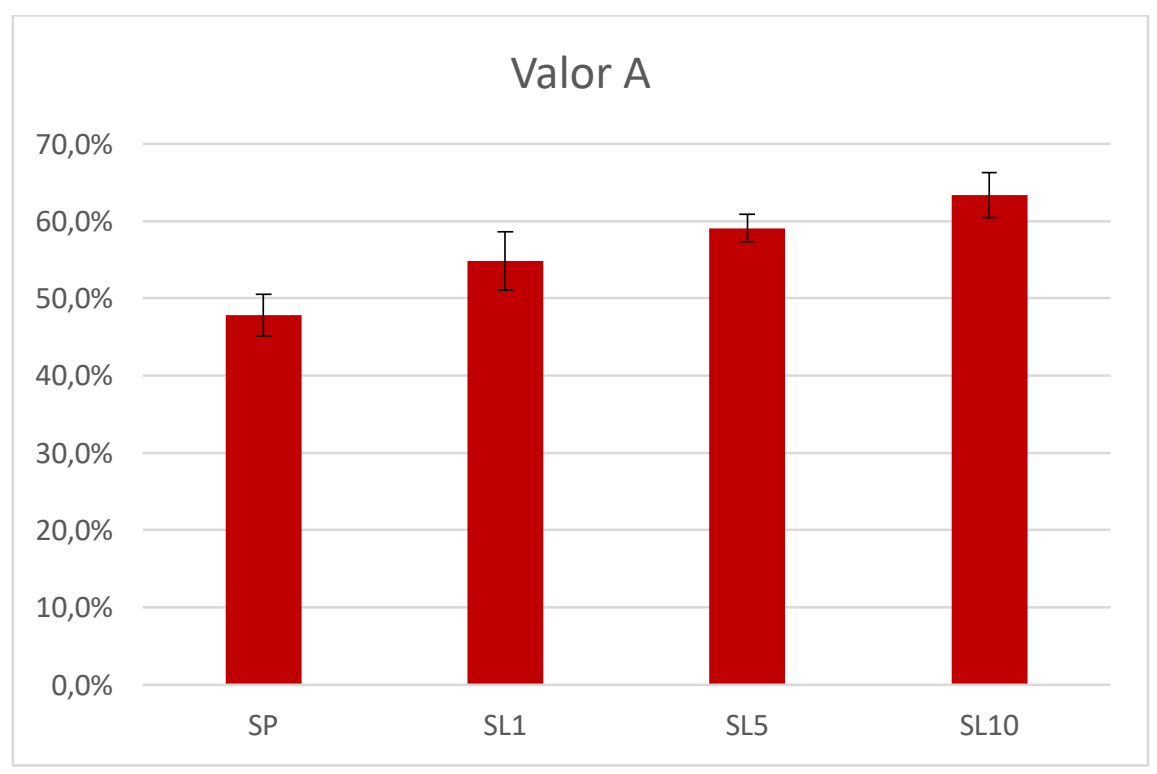

Gráfico 21 - Valor A em amostras de solo com teores de RPC de 0\%, 1\%, 5\% e $10 \%$

Essa variável mostra a relação entre os cátions danosos e o total de cátions. Seu aumento contínuo indica que o solo se tornou mais ácido, o que induz à perda de fertilidade. 


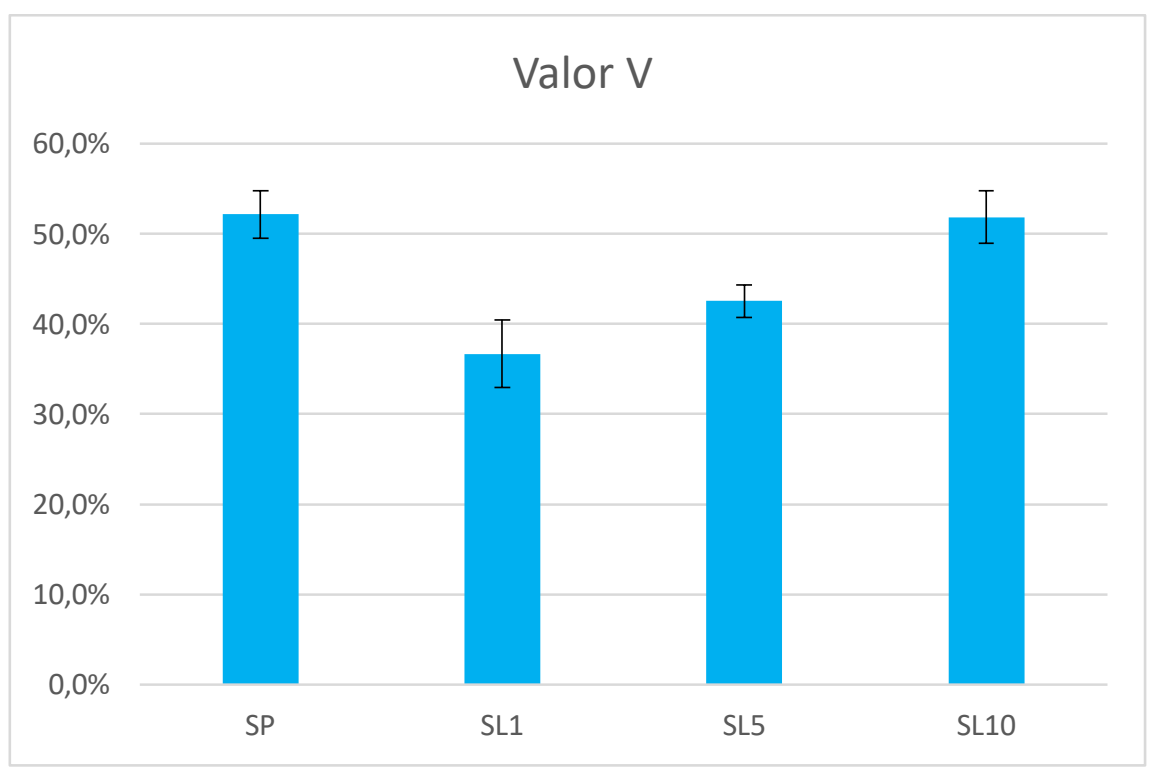

Gráfico 22 - Valor V em amostras de solo com teores de RPC de 0\%, 1\%, 5\% e $10 \%$

Tal variável indica a relação entre os cátions benéficos e o total de cátions. Nesse caso, nota-se que nenhuma das misturas de solo e RPC teve resultado melhor do que o do solo puro. Isso contraria o que o aumento no Valor $S$ sugeriu, pois seria esperado que o valor $V$ também fosse maior nas misturas de $5 \%$ e $10 \%$. Todavia, apesar de o RPC ter aumentado a quantidade de cátions benéficos, ele aumentou ainda mais a dos prejudiciais. Além disso, houve aumento no cátion sódio, conforme o gráfico 19; e este não faz parte nem da Acidez Potencial nem do Valor S, mas faz do Valor T.

Complementando os resultados, têm-se os gráficos de cada cátion isoladamente, na unidade milimol. Além disso, fez-se a tabela 32, mostrando o percentual de cada cátion em relação à soma de todos (para isso, os valores de $\mathrm{Na}$ e $\mathrm{K}$ foram convertidos para milimol, apenas dividindo-se os dados em miligrama pela massa molar de cada um).

\begin{tabular}{|c|c|c|c|c|c|c|}
\hline Amostra & $\% \mathrm{Na}$ & $\% \mathrm{Al}$ & $\% \mathrm{H}+$ & $\% \mathrm{Ca}$ & $\% \mathrm{Mg}$ & $\% \mathrm{~K}$ \\
\hline CTC-SP & $2,8 \%$ & $1,6 \%$ & $46,3 \%$ & $30,8 \%$ & $16,6 \%$ & $1,9 \%$ \\
\hline CTC-SL1 & $2,9 \%$ & $4,5 \%$ & $58,9 \%$ & $17,9 \%$ & $14,3 \%$ & $1,6 \%$ \\
\hline CTC-SL5 & $6,3 \%$ & $6,7 \%$ & $50,7 \%$ & $23,0 \%$ & $11,5 \%$ & $1,8 \%$ \\
\hline CTC-SL10 & $8,5 \%$ & $3,3 \%$ & $44,9 \%$ & $28,1 \%$ & $13,3 \%$ & $2,0 \%$ \\
\hline
\end{tabular}


Tabela 36 - Percentual de cada cátion por amostra

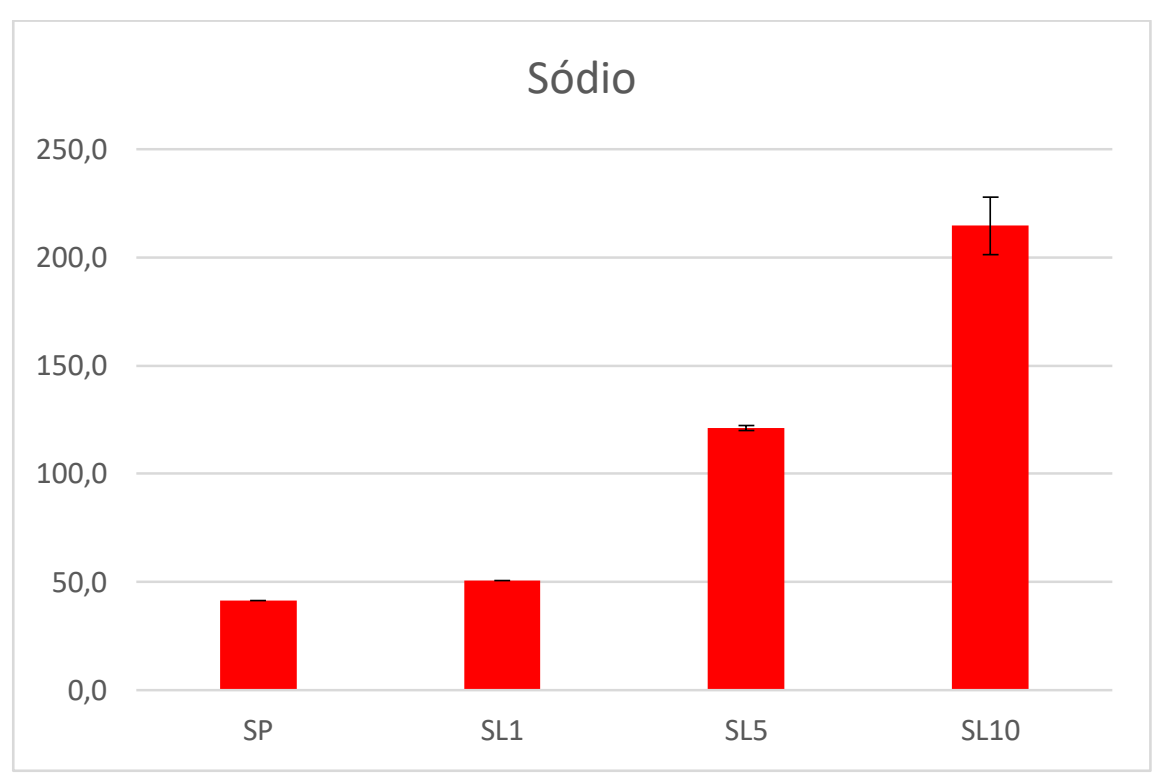

Gráfico 23 - Sódio em amostras de solo com teores de RPC de 0\%, 1\%, 5\% e $10 \%$

Nota-se um claro aumento na capacidade de troca de sódio. Assim, a fração de cátions do Valor S ficou menor, diante do intenso aumento dos cátions de sódio e da Acidez Potencial. O gráfico crescente parece ser devido à presença desse cátion no RPC, sendo isso devido ao uso de hidróxido de sódio no processo de separação da celulose do restante da matéria vegetal. Logo, caso esse reagente seja substituído por outro, como o hidróxido de potássio, seria possível que o aumento ocorresse mais fortemente em outro cátion. 


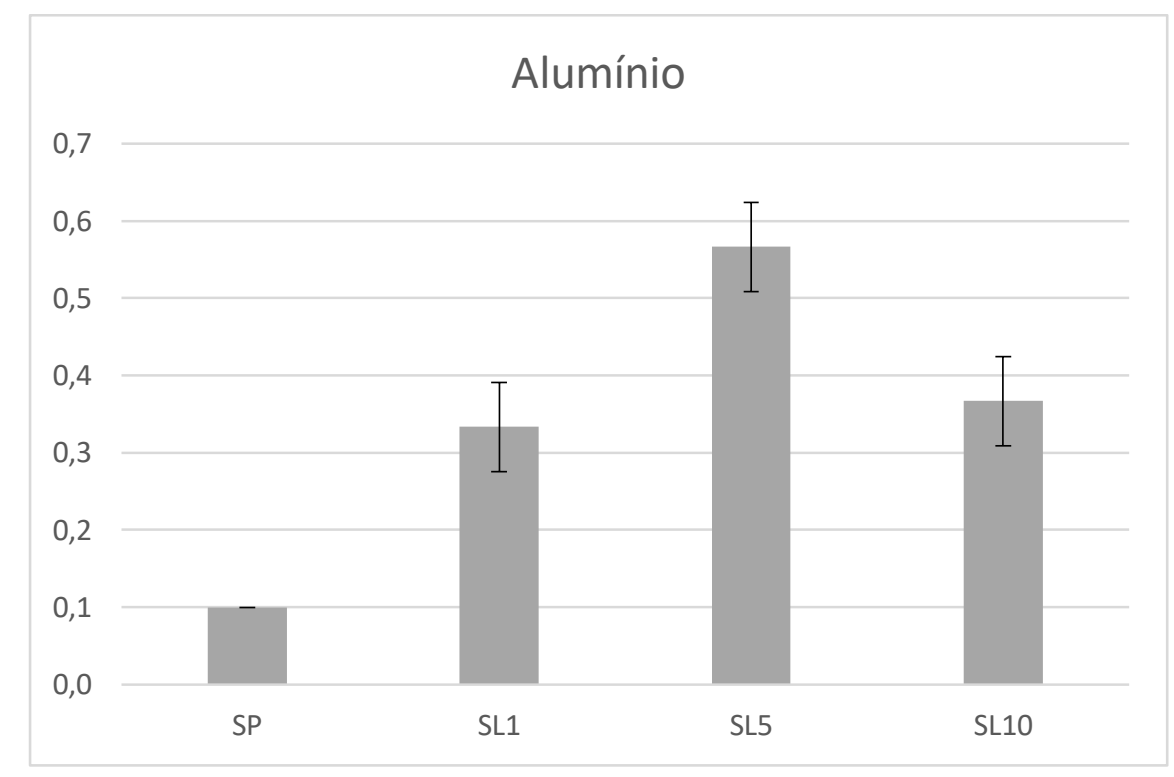

Gráfico 24 - Alumínio em amostras de solo com teores de RPC de 0\%, 1\%, 5\% e $10 \%$

Houve aumento de 0 a $5 \%$ de RPC, e uma queda inesperada em 10\%. Porém, os valores, de uma forma geral, foram os mais baixos dentre todos os cátions, de modo que o maior dano à fertilidade do solo tende a ser não por causa do Alumínio, e sim do Hídron $\left(\mathrm{H}^{+}\right)$. Deve-se dizer, porém, que um pH mais alcalino poderia reduzir esse teor de alumínio, de modo que há solução para o problema.

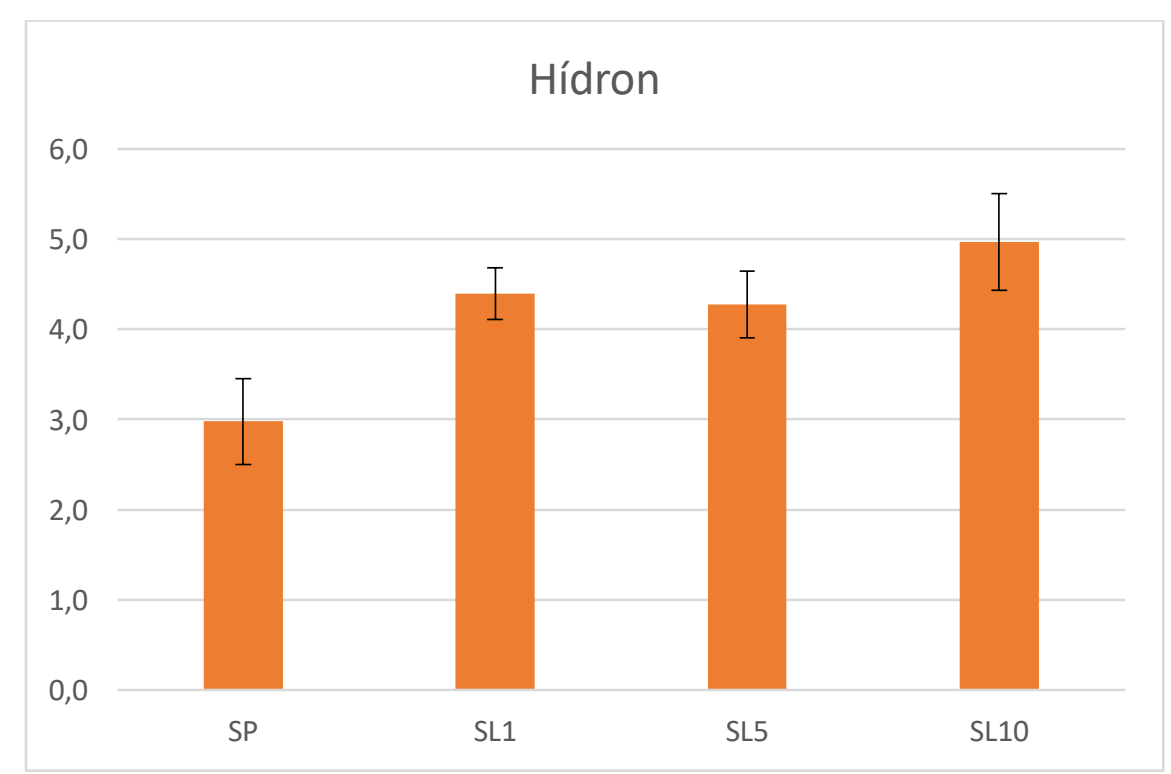


Gráfico 25 - Hídron em amostras de solo com teores de RPC de 0\%, 1\%, 5\% e $10 \%$

Tendência de aumento, apesar de irregular. A tabela, por sua vez, mostrou que a capacidade de troca do solo para esse cátion é a maior de todas, o que indica prejuízo para a fertilidade. Então, poderia ser útil a calagem.

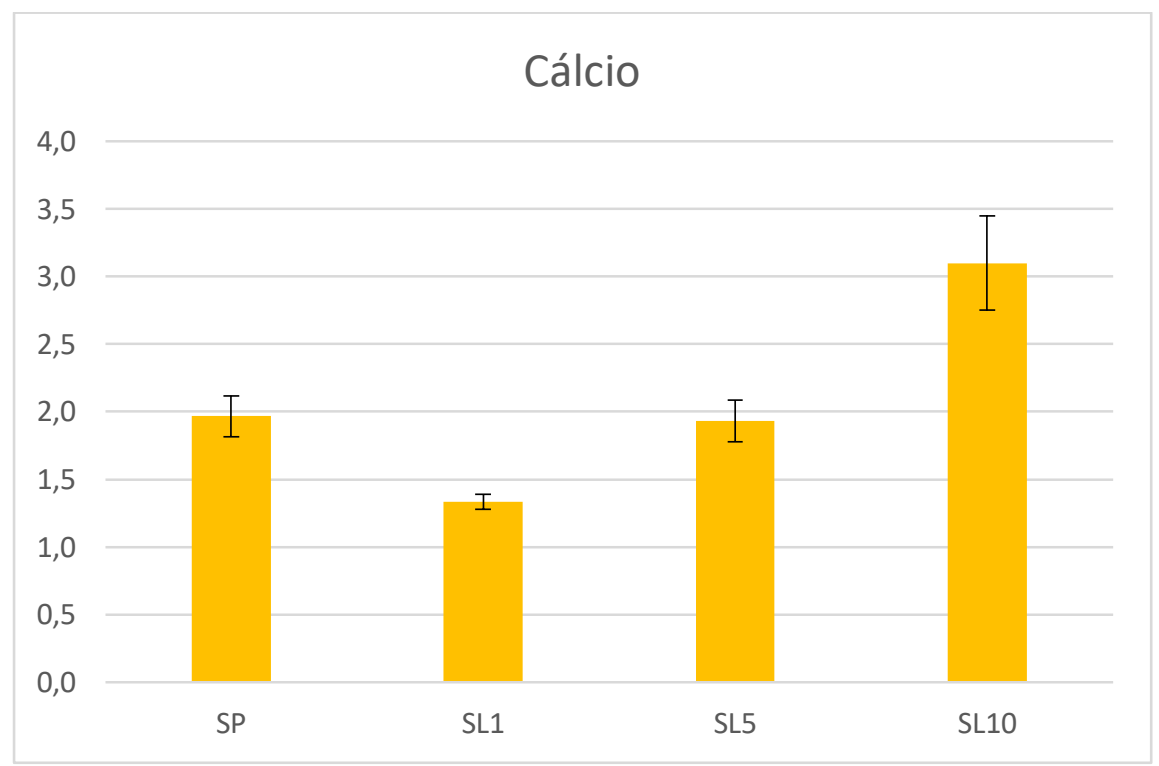

Gráfico 26 - Cálcio em amostras de solo com teores de RPC de 0\%, 1\%, 5\% e $10 \%$

Tal cátion teve uma queda inesperada, seguida, porém, por crescimentos. Configura-se um ganho de fertilidade, ainda que tenha sido sobreposto pela perda ocasionada por outros cátions. 


\section{Magnésio}

2,5

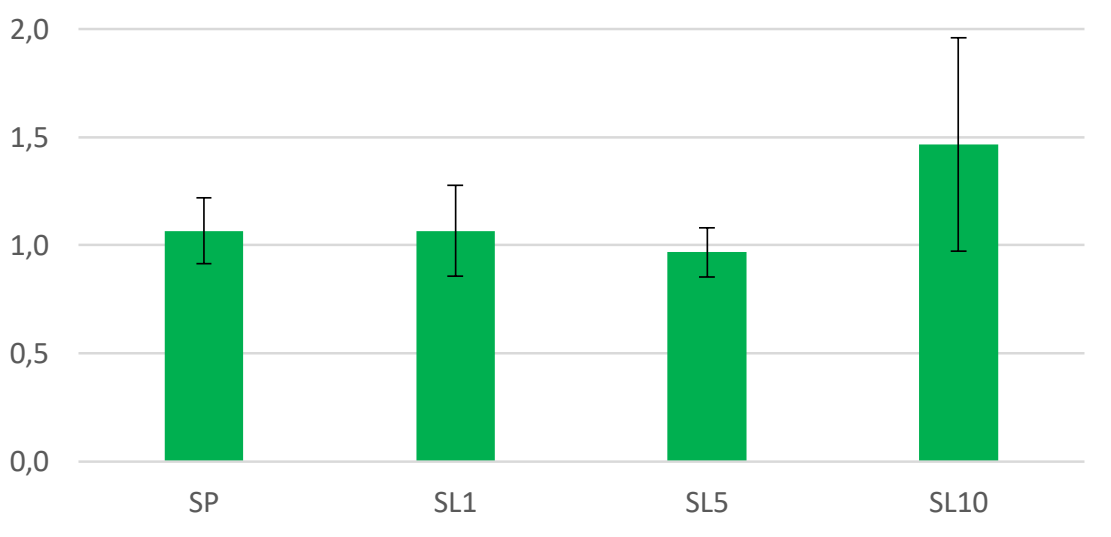

Gráfico 27 - Magnésio em amostras de solo com teores de RPC de 0\%, 1\%, 5\% e $10 \%$

Esse íon variou pouco, se observada a pequena quantidade dos 4 valores. Houve pequena queda, seguida de aumento. Porém, não pareceu ter alterações muito vistosas.

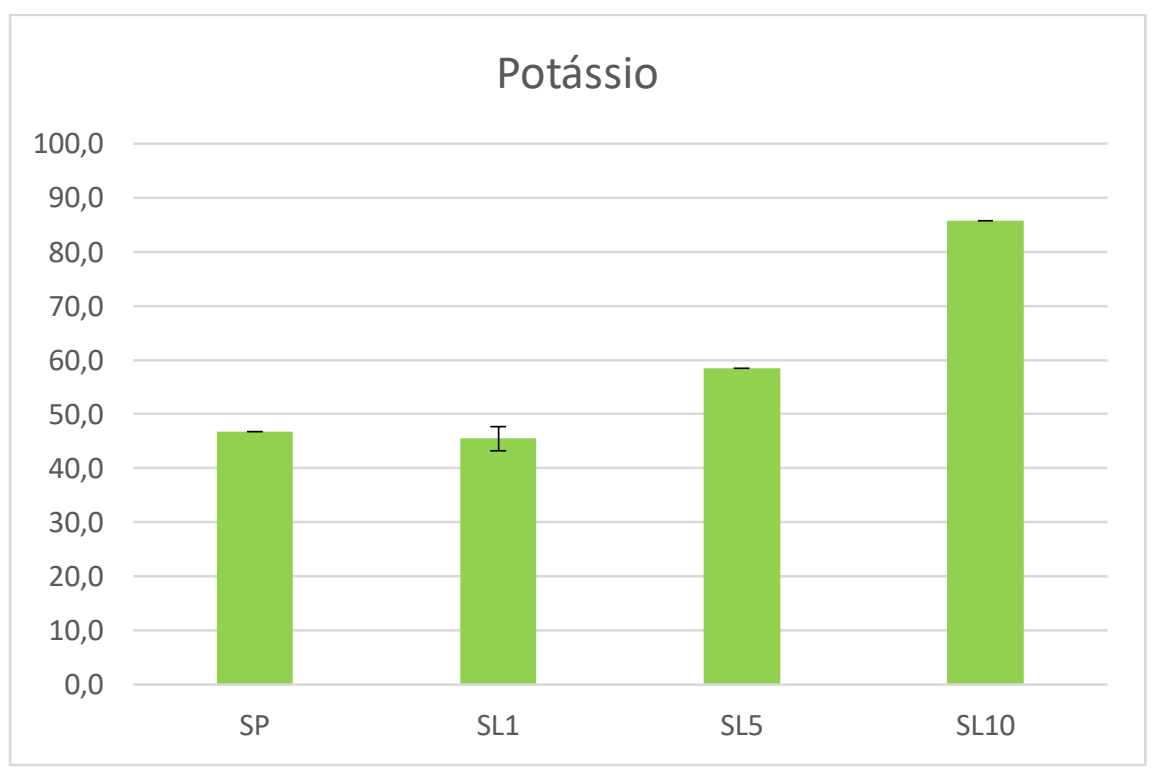

Gráfico 28 - Potássio em amostras de solo com teores de RPC de 0\%, 1\%, 5\% e $10 \%$ 
Tal cátion, apesar da pequena queda entre 0 e 1\% de RPC, teve notável incremento em $5 \%$ e $10 \%$. Assim, nota-se uma tendência de elevação da fertilidade.

Diante do conjunto dos resultados, a capacidade do solo de trocar cátions parece ser intensificada pela substituição de parte de sua massa por massa de RPC. Porém, tal elevação foi maior nos cátions que lhe conferem acidez, que são o alumínio e o hídron, e no sódio; enquanto os cátions favoráveis à fertilidade, que são cálcio, magnésio e potássio tiveram aumento menos expressivo. Apesar disso, pode-se considerar que o RPC é promissor como favorecedor da fertilidade, visto que a acidez do solo pode ser corrigida por outros aditivos, como o calcário. Nesse caso, os ganhos nos cátions benéficos poderiam sobressair, de modo que o RPC eleve a fertilidade do solo. Além disso, a indicação de que o sódio do RPC pode ter sido liberado no solo sugere que o uso de reações químicas diferentes na indústria de celulose pode ser útil, caso produza um RPC que tenha outra composição e, consequentemente, eleve outro cátion no solo, como o potássio, beneficiando-o mais. 


\section{6.}

\section{Conclusão}

O fluxo de trabalho descrito por esta dissertação possibilitou variadas conclusões, apresentadas a seguir.

Primeiramente, é válido comentar sobre a obtenção de um composto rico em lignina a partir do bagaço de cana-de-açúcar, por meio do processo Klason. Tal mecanismo pareceu criar um produto com predomínio composicional exercido pela lignina, tendo isso sido corroborado pelo termograma obtido. Todavia, o baixo rendimento do processo tornou-o inadequado à continuidade da pesquisa, de modo que outro resíduo com lignina foi o adotado para os procedimentos subsequentes.

Explicitando a natureza desse resíduo, deve-se dizer que foi adotado o pó originário do licor de negro de uma fábrica de celulose. De acordo com a termogravimetria, esse resíduo contém celulose, hemicelulose, lignina e cinzas em teores similares entre si, sendo adequado aos testes pretendidos.

A etapa de funcionalização do resíduo por ácido mostrou que o ácido nítrico teve rendimento de massa remanescente muito baixo, enquanto 0 fosfórico teve razoável e o acético teve um rendimento alto, parecendo ser o mais apropriado.

Ainda comparando os 3 métodos de funcionalização, tem-se que, de acordo com a microscopia, o ácido acético foi mais eficaz na criação de poros no material, além de elevar a rugosidade. Esses 2 fatores incrementam a relação superfície-volume do sólido, favorecendo os mecanismos de adsorção que dele se esperam. O composto resultante do processo Klason, por sua vez, também exibiu notável rugosidade, apresentando-se como candidato a adsorvente para uso no condicionamento de solos. Além desses, o resíduo não funcionalizado também exibiu notáveis rugosidade e superfície de contato.

A análise por EDS mostrou que a funcionalização por ácido fosfórico não trouxe oxidação muito intensa, enquanto a do acético resultou em intensidade moderada e a do nítrico teve a mais alta. Contudo, considerando que o ácido acético foi mais eficaz no aumento da porosidade e forneceu um rendimento 
gravimétrico melhor, ele pareceu ser o melhor método para a funcionalização da biomassa.

De acordo com a Espectroscopia no infravermelho por transformada de Fourier (FTIR) , tanto o resíduo antes da funcionalização quanto o funcionalizado apresentaram grupos funcionais oxigenados, o que indica possível atuação na adsorção de água e sais. Dessa forma, o uso do resíduo original no solo mostrou-se a opção mais eficiente, por evitar desperdício na massa de resíduo aplicada.

A aplicação do resíduo no solo, na qual consistiu o manejo final do material, não afetou de forma relevante o limite de plasticidade. $O$ limite de liquidez, diferentemente, teve um perceptível aumento, o que sugere que, em comparação com o solo puro, o conjunto adquiriu maior capacidade de reter água sem fluir com a ação de uma enxurrada. Com isso, parece ter ocorrido aumento tanto na capacidade de retenção de água, que facilita o fornecimento da mesma para vegetais e demais seres; quanto na retenção do próprio solo diante da ação erosiva da água, visto que o líquido é assimilado em vez de causar escoamento do solo.

Além da fixação de água e do próprio solo, o uso do resíduo pareceu favorecer a adsorção de sais nutrientes. Nesse caso, os nutrientes em que houve notável aumento na capacidade de troca foram cálcio e potássio. Por outro lado, houve elevação também na acidez causada pelo cátion hídron, e essa modificação foi mais intensa que a dos íons supracitados. Assim, seria necessária a neutralização do $\mathrm{pH}$ do solo, com calagem ou técnica equivalente, para que o ganho de fertilidade ocasionado pelo cálcio e pelo potássio predomine.

É válido ressaltar, ainda, que a aplicação do resíduo no solo, em detrimento de uma queima, fixa o carbono na forma sólida, evitando o excesso de gases com tal elemento na atmosfera e os consequentes problemas de intensificação do efeito estufa e acidificação dos oceanos.

Parece ser possível dizer, portanto, que a aplicação do resíduo de produção de celulose, obtido a partir do licor negro, sobre o solo é benéfica porque, além de dar um novo uso ao resíduo, eleva a retenção de água, de sais nutrientes, de carbono e do próprio solo em local e forma mais adequados à qualidade ambiental. Logo, seu uso é incentivado para pesquisas futuras. 


\section{7.}

\section{Recomendações}

Dado que o uso no solo dos compostos ricos em lignina desta pesquisa ainda não foi muito estudado, o presente trabalho pode ser encarado como um ponto de partida nesse tema. Assim, faz-se importante deixar recomendações para trabalhos futuros, a fim de ampliar o conhecimento sobre 0 assunto e propiciar atividades de aplicação em larga escala.

Uma das sugestões é otimizar a obtenção de lignina a partir do bagaço de cana-de-açúcar, de modo que uma maior massa de composto seja obtida a cada execução do procedimento.

Outra otimização a ser feita em pesquisas vindouras é do processo de ativação dos resíduos de produção de celulose, de modo que o rendimento mássico seja aumentado. Isso deve ser feito especialmente no caso do ácido acético, dado que ele pareceu o mais promissor.

Uma vez que a obtenção de material funcionalizado esteja mais fácil, seria interessante fazer os testes de Limites de Atterberg e de Capacidade de Troca Catiônica com o resíduo funcionalizado por ácido acético, comparando-se os resultados aos deste trabalho.

Além disso, poderia ser útil comparar a aplicação de RPC sobre solos com diferentes granulometrias, observando-se as diferenças entre areia, argila e demais tipos.

Poder-se-ia analisar, ainda, a degradação do RPC no solo, observando-se a liberação de $\mathrm{CO}_{2}$ ao longo do tempo e o desaparecimento da massa do resíduo. Isso seria importante para analisar a função do material como condicionador, pois uma grande durabilidade do mesmo no solo seria necessária para que os efeitos permaneçam por muito tempo.

Por fim, seria interessante testar o plantio de sementes no solo acrescido de material rico em lignina, a fim de observar se os vegetais crescem mais rapidamente. Nesse estudo, recomenda-se detalhado monitoramento e testes de correção do $\mathrm{pH}$ do solo, dado que o resíduo testado neste trabalho pareceu estimular a acidez do conjunto. 
Somando-se as conclusões deste trabalho a esses passos recomendados, espera-se que seja criado um bom mecanismo de favorecimento do meio ambiente por meio da aplicação sobre o solo de compostos ricos em lignina. 


\section{8.}

\section{Referências bibliográficas}

ARGYROPOULOS, D.S., MENACHEM, S.B.. In:_Kaplan, D.L. (Ed.), Biopolymers from Renewable Resources. Springer, Berlin, 1998. p. 292.

BADHAN, A.K.; CHADHA, B.S.; KAUR, Jatinder, SAINI, H.S.; BHAT, M.K.. Production of multiple xylanolytic and cellulolytic enzymes by thermophilic fungus Myceliophthora sp. IMI 387099. Bioresource Technology, v. 98, Issue 3. Elsevier, February 2007. p. 504-510.

BHATNAGAR, Amit; SILLANPÄÄ, Mika. Utilization of agro-industrial and municipal waste materials as potential adsorbents for water treatment-A review. Chemical Engineering Journal, v. 157, Issues 2-3. Elsevier, Março 2010. p. 277-296.

BERTONI, José; LOMBARDI NETO, Francisco. Conservação do solo. 7. ed. São Paulo: Ícone, 2010. 355 p. (Coleção Brasil agrícola). ISBN 9788527409803

BRADY, Nyle C.; Weil, Ray R.; tradução técnica: Igo Fernando Lepsch. Elementos da natureza e propriedades dos solos. 3. ed.. Porto Alegre: Bookman, 2013. 686 p. ISBN 978-85-65837-74-3

BURANOV, Anvar U.; MAZZA, G.. Lignin in straw of herbaceous crops. Industrial Crops and Products. Summerland, BC, VOH 1 ZO Canada: Elsevier, Novembro 2008. p. 238-259.

CARVALHO, João Luis Nunes et al. Potencial de sequestro de carbono em diferentes biomas do Brasil. Rev. Bras. Ciênc. Solo, Viçosa, v. 34, n. 2, p. $277-$ 290, Abril de 2010. Disponível em <http://www.scielo.br/scielo.php?script =sci_arttext\&pid=S0100-06832010000200001\&lng=en\&nrm=iso >. Acessado em 22 Março 2017.

CHEN, C-L. .Lignin: Occurrence in woody tissues, isolation, reactions, and structure. In:__ Wood Structure and Composition, M. Lewin and I.S. Goldstein (Ed.). New York Marcel Oekker, 1991. p. 183-261.

DICK, Deborah P.; DA COSTA, Janaina B.; LEITE, Anderson José B., BROCCHI, Eduardo A.. Impact of HNO3 Solution Treatment of South Brazil Coal Matrices on Their Chemical Composition and Humic Acids Yield. J. 
Braz. Chem. Soc., Vol. 00, No. 00. Brasil: Sociedade Brasileira de Química, 2016. p. 1-10.

DONAGEMMA, Guilherme Kangussú; CAMPOS, David Vilas Boas de; CALDERANO, Sebastião Barreiros; TEIXEIRA, Wenceslau Geraldes; VIANA, Joao Herbert Moreira (Organizadores). Manual de Métodos de Análise de Solo. 2. ed. revista. Rio de Janeiro: Embrapa Solos, 2011. 230 p.: il. (Embrapa Solos. Documentos, 132). ISSN 1517-2627

DOUMER, Marta Eliane; ABATE, Gilberto; MESSERSCHMIDT, lara; ASSIS, Lívia Mari; MARTINAZZO, Rosane; SILVEIRA, Carlos Augusto Posser. Efeito da ativação química nas propriedades de superfície de xisto retortado. Quím. Nova, v. 39, n. 4, São Paulo: Sociedade Brasileira de Química, maio de 2016. p. 431-436. Disponível em <http://www.scielo.br/scielo.php?script=sci_arttext\&p $\mathrm{id}=\mathrm{S} 0100-40422016000400431 \& \operatorname{lng}=e n \& \mathrm{nrm}=\mathrm{iso}>$. Acessado em 29 Mar. 2017. http://dx.doi.org/10.5935/0100-4042.20160051. ISSN 1678-7064

FAO e ITPS. Status of the World's Soil Resources (SWSR) - Main Report. Food and Agriculture Organization of the United Nations and Intergovernmental Technical Panel on Soils, Roma, Itália, 2015. ISBN 978-92-5-109004-6

FENGEL, D.; WEGENER, G.. Wood-chemistry, ultrastructure, reactions. Walter de Gruyter, Berlim e Nova York, 1984. 613 p.

FERREIRA, Aurélio Buarque de Holanda; coordenação de edição, Margarida dos Anjos, Marina Baird Ferreira; lexicografia, Margarida dos Anjos... [et al.]. Miniaurélio Século XXI Escolar: 0 minidicionário da língua portuguesa. 4. ed. rev. ampliada. Rio de Janeiro: Nova Fronteira, 2001. 790 p. ISBN 85-209$1114-5$

FIGUEIRA, Tiphane Andrade. Avaliação sobre o potencial de extração de ácidos húmicos a partir de diferentes precursores carbonáceos. Orientador: Eduardo de Albuquerque Brocchi. Dissertação de Mestrado. Departamento de Engenharia de Materiais, Pontifícia Universidade Católica do Rio de Janeiro, Rio de Janeiro, 2014. $125 \mathrm{f}$.

FRAGOSO, Carlos Leonny Raimundo. Caracterização de apatitas por análise de infravermelho. Orientador: Adriano Alves Passos. Trabalho de Conclusão de Curso. Graduação em Química, Fundação Técnico-Educacional Souza Marques, Rio de Janeiro, 2013. $61 \mathrm{f}$. 
GLASER, Bruno; BIRK, Jago Jonathan. State of the scientific knowledge on properties and genesis of Anthropogenic Dark Earths in Central Amazonia (terra preta de Índio). Geochimica et Cosmochimica, Acta 82. Elsevier, 2012, p. 39-51. Disponível em http://www.sciencedirect.com/science /article/pii/S001670371100144X. Acessado em 01 Agosto 2017.

GONÇALVES, Flávia de Miranda. Caracterização de biocarvões e suas capacidades de retenção de nutrientes. Orientador: Francisco José Moura. Dissertação de Mestrado. Departamento de Engenharia de Materiais, Pontifícia Universidade Católica do Rio de Janeiro, Rio de Janeiro, 2016. 86 f.

GUERRA, Antonio José Teixeira; SILVA, Antonio Soares da; BOTELHO, Rosangela Garrido Machado (Org.). Erosão e conservação dos solos: conceitos, temas e aplicações. 5. ed. Rio de Janeiro: Bertrand Brasil, 2010. 339 p. ISBN 9788528607383

HENDRIKS, A.T.W.M.; ZEEMAN, G.. Pretreatments to enhance the digestibility of lignocellulosic biomass. Bioresource Technology, Volume 100, Issue 3. Wageningen, The Netherlands: Elsevier, 2009. p. 10-18.

IPCC, 2001: Climate Change 2001: Synthesis Report. A Contribution of Working Groups I, II, and III to the Third Assessment Report of the Intergovernmental Panel on Climate Change [Watson, R.T. and the Core Writing Team (eds.)]. Cambridge University Press, Cambridge, United Kingdom, and New York, NY, USA, 2001. 398 p. ISBN 0521807700 (hardback) or ISBN 0521015073 (paperback)

IPCC, 2014: Climate Change 2014: Synthesis Report. Contribution of Working Groups I, II and III to the Fifth Assessment Report of the Intergovernmental Panel on Climate Change [Core Writing Team, R.K. Pachauri and L.A. Meyer (eds.)]. IPCC, Geneva, Switzerland, 2015. 151 p. ISBN 9789291691432

LAUREANO-PEREZ, L., TEYMOURI, F., ALIZADEH, H., DALE, B.E.. Understanding factors that limit enzymatic hydrolysis of biomass. Appl. Biochem. Biotechnol., 2005. 1081-1099.

LEITE, Anderson José Barcellos. Ácidos húmicos de carvões do sul do Brasil: obtenção e composição química. 2013. 56 f. Dissertação de Mestrado. Programa de Pós-Graduação em Química, Instituto de Química, Universidade Federal do Rio Grande do Sul, Porto Alegre, 2013. 
LEPSCH, Igo F. Formação e Conservação dos Solos. São Paulo: Oficina de textos, 2002. $178 \mathrm{p}$.

LEWIS, Norman G., YAMAMOTO, Etsuo. Lignin: occurrence, biogenesis and biodegradation. Annu. Rev. Plant Physiol. Plant Mol. Biol. Departments of Wood Science and Biochemistry, Virginia Polytechnic Institute and State University, Blacksburg, Virginia, 1990. 41:455-496.

LINS, Juliana. Terra Preta de Índio: uma lição dos povos pré-colombianos da Amazônia. Revista Agriculturas. v. 12. n. 1. 2015. p. 37-41.

MADARI, Beáta Emöke; PETTER, Fabiano André; CARVALHO, Márcia Thaís de Melo; MACHADO, Diogo Milhomem; SILVA, Orlai Moreira da; FREITAS, Fernando Cunha; OTONI, Rafael de Faria. Biomassa Carbonizada como Condicionante de Solo para a Cultura do Arroz de Terras Altas, em Solo Arenoso, no Cerrado: Efeito Imediato para a Fertilidade do Solo e Produtividade das Plantas. Comunicado Técnico. n. 197. Embrapa. Santo Antônio de Goiás-GO. Dezembro 2010. ISSN 1678-961X

MAFRA, Neusa Maria Costa. Erosão e Planificação de Uso de Uso do Solo. In:___ Erosão e conservação dos solos: conceitos, temas e aplicações. 5. ed. Rio de Janeiro: Bertrand Brasil, 2010. 339 p. ISBN 9788528607383

MANGRICH, Antonio S.; LOBO, Maria A.; TANCK, Carlos B.; WYPYCH, Fernando; TOLEDO, Edina B. S.; GUIMARÃES, Elisete. Criterious Preparation and Characterization of Earthworm-composts in View of Animal Waste Recycling. Part I. Correlation Between Chemical, Thermal and FTIR Spectroscopic Analyses of Four Humic Acids from Earthworm-composted Animal Manure. Jornal da Sociedade Brasileira de Química, v. 11, n. 2. Sociedade Brasileira de Química, Brasil, 2000. p. 164-169.

MCCREERY, R. L.; BERGREN, A. J.. Surface Functionalization in the Nanoscale Domain. In:__ Nanofabrication: Techniques and Principles. New York: Springer-Verlag/Wien, 2012. p 163-190. ISBN 9783709104248

MEZINE, Wesley Andersen; SOARES, Marcos Alberto; FAGGION, Pedro Luis; VEIGA, Luís Augusto Koenig; NADAL, Carlos Aurelio. Avaliação de métodos de redução de sondagens batimétricas ao nível d'água instantâneo para monitoramento de assoreamento: estudo de caso do reservatório da Usina Hidrelétrica Mauá. Boletim de Ciências Geodésicas, v. 22, n. 4. Curitiba, 2016. ISSN 1982-2170 
MINISTÉRIO DA AGRICULTURA, PECUÁRIA E ABASTECIMENTO. SECRETARIA DE DEFESA AGROPECUÁRIA. Instrução Normativa № $\mathbf{3 5}$, de 4 de julho de 2006. Brasil, 2006. 9p.

MIRANDA, Neyton de Oliveira; PIMENTA, Alexandre Santos; SILVA, Gualter Guenther Costa da; OLIVEIRA, Ermelinda Maria Mota; CARVALHO, Mary Anne Barbosa de. Biochar as soil conditioner in the succession of upland rice and cowpea fertilized with nitrogen. Revista Caatinga, v. 30, n. 2. Mossoró. Junho 2017. p. 313-323. Disponível em <http:// www.scielo.br/scielo.php?script=sci_arttext\&pid=S1983-21252017000200313\&ln $\mathrm{g}=$ en\&nrm=iso $>$. Acessado em 10 Setembro 2017.

MORGAN, R. P. C.; KIRKBY, M. J.. Erosión de Suelos. México, Editorial Limusa S. A., 1984.

NAVARRO, Claudia Ines Telleria. Caracterização Microestrutural das Fibras Naturais: Etlingera elatior, Costus e Helicônia bihai. Orientadores: Sidnei Paciornik; José Roberto D’Almeida. Dissertação de Mestrado. Departamento de Engenharia de Materiais, Pontifícia Universidade Católica do Rio de Janeiro, Rio de Janeiro, 2011. $76 \mathrm{f}$.

NIMZ, Horst. Beech Lignin-Proposal of a Constitutional Scheme. Angewandte Chemie International Edition / Vol. 13 / No. 5. 1974. p. 313-321

PINTO, Carlos de Sousa. Curso básico de mecânica dos solos: em 16 aulas. 3. ed. com exercícios resolvidos em 16 aulas. São Paulo: Oficina de textos, 2006. 367 p. ISBN 8586238511

RAIJ, B. van; CANTARELlA, H.; QUAGGIO, J. A.; FURLANI, A. M. C. Recomendações de adubação e calagem para o Estado de São Paulo. 2. ed. Campinas: Instituto Agronômico de Campinas, 1996. 285 p. (IAC. Boletim Técnico, 100).

RONQUIM, Carlos Cesar. Conceitos de fertilidade do solo e manejo adequado para as regiões tropicais. - Campinas: Embrapa Monitoramento por Satélite, 2010. 26 p.: il. (Embrapa Monitoramento por Satélite. Boletim de Pesquisa e Desenvolvimento, 8). ISSN 1806-3322

SAHA, B.C.. Hemicellulose bioconversion. J. Ind. Microbiol. Biotechnol. 30, 2003. p 279-291. 
SANTOS, Nielson Machado dos; ACCIOLY, Adriana Maria de Aguiar; NASCIMENTO, Clistenes Williams Araujo do; SILVA, Ivo Ribeiro; SANTOS, Jorge Antonio Gonzaga. Biodisponibilidade de chumbo por extratores químicos em solo tratado com ácidos húmicos e carvão ativado. Revista Ciência Agronômica, v. 46, n. 4. Centro de Ciências Agrárias, Universidade Federal do Ceará, Fortaleza-CE. Outubro-Dezembro 2015. p. 663-668. ISSN 0045-6888

SANTOS, Paulo R., FÁBREGA, Francine M., D'ANGELO, José Vicente H.. Análisis Termodinámico de un Sistema de Cogeneración con Gasificación del Licor Negro. Información Tecnológica, v. 19, n. 4. Departamento de Engenharia de Sistemas Químicos, Faculdade de Engenharia Química, Universidade Estadual de Campinas - UNICAMP, Campinas-SP, 2008. p. 47-56.

SILVA, R.; HARAGUCHI, S. K.; MUNIZ, E. C.; RUBIRA, A. F.; Aplicações de fibras lignocelulósicas na química de polímeros e em compósitos. In:

Química Nova. v. 32, n. 3. Maringá-PR: Sociedade Brasileira de Química, 2009. p. 661-671.

TROMPOWSKY, Patrick Marques; BENITES; Vinicius de Melo; MADARI, Beata Emoke; PIMENTA, Alexandre Santos; HOCKADAY, William C.; HATCHER, Patrick G.. Characterization of humic like substances obtained by chemical oxidation of eucalyptus charcoal. Organic Geochemistry, Volume 36, Issue 11. Elsevier. Novembro 2005. p. 1480-1489 Disponível em http://www.sciencedirect .com/science/article/pii/S0146638005001 725, acessado em 06 Set. 2017.

WOODS, W.I. Comments on the black earths of Amazonia. Papers and Proceedings of the Applied Geography Conferences. 18. 1995. p. 159-165. 


\section{9.}

\section{Apêndice - Plano de amostras}

Para a adequada nomenclatura de cada amostra a ser usada nos ensaios, adotaram-se as seguintes siglas:

\begin{tabular}{|c|c|}
\hline \multicolumn{2}{|c|}{ Ensaio } \\
\hline CTC & Capacidade de Troca Catiônica \\
\hline LA & Limites de Atterberg (Plasticidade e Liquidez) \\
\hline \multicolumn{2}{|c|}{ Mistura } \\
\hline SP & Solo Puro \\
\hline SCn & Solo com composto no teor de $\mathrm{n} \%$ \\
\hline
\end{tabular}

Tabela 37 - Siglas do plano de amostras

Os ensaios de CTC foram feitos em triplicata, de modo que o número da iteração, variando de 1 a 3, foi incluído no fim do nome. Cada ensaio de CTC demandou $100 \mathrm{~g}$ de amostra, enquanto cada um de LA precisou de $200 \mathrm{~g}$.

Diante dessas premissas, os nomes e quantidades das amostras foram os seguintes:

\begin{tabular}{|r|l|l|l|r|r|r|r|r|}
\hline № & Amostra & Ensaio & Mistura & Iteração & Teor (\%) & Total (g) & Solo (g) & Composto (g) \\
\hline 1 & CTC-SP-1 & CTC & SP & 1 & $0 \%$ & 100 & 100 & 0 \\
\hline 2 & CTC-SP-2 & CTC & SP & 2 & $0 \%$ & 100 & 100 & 0 \\
\hline 3 & CTC-SP-3 & CTC & SP & 3 & $0 \%$ & 100 & 100 & 0 \\
\hline 4 & CTC-SC1-1 & CTC & SC1 & 1 & $1 \%$ & 100 & 99 & 1 \\
\hline 5 & CTC-SC1-2 & CTC & SC1 & 2 & $1 \%$ & 100 & 99 & 1 \\
\hline 6 & CTC-SC1-3 & CTC & SC1 & 3 & $1 \%$ & 100 & 99 & 1 \\
\hline 7 & CTC-SC5-1 & CTC & SC5 & 1 & $5 \%$ & 100 & 95 & 5 \\
\hline 8 & CTC-SC5-2 & CTC & SC5 & 2 & $5 \%$ & 100 & 95 & 5 \\
\hline 9 & CTC-SC5-3 & CTC & SC5 & 3 & $5 \%$ & 100 & 95 & 5 \\
\hline 10 & CTC-SC10-1 & CTC & SC10 & 1 & $10 \%$ & 100 & 90 & 10 \\
\hline 11 & CTC-SC10-2 & CTC & SC10 & 2 & $10 \%$ & 100 & 90 & 10 \\
\hline 12 & CTC-SC10-3 & CTC & SC10 & 3 & $10 \%$ & 100 & 90 & 10 \\
\hline 14 & LA-SP-1 & LA & SP & 1 & $0 \%$ & 200 & 200 & 0 \\
\hline
\end{tabular}




\begin{tabular}{|r|l|l|l|r|r|r|r|r|}
15 & LA-SC1-1 & LA & SC1 & 1 & $1 \%$ & 200 & 198 & 2 \\
\hline 16 & LA-SC5-1 & LA & SC5 & 1 & $5 \%$ & 200 & 190 & 10 \\
\hline 17 & LA-SC10-1 & LA & SC10 & 1 & $10 \%$ & 200 & 180 & 20 \\
\hline
\end{tabular}

Tabela 38 - Amostras

\begin{tabular}{|lr}
\hline Ensaio & Soma de Composto (g) \\
\hline CTC & 48 \\
LA & 32 \\
\hline Total Geral & $\mathbf{8 0}$
\end{tabular}

Tabela 39 - Massa total de amostras por ensaio 